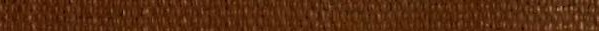
49

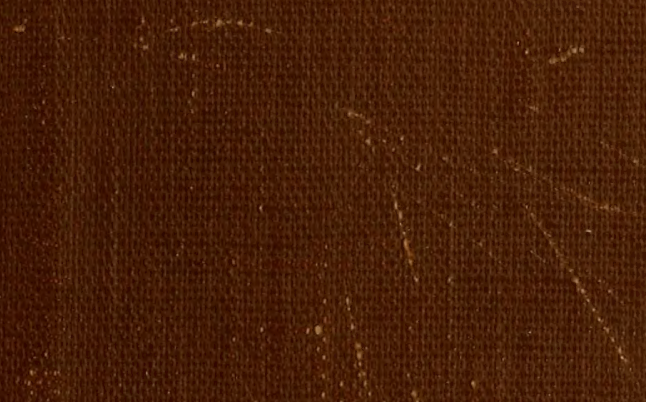











\section{$Q_{L}$ \\ 444 \\ A7K86 \\ Invertizool}

\section{$\frac{200062}{\text { Sinth somicin } 40}$}

\section{State of Connecticut}

State Geological and Natural History Survey

BULLETIN No. 26

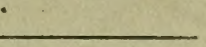

\section{THE}

\section{ARTHROSTRACA OF CONNECTICUT}

HARTFORD

Published by the State 1918

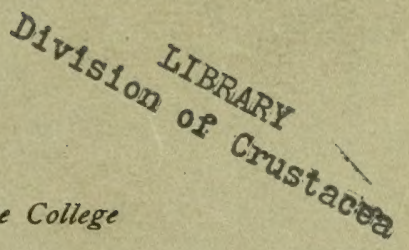

B. W. KUNKEL

Professor of Biology, Lafayette College

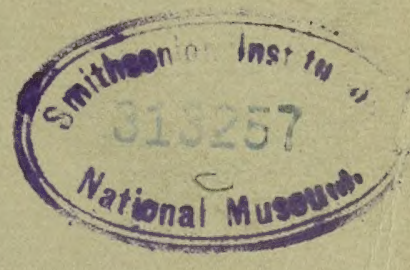

SMITHSONIAN

SEP 091986

LHARAFIES 



\section{BULLETINS}

OF THE

\section{State Geological and Natural History Survey of Connecticut.}

I. First Biennial Report of the Commissioners of the State Geological and Natural History Survey, 1903-1904.

2. A Preliminary Report on the Protozoa of the Fresh Waters of Connecticut: by Herbert William Conn. (Out of print. To be obtained only in Vol. I, including Bulletins I-5.)

3. A Preliminary Report on the Hymeniales of Connecticut: by Edward Albert White.

4. The Clays and Clay Industries of Connecticut: by Gerald 1 ncis Loughlin.

5. The Ustilagineæ, or Smuts, of Connecticut: by George Per:ins Clinton.

6. Manual of the Geology of Connecticut : by William North Rice and Herbert Ernest Gregory. (Out of print, except in bound volume.)

7. Preliminary Geological Map of Connecticut: by Herbert Ernest Gregory and Henry Hollister Robinson.

8. Bibliography of Connecticut Geology: by Herbert Ernest Gregory.

9. Second Biennial Report of the Commissioners of the State Geological and Natural History Survey, 1905-1906.

Io. A Preliminary Report on the Algæ of the Fresh Waters of Connecticut: by Herbert William Conn and Lucia Washburn (Hazen) Webster.

II. The Bryophytes of Connecticut: by Alexander William Evans and George Elwood Nichols.

12. Third Biennial Report of the Commissioners of the State Geological and Natural History Survey, 1907-1908.

13. The Lithology of Connecticut: by Joseph Barrell and Gerald Francis Loughlin. 



\section{CATALOGUE SLIPS.}

Connecticut. State geological and natural history surey. Bulletin no. 28. The Arthrostraca of Connecticut. By B. W. Kunkel. Hartford, 1918.

261 pp., 84 figs., $25^{\mathrm{cm}}$.

Bibliography, p. 258-261.

Kunkel, Beverly Waugh, $1881-$

The Arthrustraca of Connecticut. By B. W. Kunkel. Hartford, 1918.

261 pp., 84 figs., $25^{\mathrm{cm}}$.

Bibliography, p. 258-261. 



\section{CATALOGUE SLIPS.}

\section{Zoölogy.}

Kunkel, B. W. The Arthrostraca of Connecticut. Hartford, 1918.

261 pp., 84 figs., $25^{\mathrm{cm}}$.

(Bulletin no. 26, Connecticut geological and natural history survey.) Bibliography, p. 258-261.

\section{Crustacea.}

Kunkel, B. IV. The Arthrostraca of Connecticut. Hartford, 1918.

261 pp., 84 figs., $25^{\mathrm{cm}}$.

(Bulletin no. 26, Commecticut geological and natural history survey.)

Bibliography, p. 258-261. 



\section{State of Sonnectient \\ PUBLIC DOCUMENT No. 47}

\section{State Geological and Natural History Survey}

HERBERT E. GREGORY, SUPERINTENDENT

\section{Bulletin No. 26}

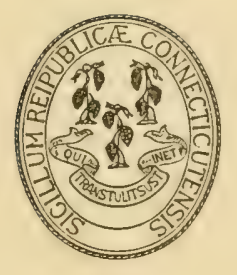

HARTFORD

Printed by the State Geological and Natural History Survey 


\title{
State Geological and Natural History Survey
}

\author{
COMMISSIONERS
}

Marcus H. Holcomb, Governor of Connecticut

Arthur Twining Hadley, President of Yale University

William Arnold Shanklin, President of Wesleyan University

Flavel Sweften Luther, President of Trinity College

Charles Lewis Beach, President of Connecticut Agricultural College

Frederick Henry Sykes. President of Connecticut College for Women

\author{
SUPERINTENDENT \\ HERBERT E. GREGORY
}




\title{
T H E
}

\section{ARTHROSTRACA OF CONNECTICUT}

\author{
$\mathrm{By}$ \\ B. W. KUNKEL \\ Professor of Biology, Lafayette College
}

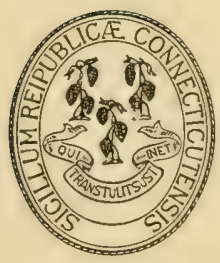

HARTFORD

Printed for the State Geological and Natural History Survey 1918 



\section{CONTENTS}

INTRODUCTION

Economic Importance

Classification of the Arthrostraca

PART 1. AMPHIPODA . . . . . . 15

Key to the Sub-orders of Amphipoda . . . 15

Anatomy . . . . . . . 15

General Form of Body and Telson . . . . 15

Appendages . . . . . . . . . 18

Antennæ . . . . . . . . 18

Mouth Parts $\quad$. $\quad$. $\quad$. $\quad$. $\quad$. 20

Gnathopods and Pereiopods . . . . . 23

Abdominal Appendages . . . . . 25

Sense Organs . . . . . . . . . 26

Internal Anatomy . . . . . . 27

Sexual Differences . $\quad . \quad$. $\quad . \quad$. 31

Size : . . . . . . . . . 32

Color . . . . . . . . . . 32

Habitat . . . . . . . . 33

Movements . . . t. . . . . 35

Food . . . . . . . . . . 37

Enemies . . . . . . . . . . 38

Resistance to Adverse Conditions . . . . . 38

Molting . . . . . . . . . 39

Nests and Nest-building . $\quad . \quad$. $\quad . \quad 39$

Breeding Habits . . . . . . . 40

List of Species $\quad . \quad$. $\quad . \quad \ldots \quad \ldots 43$

Hyperiidea . . . . . . . . 44

Gammaridea . : . . . . . . . 47

Key to the genera of Gammaridea - . . 47

Caprellidea . . . . . . . . 174

PART 2. ISOPODA

Key to the Sub-orders of Isopoda . 185

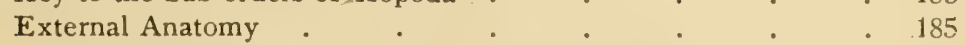

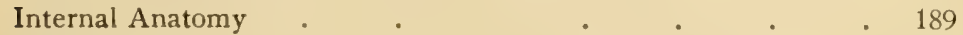

Biology $\quad . \quad$. $\quad . \quad$. $\quad . \quad 189$ 
List of Species .

Key to the Genera of Isopoda . . . . . 191

Tanaioidea or Chelifera . . . . . . . . 193

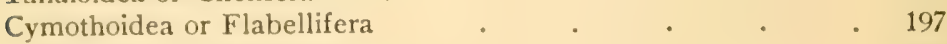

Idotheoidea or Valvifera . . . . . . . . 214

Aselloidea or Asellota $\quad$. . . . . . 230

Bopyroidea or Epicaridea . . . . . . . . $\quad$. 235

Oniscoidea . . . . . . . . . . 237

LIST OF FIGURES $\quad$. $\quad$. $\quad$. $\quad$. 255

BIBLIOGRAPHY . . . . . . . . 258 




\section{INTRODUCTION}

The purpose of this report is three-fold; first, to describe and figure as far as possible all the Arthrostraca which have been collected within the limits of the State of Connecticut; second, to describe briefly those forms which have been reported from neighboring States only, but whose habitat probably extends to this region; and third, to furnish to the general student an account of the anatomy and biology of the group as represented by species of this State. The Amphipoda will be treated more fully than the Isopoda because the latter group has already been discussed, in the excellent account of the Rev. T. R. R. Stebbing in his History of Crustacea (D. Appleton \& Co., I893) pp. $314-435$; in the briefer paper by Miss Richardson in the Proceedings of the United States National Museum, vol. 27, pp. I-3r, I905; and in Harger's valuable paper on the Marine Isopoda of New England in the Report of the United States Commissioner of Fisheries for 1878, pp. 297-462.

Among the works that have been consulted and have proven of greatest value in the preparation of this report, may be mentioned Della Valle's monograph on the Gammarini (Fauna und Flora des Golfes von Neapel, vol. 20, pp. I-296, I893) and Mayer's work on the Caprellidea (Ibid., vol. 6, pp. 84-184, I882, and vol. I7, pp. 94-144, I890.) These volumes contain very full accounts of the anatomy and biology of the groups as a whole. For the description of species, attention should be called to Stebbing's Gammaridea (Das Tierreich, Lief. 2I, pp. I-806, I906), which gives descriptions and determinative keys with full synonomy for all the Gammaridea described up to $\mathrm{I} 898$, and to G. O. Sars's Crustacea of Norway (vol. I, pp. I-7II, I890-1894), in which the descriptions are particularly accurate and the figures reliable. Without the help afforded by these figures the labor of preparing the ones for this report would have been vastly increased. The various publications of Holmes on the North American Amphipoda have also been freely re- 
sorted to as the numerous references will testify. The works of Miss Richardson, especially her monograph on the North American Isopoda (Bull. U. S. Nat. Mus., No. 54, I905), of Oscar Harger, and of G. O. Sars, have been very useful in the study of Isopoda. Besides these, the classic Vineyard Sound report by Verrill, Smith, and Harger (Rep. U. S. Com. Fish. for I871-2, pp. 295-747, I874) and a Biological Survey of the Waters of Woods Hole and Vicinity, by Sumner, Osburn, and Cole, (Bull. Bur. of Fish., vol. 3I, I9I3) have proven mines of information pertaining to the habits and natural history of the Arthrostraca of Connecticut.

The material upon which this report is based consists largely of the collections of Amphipoda and Isopoda made by the United States Fish Commission at Noank, Connecticut, in the summer of 1874 , and very kindly loaned by the Smithsonian Institution, and the extensive collections in Peabody Museum of Yale University, made mostly by Professors Verrill and Smith in the neighborhood of New Haven.

As might be expected, there are very few species from this State which have not already been reported. Holmes in his paper on the Amphipoda of Southern New England (Bull. U. S. Bur. Fish., vol. 24, pp. 457-529, 1905) and in his key to the Amphipoda of North America published in the American Naturalist, (vol. 37, pp. 267-292) has reported all the Amphipoda which have been found in Connecticut with the exception of Photis reinhardi Kröyer, and one species Tmetony.x quadratus which is here described and figured for the first time. Miss Richardson has included in her key to the Isopoda of North America (Amer. Nat., vol. 34, pp. $207-230$ and 295-309) all the species of Isopoda which we have met with in the present study.

Notwithstanding the fact that so few additions to the fauna of New England are made in this report, it is hoped that the publication of the figures of native forms, together with a general account of the anatomy and biology of the Arthrostraca, will stimulate interest in this group and be of service to students. 


\section{ECONOMIC IMPORTANCE.}

Except for a few species which destroy submerged timbers, the economic importance of the Arthrostraca is indefinite but probably great on account of their large numbers and their widely extended habitat. Many species perform an important service as scavengers by destroying decaying matter along the shore. According to Miss Richardson, certain parts of the coast of France, where shark-fishing is carried on extensively, would be almost uninhabitable were it not for the swarms of Isopoda which consume the heads of the sharks which are thrown back on the beach and which would otherwise become highly offensive. Naturalists in the Arctic regions, where the Amphipoda are especially numerous, obtain thoroughly cleaned skeletons of bears and other animals by exposing their bodies alongside of their boats to the shoals of small Amphipoda, which pick them absolutely clean. According to Mr. Geoffrey Smith in the Cambridge Natural History, Amphipoda, "when crowded sufficiently, will even attack living fishes, and by sheer press of numbers impede their escape and devour them alive." It is hardly possible, however, that any appreciable number of fish are so destroyed.

The Amphipod, Chelura terebrans, and the Isopod, Limnoria lignorum, often occurring together as well as with the "shipworm," Teredo, do great damage by destroying submerged timbers. Chelura is quite abundant on the European coast and has been reported from Bermuda, but on the Atlantic coast of New England it has been reported only from Woods Hole and Provincetown, Massachusetts. At the latter place, Professor Verrill found it from 8 to 12 feet below low water. (Smith, Proc. U. S. Nat. Mus., vol 2, p. 232, I879.)

Along the Connecticut shores Limnoria is the most important crustacean which destroys timbers. Verrill, in the Report on the Invertebrates of Vineyard Sound (p. 379), describes it as eating burrows into solid wood to the depth of about half an inch. These burrows may be so numerous that the outer layers of the timbers decay rapidly and are washed away readily by the waves, leaving a new surface which in turn is attacked by the crustacean. It works chiefly in the softer parts of the wood between the hard annual layers and avoids knots and those 
parts which are impregnated by iron rust from spikes, etc. When abundant it will destroy soft timber at the rate of half an inch a year, thus reducing the diameter of a pile, for example, by one inch in that time. On the average, however, the rate of destruction is only about half of this. As early as 1875 Andrews observed Limnoria attacking the gutta percha of submarine telegraph cables. (Quart. Jour. Micro. Sci., ser. 2, vol. 15, p. 332, I875.)

The holes made by this Isopod are nearly round and may be a sixteenth of an inch in diameter. They go into the wood at all angles and are usually more or less crooked. The species is confined to a rather narrow zone extending a short distance above and below low-water mark. The burrows are made by means of the stout mandibles and the excavated material is eaten; this the burrow affords the animal both food and shelter.

The remedies against this animal are chiefly copper, or other metallic sheathing, broad-headed iron nails driven close together, and coal tar, creosote, or copper paint applied to those parts which are liable to be attacked.

Certain of the terrestrial Isopoda also damage vegetation to some extent by feeding upon the more tender portions of plants. In Louisiana and Texas Armadillidium vulgare, according to Miss Richardson, is a menace to cucumbers and other plants grown in hot houses as well as to young cotton, and in Virginia it is "one of the most destructive pests with which the mushroom grower has to deal."

Besides the rôles already mentioned, the Arthrostraca are important as food for certain fishes, forming, with the shrimps, a very large part of the food of most of our more valuable edible fishes. Professor Verrill states that the Amplipoda occur in such immense numbers that they can nearly always be obtained by the fishes that eat them, and that the voracious blue fish feed upon them even when menhaden and other fishes which they prey upon are plentiful in the same neighborhood. Among the species of Amphipoda taken from the stomachs of porgies, tom cod, and herring caught at Woods Hole and New Haven, large numbers of Unciola irrorata, Ampelisca sp?, Gammarus anmulatus, G. locusta, Calliopius lariusculus, and Leptochcirus pinguis have been recorded by Verrill. 


\section{CLASSIFICATION OF THE ARTHROSTRACA.}

The Amphipoda and Isopoda together constitute the tribe or legion of the Malacostracous Crustacea known as the Arthrostraca. The Arthrostraca are characterized by the absence of a carapace, the head being fused with never more than one thoracic segment, the presence of only seven free thoracic segments, a single pair of maxillipeds, sessile eyes, and thoracic limbs which are uniramous throughout life. The two groups in question are sometimes referred to as the sessile-eyed Crustacea (Edriophthalma) to distinguish them from the other Malacostraca in which the eyes are mounted on movable stalks, the stalk-eyed Crustacea (Podophthalma).

The Amphipoda may be defined as Arthrostraca in which the body is generally strongly compressed from side to side; and with the abdomen consisting typically of six segments and a telson. The gills are borne on the inner side of the proximal joints of the thoracic legs, and, corresponding to the position of the gills, the heart lies in the anterior part of the body.

The Isopoda may be defined as Arthrostraca in which the body is generally strongly flattened dorso-ventrally; with the abdomen composed of six segments, which may be partly or wholly fused together, and the terminal one which is referred to as the telson and is large and shield-like but rarely free; the respiratory organs are borne on abdominal segments and consequently the heart has an abdominal position.

The most important characteristics which distinguish the two groups are: (I) The general form of the body which is flattened in the Isopoda, and compressed laterally in the Amphipoda; and (2) the respiratory organs, which are usually modified pleopods in the Isopoda, and always appendages of the thoracic limbs in the Amphipoda. In the former group the five anterior abdominal appendages are usually broad plates which are all more or less similar in shape and size. In the Amphipoda the first three pairs are similar, being long, narrow appendages adapted for swimming while the last three pairs are short and stiff and are adapted for leaping.

The classification of the Amphipoda into families is not in an entirely satisfactory condition. The group is very diversified and there is a great difference of opinion regarding its proper 
subdivision. Della Valle groups all the Gammaridea into only ten families. Sars recognizes twenty-five families in the Norwegian fauna alone; Stebbing in the "Challenger" Report divided the Gammaridea into twenty-six families and in his later work on the Gammaridea, I906, he recognizes forty-one families.

I have followed pretty closely Stebbing's later classification in this paper and have attempted no revision of the group whatever. 


\section{PART I. AMPHIPODA.}

\section{KEY TO THE SUBORDERS OF AMPHIPODA.}

The Amphipoda are divided into three suborders which may be readily distinguished from each other.

A. Eyes large, covering nearly the whole side of the head; uropods usually with laminate rami which form a tail fan with

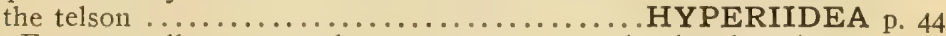
AA. Eyes usually present but never enormously developed.

B. Abdomen well developed...............GAMMARIDEA p. 47 $B B$. Abdomen rudimentary; body extremely slender

CAPRELLIDEA p. I74

\section{ANATOMY \\ GENERAL FORM OF BODY AND TELSON}

In all the Amphipoda except the Caprellidea, the general aspect of the body is quite uniform, being slender and slightly tapering at each end and usually compressed laterally. In only a few genera, such as Corophium, Siphonacetes, Unciola, and Chelura, is the body cylindrical or depressed. The Lysianassidæ and Ampeliscidæ are the most compressed forms. The Caprellidea are slender and threadlike.

The body is divided into three regions: the head or cephalon, the thorax, and the abdomen. The head never exhibits its segmental structure and the number of segments represented in this region is still in question; it is probably seven. The thorax is made up of seven segments, and the abdomen of six, exclusive of the telson, which is probably not of the nature of a regular segment of the body. The abdomen always is made up of three freely articulating segments anteriorly, followed by three which are never very movable and may suffer more or less fusion; thus the fourth and fifth segments are fused in Dexamine and Ampelisca and the fourth, fifth, and sixth are consolidated in Chelura terebrans. This fusion, however, is of no great systematic value, since in different species of the genus Corophium, for example, the last three segments may be either fused or all distinct. In the Caprellidea the abdomen is very rudimentary and is generally devoid of any indication of segmentation. 
The head is always quite free from the thorax except in the Caprellidea, where it is fused with the first thoracic segment. It is largest in relation to the rest of the body in the Hyperiidea and smallest in the Caprellidea; it is always longer than the first segment of the thorax in the Gammaridea.

The anterior margin of the head may be prolonged in front to form a rostrum between the bases of the first antennz. Usually the rostrum is an inconspicuous, pointed process, but in some genera it may form a hoodlike projection over the basal joints of the antenne as in Harpinia, Phoxocephalus, and Paraphorus. In Siphonacetes the rostrum is spiniform; in Dexamine and Epimeria it is curved ventrally. In the Ampeliscide the first antenne are so closely appressed that the rostrum is wanting.

The anterior margin of the head between the bases of the first and second antennæe projects forward as the interantennal lobe, which is usually semicircular but may be acutely pointed or variously modified. In Haustorius, Sympleustes, and Dexaminc, the interantennal lobes are acute. The Ampeliscidxe are peculiar in the great distance that separates the first and second pairs of antennxe and the almost complete disappearance of an excavation in which the latter articulate. Usually the second antenne are joined to the head only slightly posterior to the first pair; lut in those forms in which the second antenna are more or less pediform, the front margin of the head may be deeply excavated as in Ischyrocerus, Jassa, Ericthonius, Corophium, and Unciola.

Eyes are tisually present and compound. In a few species they may be lacking, as in Harpinia plumosa and Stegoceplualus inflatus, or imperfectly developed, as in Phorocephalus holbölli and IIaustorius arcnarius. In most of the Cedicerida the eyes are situated so far dorsally that they are almost in contact with each other. The Hyperiidea have very large eyes that cover the whole side of the head, but in the Gammaridea the eyes are never very enormously developed. It is only in the Ampeliscidre that we find the one pair of compound eyes generally present in the Amphipoda replaced by two pairs of eyes provided with simple corneal lenses. 
The segments of the thorax increase gradually in length from the anterior end to the posterior, except in Harpinia, where the last segment of the thorax is shorter than the preceding on account of the reduction of the last pair of thoracic legs. Although typically the dorsal region of the thoracic segments is smooth and evenly rounded, in a few cases it may be produced to form a keel as in Epimeria and Paramphithoe.

The first three segments of the abdomen are always in the Gammaridea deeper than those of the thorax and have the lateral margins prolonged downwards to form pleura; the last three segments are small and do not have pleura. The dorsal region of the abdominal segments, like the thoracic, is usually evenly rounded, but more frequently than in the thoracic segments, it may exhibit a keel or crest as in Apherusa gracilis. In Ampelisca spinipes and Byblis serrata the fourth segment bears a prominent keel which ends abruptly posteriorly. The first four segments of Calliopius laviusculus are quite characteristically raised posteriorly to form rounded keels, while in Dexamine thea, these segments are prolonged posteriorly to form sharp, spiniform projections, and in Carinogammarus the first three segments only are similarly produced. Many of the Lysianassidæ and Ampeliscidæ exhibit a depression on the dorsal side of the fourth abdominal segment which is more pronounced in the male than in the female. In Chelura terebrans, the third abdominal segment bears a long curved process which extends posteriorly. The posterior margins of the three posterior segments may be armed with fascicles of spines, as in Carinogammarus and Gammarus, or produced to form small spiniform projections, as in Mara and Melita dentata, or the spines may be confined to the fourth and fifth segments, as in Leptocheirus pinguis.

The postero-lateral angles of the first three abdominal segments are usually evenly rounded but the third is especially modified frequently. Thus in Ampelisca macrocephala, Unciola irrorata, Sympleustes glaber, and Harpinia plumosa, it bears an acute, slightly upturned projection, above which is a rounded sinus, which in some cases may be followed by a rounded lobe. In a few species the postero-lateral margins of the third abdominal segment may be serrated, as in Batea secunda; or the second and third may both be so adorned, as in Apherusa gracilis. 
The telson has been regarded by some as representing the last segment of the abdomen, but Della Valle and others regard it as simply a development of the posterior end of the rectum, in the nature of an anal valve, morphologically equivalent to the upper lip which will be described below. The telson may have the form of simply a thin oval projection as in Lystanopsis and Calliopius. In Amphithoc, Grubia, Sympleustes, and Unciola it is also a simple plate but somewhat thicker than in the preceding genera. In Microdeutopus the rectum passes directly through the telson, which is undivided. The telson may be more or less deeply divided into two lobes as seen best in the Gammaridæ where the lobes are usually rather widely separated from each other and armed apically with a fascicle of spines.

\section{APPENDAGES.}

Each segment of the crustacean body normally bears a single pair of appendages upon the ventral side so that in those forms in which two or more segments are fused together the number of appendages affords a criterion of the fundamental segmentatior. In the head region of the Amphipoda, however, the difficulty of determining the number of true segments lies in the fact that an uncertainty exists regarding the homologies of some of the appendages. According to most students of the group, the head is made up of seven segments which bear the following appendages from in front backwards: eyes, first or superior antennx, second or inferior antennæ, mandibles, first and second maxillæ, and maxillipeds. The last are regarded as homologucs of the first maxillipeds of the Decapoda, and as such are fundamentally appendages of the thorax and not of the head.

The mouth parts form the buccal mass projecting from the ventral side of the anterior end of the head. The buccal mass is especially prominent in the Orchestiidea (Fig. I). In the Caprellidea the first gnathopod, owing to the fusion of the first segment of the thorax with the head, appears to articulate with the head and to be associated with the mouth parts.

\section{Antennce.}

The antennix may be very long, as in the males of many Ediceridx, Phoxidæe, and Lysianassidæ in which they surpass 


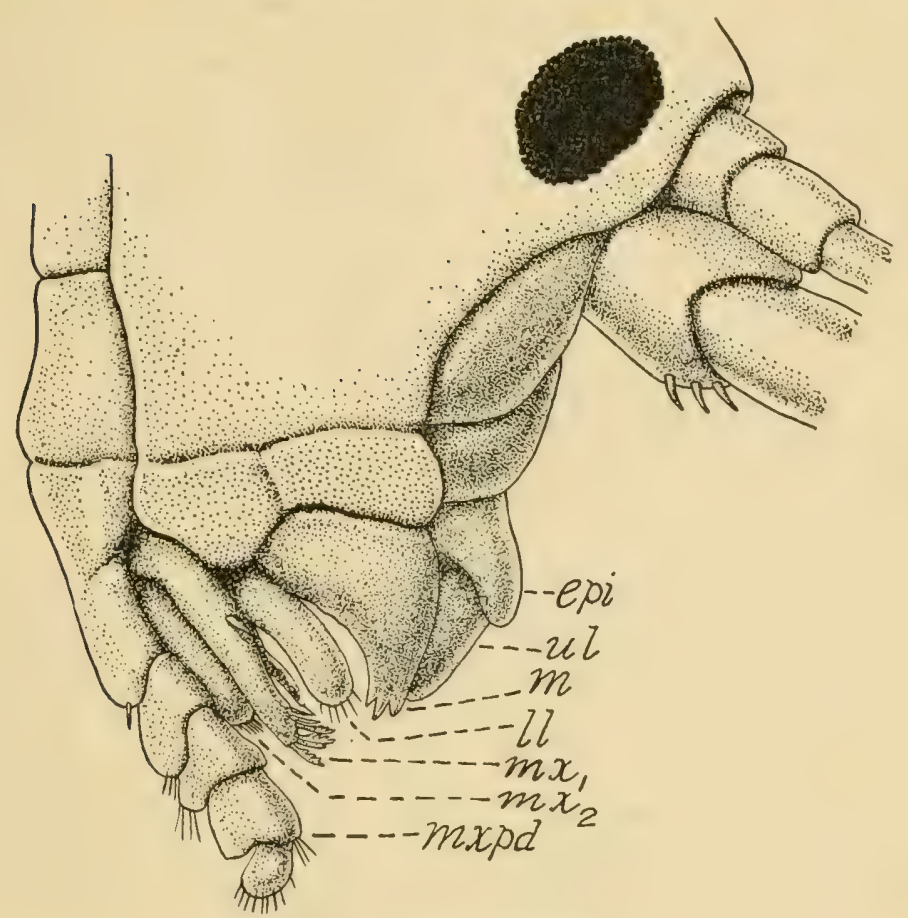

FIG. I. Orchestia agilis.

the body in length; or they may be short as in Orchomenella. The first antennæ only may be extremely short, as in Orchestia and the females of the Hyperiidea. The second antennæ are usually more constant in their size but they too suffer considerable reduction in female Hyperiidea and may be very large as in Corophium and Siphonocetes.

The first antennæ are made up of a peduncle of three segments, followed by a flagellum usually multiarticulate, and sometimes also by a secondary or accessory flagellum. The first joint of the peduncle is characteristically very stout in the Lysianassida. The flagellum may be very short as in Orchestia. The accessory flagellum is lacking in the Ampeliscidx, Orchestiidæ, Stenothoe, Sympleustes, Calliopius, Pontogeneia, Dexamine, Batea, Amphithoe, Ericthonius, Corophium, Siphonocetes, and Podoceropsis. In some few genera like Grubia and Jassa, it is quite rudimentary and may easily be overlooked. Particular attention is 
called to Calliopius laviusculus, in which the process on the distal end of the last segment of the peduncle of the first antennx may be erroneously regarded as an accessory flagellum.

In the Caprellidea the number of segments in the flagellum increases regularly with age, and a secondary flagellum is never present.

The second antennæe consist of a peduncle of five joints and a flagellum which is usually multiarticulate. An accessory flagellum is never present. Of the peduncular joints only the last two are well developed, the first two are always very short and the first is fused with the head. In the Orchestiidx the second joint is likewise fused with the head (Fig. I). The second joint is characterized by the fact that the antennal gland, probably excretory in function, opens by means of a hollow conical process on its lower side. This gland cone is conspicuous in Mclita and is very minute in Orchestia. In some species the second antennæ exhibit marked sexual differences. In Corophinm the peduncle of the male is much stouter and armed with spiniform processes; in the Lysianassidæ the whole antenua is much longer than in the female, and in Ampelisca the male has a row of tufts of specialized sensitive hairs on the dorsal margin of the peduncle of the second antennæ as well as on the ventral margin of the first. The flagellum may be reduced to a rudiment made up of only two or three segments, as in Corophium and Siphonxcetes, or may be very long and slender, as in the males of the CEdiceridæ and Lysianassidæ, and Phoxus. In the Caprellidea of the New England coast, the flagellum is never more than biarticulate.

Both antenne may be provided with very curious, slipper- or wineglass-shaped appendages known as calceoli, which probably are sensory in nature. These are disposed along one margin of the peduncles or at the distal ends of the flagellar segments. They are seen in Calliopius, Pontogencia, and the males of the Ampeliscidæ.

\section{Mouth Parts.}

The mouth parts lie partly concealed by the projecting coxal plates of the first gnathopods. As viewed from the side, however, the mandibular palps and the maxillipeds extend forward beyond the general outline of the mass. The mandibular palp is directed 
forward and usually upward between the bases of the antennæ, while that of the maxillipeds extends downward and forward, with the terminal joint bent somewhat toward the middle line.

The mouth is bounded above by the upper lip, which is a broad plate, circular or oval in outline and continuous by its front margin with the epistome. The epistome forms the anterior, ventral surface of the head. The upper lip may form a kind of rostrum projecting forward as in Ericthonius or it may be small and vertical in position as in the Lysianassidx.

The mandibles bound the mouth laterally and form the principal chewing organs, being admirably adapted for tearing and cutting by their strength and heavy calcification. In general the mandibles are triangular in shape with the anterior margins inclined toward the middle line, and, except in the Lysianassidre, bear several strong tooth-like processes. Behind this principal incisive plate, or cutting edge, there is often a secondary one movably articulating with it, which is weaker in structure, but likewise usually denticulated. Posterior to the cutting edges, the mandibles generally bear a molar tubercle having the form of a cylinder or truncated cone, which is directed internally and backward, and is armed distally with rasp-like teeth. The tubercle is absent in the Lysianassidx. There may also be present a palp, consisting of never more than three joints, which is inserted towards the middle of the anterior surface. In the Orchestiidæ, Dexamine, Stenothoe, and Caprella, the palp is lacking; in Siphonacetes it is uniarticulate; and in Corophium it is made up of two joints. In species having a triarticulate palp the first joint is always short, except in the Hyperiidea, where it may be somewhat elongated, but is never as long as the last two joints. The terminal joint may be somewhat spatulate as in Ericthonius but more generally it tapers to a slender point as in Gammarus locusta and Elasmopus.

The lower lip is inserted immediately beneath the mouth, and is made up of two halves which are united on the middle line for a greater or less distance from the posterior end. Each plate has a regular anterior margin of semicircular form except in the genera Amphithoe and Grubia, in which there is a deep, rounded sinus, making the plate bilobed. The postero-lateral angles are always more or less prolonged to form the maxillary 
processes. Posterior to the principal lamina there is a smaller accessory one of oval form with its anterior margin entire.

The upper and lower lips are regarded as derived from folds of the extreme anterior end of the esophagus and not as truc appendages. Hence they are not referred to definite segments of the head.

The marille differ from the mandibles in their laminar form. The first maxille are more robust than the second and are provided with spines for tearing the food. The first pair are made up of an inner and an outer plate and a palp. The palp never has more than two joints, of which the first is shorter than the second. The inner plate may be almost obsolete as in Corophimm and Siphonacetes, or large and oval and furnished distally and medially with plumose spines, as in the Gammaridæ. In the Orchestiidxe, the inner plate is long and slender and armed distally with two plumose spines. The inner plate is lacking completely in the Caprellidea and Hyperiidea. The outer plate is always larger than the inner. Its distal margin is armed with a row of short spines of characteristic antler-like or comblike form which are masticatory in function. The palp articulates with the outer plate and its apex usually projects beyond the end of the outer plate. The palp is lacking in Orchestia and is rudimentary in Hyalc. In Deramine and Phorocephalus it is of a single joint. The free distal margin is sometimes furnished with setules, but more often it bears stout spines or is serrated. The second maxillie are always small and flexible. They are made np of an onter and an inner plate which bear setre on the inner and distal margins.

The marillipeds belong morphologically to the thorax, but are discussed here, as is nsual, in connection with the appendages of the head. The maxillipeds consist of an inner plate, outer plate, and palp. The appendages of the two sides are fused together on the middle line by the proximal joint. The inner plates are formed by an anterior and median expansion of the second joint, and the onter plates by a similar expansion of the third joint; the palp is made un of the remaining joints which may be as many as four. In the Hyperiidea the second segments are fused together completely on the middle line and palps are wanting; in the Caprellidea the fusion of the inner plates is 
partial; but in all other Amphipoda the plates are separate and palps are present. The plates are most highly developed in the Lysianassidx. They are obsolete in Stenothoe. The inner plates usually bear numerous setæ on their inner margins and may bear tooth-like spines apically which are of use in mastication. The outer plate is usually furnished with strong spines and setæ on the inner and distal margins. In Amphithoe and Grubia the sickle-shaped spines on the inner margin gradually increase in length toward the apex and become simple slender setæ. The first joint of the palp is always short; the second joint is usually cylindrical, but in Orchestia it bears a distal laminar prolongation resembling the inner and outer plates; the third joint is clubshaped or ovoid; and the fourth joint is somewhat conical and may be armed with a stout spine distally. In the genera Haustorius, Orchestia, and Taloricstia the palp is triarticulate, but in all other genera, when present, it is four-jointed.

\section{Gnathopods and Pereiopods.}

In all the Amphipoda there are seven pairs of thoracic appendages, except in the Caprellidea, in the New England species of which all traces of limbs of the third and fourth thoracic segments are wanting. The first two pairs differ greatly from the others and are generally referred to as gnathopods; so that the third thoracic limb becomes the first pereiopod. Each thoracic appendage is made up of seven joints which, reckoning from the proximal one, are designated usually as the coxal plate or coxa, basal joint, or basus, ischium, merus, carpus, propodus, and dactyl. In Haustorius the dactyls are wanting in the case of the pereiopods, although present in the gnathopods. Batca is unique in that the first gnathopod is reduced to a mere rudiment repre. senting the coxal plate and basal joint.

The first two pairs of pereiopods, like the gnathopods, are usually held flexed forward quite strongly at the joint between the ischium and merus, and the dactyls are directed backwards. They are usually of similar form and size and have slender basal joints. The third, fourth, and fifth pereiopods are more or less flexed backward at the joint between the ischium and merus and the dactyls are directed forwards. The basal joints of the last three legs are typically expanded to form flat plates. 
The joints are all movable in a fore and aft direction, except the first or coxal plate, which is attached to the thorax in such a way as to be capable of a slight lateral movement only, and from the median side of which the succeeding joint of the pereiopod arises. The ischium is always short, scarcely longer than broad except in the second gnathopods of the Lysianassidx. The succeeding joints vary greatly in different species in both their shape and size; the terminal one, however, is usually claw-like.

The coxal plates vary greatly in depth and length both among themselves and in different species. They are very deep, for example in Stenothoe, Metopa, Stegocephahis, and the Lysianassidre, while in the Corophiidæe they are small and low, not forming a continuous series of overlapping plates as is more common. There is a gradual increase in size from the first to the fourth, which is generally the largest. The fourth may be excavated at the upper posterior angle to accommodate the coxal plate of the fifth pereiopod, but in the following families it is not excavated: Stenothoidx, Aoridx, Photidx, Amphithoidæ, Jassidæ, and Corophiidie. The fifth, sixth, and seventh coxal plates are often considerably smaller than the preceding, diminishing posteriorly, and are bilobed. Among the Caprellidea the coxal plates are often absent and when present are extremely minute.

The gnathopods exhibit great differences in individual species as well as in the two sexes and at different ages. The first pair is smaller than the second except in the genera, Ampclisca, Microdeutopus, Lembos, Unciola, and Leptocheirus, where the condition is reversed. The propodus is usually subchelate; that is, the posterior and distal margins form a palm against which the dactyl strikes when flexed, so that the appendage is adapted for grasping. The angle made by the posterior margin and the palm is known as the prehensile angle and may be armed with one or more stout spines. The dactyl may have its concave margin modificd by serrations or processes. In a few species the dactyl does not close against the propodus, in which event the gnathopod is known as simple. This is more frequently the case with the first pair than with the second. Thus in Lysianopsis alba, Leptocherius pinguis, and the females of Talorchestia, the first gnathopod is simple, and in Ampelisca spinipes, the second is simple. Besides the simple and subchelate forms of 
these appendages, there may also be the chelate type, in which the propodus is prolonged at the posterior margin distally so that the dactyl strikes against the anterior margin of this, as in the pincers of the lobster or crayfish. The second gnathopod is chelate in Lysianassa and in the females of Talorchestia and Orchestia. In a few species the gnathopods are found to be complexly subchelate, in that a process of the carpus becomes involved in grasping. Thus in Microdeutopus, the first gnathopod of the male, and in Ericthonius and Cerapus, the second pair is complexly subchelate. Among the Caprellidea the second gnathopods are, as a rule, inserted near the front margin, or at least in front of the middle of their segment, although in the male Caprella the insertion is very near the middle.

In a number of families the first and second pereiopods possess peculiar glands situated for the most part in the basal joints, but often extending into the distal joints as well, and opening to the exterior at the apex of the dactyl, which is then slightly truncate, or at a point just proximal to the tip. Such forms as Ampclisca, Microdeutopus, the Amphithoidæ, Jassidæ, and Corophiidæ, secrete by means of these glands a sticky substance which hardens quickly to form a thread. By means of this secretion a tube is formed for concealment as will be described below (p. 39).

In the native Caprellidea the first and second pereiopods are entirely wanting, but the three posterior pairs are well developed and subchelate. They increase in size from the anterior pair to the posterior.

\section{Abdominal Appendages.}

The abdomen bears two quite distinct types of appendages, and for this reason is frequently differentiated into an anterior pleon of three segments and a posterior urosome. Each segment of the pleon bears a pair of pleopods adapted for swimming, each of which consists of an unjointed basal joint or peduncle with two flexible, multiarticulate rami distally. These are provided marginally with long plumose setæ. The two peduncles are held together by a series of hooks, called coupling spines, which are situated near the distal end. In Corophium the peduncle is broadly. expanded medially but in other forms it is more nearly cylindrical in form. 
There are usually three pairs of uropods present. These appendages are never very movable and are always directed posteriorly, and are closely approximated. Like the pleopods they are made up of an unjointed peduncle and two rami, although in the Orchestiidxe, and in the genera Unciola, Stenothoe, Siphonacetes. Corophium, and Ericthonius; the terminal pair is uniramous. The rami are usually uniarticulate although the outer one may exhibit also a small terminal joint. The terminal uropods often differ greatly from the preceding pairs in size and form. In Ampelisca and the Gammaridx they project considerably beyond the others. In Melita the inner ramus is reduced to a mere scale-like rudiment while the outer one is biarticulate. Usually both the peduncle and the rami bear strong spines along the upper margin and at the tip. In Leptocheirus, Microdeutopus, and Grubia, the peduncle is prolonged beneath the attachment of the rami to form a long, slightly upturned, spiniform process. In Unciola the peduncle is produced into a lobe as long as the single ramus.

The rami may be lanceolate or flattened, as is seen best in the Gammaride, or they may be cylindrical or conical with recurved spines at the apex, as in Jassa, Ischyrocerus, Grubia, and Amphithoc.

In Chelura the uropods are highly specialized. The first pair are of the typical form, but the second pair lie well on the dorsal side of the abdomen; the peduncle bears a very large plate-like cxpansion medially and the rami are scarcely longer than wide; the terminal uropods are very large, with the outer ramus extremely long, cspecially in the male, and the inner ramus minute.

Owing to the extremely rudimentary condition of the abdomen in the Capreilidea, the appendages are greatly reduced. In Finella the first pair of appendages are liarticulate and the second pair are uniarticulate. In Caprella the males have a biarticulate pair in front and a thick uniarticulate pair behind. In the females the limb-like (first) pair are reduced to simple eminences bearing a few setæ.

\section{SENSE ORGANS.}

Besides the eyes, which have already been discussed, the sense organs of the Amphipoda consist of various filiform and special- 
ized processes of the integument, whose exact functions are still largely conjectural. When a foreign chemical substance is placed in a vessel containing Amphipoda, the antennæ are waved vigorously, which may point towards the conclusion that on these appendages are smelling or tasting organs. The delicate threadlike setæ noted frequently on the principal flagellum of the first pair of antennæ are called olfactory hairs. The calceoli, which occur in forms like Calliopius, are conical vesicles attached by their apices to the general surface of the skin. They have been called by Leydig "slipper-shaped" structures, but with greater propriety they might be compared to wine glasses. Their function is wholly unknown.

\section{INTERNAL ANATOMY.}

The nervous system consists of two symmetrical ganglionic chains, united at intervals by commissures, and lying on the

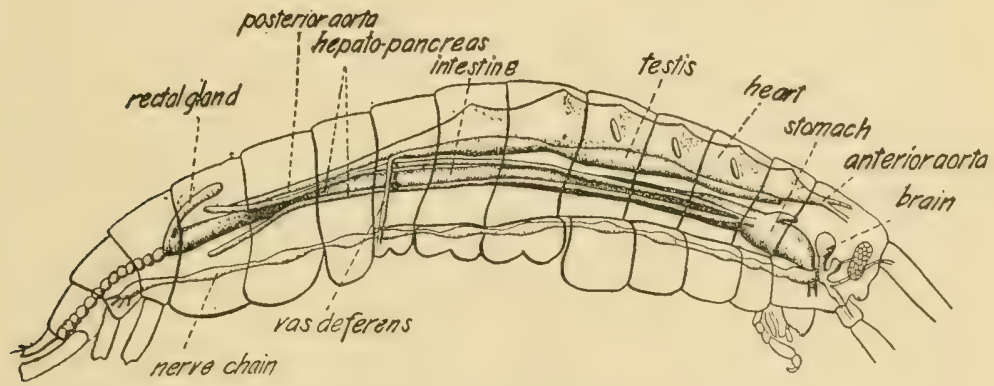

FIG, 2. Internal Anatomy, after Stebbing.

ventral side of the alimentary canal, except at the extreme anterior end, where the ganglia are on the dorsal side (Fig. 2). The supraesophageal mass is made up of two halves, separated by a deep median groove, and consists of two large cerebral lobes, as well as a pair of ganglia, which give rise to the optic nerves, and another pair giving rise to the antennal nerves. Beneath the esophagus and connected with the brain by commissures around it, lies the subesophageal mass, which gives off nerves to the mouth parts, and represents the consolidated ganglia of the segments to which the mouth parts belong. The subesophageal ganglia are continuous posteriorly with the subintestinal ganglionic chain. This consists of a pair of ganglia, 
fused together in the middle line, for each body segment except the last three, in which the ganglia are fused to a single mass. In the Caprellidea the ganglia of all the abdominal segments are fused together.

The alimentary canal consists of a straight tube of uniform diameter, except in the anterior portion, where it is dilated to form the stomach. The latter opens anteriorly by a narrow esophagus, which is curved ventrally. The mouth is bounded above and below by the upper and lower lips. The stomach is ovoidal in form and of very complicated structure. As in all the Malacostraca, a gastric mill is present which includes both a grinding and a straining mechanism. The midgut extends from the posterior end of the stomach to the last thoracic segment. Extending forward on the dorsal side of the stomach from the anterior end of the intestine is a so-called pyloric cæecum which is single in the Gammaridea but double in the other groups of Amphipoda. Arising likewise from just behind the stomach are the hepato-pancreatic creca which extend to a considerable distance posteriorly, lateral and ventral to the intestine. Typically there are four of these tubes present, but in Corophinm and Siphonacctes a single pair is present. In addition to these cæca there is also a "rectal gland," of creal form, extending forward and dorsally from the anterior end of the hind gut. This rectal gland probably corresponds to the Malpighian tubules of insects and functions as an excretory organ, according to IV. B. Spencer (Quar. Jour. Micro. Sci., ser. 2, vol. 25, pp. I83-I9I, I885). It is confined in most Gammaridea to the last three aldominal segments. The intestine opens to the exterior through the anus which lies just helow the telson except in the Photidxe, in which the telson is hollow and is traversed by the posterior end of the hind gut.

The circulatory system consists of a heart, arteries, and lacunce or sinuses. The heart is tubular in form, open at both ends, and situisted in the dorsal part of the thorax immediateiy beneath the integument, and extending as far back as the sixtl: thoracic segment. On the lateral sides of the organ are thrce pairs of openings, called ostia, which are oblique slits, guarded by valves which open inward. In the Hyperiidea there are two pairs of ostia usually and in Corophinm the number is reduced 
to a single pair corresponding in position to the last one of other forms. The arteries are reduced to an anterior and a posterior aorta, the openings into which from the heart are guarded by valves opening outward. The posterior aorta lies close against the intestine; the anterior one breaks up principally about the nervous matter of the head. The principal lacunæe are the pericardium and the ventral lacuna; they have no walls of their own but are simply the spaces between other organs through which the blood courses somewhat irregularly.

Internally the Amphipoda and Isopoda differ most strikingly as regards the circulatory system. In the latter group the heart lies principally in the abdomen and ends blindly behind. Besiles the anterior aorta, like that of the Amphipoda, there are five pairs of arteries extending forwards. On the ventral side of the body is a large blood sinus which is paired in the thorax but single in the abdomen. Five pairs of veins convey blood from the pleopods, which are respiratory in function in the Isopoda, to the pericardial lacuna. In the Isopoda the arterial system is much more complete than in the Amphipoda, where the lacuna are relatively more extensive. There is accordingly a more perfect separation of arterial and venous blood in the Isopoda.

The rapidity of the pulsations of the heart is considerable. Ir. young specimens of Microdeutopus Della Valle found the rate to be two hundred per minute.

Closely associated with the difference in the position of the heart in the Amphipoda and Isopoda is that of the respiratrry organs. In the former group the gills have the form of flattened oval sacs, depending from the upper posterior corner of the coxal plates, internal to the principal axis of the limbs. (Figs. 3 and 26.) The gills are confined to the last six thoracic appendages. In a few genera the last pair of pereiopods also lack gills.

In Ampelisca and Corophium the second gnathopods, of the females only, are devoid of these appendages and in Ericthonius and Cerapus this gill is absent in both sexes. The gills are exceedingly large in Gammarus, but in Orchestia they are very much reduced, in accordance with the semiterrestrial habit of the genus, and are twisted on their long axes instead of being flat plates parallel to the coxal plates. The anterior gills are usually larger than the posterior ones. 


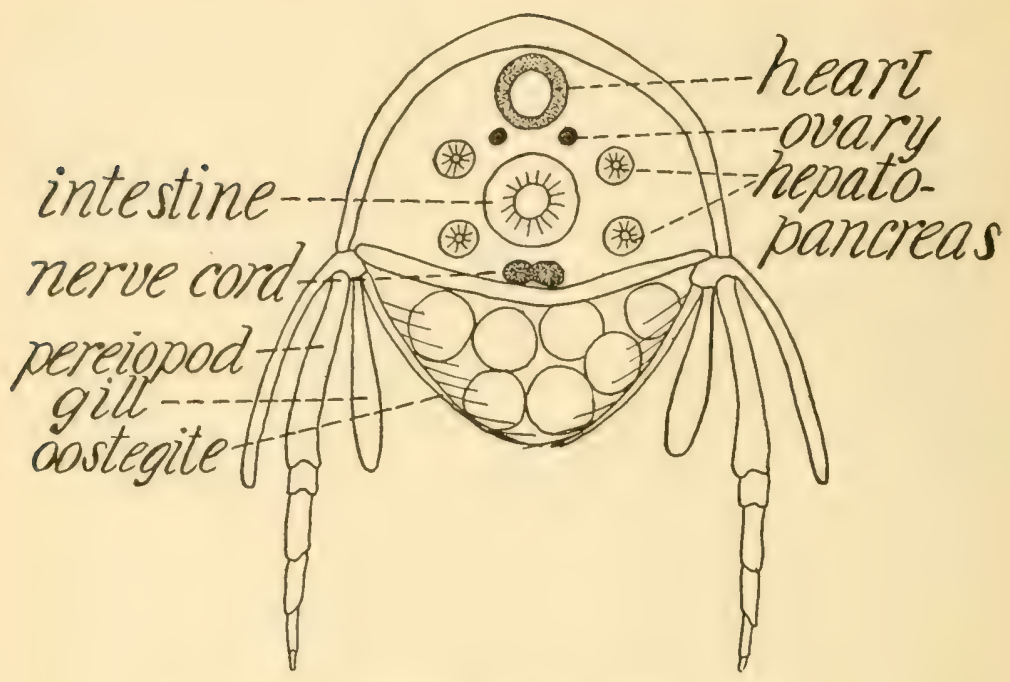

FIG. 3. Cross section through a female Amphipod.

'The testes are small, slender, fusiform, paired organs which lie directly below the heart and dorsal to the intestine. These organs taper posteriorly to two delicate tubes, the ejaculatory ducts, or vasa deferentia, which open by papillæ on the ventral side of the last thoracic segment. In the breeding season these papillæe enlarge considerably to form copulatory organs (Fig. 3I). The glandular portion of the testes usually lies behind the second and in front of the fifth segment of the thorax. Its anterior end is very attenuated and serves as a kind of ligament to hold the organ in place.

In the female the ovaries have the same position as the testes in the male but are somewhat longer. In form the ovary is irregularly cylindrical and when ripe may be more or less inflated. The oviduct opens from the lower outer surface of the ovary at a. point corresponding to the fifth thoracic segment and continues as a simple straight tube to the exterior at the base of the fifth coxal plate.

Usually there are four pairs of marsupial plates or oöstegites borne on the second, third, fourth, and fifth thoracic legs, but in some species there are six pairs attached to the last six legs, and in the Caprellidea there are only two pairs, belonging to the 
third and fourth segments. They are inserted on the inner surface of the coxal plates except in the Caprellidea and Phronimidæ where the attachment is directly to the ventral wall of the thorax. The insertion is nearer the middle line than the gills, so that when the brood pouch is filled with eggs the gills remain free to oscillate and receive fresh water.

In form these plates are rather long, tongue-shaped plates the margins of which are always provided with numerous long, slender prolongations like exceedingly flexible setæ. These prolongations intertwine with each other so that the lamellæ form a kind of basket which receives the eggs from the oviducts.

\section{SEXUAL DIFFERENCES.}

The sexes of the Amphipoda are always separate. Usually they are readily distinguished by the large marsupial plates, or oöstegites, of the females which support and protect the eggs and immature young. Besides this difference in the two sexes, the males are usually larger than the females and are provided with more sensory spines and setæ. It is in the form of the second antennæ and gnathopods, however, that the secondary sexual characters are most conspicuous. In striking contrast to the general rule that the second antennæ of the males bear more setæ than those of the females is the case of Corophimm, in which the second antenna of the male have none on the peduncle while those of the female have many. On the first antennæ of Ampelisca and the Lysianassidæ, calceoli are present in the males but not in the females.

The first gnathopods of Orchestia, Cerapus, and Microdeutopus are of vastly different form in the male and female, as may be seen by reference to the descriptions of the forms in question. In other genera, like Amphithoe, Hyale, and Gammarus, for example, the sexual differences in the first gnathopods are insignificant.

The second gnathopods are strikingly different in the two sexes in Talorchestia, Orchestia, Metopa, Elasmopus, Amphithoe longimana, Jassa, Ischyrocerus, and Ericthonius.

In Chelura terebrans, the second and third uropods are quite distinct in form in the two sexes; the second pair is provicled with long setæ in the male which are lacking in the female; the 
third pair has a foliaceous outer ramus in the female, and a much larger styliform one in the male. In this species, there is great difference between the male and the female in the length of a long styliform process extending backwards from the mid-dorsal line of the third abdominal segment.

The secondary sexual characters are not acquired completely until maturity is reached. The female form may be looked upon as the more primitive, for the young, when first escaped from the egg, generally resemble the female rather than the male. In examining a large number of specimens of Orchestia agilis from Woods Hole it was found that all individuals up to about $7 \mathrm{~mm}$. in length have gnathopods like the female, and in two or three individuals about $7.5 \mathrm{~mm}$. long the first gnathopods were of the male form, and the second pair, of the female. The gnathopods were of exactly the same form as those of the respective adult forms and showed no sign of transition between the two. Although it has been known that the male characters are acquired gradually, there have been no accounts of the condition in which one pair of appendages is male and another female.

\section{SIZE.}

The Amphipoda of Connecticut are in general of small size. The largest species of the coast is probably Gammarus locusta a few specimens of which, collected at New Haven, had a length of $30 \mathrm{~mm}$. As in many other groups of animals a larger size is attained in the Arctic regions or in the cold waters of great depths. Thus Sars records a length of $48 \mathrm{~mm}$. for Gammarus locusta in the Arctic regions, and Professor S. I. Smith (Ann. and Mag. Nat. Hist., ser. 5, vol. I4, page 18I, I884) records an Amphipod, Eurysthenes gryllus Boeck, dredged by the "Albatross" in I9I7 fathoms which had a length of $4 \frac{1}{2}$ inches. This probably represents the largest known member of the group. At the other extreme of size are Stenothoe, $2 \mathrm{~mm}$, Dexamine thea, $3 \mathrm{~mm}$., and Corophium cylindricum, 3-4 mm. in length.

\section{COLOR.}

The colors of the Amphipoda are frequently quite brilliant in life, but with scarcely an exception specimens bleach to such an 
extent in preservatives that at best only a few spots of pigment of a chocolate brown or black remain.

The usual color is whitish or grayish but a few of the native species exhibit very characteristic pigmentation. Leptochcirus pinguis, for example, retains its dark chocolate spots even after years in alcohol. Unciola irrorata is mottled with bright crimson. Jassa marmorata is of a reddish ground color, interrupted by large lighter spots.

Many species also exhibit great variations in coloring. Amphithoe longimana may vary from bright green to bluish green, or nearly colorless, and also from light to dark reddish brown.

According to Holmes (Biol. Bull., vol. 2, p. I8I, I902) the color of some individuals is by no means constant. In Amphithoe longimana, the species studied by Holmes, the color is due especially to the pigment cells although the color of the blood and tissues, the contents of the alimentary canal, and the color of the reproductive glands also affect that of the body, as scen by the naked eye. In one specimen the general blue color of the blood and tissues after five days had disappeared, the green becoming more nearly like the typical green of other forms, and by the ninth day the tissues were whitish. This whitening took place in spite of the fact that abundant quantities of green algæ were consumed.

The most important factors in determining the color changes in Amphithoe longimana are the reddish-brown pigment spots which are scattered all over the body and on most of the appendages, especially near the proximal end: These pigment sputs change very slowly, generally requiring several hours to effect a change from the expanded to the contracted condition.

$$
\text { HABITAT. }
$$

The Amphipoda are exclusively aquatic in their habitat, and very generally they are marine. It is only among the Orchestiidx. that there is an approach to a terrestrial habitat. Talorchestıa longicornis occupies a zone of the beach a short distance abore high-water mark but sinks its burrows to a depth at which the sand is always moist. Orchestia palustris and $O$. agilis also live near high-water mark, the latter occupying a lower zone than the 
former. Orchestic palustris prefers mud, and as it is able to survive exposure to brackish or nearly fresh water, it is often found in salt marshes and may find its way to some distance from the shore. Della Valle mentions $O$. gammarcllus, in which species he includes $O$. palustris, as occurring several kilometers from the sea shore at Naples. Allorchestes littoralis also occurs high upon the beach, according to Holmes. ITith these fer: exceptions, howerer, the Amphipodit are thoroughly aquatic.

In New England there are only three species which occur 11 fresh water: (rangony temus, which was found by Smith in wells at Midelletown, Dikcrogammarus fasciatus, and Hyalella knickerbockeri.

Dredging operations have been so incomplete in the waters of Long Island Sound within the bounds of the State that it is imposible to generalize from these data alone. The extensive observations made in the nearby waters of Vineyard Sound a'nd Buzzards Bay by Verrill and Smith and also by Sumner, Osburis, and cole may, it would seen, be extended in the most general way to the shores and waters of Long Island Sound.

The following species are known to occur at the surface and to be taken in towing:

Allorchestes littoralis

Ampelisca macrocephala

Amphithoe longimana

A. rubricata

Batea secunda

Byblis serrata

Calliopius laviusculus

Carinogammarus mucronctus

Corophium cylindricum

Deramine thea

Elasmopus levis

Gammarus anmulatus

G. locusta

Grubia compta

Hyperia galba

Leptocheirus pinguis

Microdeutopus gryllotalpa

Paraphoxus spinosus

Pontogeneia inermis

The following species are found most commonly in eel-grass and mud:

Amphithoe longimana

A. rubricata

Caprella geometrica

Carinogammarus mucronatus

Elasmopus levis
Grubia compta

Leptocheirns pinguis

Lysianopsis alba

Microdeutopus gryllotalpa 
The following species are found on piles among Hydroids, sponges, etc. :

Allorchestes littoralis

Caprellidæ

Corophium cylindricum

Elasmopus levis

Gammarus locusta

Grubia compta
Melita nitida
Microdeutopus gryllotalpa
Stenothoe cypris
S. minuta

On sandy shores the more common species are the following: Allorchestes littoralis

Orchestia agilis

Talorchestia longicornis
T. megalophthalma

Haustorius arenarius

Unciola irrorata

The more common species that are found on rocky shores between high- and low-water marks, and often in the greatest abundance, are the following:

\section{Orchestia agilis \\ O. palustris}

Gammarus locusta

Amphithoe rubricata

\author{
Elasmopus levis \\ Gammarus marinus \\ Unciola irrorata
}

O. agilis is especially abundant beneath masses of decaying sea weed. Gammarus locusta is more common under stones and among rockweed at low-water mark. Amphithoc mbricata abounds in similar situations but apparently prefers Ulia to rock weed. Unciola irrorata is found only at low-water mark.

\section{MOVEMENTS.}

In general the Amphipoda are very agile and energetic except those species which inhabit tubes, usually of their own construction, or lie buried in the sand or in excavations of wood, like Chelura.

The most constant and uniform movement is that of the pleopods, by which a current of water is constantly passed forward over the gills. Besides these movements it has been observed in some species that the mouth parts move more or less regularly as if the animal were eating although there may be no food whatever in the water. In eating, the mouth parts of Orchestia agilis vibrate about $\mathrm{I} 2 \mathrm{O}$ times a minute. 
Although the Amphipoda possess three different kinds of locomotor organs, the pereiopods, pleopods, and uropods, which are used respectively for crawling, swimming, and leaping, it is only in a few species of Orchestiide that we find all three methods of locomotion employed. Lnlike many of the higher crustaceans locomotion is always forward. The most general method is swimming. In order to obtain a start in swimming the animal usually extends the abdomen with some vigor - this part of the body being carried, when the animal is at rest, curled up beneath the body - and then maintains its motion by means of the rapid vibration of the pleopods. In swimming vertically, however, the abdomen frequently aids in the propulsion of the body, as in starting. While swimming, the body is well straightened, the antenne are held out in front of the body and move slightly as if exploring, and the pereiopods are held directed backwards. The animal seems to have some difficulty in maintaining its balance for it frequently rolls over and swims with its back or one side or the other downwards.

In walking or crawling there are two quite distinct methods. In those species whose bodies are depressed like Corophium, for example, the body is easily maintained in an upright position and supported by the pereiopods. Where the body is strongly compressed, however, the upright position is with difficulty held and the last two pairs of pereiopods are bent outwards to brace the body. In these forms it is far more usual for the animal to lie on its side and progress by the alternate flexion and extension of the body with the corresponding movements of the pereiopods. Jumping is resorted to only by Orchestia and Talorchestia, and in these forms only when the animal is startled and must escape quickly. This act is accomplished by the uropods and the abdomen which is extended suddenly. Orchestia agilis can casily spring more than a foot into the air. The jumping is ustally aimless and as a result the animal frequently falls upon an unfavorable spot.

In climbing over alge and other irregularities of the bottom, many species employ their antenne as hooks for pulling the body, but the gnathopods are more generally used for this purpose.

Lurrowing has been studied most carefully by Miss Smallwood in Talurchestia which lends itself to the observation of this 
process by its preference when in a glass receptacle for burrowing along the side of the glass. Talorchestia burrows only in fine, loose sand, and when coarser sand or shell fragments are encountered below the surface the animal ceases to burrow. The second antennæ are bent back sharply at the second joint and the head is pushed into the sand. The grains of sand are passed back from the first gnathopods to the anterior pairs of pereiopods while the body is largely supported by the posterior pairs. The sand thus accumulates behind the body, which is more or less curled. At intervals the body is vigorously straightened and the sand projected some centimeters. As the burrow deepens, the sand is simply pushed behind the body by the pereiopods and the hole is closed.

\section{FOOD.}

The Amphipoda, so far as our knowledge goes, are voracious feeders, consuming all kinds of animal and vegetable matter, whether in the fresh condition or putrid. It is only rarely that they have been known to attack and consume living animals, but freshly killed animals are eagerly fed upon. By roughly estimating the amount of fecal matter discharged by a single Amphithoe supplied with an abundance of food (Ulva), Holmes concluded that in twenty-four hours about one-tenth of the body weight was consumed. The greater part of the food of the Amphipoda, probably because of its usually greater abundance, is vegetable; but molluscs, fish, and annelids as well as dead individuals of their own species are quickly consumed. The cast skin is frequently eaten, for in aquarium jars in the laboratory usually only small fragments of the molted skin are observed.

The Amphipoda are not at all discriminating in their choice of food; bleached fronds of Ulva are consumed as readily as fresh green ones which may be lying beside them, and paintcovered straws from old brooms and paper will be eaten when there may be an an abundance of fresh sea weeds and animal tissues at hand.

In eating, the food mass is held by the gnathopods and anterior pereiopods and chewed directly without first being torn apart by the gnathopods. When algæ like Ulva are eaten, the frond is gnawed from the edge into an irregularly shaped excavation of 
rather smooth contour or from a central point where it is puckered or folded.

\section{ENEMIES.}

The principal enemies of the Amphipoda are undoubtedly fish. As noted in the section on the economic importance of the group, the Amphipoda form a very extensive source of food for many of our most highly valued fishes. Even the shore-inhabiting species, like Orchestia, frequently fall prey to Fundulus which come with the tide into every place where there is enough water to cover them and search for every possible material for food. The Amphipoda are usually in concealment when the tide is high but when one leaves its retreat it forms a tempting morsel for a fish. Besides fishes, the shore-inhabiting species must also be destroyed by birds. Although this has never actually been observed, forms of life far more active than the Amphipoda have frepuently been seen to be pursued by birds in the same spots occupied by Orchestia and similar species. Miss Smallwood also describes an encounter which she observed between a half grown Orchestia palustris and one of the staphalinid bectles, in which the latter was victorious. The spiders, which occur in the same localities and occupy the same retreats as individuals of this species, must also serve to keep down the numbers.

\section{RESISTANCE TO ADVERSE CONDITIONS.}

The generally wide distribution of the Amphipoda may be partly accounted for by their power of resisting unfavorable environmental conditions. Many marine, as well as fresh-water, forms are able to survive under conditions which are fatal to almost all other groups. In examining material collected along the shore, it is frequently noticed that after molluses, actinians, and worms decay, the Amphipoda still survive.

Talorchestia, though not living in water normally, is dependent nevertheless upon it, for when placed in perfectly dry sand, specimcns died in less than seven hours, while those placed in partially moistened sand in the laboratory survived ten or twelve days; when the sand is kept completely covered with water, it has been found that this species dies quite soon. Orchestia palustris may remain submerged for days without fatal results 
and yet the species normally abounds in fairly dry surroundings where individuals run about in the dry grass for several hours at a time. Specimens of Orchestia agilis I have found surviving after several hours on a dry laboratory floor in the summer.

The shore-inhabiting forms must necessarily be able to endure considerable changes in the density of the water. Orchestia palustris will bear an exposure for several hours to fresh or brackish water. Talorchestia, according to Miss Smallwood, will bear cxposure to spring water for six and a half hours without fatal results.

\section{MOLTING.}

The frequency with which the Amphipoda molt is not known with any degree of certainty. Holmes found that in Amphithoe of the usual size two successive molts took place in seven or eight days. The frequency decreases as the adult size is gradually attained.

In the process of molting the shin splits transversely along the line joining the head and thorax and on either side of the thorax between the upper margins of the coxal plates and the lower margins of the thoracic rings. The head and antennæ are pulled backwards and the posterior part of the body is pulled forwards, the old skin romaining intact except along the splits just mentioned.

The process may be completed in a quarter of an hour or so, or it may be prolonged over several days. Holnes notes one such case in which the animal died before the molt was completed. Immediately after molting, the animal is rather quiet but in a short time, a quarter of an hour, after the old skin has been shed, it assumes its ordinary activity. The antennæ may become broken during this process but no other appendages have been observed to be lost at this time.

\section{NESTS AND NEST-BUILDING.}

Those species of Amphipoda which possess glandular pereiopods habitually occupy tubes which serve as hiding places for them and from which it is rather difficult to drive them. Usually these tubes are cemented to some solid object, but Cerapus tubularis carries its tube about with it. These tubes are composed of a felt-like mass of fine threads which are secreted by 
the glands of the pereiopods and spun as it were into the characteristic fabric. As the secretion emerges from the opening at the tips of the pereiopods it hardens immediately as in the spicier's web. Bits of alga and grains of sand are frequently woven into the tube which is thus rendered more inconspicuous. Snith has observed that in Microdeutopus bits of fecal matter are also worked into the web, but Ilolmes finds that Amphithoe does not use excrement to increase the tube but passes it out of the nest; accumulations of it usually being seen at both ends of the tube.

The tubes are usually open at both ends and of uniform diameter throughout. Their length is as a rule considerably greater than that of the animal.

In constructing a tube, the first two pairs of pereiopods are seen to be in rather rapid motion, passing back and forth ovet the space which the tube is to occupy. By rolling over and continuing this motion the tubular form is attained.

Amphithoc and various other species frequently leave their nests; they seem, however, to show no particular preference to return to those of their own making, but slip into any one that is unoccupied or proceed to build another, which is done in a remarkably short time, often in less than half an hour. Unciola usually inhabits a tube, but has no spinning glands in its pereiupods and has never been observed to weave a web for itself.

The tube-dwelling forms habitually remain in their tubes with only the head and antenne thrust out. When disturbed Amplithoe retreats further into its tube and seeks safety in flight only when the intruding object is so persistent as to prevent further retreat into the depths of the tube. Holmes has observed Amphithoe dart out for food without letting go of its tube and quickly retract itself with the food in its gnathopods and devour it at leisure within its tube.

The instinct to build tubes develops very early in life. A few days after leaving the brood-pouch, the young set about constructing nests like the adults, and exhibit precisely the same reactions to stimuli and habits.

BREEDING HABITS.

The eggs are discharged from the openings of the oviducts, those from each orifice, according to Della Valle, becoming 
enveloped in a gelatinous capsule, so that when removed from the marsupium each egg mass retains its form. The young remain in the marsupium for some time after their escape from the egg and in some species it has been noted that the young return to the brood-pouch when forcibly removed from it. Observations are scarce regarding the length of time that the brood-pouch is occupied by the eggs and young, but in Orchestia palustris it may not be more than two weeks. Some specimens of Gammarus locusta kept in the laboratory were found to retain the eggs and young from two to two and a half weeks.

From observations made on Amphipoda collected at Woods Hole as well as at Noank and New Haven, females were found carrying eggs on the following dates:

Hyperia, Apr. 4 to June 3 .

Orchomenella pinguis, Jan. 23.

Ampelisca spinipes, July I3 to Aug. I5.

Byblis serrata, July 23.

Stenothoe mimita, Aug. and Sept.

Lafystius sturionis, Oct. 20 and Nov. 24.

Calliopius lcvinsculus, Jan. II, 22; April I, 20, 27; May 6, 2I; July 3I ; Aug. I, 6, 29; Dec. II, 25.

Sympleustes glaber, April and July I3.

Batea secunda, Aug. 23.

Pontogeneia inermis, July I3.

Melita nitida, Aug. I7.

Elasmopus levis, Aug. I5, I7.

Gammarus locusta, May 3; July 3I ; Aug. 6-I9.

G. anmulatus, Mar. 6; Apr. I, 20, 27; May; June 21.

Carinogammarus mucronatus, Aug. I4, I7.

Orchestia agilis, May; June; first two weeks of July; Aug. I3 very few eggs.

Orchestia palustris, July 9, $2 \mathrm{I}$.

Talorchestia longicornis, June I4 (according to Bumpus, eggs in a late stage of development) to Aug. I3. (Miss Smallwood found the young free in the sand at Cold Spring Harbor and very few females bearing young by the end of July.)

Allorchestes littoralis, Aug. I8.

Microdeutopus gryllotalpa, July I3 to Aug. I8. 
Leptocheirus pinguis, Aug. Io to I8.

Amphithoe rubricata, Aug. 6 to 17.

A. longimana, Aug. I3 to 17 .

Grubia compta, July and August.

Jassa marmorata, July 3 I to Aug. I9.

Ischyrocerus anguipes, April and July 17.

Cerapus tubularis, July 4, $2 \mathrm{I}$.

Ericthonius rubricomis, Aug. IO.

Unciola irrorata, May I ; July I3; Aug. 9, I8.

Corophium cylindricum. Jan. 5: July it to 2 I; Aug. 9 to 29.

Caprellidx, March, July, August, and September.

The number of eggs deposited at one time varies greatly in different species. Observations have been made on a very few species so that our knowledge is limited. Orchestia agilis carries from seven to fifteen eggs, while one specimen of Calliopins liciusculus, whose nöstegites are unusually large (Fig. 17), was found with nearly seventy eggs.

Copulation seems to be in most cases an act quite independent of the sexual condition of the individuals, although females bearing eggs in the marsupium are practically never found with a male. Holmes has studied the copulating of several species and finds that the recognition of the female by the male is purely the result of chance which brings the two sexes into collision with each other. That copulation tales place is due to the difference in the reaction of the two sexes when in collision. When two males collide both become active and for a few moments strive to grasp each other but because of the mutual activity fail to accomplish their end; when two females chance to meet, both roll up and become quiescent and in a few moments swim about as before. When, however, opposite sexes meet, both pursue the tactics described above with the result that the male grasps the female and swims off with her lying perfectly passive, her body strongly flexed. In all the species observed the female remains inactive save for the movement of the pleopods to maintain a respiratory current.

In copulation the male ordinarily retains his hold of the female by hooking the dactyls of his pereiopods beneath the edges of the coxal plates of the female; the gnathopods are used 
apparently only when a sudden disturbance renders the hold of the male insecure. The male carries the female thus for several days or probably much longer, and can with difficulty be separated without injuring him.

Deposition of the eggs and fertilization have been observed rarely. Della Valle has described the process fully in Gammarus pungens, a fresh-water species of Europe. Deposition of the eggs takes place soon after molting and while the eggs are being discharged the male slips around the female so that their two heads are still pointing in the same direction but their ventral sides are directed toward each other and the openings of the vasa deferentia lie close to those of the oviducts. In this position the spermatic fluid is discharged over the eggs and fertilizes them. Immediately following the ejaculation the male returns to his former position with reference to the female.

\section{LIST OF SPECIES.}

In the following list an * indicates that a species is likely to be met with in the State although up to this time it has been unreported. A $\dagger$ indicates that a species is found in fresh water. Heavy-faced type indicates a species unreported hitherto from New England.
HYPERIIDEA
Hyperia galba (Mont.)
A. spinipes Boeck
Byblis serrata Smith
GAMMARIDEA。
HAUSTORIIDE
LYSIANASSID E
Hanstorius arenarius (Slabber)
Lysianopsis alba Holmes
PHOXOCEPHALIDE
Orchomenclla pinguis (Boeck) Phoroccphalus holbölli (Kr.)
*Tmetony.r cicada (Fabr.)
T. quadratus sp. nov. * Hipponedon serratus Holmes *Anonyx migax (Phipps)
STEGOCEPHALIDE
* Stegocephalus inflatus Kr.
AMPELISCID
Ampelisca macrocephala Lillj.
Paraphorus spinosus Holmes
*Harpinia plumosa (Kr.)
METOPIDE
* Metopa groulandica Hansen
STENOTHOID.E
Stenothoe cypris Holmes
S. minuta Holmes
* A. compressa Holmes
LAFYSTIID王
*A. agassizi (Judd)
*Lafystius sturionis $\mathrm{Kr}$. 
CEDICERID

$\nmid$ Hyalclla knickerbockeri (Bate) *Monoculodes edriardsi Holmes Allorchestes littoralis Stim.

CALLIOPIIDE

Calliopins laviusculus (Kr.) * Apherusa gracilis Holmes

PLEUSTIDE

Sympleustes glaber (Boeck)

PARAMPHITHOID E

* Epimeria loricata Sars

BATEIDA

Batea secunda Holmes

PONTOGENEIID压

Pontogeneia inermis (Kr.)

GAMMARID

* Eucrangony.r gracilis (Smith) Grubia compta (Smith)

†Crangony. $x$ tenuis Smith

* Melita parvimana Holmes

$M$. dentata (Kr.)

$M$. nitida Smith

Elasmopus levis (Smith)

Gammarus locusta (Linn.)

G. anmulatus Smith

G. marinus Leach

Carinogammarus mucronatus (Say)

+ Dikerogammarus fasciatus

(Say)

$$
\text { JASSID } \mathbb{E}
$$

Jassa marmorata Holmes Ischyrocerus anguipes $\mathrm{Kr}$.

COROPHIID.E

Cerapus tubularis Say * Ericthonius rubricomis (Stim.)

E. brasiliensis (Dana)

Unciola irrorata Say

Siphonecetes smithianus

Rathbun

Corophium cylindricum (Say)

DEXAMINIDE

Dexamine thea Boeck

ORCHESTIID A

Orchestia agilis Smith

CHELURID $A$

* Chelura terebrans Phil.

O. palustris Smith

CAPRELLIDEA Aeginella longicomis ( $\mathrm{Kr}$. )

Talorchestia longicornis (Say) Caprella geometrica Say

$T$. megalophthalma (Bate) ${ }^{*} C$. aquilibra Say

Hyale prevostii (Milne-Ed.) C. linearis (Linn.)

HYPERIIDEA.

Head not fused with first thoracic segment; maxillipeds without palp; coxal plates small or wanting; head generally large 
and tumid, with large, compound eyes which cover nearly the whole side of the head; gills on three or four thoracic segments; last two abdominal segments fused, uropods usually with laminate rami, forming a tail fan. Hepato-pancreatic tubes two or none, rectal gland wanting; heart with two pairs of ostia, rarely three.

Exclusively pelagic in habitat.

\section{Hyperia Latreille.}

Antennæ in female very small, subequal.

Mandibles with molar tubercle large, palp of moderate size with the second and third joints subequal in length. First maxillæ with palp not greatly expanded, inner corner produced to a tooth-like projection. Maxillipeds with outer plates obtuscly pointed, inner margin with small tufts of setæ.

Gnathopods scarcely chelate; carpus produced ventrally, especially in second pair. Pereiopods comparatively short, robust, and subequal in length. Uropods broad, with foliaceous rami. Telson large.

\section{Hyperia galba (Montagu).}

I8ı3. Cancer Gammarus galba, Montagu, Trans. Linn. Soc. London, vol. II, p. 4, pl. 2, fig. 2.

I89o. Hyperia galba, G. O. Sars. Crust. Norway, vol. I, p. 7 , pls. 2 and 3 , fig. I.

Head much deeper than long, with reniform eyes covering whole lateral aspect; back strongly arched.

Antenna in female very short, subequal. Mandibles with long, slender three-jointed palp.

Gnathopods small, scarcely chelate, and with only a few bristles; first pair with carpus having postero-distal angle expanded somewhat to form an acutely triangular lobe which is provided with a few setæ; propodus oblong, slender, with posterior margin finely serrate; dactyl small. Second pair with carpus greatly produced at posterior apex, forming a slender triangular lobe which reaches beyond the middle of the propodus; the latter quite similar to that of the first gnathopod.

Pereiopods subequal in length, robust, and almost devoid of setæ; coxal plates small; basal joint of each stout.

Last two abdominal segments fused; uropods broad, with foliaceous rami; second pair not extending as far as the first; ter- 


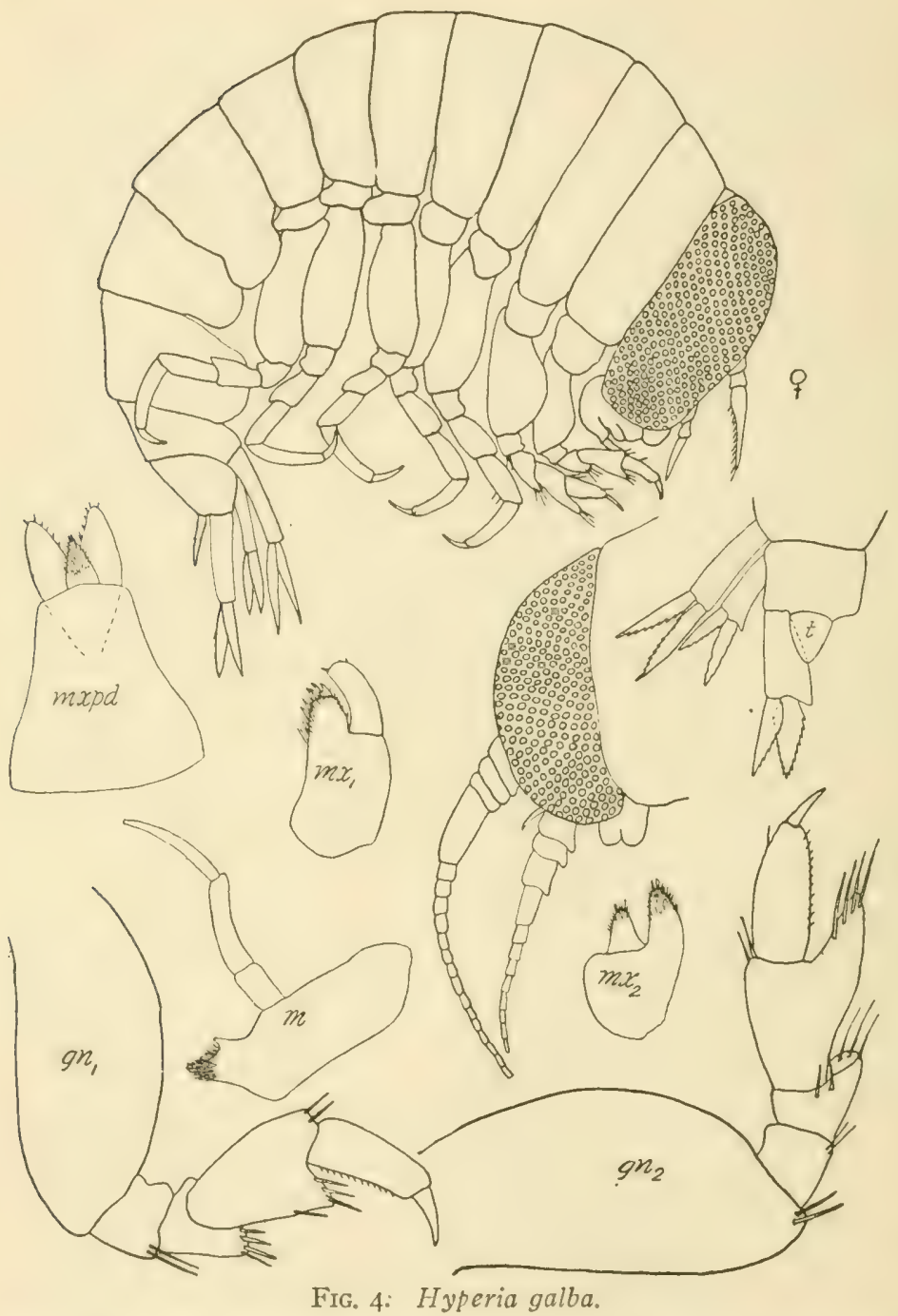

minal pair with peduncle broader distally than proximally, with rather broad, sharply pointed, subequal rami.

Telson slightly longer than broad, triangular.

In the male the antenne exceed half the length of the body.

Length $15 \mathrm{~mm}$. According to Bovallius, Arctic specimens may attain a length of $20 \mathrm{~mm}$. 
The species is abundant and widely distributed. It has been reported from the Arctic Ocean, Norway, Great Britain, France, Greenland, Nova Scotia, Grand Manan; Eastport, Maine; Salem, Woods Hole, Massachusetts; off Fishers Island, New Haven, Noank, Connecticut.

It is found commonly in the jelly fish, Aurclia. Sars states that several individuals, males, females, and young, may occur in each medusa.

Miss Rathbun in her List of the Crustacea of New England notes that Hypria medusarum has been found off New Haven and at Noank. In the material at my disposal I was unable to identify $H$. medusarum, and am inclined to believe that $H$. galioa is the only Hyperid occurring in the waters of the State.

\section{GAMMARIDEA.}

Head not fused with first segment of thorax, and not tumid; maxillipeds with palp of 2 to 4 joints; coxal plates always well developed; eyes simple or compound, of various sizes, but never covering whole side of head; gills present on 5 or 6 segments; first uropod always biramus. Hepato-pancreatic tubes generally 4 , occasionally 2 ; rectal glands 2 or I, sometimes rudimentary; heart with 3 pairs of ostia, rarely one pair.

Typical Amphipoda.

\section{KEY TO THE GENERA OF GAMMARIDEA.}

A. Mandible not denticulated, palp 3-jointed; antenna I with stout peduncle and accessory flagellum well developed; coxal plates deep; gnathopod 2 elongated and slender, ischium elongated, propodus small and densely setose, dactyl rudimentary (Lysianassidæ).

B. Teison entire

Lysianopsis p. 5 I

BB. Telson cleft.

C. Postero-lateral angle of third abdominal segment not greatly produced.

D. Mandibular palp inserted directly above molar tubercle

Tmetonyx p. 54

DD. Mandibular palp inserted behind molar tubercle .....

CC. Postero-lateral angle of third abdominal segment

Orchomenella p. 58

produced, with a deep sinus above.

D. Peduncular joints of antenna I produced distally

Hippomedon. 
DD. Peduncular joints of antenna I not produced distally

Anonyx.

AA. Without this combination of characters.

B. Eyes simple, usually 4 (Ampeliscidæ).

C. Uropod 3 extending much beyond the others, telson ob-

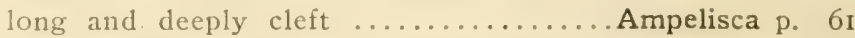

CC. Uropod 3 not extending much beyond the others, telson short and not deeply cleft ..................... 67

$B B$. Eyes usually present, never more than one pair and never simple.

C. Pereiopods without dactyls .................... 70

CC. Perenopods with dactyls.

D. Rostrum produced into a hood over the antennx; pereiopod 4 much longer than last pair (Phoxocephalidæ).

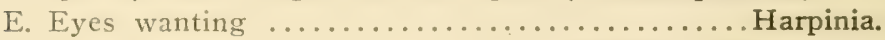
EE. Eyes small ................. Phoxocephalus p. 73 EEE. Eyes large ......................... 75

DD. Rostrum not as above.

E. Coxal plate 4 greatly enlarged to form large lateral shield.

F. Uropod 3 biramous ..............Stegocephalus p. 60 FF. Uropod 3 uniramous.

G. Mandibular palp small, 3-jointed ............... GG. Mandibular palp wanting ......... Stenothoe p. 78 EE. Coxal plate 4 not greatly enlarged.

F. Body depressed, rostrum large, broad not acute; no accessory flagellum; mandibular palp large; gnathopod I simple; gnathopod 2 weakly sub-

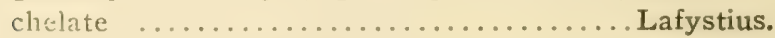

FF. Without this combination of characters.

G. Last perciopod the longest, dactyl styliform; eyes nearly contiguous above ...... Monoculodes p. $8_{3}$ GG. Dactyl of last pereiopod not styliform.

H. Gnathopod I rudimentary ........... Batea p. 89 HH. Gnathopod I not rudimentary.

I. Pereiopods I and 2 without spinning glands, J. Antenna I with calceoli.

$\mathrm{K}$. Last joint of peduncle of antenna I produced to form a triangular process..

Calliopius p. 86

KK. Last joint of peduncle of antenna $\mathrm{I}$ not so produced ..........Pontogeneia p. 9I

JJ. Antenna I without calceoli.

K. Mandible with palp; uropods 2 and 3 not enormously developed.

L. Thoracic segments strongly tuberculated Epimeria. 
LL. Thoracic segments not strongly tuberculated.

M. Postero-lateral margin of third abdominal segment serrated ........

Apherusa.

MM. Postero-lateral margin produced to a single tooth, above which is a small sinus.

N. Uropod 3 biramous Sympleustes p. 84 NN. Uropod 3 uniramous .. Unciola p. 165

MMM. Postero-lateral margin otherwise; accessory flagellum present; uropod 3 flattened and usually projecting beyond the others; gnathopods subchelate, gnathopod 2 larger than $I$ and larger in male than female; telson small and flattened (Gammaridæ).

N. Uropod 3 uniramous Crangonyx p. 95 NN. Uropod 3 biramous.

O. Telson slightly emarginate.....

Eucrangonyx p. 93

OO. Telson deeply cleft.

P. Inner ramus of uropod 3 rudimentary, scale-like Melita p. 98 PP. Inner ramus of uropod 3 often smaller than outer, but not rudimentary.

Q. Last 3 abdominal segments with fascicles of spines.

R. Body with median carina..

Carinogammarus $\mathrm{p}$. II 3

RR. Abdominal segments 4 and 5 raised dorsally to spiniferous tubercles ...

Dikerogammarus p. I05

RRR. Body without carina or tubercles Gammarus p. I07

QQ. Last 3 abdominal segments without fascicles of spines; uropod 3 with comparatively broad, short rami ..

Elasmopus p. 102

KK. Mandible with palp; uropods 2 and 3 enormously developed .... Chelura p. I74

KKK. Mandible without palp; no accessory flagellum; uropods 2 and 3 normal. 
L. Uropod 3 biramous; antenna I long ....

Dexamine p. 115

LL. Uropod 3 uniramous; antenna I much shorter than antenna 2 (Orchestiidæ).

M. Maxilliped with 3-jointed palp; antenna I shorter than peduncle of antenna 2.

N. Gnathopod I of female subchelate

Orchestia p. II 8

NN. Gnathopod I of female simple ..

Talorchestia p. 122

MM. Maxilliped with 4 -jointed palp; antenna I longer than peduncle of antenna 2.

N. Gnathopod 2 in male with carpus masked by merus ..... Hyale p. 126

NN. Gnathopod 2 in male with carpus produced between merus and propodus.

O. Telson undivided ....Hyalella p. I28

OO. Telson cleft ....Allorchestes p. I3I

II. Pereiopods I and 2 glandular; coxal plate 4 not excavate behind.

J. Gnathopod I much larger than gnathopod 2 (Aoridæ).

K. Gnathopod I in male with carpus prolonged to form a strong thumb-like process ............ Microdeutopus p. I33

KK. Gnathopod I in male with carpus not so produced ..................embos p. I36

JJ. Gnathopod I never much larger than gnathopod 2, usually smaller.

K. Uropod 3 biramous.

L. Rami of uropod 3 not uncinate

(Photidx).

M. Rami of uropod 3 very unequal in size ................. Photis p. I39

MM. Rami of uropods 3 not very unequal in size.

N. Antenna I with third joint of peduncle shorter than first .......

Leptocheirus p. I43

NN. Antenna I with third joint of peduncle longer than first ........

Podoceropsis p. I4I

LL. Rami of uropod 3 very short, outer one uncinate. 
M. Lower lip with principal lobes notched (Amphithoidæ).

N. Without accessory flagellum; uropod I with peduncle not produced below rami .......Amphithoe p. 147

NN. Accessory flagellum present; uropod I with peduncle produced to spiniform process below rami

Grubia p. I5I

MM. Lower lip with principal lobes entire in front (Jassidæ).

N. Gnathopod 2 in male with propodus having a thumb-like process; in female much larger than gnathopod I .............. Jassa p. I54

NN. Gnathopod 2 in male without thumb-like process; in female not much larger than gnathopod I

Ischyrocerus p. I56

KK. Uropod 3 uniramous (Corophiidæ).

L. Uropod 2 uniramous ........ Cerapus p. I59

LL. Uropod 2 biramous.

M. Gnathopod 2 in male complexly subchelate ............Ericthonius p. I6I

MM. Gnathopod 2 in male simply subchelate.

N. Mandibular palp uniarticulate ....

Siphoncecetes p. I68

NN. Mandibular palp biarticulate ....

Corophium p. I7o

LYSIANASSIDÆ.

Eyes usually large, compound.

First antennæe not longer than second pair; first joint of peduncle tumid; accessory flagellum always present.

Mandibles with cutting edge not denticulate; molar tubercle seldom very robust; palp triarticulate.

Second gnathopods slender, with ischium elongate, carpus and propodus spinulose, and dactyl minute.

Terminal uropods biramous.

\section{Lysianopsis Holmes.}

Antennæ short and differing little in the two sexes.

Mandibles edentate, furnished with 3 -jointed palp and a small molar process nearer the cutting edge than is the base of the 
palp; first maxille with narrow inner plate furnished with two apical sctæ, palp 2-jointed; maxillipeds with inner plate narrow and extending beyond middle of outer one, outer plate oval, inner margin devoid of spines; palp narrow.

First gnathopods stout, simple; second gnathopods slender, ischium elongated, propodus short and setose, with dactyl very small, near middle of distal margin of propodus.

Postero-lateral angle of third abdominal segment rounded. Uropods biramous. Telson entire.

\section{Lysianopsis alba Holmes.}

Ig03. Ly'sianopsis alba, Holmes, Amer. Naturalist, vol. 37, p. 276 .

1905. Lysianopsis alba, Holmes, Bull. Bur. Fish., vol. 24, p. 475 , pl. 5 , fig. I.

Interantennal lobes prominent and rounded; eyes large, oval.

First antennæ short with basal joint of peduncle stout, and longer than the next two; principal flagellum a little longer than peduncle; accessory flagellum one-half the length of the principal one. Second antennæ about as long as first, with flagellum as long as peduncle.

First gnathopods simple, stout, basal joint broad; carpus somewhat inflated; propodus tapering distally, dactyl moderately stout. Second gnathopods very long and slender; merus densely setose on convex posterior margin; carpus long, with both front and hind margins convex, densely setose anteriorly; propodus subcordate, small, densely setose; dactyl very small.

Posterior group of pereiopods increasing in length rapidly posteriorly, the last pair quite long and slender and having posterior margin of basal segment serrated; two preceding pairs with basal segments similarly serrated.

Fourth abdominal segment slightly indented dorsally.

First uropods extending further back than second, which extend further back than the third; rami of first pair nearly as long as peduncle, styliform; peduncle of last uropods very stout, longer than the rami and produced into a triangular projection at distal end of upper margin.

Telson oblong, entire, rounded distally. 
Iolmes found the species in the mud at IVoods Hole, Massachusetts, and off Nobska at the same place. In the Biological Survey of Wroods Ilole this species was dredged in 4 to 13 fathoms on bottoms of sand and gravel. It has also been collected within Connecticut at Noank in mud and grass; off Stonington; Long Island Sound.

According to Ilolmes, the species has the habit of lying very quiet for a long time with its body strongly flexed and of starting quickly when disturbed and swimming vigorously for a time and then coming to a sudden stop with its body flexed as before.

\section{Tmetonyx Stebbing.}

Epistome more or less projecting and rounded in front.

Antennæ with small calceoli in male.

Mandibles with large molar tubercle, obliquely truncate, with palp attached dorsal to it, second and third joints of palp subequal. First maxillae with two setae on inner plate; outer plate broad and obliquely truncate; palp with several spine teeth apically. Second maxilla with imner plate smaller than outer. Maxillipeds with outer plates large, oblong oval, reaching as far as second joint of palp which is not very robust.

First gnathopods slender with propodus oblong and palm very oblique and rather indistinctly defined. Second gnathopods with ischitum greatly elongated; propodus not at all produced beneath the minute dactyl. First pereiopods elongate, with large basal joint.

Third uropods projecting beyond the second; rami minutely denticulate. Telson oblong, deeply cleft.

The name Hoplony.t by which this genus was formerly know11, was preoccupied as a coleopteran gentus.

\section{Tmetonyx cicada (Fabricius).}

1891. Hoplonyx cicada, G. O. Sars, Crust. Norway, vol. I, p. 92, pl. 32, fig. 2 .

Iy05. Tmetony'x cicada, Stebbing, Das Tierreich, Lief, 2r, p. 74 .

Ilead with interantennal lobes only slightly projecting and rounded.

Eyes not very large, narrow above, broader below. 
First antennæ as long as head and first two thoracic segments together, with thick peduncle, the first joint of which is more than twice as long as the other two combined; flagellum not quite twice as long as peduncle; accessory flagellum not quite half as long as flagellum, made up of seven joints. Second antennæe half again as long as first pair; flagellum made.up of about 28 segments. First gnathopods with propodus as long as carpus with palm somewhat arcuate and finely serrated but not defined below by prehensile angle. Second gnathopods with propodus half as long as carpus. Two posterior pairs of pereiopods rather elongated, with basal joint of moderate size.

Anterior coxal plates more than twice as deep as respective segments and increasing in height posteriorly; fourth pair produced below the posterior emargination to a narrow lobe, obtuse at the tip; fifth pair nearly as deep as broad.

Third abdominal segment with postero-lateral angles drawn out to very short point.

Last pair of uropods with inner ramus scarcely longer than basal joint of outer. Telson nearly twice as long as broad, slightly tapering distally and with two pairs of dorsal denticles, and very narrow cleft extending almost to the base.

\section{Length I $5 \mathrm{~mm}$.}

Distribution; Arctic regions; Norway; British Isles; Iceland; Greenland; Labrador; IVoods Hole, Martha's Vineyard, Massnchusetts.

The species ranges in depth to over 600 fathoms.

\section{Tmetonyx quadratus sp. nov.}

Head produced to a small rostrum; interantennal lobes rounded. Body stout.

Eyes oval; deeply pigmented in alcoholic specimens.

First antennæ scarcely as long as head and first two thoracic segments together, with short peduncle about two-thirds as long as flagellum; first joint of peduncle large, more than half as broad as long; second and third joints short; accessory flagellum half as long as principal one and made up of six joints. Second antennæe over a third as long as body; last two joints of peduncle subequal in length; flagellum with calceoli and made up of about twenty segments. 
First four coxal plates more than twice as deep as corresponding segments; first pair with front margin considerably shorter than hind one; first and second coxal plates with a minute triangular prolongation at the postero-ventral angle; fourth plate deeply excavated behind to accommodate the fifth which is deeper than wide and bilobed.

First gnathopods of male with merus with hind margin prolonged distally and having several long spines and fine cilia; carpus triangular, as long as propodus and broader, with a dense patch of short cilia on the short hind margin; propodis subrectangular, with oblique palm which is slightly uneven and fincly serrated, prehensile angle prominent and armed with two stout spines. Second gnathopods with short merus having a patch of dense cilia on the convex hind margin; carpus greatly elongated, broadening somewhat distally, with a patch of short cilia situated near proximal end of hind margin and one near distal end of front margin, which also bears several long setæ; propodus only slightly longer than wide, densely setose and produced slightly to form a very weak chela with rudimentary dactyl.

Third, fourth, and fifth pereiopods with basal joints expanded and serrated on posterior margins.

Third abdominal segment with postero-lateral angle not produced, but forming nearly a right angle.

First and second uropods with styliform rami; the first pair extending beyond the second pair; third pair extending slightly beyond the first; rami foliaceous, inner one extending scarcely farther than basal joint of outer, inner margins of rami with setie, outer margins with short strong spines.

Telson flat, twice as long as wide, cleft nearly to the base, each apex provided with a small spine.

Length I3 $\mathrm{mm}$.

The species is represented by four specimens collected by Professor Verrill off Stonington, Comnecticut, in April, 1873 , in sand at a depth of " $4-6 \mathrm{f}$."

It is distinguished from $T$. cicada by the shape of the eyes which in the latter species are narrow above and dilated below; by the presence of a definite prehensile angle on the propodus of the first gnathopod; by the form of the postero-lateral angle of 
No. 26.]

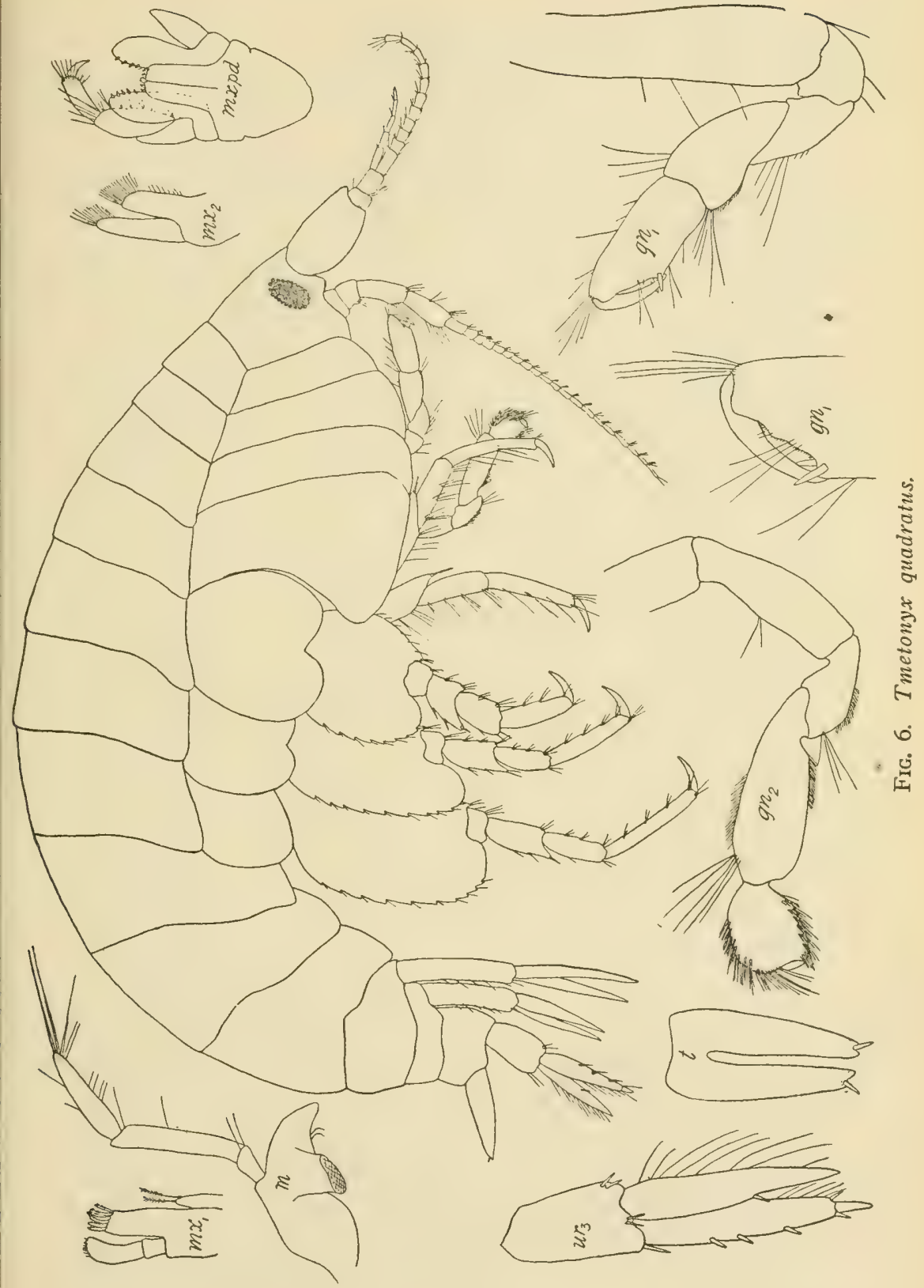


the third abdominal segment; and by the greater length of the last peduncular joint of the first antenna.

\section{Orchomenella G. O. Sars.}

\section{Coxal plates large.}

First antennæe with moderately developed accessory flagellum; second antenne in females slightly longer than first, not greatly elongated in male.

Matidibles with slender palp, attached behind the small molar tubercle; first maxillie with outer plate very obliquely truncated at tip; maxillipeds normal.

First gnathopods strong, subcheliform; second gnathopods with short propodus which is dilated distally and densely setose, apex slightly produced beneath the minute dactyl.

Pereiopods short, basal joint of last three pairs laminar.

Terminal uropods in female scarcely reaching beyond the preceding pair, rami partly denticulated at the edges; in male only the outer ramus provided with setæ.

Telson reaching beyond peduncle of terminal uropods, oblong, triangular, deeply incised, lobes not widely separated.

\section{Orchomenella pinguis (Boeck).}

I890. Orchomenella pinguis, G. O. Sars, Crust. Norway, vol. I, p. 67 , pl. 24 , fig. 2.

Inn5. Tryphosa pinguis, I Iolmes, Bull. U. S. Bur. Fish., vol. 24, P. 473 .

Fyes rather large, elongated, not pigmented in alcoholic specimens. Interantennal lobes of head produced and narrowly rounded.

First antenna short, with stout peduncle having second and third joints very short; first joint of principal flagellum elongated and denscly setose, succeeding joints short; accessory flagellum moderately developed, four-jointed, extending beyond the third joint of principal flagellum. Second antenna much longer than first, especially in the male in which it scarcely equals mne-half the body length; peduncle short; flagellum in male very slender.

First gnathopods with deep coxal plate slightly narrower ventrally; basal joint slender; carpus with narrow posterior lobe; propodus rectangular with palm nearly transverse and slightly 


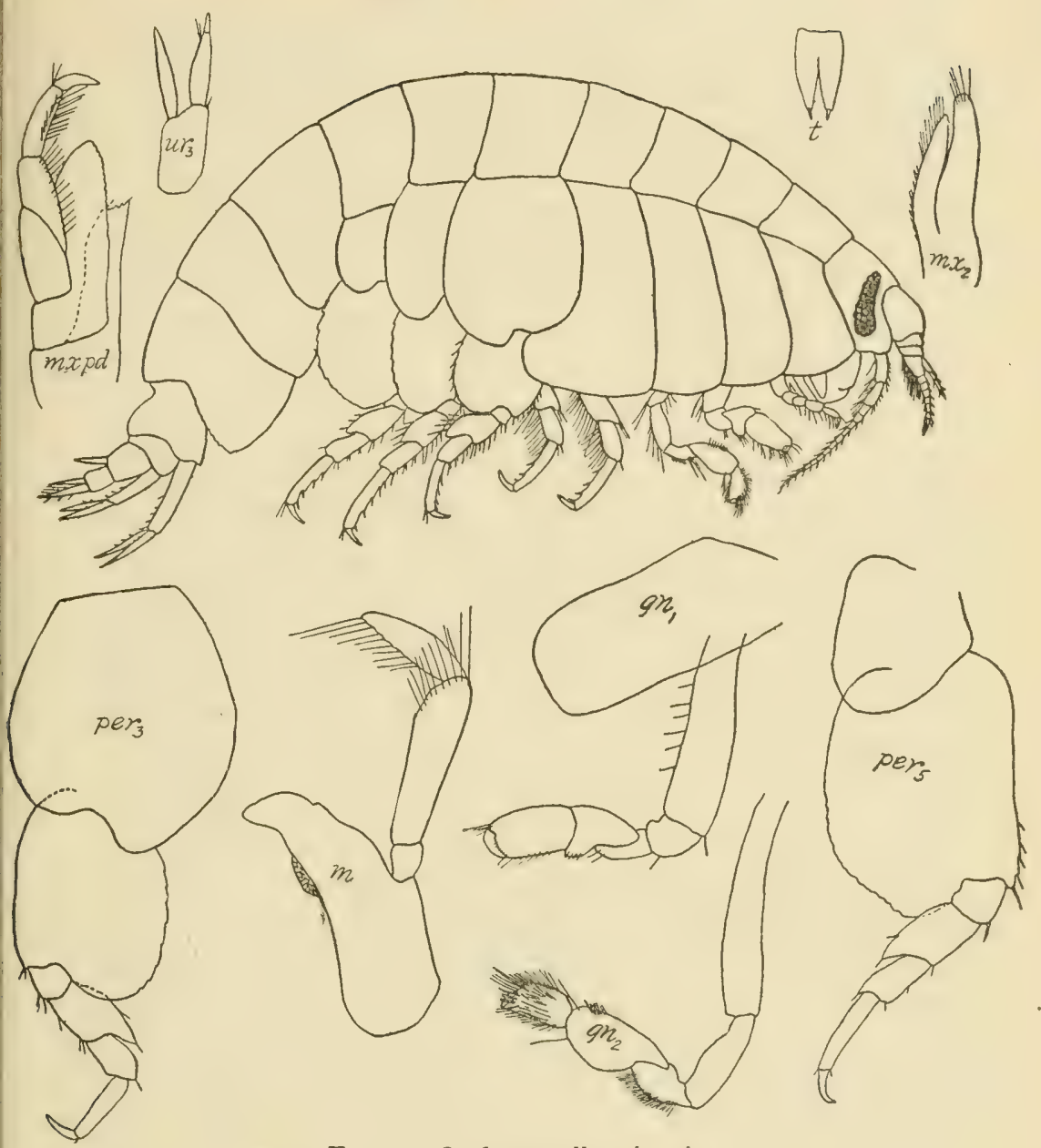

FIG. 7. Orchomenella pinguis.

convex. Second gnathopods with propodus oblong, densely setose, postero-distal angle produced; dactyl, very small; carpus considerably larger than propodus with posterior margin strongly convex.

Posterior pereiopods short with basal joints broadly suboval and shorter than rest of limb. Coxal plates large, those of first four appendages being more than twice as deep as their corresponding segments; the fifth is much deeper than wide, with 
posterior part of lower margin produced into a rounded lobe. First three ahdominal segments with postero-lateral angles evenly rounded and with margin above angle minutely crenulated ; futrth aldominal segment with a rather deep dorsal depression near the anterior end.

Terminal uropods with styliform rami; inner ramus more slender than outer and extending only as far as basal segment of the latter. Telson tapering distally and cleft to beyond the micldle.

Color whitish.

\section{Length, $5 \mathrm{~mm}$.}

Distribution: Arctic regions; Norway; Greenland; Labrador; Woods Hole; off Martha's Vineyard; Long Island Sound.

This species has been referred recently to the genus Tryphosa but it differs from the latter particularly in the position of the mandibular palp which is behind the molar tubercle; in the carpus of the first gnathopod which is shorter than the propodus (in Tryphosa the two joints are more nearly of the same length) and in the propodus of the second gnathopod which is not produced beneath the dactyl in Tryphosa.

\section{STEGOCEPHALIDA.}

\section{Head short. Fourth coxal plates large.}

First antenne with accessory flagellum uni- or biarticulate. Second antennx seldom much longer than first.

Lower lip without inner lobes. Mandibles without molar tubercle or pailp. First maxille with inner plate with numerous setæ. Second maxillæ with inner plate very broad and setose, outer narrow.

Gnathopods not subchelate. Third pereiopods with basal joint not expanded.

Terminal uropods biramous. Telson small.

\section{Stegocephalus inflatus Kröyer.}

ISor. Stcgocephalus inflatus, G. O. Sars, Crust. Norway, vol. I, p. I98, pl. 69.

Body tumid and smooth. Rostrum prominent, deflexed, and with a deep sinus below.

Eyes wanting. First antennx with accessory flagellum having second joint minute.

Mandibles with palp wanting. 
First five coxal plates greatly developed and presenting an evenly rounded contour below. First gnathopods stouter than second; propodus of both narrow. Last pereiopods with inferoposterior angle of basal joint produced and acute.

Terminal uropods with lanceolate rami which are nearly twice as long as peduncle. Telson cleft beyond middle, strongly tapering in distal half.

This species is extensively distributed in the Arctic and north Atlantic Oceans; Grand Manan; Eastport, Maine; South of Block Island; near Woods Hole, Massachusetts.

\section{AMPELISCIDAE.}

Head truncate in front, no rostrum.

Eyes simple, usually two pairs.

First antennæ without accessory flagellum. Second antennæe attached far behind first pair.

Gnathopods imperfectly subchelate, carpus never shorter than propodus; second pair longer and more slender than first. First and second pereiopods with very large merus; dactyl slender and elongate.

Telson generally very deeply cleft.

\section{Ampelisca Kröyer.}

First coxal plate scarcely deeper than second, often concealing the base of second antennæ; fourth obliquely truncate below posterior angle.

Eyes four, or none; simple.

Mandibular palp with second joint flattened and third joint linear and rather short. First maxillæ with outer plate transversely truncated and palp having the terminal joint gradually expanded distally and armed at the apex with several strong teeth. Maxillipeds with inner plate oval; penultimate joint of palp nearly club-shaped and scarcely half as long as the second joint.

Third and fourth pereiopods with very broad basal joint, carpus bearing a simple row of spines within hind margin; fifth pereiopods with basal joint greatly expanded and with ventral margin fringed with plumose setæ; propodus foliaceous; dactyl lanceolate. 
Terminal uropods reaching considerably beyond the others; rami foliaceous, inner one broader than outer one.

Telson oblong, cleft nearly to base.

\section{Ampelisca macrocephala Lilljeborg.}

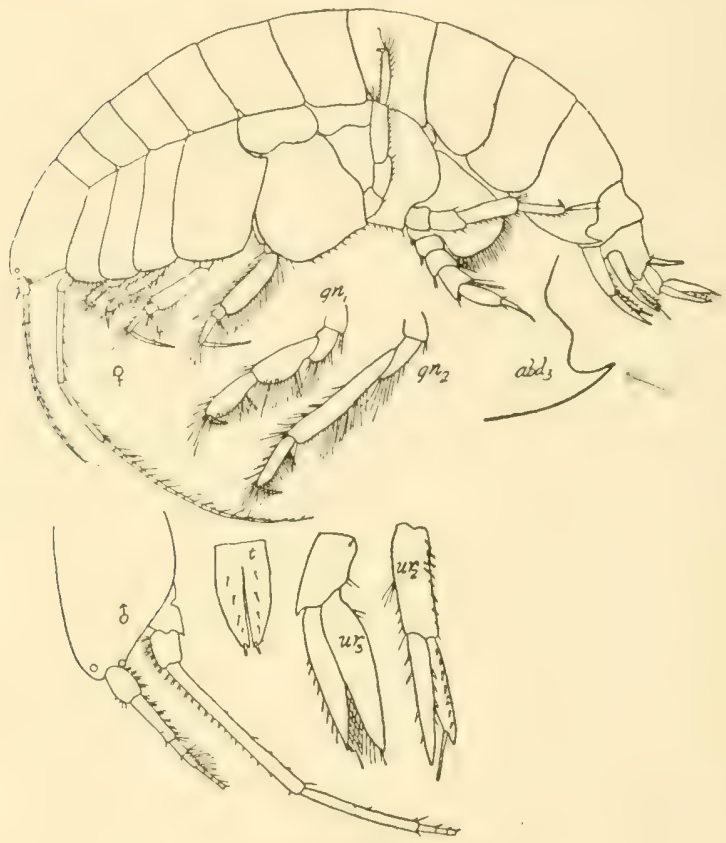

FIG. 8. Ampelisca macrocephala.

1852. Ampclisca macrocephala, Lilljeborg, Öfvers. af $\mathrm{Kgl}$. Vet. Akad. Förhandl., p. 7.

1895. Ampclisca macrocephala, G. O. Sars, Crust. Norway, vol. I, p. $x 72$, pl. 60 , fig. I.

Head about as long as first three thoracic segments, frontal part produced and obliquely truncated at the tip.

Eyes simple, two pairs, surrounded by bright red pigment in life; lower pair of eyes at antero-lateral angle of head.

First antenne in female extending as far as peduncle of second pair; flagellum, twice as long as peduncle; in the male considerably longer. Second antenne of female scarcely more than 
half the length of body, last segment of peduncle shorter than preceding one.

First pair of coxal plates widened distally and extending as far forward as the eyes. Propodus of first gnathopods oblong and not as wide as carpus, but about as long. Second gnathopods with very elongated carpus and propodus only half as long as carpus.

First and second pereiopods with dactyl considerably longer than the two preceding joints combined. Last pereiopod with basal joint broadly rounded below; ischium broader than long; merus produced into a pointed setose lobe at lower posterior angle; carpus heart-shaped with three long ciliated setæ on posterior angle, which is more produced than the corresponding anterior one; propodus oblong, tapering distally, and scarcely longer than the two preceding joints combined; dactyl about as long as propodus.

Third abdominal segment having the postero-lateral angle with a long; acute, slightly upturned projection, above which is a rounded sinus followed by a rounded lobe.

Terminal uropods with rami broadly lanceolate and about twice as long as peduncle; second pair with outer ramus somewhat shorter than inner and armed near the tip with a very long slender spine. Telson oblong oval, about twice as long as broad, deeply cleft, with four pairs of dorsal denticles and a single pair of apical spines.

Color whitish.

Length $\mathrm{I} 5 \mathrm{~mm}$.

Distribution; Arctic regions; Greenland; Labrador; Iceland; British Isles; Casco Bay, Maine; Cape Ann, Woods Hole, Massachusetts; Newport, Rhode Island; North of Fishers Island in 3/2-5 fathoms, Noank and New Haven (S. I. Smith), Connecticut.

The species seems to be confined almost entirely to muddy bottoms and is abundant in eel-grass.

Ampelisca limicola (Stimp.), recorded by Verrill (Am. Jour. Sci., ser. 3, vol. Io, p. 38) from the Noank region, is probably this species, according to an unpublished drawing of $A$. limicola by S. I. Smith.

The individuals of this species agree with Holmes's description and differ from Sars's figures of Norwegian specimens in 
that the first pair of coxal plates project a little farther forward, the dactyl of the last pereiopod is as long as, or a little longer than, the propodus; and the dactyls of the first two pereiopods are a little larger.

Ampelisca spinipes Boeck.
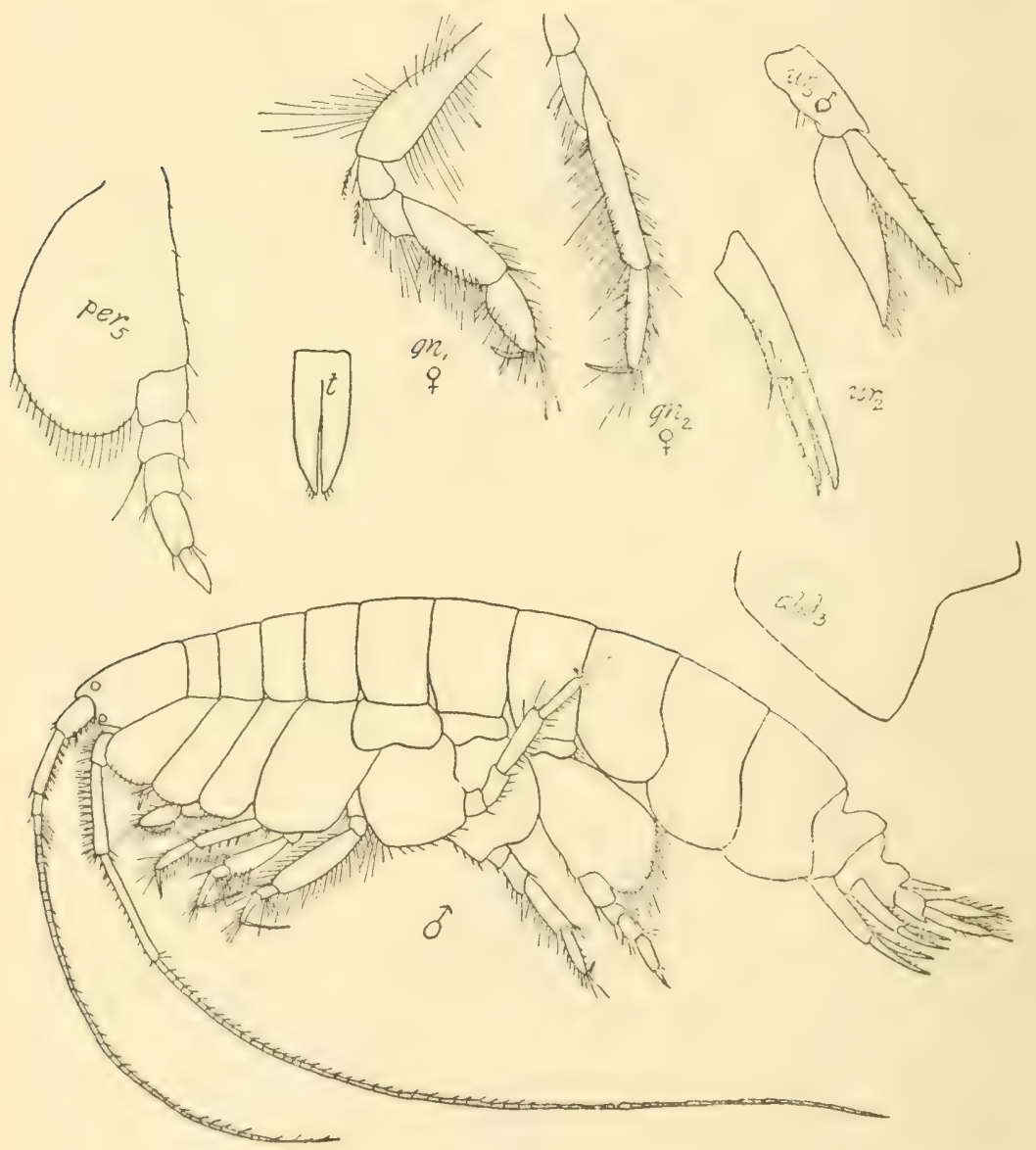

FIG. 9. Ampelisca spinipes.

I860. Ampclisca spinipes, Boeck, Förhand. ved. de Skand. Naturf., vol. 8 , p. 653 .

I891. Ampclisca spinipes, G. O. Sars, Crust. Norway, vol. I, p. $173, \mathrm{pl} .60$, fig. 2 . 
First antennæ of female slightly longer than peduncle of second pair and nearly half as long as body ; first joint of peduncle rather stout; flagellum about three times as long as peduncle, with fascicles of slender setæ; flagellum in male extremely slender and provided with very fine hairs. Second antennæ in female half again as long as the first pair, last two joints of peduncle not greatly elongated, subequal; in the male exceeding the length of body and with last joint of peduncle rather longer than preceding one.

First gnathopods with propodus nearly as long as carpus and somewhat bulging on proximal portion of posterior margin. Second gnathopods very slender, the narrow carpus nearly twice as long as propodus.

First and second pereiopods with dactyls about as long as preceding two joints combined. Last pair with ischium nearly twice as long as wide, much longer than the nearly square merus; carpus subrectangular, elongated; propodus longer than carpus or dactyl.

Postero-lateral angle of third abdominal segment not produced, forming nearly a right angle; fourth abdominal segment of male with a prominent dorsal carina which ends abruptly posteriorly; following segment deeply indented above; the corresponding features in the female are much less pronounced.

Second uropods with no long terminal spine on outer ramus. Terminal uropods thickly setose in the male but nearly devoid of setæ in female.

Telson very narrow and nearly smooth, excepting for three small marginal spinules near tip of each terminal lobe.

Color whitish, with a rose-colored or light-purplish spot in first coxal plate, and a few other spots of same color on other parts of the body.

Length $\mathrm{I}_{4} \mathrm{~mm}$.

Distribution: Norway, North Sea, France; IVoods Hole, Nassachusetts; Newport, Rhode Island; off New London, Connecticut; Fisher's Island Sound, off Stonington, Noank, off Sea Flower Key, off Saybrook (Smith), Savin Rock (near New Haven), Long Island Sound.

The species is quite abundant, being very common on sandy, gravelly, and muddy bottoms, and among eel-grass (Smith). It occurs at depths up to IO-I2 fathoms. 
It is probably the same as $A$. typica (Bate) which is recorded by lerrill (. Im. Jour. Sci. ser. 3, vol. 1o, p. 38 ) from the Noank region. Ile did not describe it but a comparison of specimens so labelled in I'eabody Museum as well as of an unpublished figure by S. I. Smith confirm this identity.

\section{Ampelisca compressa Holmes.}

ino3. Ampelisca compressa, Holmes, Amer. Naturalist, vol. 37, p. 273.

I905. Ampelisca compressa, Holmes, Bull. U. S. Bur. Fish., vol. 24 , p. 480 , pl. 6 , fig. I.

This species I have never met with either at Woods Hole or along the Connecticut coast although Holmes states that it is the most common species of Ampelisca in the Woods Hole region.

I quote Holmes' description verbatim:

" Budy strongly compressed and generally strongly flexed; head markedly shorter than first three segments of thorax; first antenne shorter than peduncle of second pair; third joint of peduncle a little shorter than first; flagellum only a little longer than peduncle, second antenne slender, over half length of body in female, and much longer than body in adult male; peduncle in male over a third length of body; last joint a little shorter than preceling one: first four coxal plates higher than their segments, the first considerably expanded below; first and second peraeopods with dactyl slender and longer than two preceding joints. l"osterior perayouds with basal joint widely expanded; ischium as loroad as long: merus with a posterior lobe extending to middle of carpus. P'ostero-lateral angle of third abdominal segment broadly rounded; fourth abdominal segment in both sexes with a prominent dorsal crest which increases in height posteriorly and carries a pair of short seta on its posterior margin; terminal uroporls similar in two sexes, furnished with only a few short spintes and setie; outer ramus of nearly same width throughout its length: telion about two-thirds as wide as long, lobes rather obtuse distally, but with inner angles subacute."

Length $6 \mathrm{~mm}$.:

Distribution: Vineyard Sound; Newport, Rhode Island; off Block Island; Long Island Sound.

It is found, according to Miss Rathbun, from the surface to lepths of 47 fathoms. 


\section{Ampelisca agassizi ( $\mathrm{Judd}$ ).}

I896. Byblis agassiwi, Judd, Proc. U. S. Nat. Mus., vol. I8, p. 599, figs. 9-II.

This species is somewhat intermediate between Ampclisca and Byblis, but agrees with the former genus in that the telson is much longer than broad and cleft nearly to the base, in the form of the last pereiopods, and in the fact that the last pair of uropods project much beyond the other ones and have no serrations on the opposing margins of the rami.

It is distinguished from other species of Ampelisca found on the New England coast by the fact that the body is not unusually compressed, the postero-lateral angle of the third abdominal segment is not produced, the telson is broad and cleft nearly to the base, and the merus of the last pair of pereiopods is produced distally nearly to the middle of the carpus behind.

The species was obtained by Mr. Judd by skimming the surface of Narragansett Bay at Newport, Rhode Island, in the summer of I 893 .

\section{Byblis Boeck.}

Corneal lens, when present, two pairs.

Antennæe slender. Mandibles rather strong; second joint of palp not expanded, third joint short. Maxillæ as in Ampclisca. Maxillipeds with inner plate narrow and truncated at tip.

Gnathopods very slender, especially the posterior ones.

Last pair of pereiopods with basal joint produced posteriorly to a very large lobe fringed on anterior and ventral margins with short ciliated setre; propodus not at all expanded, sublinear; dactyl extremely narrow and tipped by two unequal bristles.

Last pair of uropods scarcely reaching beyond the preceding pairs, rami narrowly lanceolate, not setose in female, their opposite edges being more or less distinctly serrated.

Telson short and broad and only slightly incised posteriorly.

\section{Byblis serrata Smith.} 56 I.

I874. Byblis serrata, Smith, Rep. Com. Fish. for I87i-2, p.

Eyes two pairs, simple, situated very far forward on the truncated head. 
First antennæe in male less than one-half as long as body, extending beyond peduncle of second antennæ; first joint of

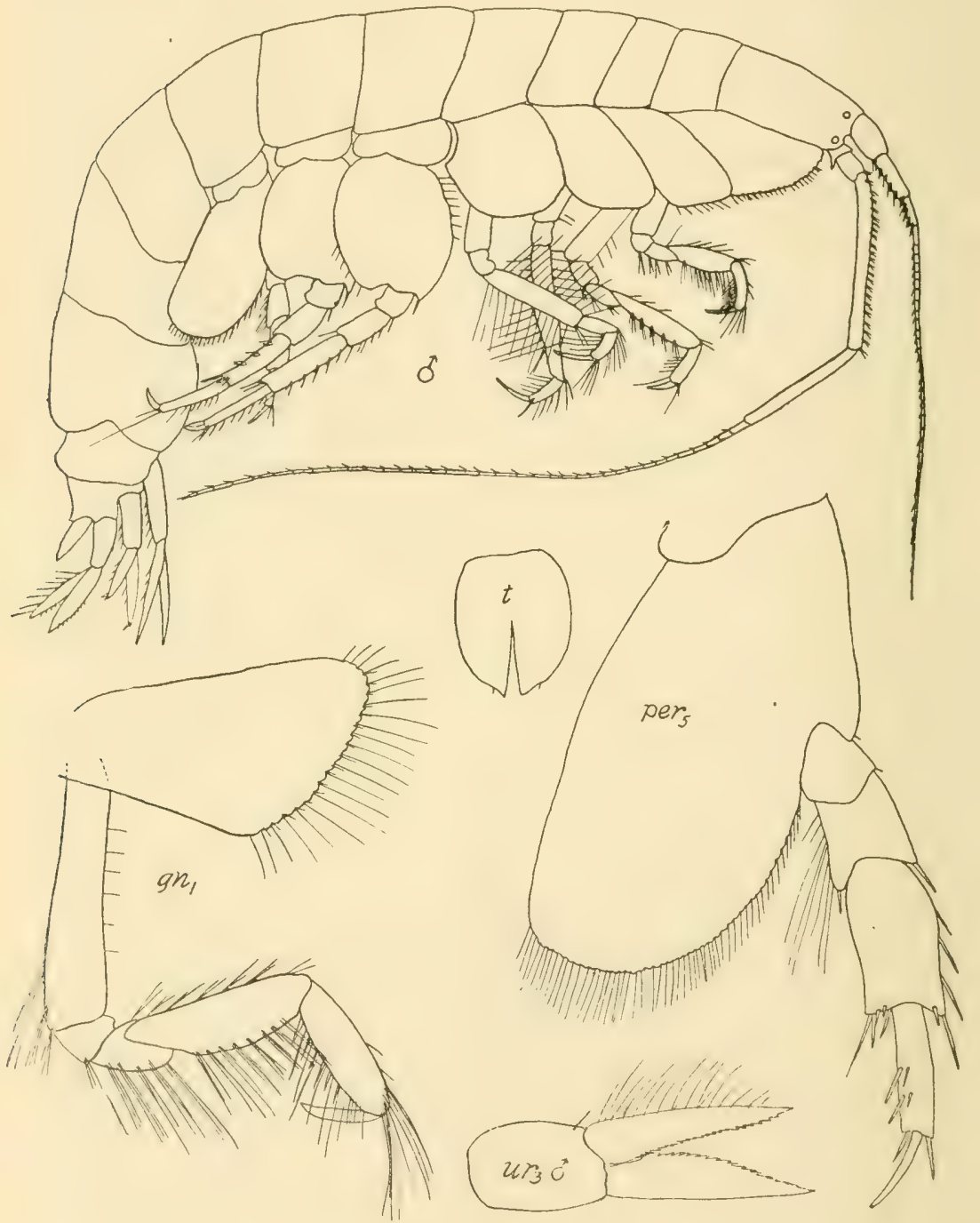

Fig. Io. Byblis serrata.

peduncle stout and shorter than second joint which is cylindrical, last joint less than one-half as long as second; lower margins of 
second and third joints with many fascicles of setæ; flagellum long and slender.

Coxal plate of first gnathopod projecting considerably anteriorly so that the mouth parts are hidden, lower margin serrate and armed with setæ; second joint very long and slender; carpus longer than the propodus which is rectangular and three times as long as broad, posterior margin with setæ and stout spines; dactyl stout.

Second gnathopods with rhomboidal coxal plate which is provided with setæ ventrally; carpus much longer than in first pair; propodus similar to that of first pair.

Fourth coxal plate incised posteriorly, about as long as high. First and second pereiopods with spinning glands; merus very long and setose; carpus and propodus short; dactyl slender and longer than propodus. Last pair of pereiopods with basal joint expanded distally, posterior margin nearly straight, ventral margin evenly curved and reaching as far as distal end of carpus and provided with a fringe of setæ; carpus as long as ischium and merus together, a little less than twice as long as broad, spinous on anterior and distal margins; propodus nearly as long as carpus, nearly four times as long as broad, with two transverse rows of spines and with distal margin having a long spine on each side of base of the long, slender dactyl.

Third abdominal segment with postero-lateral angles rounded.

Uropods biramous. First pair with equal rami, styliform and slightly longer than peduncle which bears a number of short spines dorsally. Second pair not extending as far as first; outer ramus shorter than inner. Third pair with equal rami which are longer than the peduncle and extend as far as first pair, inner margin of inner ramus provided with long setæ, outer margin serrate, outer ramus with inner margin serrate. Telson slightly longer than broad, lateral margins evenly curved and converging rapidly to the evenly rounded extremity, cleft for more than half its length.

In alcoholic specimens the coxal plates, bases of posterior pereiopods and sides of the abdomen are provided with large, irregular flecks of dark pigment.

Length IO- $12 \mathrm{~mm}$. 
Distribution: Woods Hole, Massachusetts; Newport, Rhode Island; Fishers Island, New York; Fishers Island Sound; Noank, Connecticut.

The species has been found from the surface to II fathoms in Fishers Island Sound. Professor Smith found the species off Vineyard Sound and Buzzards Bay to a depth of 20-29 fathoms on bottoms of fine compact mud and sand.

Judd in Proceedings of the U. S. National Museum, vol. I8, p. 596 , I 896 , describes the sexual differences of the species.

\section{HAUSTORIIDEE}

Coxal plates of moderate size, usually fringed with setæ; fifth coxal plate bilobed.

First antenne shorter than second, with accessory flagellum.

Mandihles with cutting edge not dentate; secondary incisive plate and molar tubercle large, palp triarticulate.

Gnathopods seldom powerful, weakly subchelate or chelate.

Pereiopods often adapted for burrowing.

Uropods all biramous. Telson flattened, more or less deeply cleft.

\section{Haustorius Statitıs Müller.}

First antenne with well developed accessory flagellum. Second antennx longer than the first; fourth joint of peduncle laminarly expanded.

Mandibles with rather large palp. First maxilla with densely ciliated flap-like expansion outside outer plate; palp well developed. Maxillipeds with inner and outer plates of nearly equal size : palp with second joint produced at end interiorly to rounded lobe, third joint bent to a right angle, fourth joint wanting.

(inathopods comparatively feeble; propodus of first simple; that of second pair forming a minute chela. Two anterior pereiopods with carlus having a rounded, lamellar expansion posteriorly. Three posterior periopods very wide. Dactyls wanting in all pereiopods.

Uropods, first pair with both rami coarsely spinous at truncated tips; second pair with rami setose; last pair with rami slender and linear, the outer biarticulate and longer than inner.

Telson broad, slightly incised in middle. 
First antenne as long as head and first two thoracic segments together; peduncle with second and third joints expanded distally and together longer than the first joint, provided with numerous plumose setx; accessory flagellum over half as long as principal one which is scarcely as long as peduncle. Second antennx longer than lirst and having the last two joints of the peduncle greatly dilated and with inferior margin strongly convex and provided with abundant plumose setae, penultimate joint much longer than last one and with a rounded distal lobe extending one-third as far as last segment; flagellum shorter than peduncle and made up of about ten segments.

Body somewhat depressed.

First four coxal plates increasing successively in size posteriorly, over twice as deep as corresponding body segments. First three tapering below to rather obtuse points; fourth one rounded below and much larger than others.

Gnathopods weak; first pair with carpus longer than propodus and dactyl, and with posterior margin evenly convex and provided with long setae; propodus simple; dactyl short. Second gnathopods very slightly longer than first, propodus very slender and chelate; dactyl very small.

Dactyls wanting in all the pereiopods. First and second pereiopods small and subequal with carpus broader than long, due to a rounded lobe on posterior margin; propodus dilated distally; third pereiopod considerably larger than second and with greatly expanded basal joint and merus and carpus dilated transversely; fourth pereiopod largest, with basal, meral, and carpal joints greatly expanded; fifth pereiopod with basal joint broader than long and with anterior and posterior margins very strongly convex, merus with a very long lobe projecting posteriorly which is armed with sharp spines and plumose setæe.

Uropods biramous; second pair smallest; teminal pair not projecting quite as far as first pair, outer ramus biarticulate. Telson short and broad, strikingly bilobed, with setæe on distal and outer margins.

The color according to Bate is pale grayish yellow, resembling somewhat closely the sand in which it lives.

Length I8 $\mathrm{mm}$.

Distribution: Georgia to Cape Cod. Specimens have been found at New Haven, Connecticut. 
This species occurs on sandy shores, where the animals burrow near low-water mark with great dexterity, being by far the most rapid burrowers among the Amphipoda. It is also occasionally found under stones in sandy places, and is dredged in shallow water.

It can not easily be confused with any other Amphipod because of its broadly expanded pereiopods devoid of dactyls.

\section{PHOXOCEPHALID王.}

Rostrum projecting like a hood over bases of antennæ.

Coxal plates rather large.

First antennæ with accessory flagellum well developed.

Mandibles with cutting edges distinctly developed, molar tubercle not large; palp large. First maxillæ with inner plate small, palp uni- or biarticulate. Maxillipeds, with plates small and palp large.

First and second gnathopods generally similar in form, subchelate, large. Fourth pereiopod the longest.

Terminal uropods often varying sexually, outer ramus the longer, biarticulate.

Telson deeply cleft.

\section{Phoxocephalus Stebbing.}

Head with acute hood.

First antennæe shorter than second which in the male are very elongated and slender and bear calceoli on the flagellum.

Mandibles with molar tubercle distinctly developed; palp well developed. First maxillæ with very small uniarticulate palp. Second maxilla with the plates nearly equal. Maxillipeds with outer plate scarcely larger than inner; palp with fourth joint slender.

Gnathopods unequal, the posterior ones being the larger. Third pereiopods with basal joint laminarly expanded; last pair with basal joint very large.

Last uropods in female with inner ramus naked and much shorter than outer; those in male much larger with both rami well developed, lanceolate, furnished marginally with ciliated setæ.

Lobes of telson narrow. 


\section{Phoxocephalus holbölli (Kröyer).}

1S+2. Phoxus holbölli Kröyer, Naturh. Tidsskr., vol. 4, p. I 5 I.

I88S. Phorocephalus holbülli, Stebbing. Rep. Voy. Challenger, vol. 29, p. I717.

ISo) I. Phorocephalus holbülli, G. O. Sars. Crust. Norway, vol. I, p. I44, pl. 49.

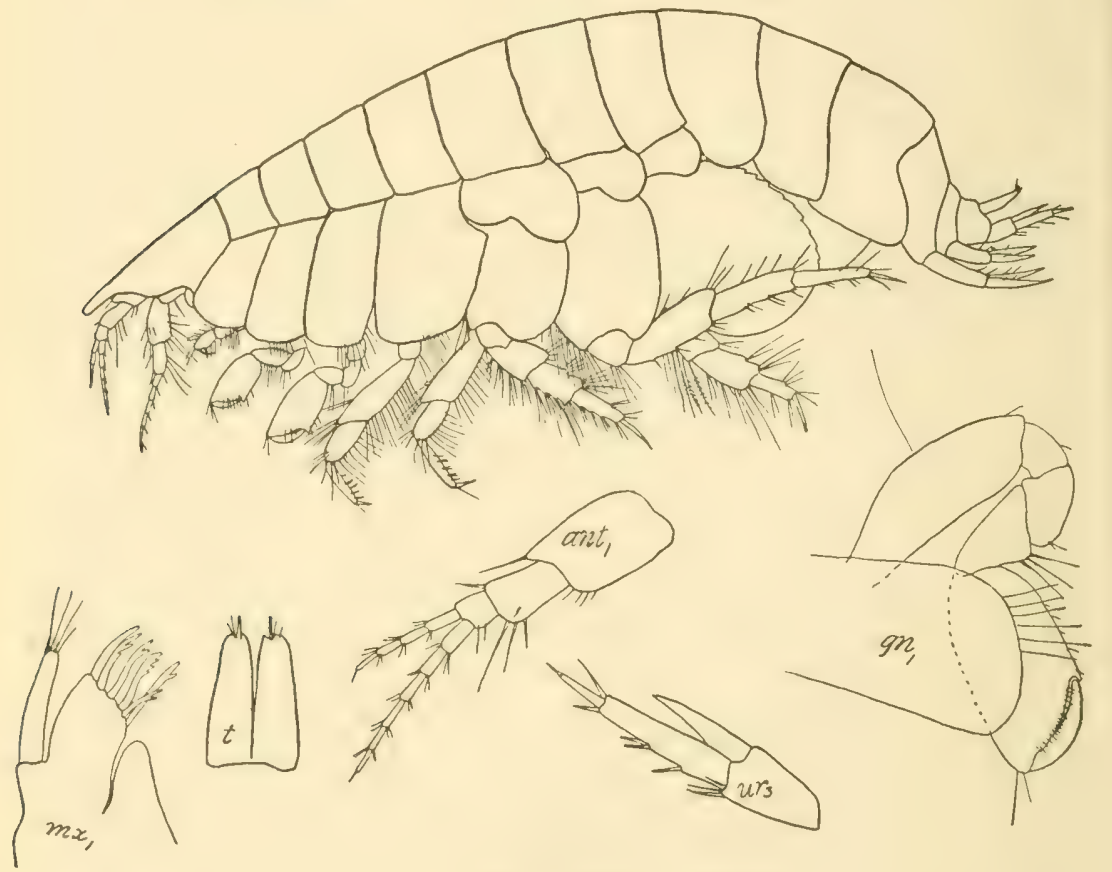

FIG. I2. Phoxocephalus holbölli.

Body smooth, IIead produced forward to form an acute, triangular hood over antennæ; eyes poorly developed, inconspicuous.

First antenne with first joint of peduncle thick and longer than sccond and third together, and with a triangular process distally; principal flagellum 6-jointed; accessory flagellum 3jointed. Second antennee with penultimate joint of peduncle enlarged distally and considerably longer than last joint and armed with many long setæe and several spines; flagellum 6- 
jointed in female, with first joint as long as second, third, and fourth together.

Coxal plates of first and second gnathopods rectangular, higher than wide, with several long setæ on posterior portion of lower margin.

Gnathopods of same form except the carpus of first is longer than that of second; propodus of second slightly longer than that of first, oblong in form but slightly broader distally, palm oblique and convex, separated from hind margin by prominent triangular process and spine; carpus with three setæ on hind margin.

Third pereiopod with basal joint broader proximally than distally and with front margin slightly concave; fourth pereiopod about one-half as long as body, basal joint provided with numerous setæe on anterior margin; fifth pereiopod with basal joint as long as rest of limb and as broad as long, posterior margin strongly convex and finely serrate.

Postero-lateral angle of third abdominal segment narrowly rounded.

Uropods biramous with rami narrowly lanceolate. In female, terminal uropod with inner ramus scarcely half as long as outer, second joint of outer less than half the length of first; in male, rami nearly equal, plumose, outer ramus with three spines on outer margin. Telson much longer than broad, cleft to the base, narrowed distally, with two spines and a seta on each rounded apex.

Color light buff or orange.

Length $5 \mathrm{~mm}$.

Distribution: Arctic regions; North Atlantic coast of Europe; Greenland; Labrador; Grand Manan; Bay of Fundy; Casco Bay; Vineyard Sound in deep water (Smith) ; Newport, Rhode Island; Long Island Sound. Low water to 45 fathoms.

\section{Paraphoxus G. O. Sars.}

Hood evenly vaulted, not carinated.

Antennæe in female nearly equal-sized; second ones in male not very elongated, flagellum very slender, provided with calceoli.

Mandibles with very poorly developed molar tubercle; palp extremely slender. First maxillæ with palp larger than in Phoxocephalus but still-uniarticulate. Second maxillæ with inner lobe 
smaller than outer. Maxillipeds with inner plates obtusely rounded at tip ; third joint of palp oval; fourth joint very slender and curved.

Gnathopods exactly alike in size and form, propodus oval, constricted at base. Pereiopods as in Phoxoccphalus.

Last pair of uropods dissimilar in the two sexes, comparatively simple in the female with inner ramus much shorter than outer; in male much larger, with both rami well developed and fringed with ciliated setæ.

Telson with narrow lobes.

\section{Paraphoxus spinosus Holmes.}

1903. Paraphorus spinosus, Holmes, Amer. Naturalist, vol. 37 , p. 276.

I905. Paraphorus spinosus, Holmes, Bull. U. S. Bur. Fish., vol. 24, p. 477 .

Head produced into triangular rostrum which projects beyond the basal joint of the first antenne. Eyes large in male, much smaller in female.

First antennie very short, only slightly longer than peduncle of second antennx of male; peduncle stout; flagellum shorter than peduncle; accessory flagellum well developed. Second antennæ in male with stout peduncle and very long slender flagellum considerably more than one-half as long as body, made up of elongated segments which bear calceoli. In female the flagellum of the second antenne is scarcely longer than peduncle.

First four coxal plates gradually increasing in depth posteriorly; fourth pair much larger than the others, with hind margin incised; first to third pairs rhomboidal, with a few fine setæ on postero-ventral angle.

Gnathopods similar in size and shape; second joint rather slender; carpus longer than propodus, stouter at distal than at proximal end; propodus broader distally than proximally; palm nearly transverse and marked off from posterior margin by a triangular process which bears a spine; dactyl very slender.

First and second pereiopods subequal; merus stout and longer than carpus which is tapering and armed distally with a very long curved spine; propodus slightly longer than carpus, with three or four short spines on hind margin; dactyl very small and spine-like. 

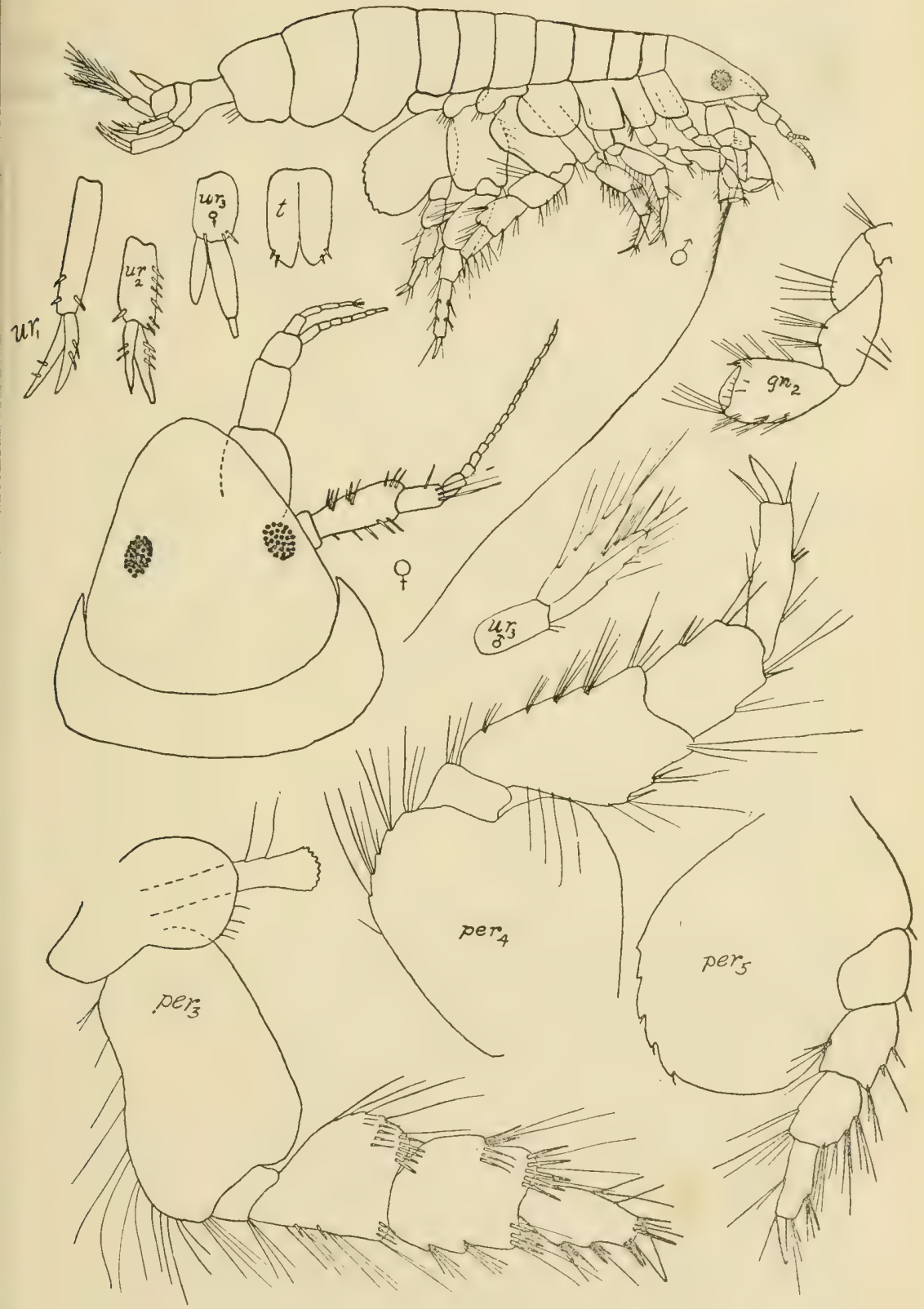

FIG. 13. Paraphoxus spinosus. 
Third pereiopod stout with basal joint well expanded and subrectangular in form; fourth, fifth, and sixth joints very stout, and subequal in length, dactyl very small. Fourth pereiopods also stout; basal joint broader than in preceding appendage and more rounded; propodus much longer than carpus. Fifth pereiopod somewhat smaller than preceding two; second joint broadly expanded posteriorly and with hind margin dentate.

Posterior margin of lateral expansion of third abdominal segment furnished with a few setæ.

First uropod with peduncle long and slender and provided near distal end with a few spines; rami styliform and somewhat shurter than peduncle. Second uropod shorter and stouter than first with peduncle and rami provided with numerous spines. Third uropod extending beyond others; peduncle short; rami in male subequal and laminar, provided on margins with numerous plumose setx, outer ramus with short distal joint. In female outer ramus much larger than inner and biarticulate without plumose setæ.

Telson subrectangular, incised nearly to base; lobes evenly rounded and provided toward lateral aspect with two very short spines.

Length $4.5 \mathrm{~mm}$.

I)istribution: Newport, Rhode Island (S. D. Judd); off Stonington, Noank, Noank Harbor (surface), Connecticut; Long Island Sound.

\section{STENOTHOIDE.}

Similar to the Metopidæ except as follows: Mandibles without molar tubercle or palp. First maxilla with biarticulate palp. Maxillipeds with inner plates small; outer plates obsolete.

\section{Stenothoe Dana.}

Coxal plates of moderate size except fourth which is greatly produced posteriorly and covers to a great extent the succeeding pairs.

Antenne elongated and as a rule subequal in length.

Mandibles without palp and with molar tubercle obsolete. First maxillæ with palp large and biarticulate. Maxillipeds with 
inner plates small and narrow; palp elongated, with unguiform fourth joint finely ciliated inside.

First gnathopods as a rule much smaller than second and subcheliform. Third pereiopods with basal joint linear, merus of last two pairs laminarly expanded.

Last pair of uropods elongated.

Telson well defined, squamous, entire.

Stenothoe cypris Holmes.

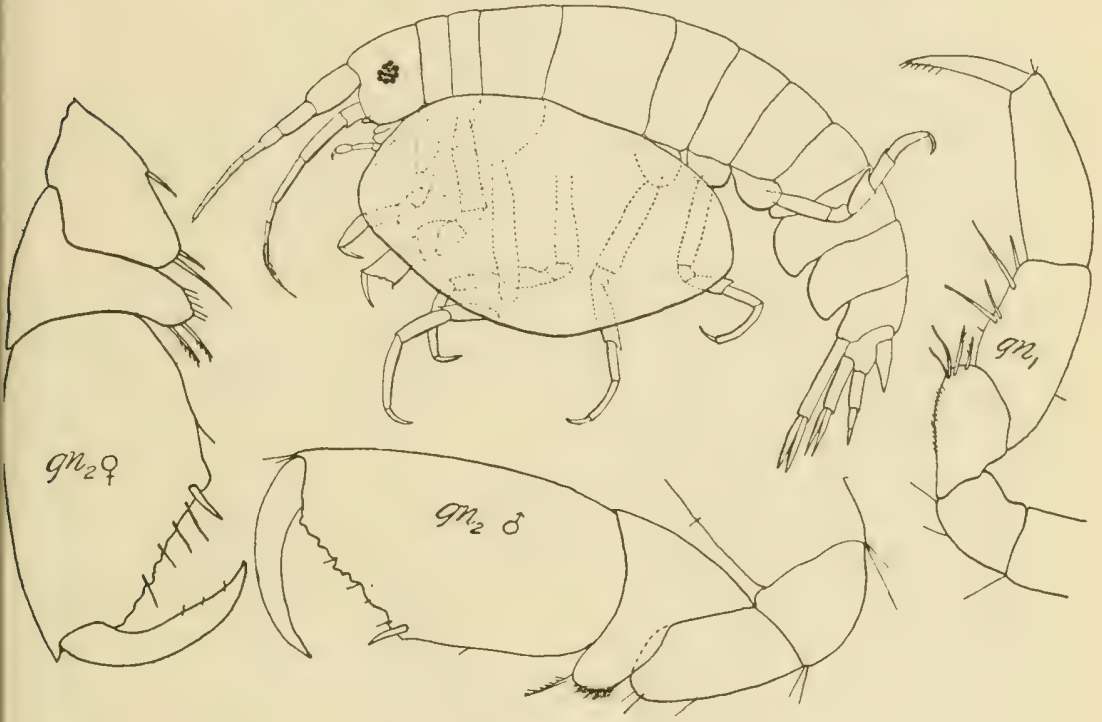

FIG. I4. Stenothoe cypris.

1903. Stencthoe cypris, Holmes, Amer. Naturalist, vol. 37, p. 278 .

1905. Stenothoc cypris, Holmes, Bull. Bur. Fish., vol. 24, p. 484 .

Eyes round and deeply pigmented in alcoholic specimens.

Antenna subequal in length and about one-third the length of body; first pair with first joint of peduncle very stout and nearly as long as next two joints; flagellum about as long as peduncle and made up of about six joints, the first of which is as long as the last joint of peduncle. Second antenna with long slender peduncle having last two joints subequal and third joint of 
peduncle not much longer than broad; flagellum of about six joints.

First gnathopods simple; basal joint long and slender with short sctie on outer margin; merus widened and rounded distally with distal half of posterior margin provided with short setæ and two pectinate spines; carpus shorter than propodus and of uniform diameter; propodus slightly tapering. Second gnathopods larger than first, with well developed oval coxal plate; basal joint slightly longer than that of first pair; merus broader at distal than at proximal end and with hind margin much longer than anterior one; carpus broader than long and with a narrow rounded lobe bearing a few pectinate spines projecting posteriorly farther than preceding joint; propodus oblong, widest behind the palm which is quite oblique and bears a stout spine near hind margin.

First pereiopods with well developed oval coxal plate as large as that of second gnathopod. Coxal plate of next pereiopod enormous, equalling the first six segments in length, oval in outline, much broader than deep. Coxal plates of succeeding pereiopods small and rounded.

First uropodis with peduncle nearly twice as long as the subequal. lanceolate rami; second pair not reaching as far as the first pair and with peduncle slightly longer than the subequal lancelate rami. Third pair with peduncle equal to the single ramus which is composed of two tmequal segments. Last two abdominal segments fused.

Telson entirc, acute.

Ifolmes states in his description that the coxal plate of the first gnathopod is well developed and that of the first perciopod is small. This is evidently an error for in specimens from Long Istand Sound the condition is reversed, the coxal plate of the first pereiopod heing well developed and that of the first gnathopod very small.

I quote Holmes' description of the color and habits of the species:

"Body pellucid ; first segment more or less rose-colored above, a row of rose-colored or sometimes brownish spots or bars along middle of back; cyes rose-colored; joints of peduncle of antennæ yellowish at tip; a dark bar across tip of abdomen and base of 
uropods; gills with a tinge of rose color. . . . This species swims in an irregular, jerky manner and after swimming but a short distance suddenly stops, flexes the body, and drops to the bottom. Its motions in the water resemble those of the ostracod, Cypris."

\section{Length $2 \mathrm{~mm}$.}

Distribution: Woods Hole, Massachusetts; Long Island Sound.

Holmes obtained this species in material secured from piles at Woods Hole in September and also among masses of Pennaria.

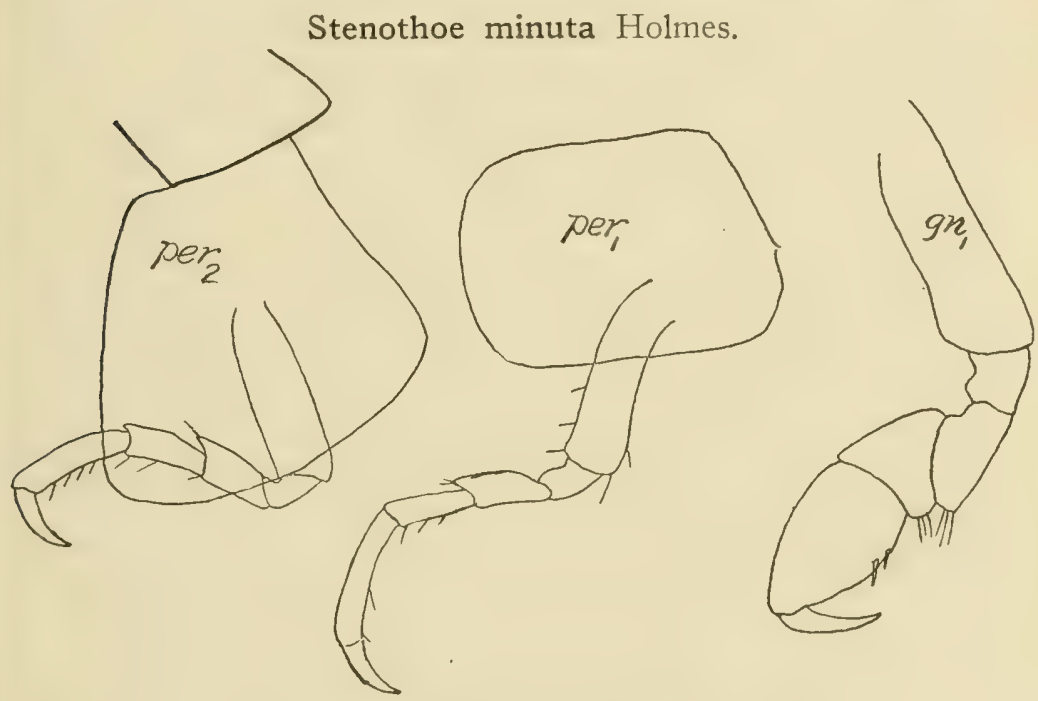

FIG. I5. Stenothoe minuta.

I903. Stenothoe minuta, Holmes, Amer. Naturalist, vol. 37, p. 278 .

1905. Stenothoe minuta, Holmes, Bull. Bur. Fish., vol. 24, p. 485 .

Eyes round.

Antennæ subequal in length and a little over one-half as long as body; first joint of first pair very much thicker than second and nearly as long as second and third; flagellum slender, about twelve-jointed. Second antennæ with last two joints of peduncle of nearly equal length; flagellum with somewhat fewer joints than first pair. 
First gnathopods with coxal plates small; basal joint with a few slender spines on anterior margin; merus rounded below, where it is furnished with four spine-like setæ and several much shorter ones; carpus produced posteriorly into a rounded lobe which has about three large spine-like seta at its distal end; propodus nearly twice as long as wide, palm very oblique and minutely pectinated like inner margin of dactyl. Second gnathopods larger than first; coxal plate large; basal joint more or less sigmoid; merus produced below into stiff setæe and three large spines at the tip; propodus widest across distal end of palm which is oblique, only slightly curved, not pectinated, and armed at distal end with two or three pairs of spines. Pereiopods of subequal length; posterior pairs with basal joints considerably expanded, and merus rather broad and produced downward at postero-inferior angle; dactyls of all pereiopods large. Fourth coxal plate not unusually large for the genus, scarcely ovate.

First uropods long and slender with lanceolate rami subequal and nearly equal to peduncle; outer ramus of second uropods markedly shorter than inner; the single ramus of terminal uropods about as long as peduncle, with proximal joint a little shorter than conical terminal one and armed with a spine at distal end of upper margin; peduncle with a spine above near middle and a spine at distal end. Telson flattened, oblong, pointed, entire, with three small spines near lateral margins.

Color pellucid, marked with scattered reddish-brown spots.

Length about $2.5 \mathrm{~mm}$.

Distribution: IVoods Hole, Long Island Sound. Holmes found it among seaweed and on piles.

\section{CEDICERID正.}

Eyes, when present, usually contiguous above.

First antenne with accessory flagellum absent or rudimentary. Mandibles with palp usually large.

First gnathopods subchelate. Second pair subchelate or rarely chelate. Last pereiopods very large with dactyl styliform.

Uropods commonly extending back to the same distance. Telson small, entire. 


\section{Monoculodes edwardsi Holmes.}

I903. Monoculodes edruardsi, Holmes, Amer. Naturalist, vol. 37 , p. 275.

1905. Monoculodes edzuardsi, Holmes, Bull. U. S. Bur. Fish., vol. 24 , p. 487.

Eyes nearly contiguous above and situated in front of base of rostrum, which is triangular and curved downwards.

First antennæ without accessory flagellum, shorter than second pair.

Mandibles with second joint of palp bent inwards and about as long as third joint. First maxillæ with inner plate suboval and bearing two setæ at tip; first joint of palp longer than broad, second joint spatulate. Maxillipeds with inner plate small and oblong, not reaching the distal end of first joint of palp; outer plates reaching only a little beyond the middle of the broad second joint of palp.

First gnathopods with carpal lobe long and distally setose; propodus oval, with palm evenly convex. Second gnathopods with a slender carpal process which scarcely extends beyond the middle of the palm. Coxal plates unusually small. Anterior pereiopods with carpus prolonged into a long lobe which extends behind the short propodus. Last pair of pereiopods much longer than the preceding, with very long, styliform dactyl.

Rami of last pair of uropods a little longer than peduncle. Telson oblong and distally rounded.

Length $9 \mathrm{~mm}$.

Distribution: Wcods Hole, Massachusetts and Newport, Rhode Island:

\section{PLEUSTIDA.}

Rostrum more or less prominent. Fifth to seventh coxal plates small.

First antennæ without accessory flagellum, longer than second pair; flagellum in both pairs made up of many segments.

Mandible with third joint of palp falciform. First maxillæ with inner plate small. Maxillipeds with inner and outer plates small and not strongly armed, and with palp long.

First and second gnathopods often alike, subchelate. Third to fifth pereiopods with basal joint expanded. 
Third uropods with rami longer than peduncle, slender, lanceolate, spinulose; outer ramus shorter than inner. Telson small, entire or (very rarely) notched, boat-shaped.

\section{Sympleustes Stebbing.}

Rostrum small, coxal plates moderate.

Mandibles with molar tubercle cylindrical and with large palp, the last joint of which is falciform. First maxillæ with well developed palp slightly dilated distally; inner plate with two setæ apically. Maxillipeds with broad inner plates; outer plates small; palp with fourth joint small.

second gnathopods larger than first and more pronouncedly subchelate.

Terminal uropods elongated with inner ramus longer than outer. Telson small, entire.

\section{Sympleustes glaber (Boeck).}

I86r. Amphithopsis glaber Boeck, Forh. Skand. Naturfor., vol. 8, p. 662 .

I8j9. Sympleustes glaber, Stebbing, Ann. and Mag. Nat. Hist., ser. 7, vol. 4, p. 209.

Head projecting to form a small rostrum, lateral angles rather prominent and acute. Back evenly rounded. Eyes large and irregularly circular.

First antennæ longer than second, about two-thirds as long as body : first joint of peduncle large, cylindrical, bearing a tooth-like process on ventral distal angle: second and third segments shorter than first: flagellum long and multiarticulate. Second antennxe with last two joints of peduncle equal in length; flagellum long and slender.

First four coxal plates deeper than wide and increasing in height posteriorly, first three with small tooth-like projection at postero-inferior angle; fourth rather deeply incised posteriorly. Fifth, sixth, and seventh coxal plates low.

First and second gnathopods not very unlike in form or size, first slightly smaller than second. Fourth joint with small triangular process at postero-distal angle and with distal margin provided with several long setæ; carpus triangular, shorter than propodus and about as broad, posterior angle rounded and with 
many slender setæ; propodus irregularly oval, palm convex and considerably longer than posterior margin, provided with several spines and numerous setæ; dactyl long and slender.

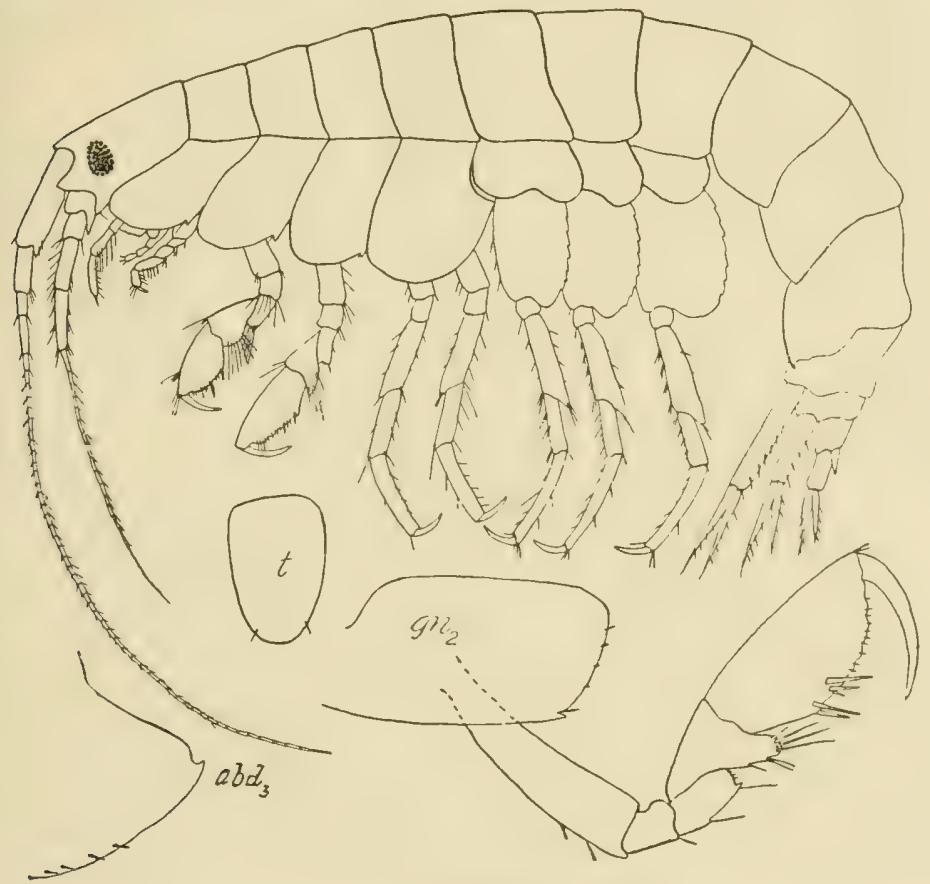

FIG. I6. Sympleustes glaber.

Pereiopods subequal in length; third, fourth, and fifth with second joint expanded with posterior margin well rounded and serrate. Fourth joint of last 3 pereiopods with postero-distal angle acute; sixth joints longer than the corresponding ones of first and second pereiopods.

Third abdominal segment with postero-lateral angle in form of a small slightly upturned tooth with a concavity above it.

First uropods slender, with peduncle considerably longer than rami which are acuminate, dorsal margin of peduncle and rami with short spines; second uropods of same form as first but peduncle considerably shorter, outer ramus shorter than inner; third uropods not extending as far posteriorly as second, outer ramus much shorter than inner. 
Telson small, oval, twice as long as broad and rounded distally. Length $6 \mathrm{~mm}$.

Distribution: Arctic Ocean, Greenland, Iceland, Norway, Fishers Island Sound, Long Island Sound, off Stonington, Connecticut.

\section{C.ILLIOPIIDE.}

Coxal plates not large.

First antennæe with peduncle usually short and accessory flagellum uniarticulate or wanting.

Mouth parts varying slightly from the normal.

First and second gnathopods usually feeble, subchelate.

Marsupial plates of female large and broad.

Terminal uropods with inner ramus longer than outer. Telson entire, sometimes a little notched or emarginate.

\section{Calliopius Lilljeborg.}

Antennx stout, subequal in length, both having flagella divided into numerous short and sharply defined articulations carrying large calceoli ventrally, last peduncular joint of first antennæ produced to a triangular process which also bears calceoli; accessory flagellum wanting.

Mandibles with comparatively large palp in which the terminal joint is as long as the second.

Ginathopods strong, with short carpus produced posteriorly to a setiferous lobe; propodus large with paln occupying nearly its entire length and imperfectly defined.

Last uropods scarcely reaching beyond the others, peduncle comparatively short, rami subequal and lanceolate.

Telson not incised at tip, tongue-like.

\section{Calliopius læviusculus (Kröyer).}

I838. Amphithoe leviuscula, Kröyer, Kongel. Dansle Videns-Kabernes Selikabs Skrifter, Copenhagen, vol. 7, 1). 28 I, pl. 3, fig. I3.

is;. Culliopius lariusculus, Bock, Forh. VidenskabsSelskabst, Christiania, I870, p. I97.

Ig)06. Calliopius lariusculus, Stebbing, Das Tierreich, Lief. 21, p. 296.

Eyes large, reniform. 


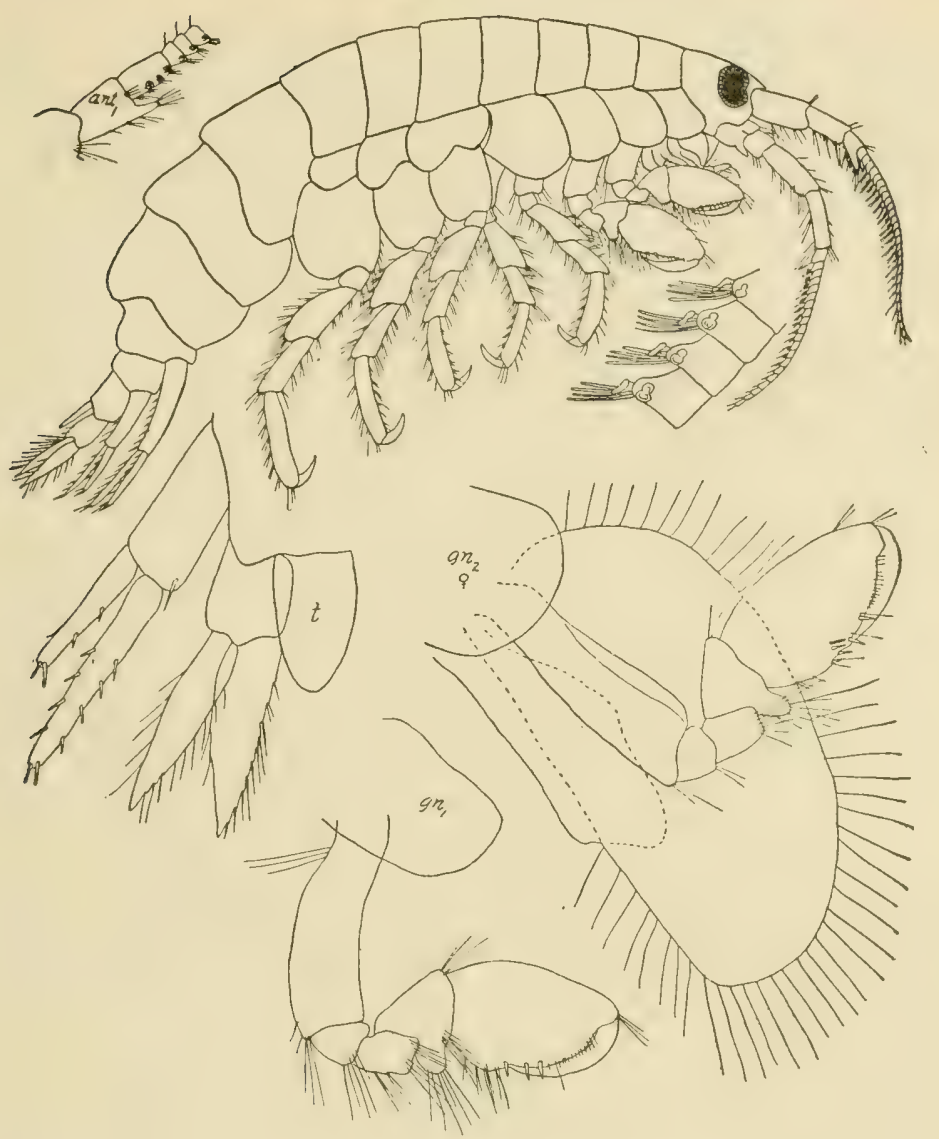

FIG. I7. Calliopius laviusculus.

First antennæ shorter than second and with first joint of peduncle considerably thicker and a little longer than second; third joint with a conspicuous triangular process projecting below flagellum and bearing about eight calceoli on lower margin ; flagellum longer than peduncle, with joints produced at antero-inferior angle and each provided with a pair of calceoli and several olfactory setæe on lower side. Second antennæe with last two joints of peduncle subequal in length, the fourth joint extending as far as the second joint of first antenna; flagellum subequal to peduncle, joints not produced below, furnished with calceoli. 
First four coxal plates deeper than broad and about as deep as their respective segments and increasing successively in depth.

First and second gnathopods of similar form and nearly equal size, the second being a trifle the larger, and with the lobe on the posterior side of carpus longer and narrower than in first; propodus ovate, palm very oblique with a row of stout spines on outer side which begins a little beyond the middle of the palm.

First two pairs of perciopods with merus strongly produced downward at anterior angle; last three pereiopods with merus strongly produced downward at posterior angle, that of last pair being more dilated than in the preceding ones.

First three abdominal segments more or less produced at posterior end to form a keel, especially developed in older specimens, and second, third, fourth, and sometimes also first depresied in front. Postero-lateral angles of second and third segments with a small tooth.

First uropods with outer ramus markedly shorter than inner which is a little shorter than the peduncle, both margins of peduncle and rami armed with numerous short spines; second uropods with peduncle relatively broader than that of first and somewhat shorter than inner ramus, outer ramus much shorter than inner; terminal uropods extending beyond the others, rami flattened, lanceolate, subequal, much longer than peduncle with both margins of each furnished with numerous spines and plumose setæ.

Telson oblong, slightly tapering and rounded at tip.

Length I $3 \mathrm{~mm}$.

Distribution: Greenland, Labrador, Inalifax, Arctic regions, Norway, British Isles, Narragansett Bay (Judd), Vineyard Sunnd (smith), Noods Hole, Gloucester, Long Island Sound.

The species is largely pelagic and is often taken in large numbers on the surface at Wroods Hole, especially in the winter.

\section{BATEIDA.}

Head strongly rostrate. First coxal plate rudimentary. First antennæ without accessory flagellum.

Mandibles with palp.

First gnathopods degraded, without propodus or dactyl. Telson cleft. 
Batea Fr. Müller.

\section{Head with strong rostrum.}

First antennæ without accessory flagellum and a little shorter than second.

Mandibles with palp. Maxillipeds with outer plates fully reaching apex of second joint of palp, fringed with spine teeth on inner margin.

First gnathopods with coxal plate rudimentary, ending with a feeble linear basal joint which is longer in female than male. Second gnathopods subchelate. Third to fifth pereiopods with basal joint expanded.

Second uropods shorter than first or third; last uropods with short peduncle and flattened rami. Telson short and deeply cleft.

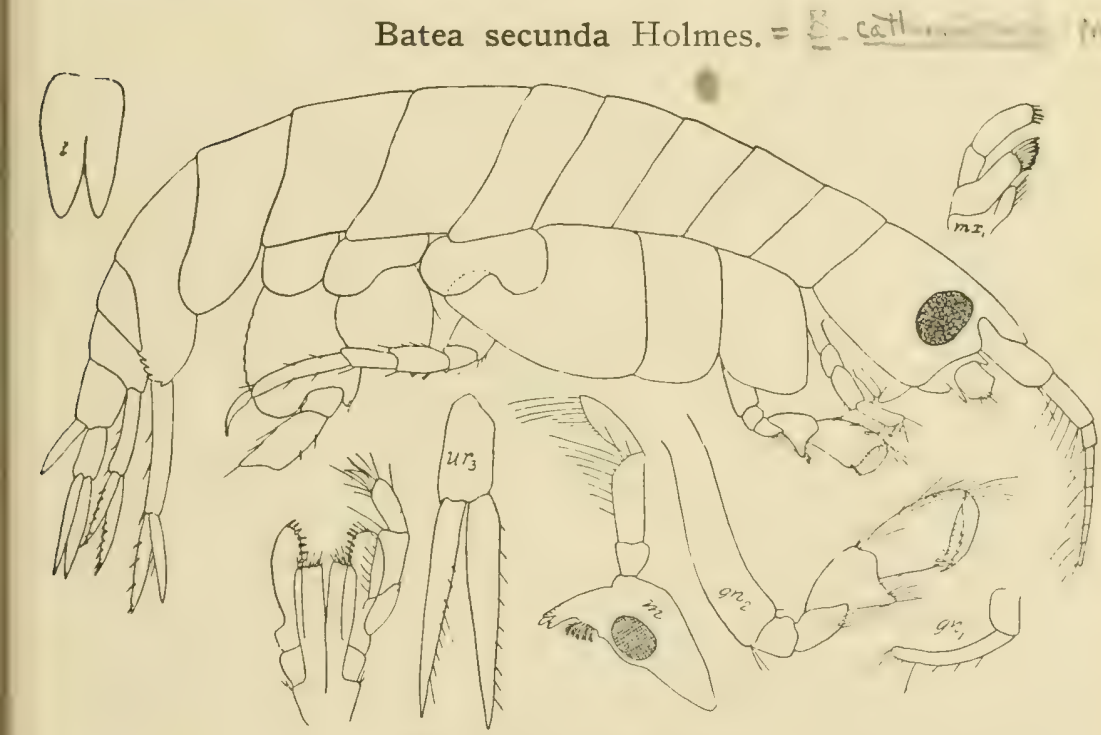

FIG. I8. Batea secunda.

1903. Batea sccunda, Holmes, Amer. Naturalist, vol. 37, p. 284.

1905. Batea secunda, Holmes, Bull. Bur. Fish. for I904, vol. 24, p. 499.

Head with a rather prominent narrow rostrum. Eyes very large. 
First antenne nearly as long as second; first joint of peduncle much stouter and a little longer than second; third joint small, less than half the length of second; flagellum consisting of about eighteen elongated segments. Second antennæe nearly half as long as body with last two joints of peduncle of nearly equal length.

First gnathopods consisting simply of a rudiment of the coxal plate and basal joint, of which the former is very small and the latter is curved and rounded distally where it is provided with a few curved sctie. Second gnathopods slender; carpus with a large, triangular posterior lobe; propodus with oblique palm, only slightly curved and minutely denticulated; dactyl with four spiniform projections on inner margin behind tip. Second, third, and fourth coxal plates about as deep as their respective segments; that of second pereiopod broader than deep and deeply excavated at upper posterior margin; the three posterior pereiopods increasing successively in length; basal joints broad; last pair considerably longer than preceding.

Posterior margin of third abdominal segment with several upturned teeth above the rounded postero-lateral angle.

First two pairs of uropods with styliform rami, and outer ramus considerably shorter than inner; second pair not extending nearly so far backward as first or third; third uropods with rami flattened, lancenlate, over twice the length of the peduncle, marins of each with short spines and setre. Telson deeply cleft.

\section{Length $5 \mathrm{~mm}$.}

Distrihution: Woods Hole, Massachusetts; Long Island Sound. Dredged at depths of 6 to 25 fathoms.

According to Holmes: "The body and coxal plates in the living specinens were marked with blue or purplish pigment spots. . . . Sometimes the blue or purplish color of these spots is replaced by a reddish lorown, and in some specimens neither kind of spots occurs."

\section{PON'TOGENEIID.E.}

Body compressed. Rostrum not prominent.

First antenne with peduncle not elongate, accessory flagellum usually wanting, never more than uniarticulate.

Mouth parts normal. 
Gnathopods with propodus not powerful, subchelate.

Third uropods with rami subequal, of moderate size. Telson deeply cleft.

\section{Pontogeneia Boeck.}

Body slender, with none of the segments produced dorsally. Antennæ slender and elongated, with the first pair a little shorter than the second and without an accessory flagellum; in the males, peduncles with calceoli.

Gnathopods subequal, feeble; carpus considerably elongated and scarcely expanded below; propodus narrow, with palm shorter than hind margin.

Terminal uropods with peduncle short, rami subequal and lanceolate. Telson unarmed and deeply cleft.

\section{Pontogeneia inermis (Kröyer).}

I838. Amphithoe inermis, Kröyer, Danske Vid.-Selsk. Afhand1. vol. 7 , p. 275, pl. 3, fig. II.

I893. Pontogeneia inermis, G. O. Sars, Crust. Norway, vol. I, p. 45I, pl. I 59 .

Body slender and compressed, with back evenly rounded throughout. Rostrum small, interantennal lobes short and obtusely rounded. First three coxal plates rounded quadrangular in form with ventral edge minutely crenulated; fourth pair considerably larger than preceding and produced posteriorly below the emargination to an angular projection.

Eyes oblong, reniform.

Antennæ in female without calceoli. First pair nearly half as long as body; first joint of peduncle scarcely longer than second but somewhat thicker; last joint half the length of second, and produced below distally to small triangular process; flagellum twice as long as peduncle and composed of numerous short articulations. Second antennæe a little longer than the first pair, with the last two joints of peduncle subequal; flagellum fully twice as long as peduncle. In male, antennæe much more fully developed than in female and with last two peduncular joints provided with large calceoli; flagellum very slender and elongated.

First gnathopods with propodus shorter than carpus and but very slightly widened distally, palm oblique, scarcely half as long as posterior margin from which it is defined by a very slight angle 


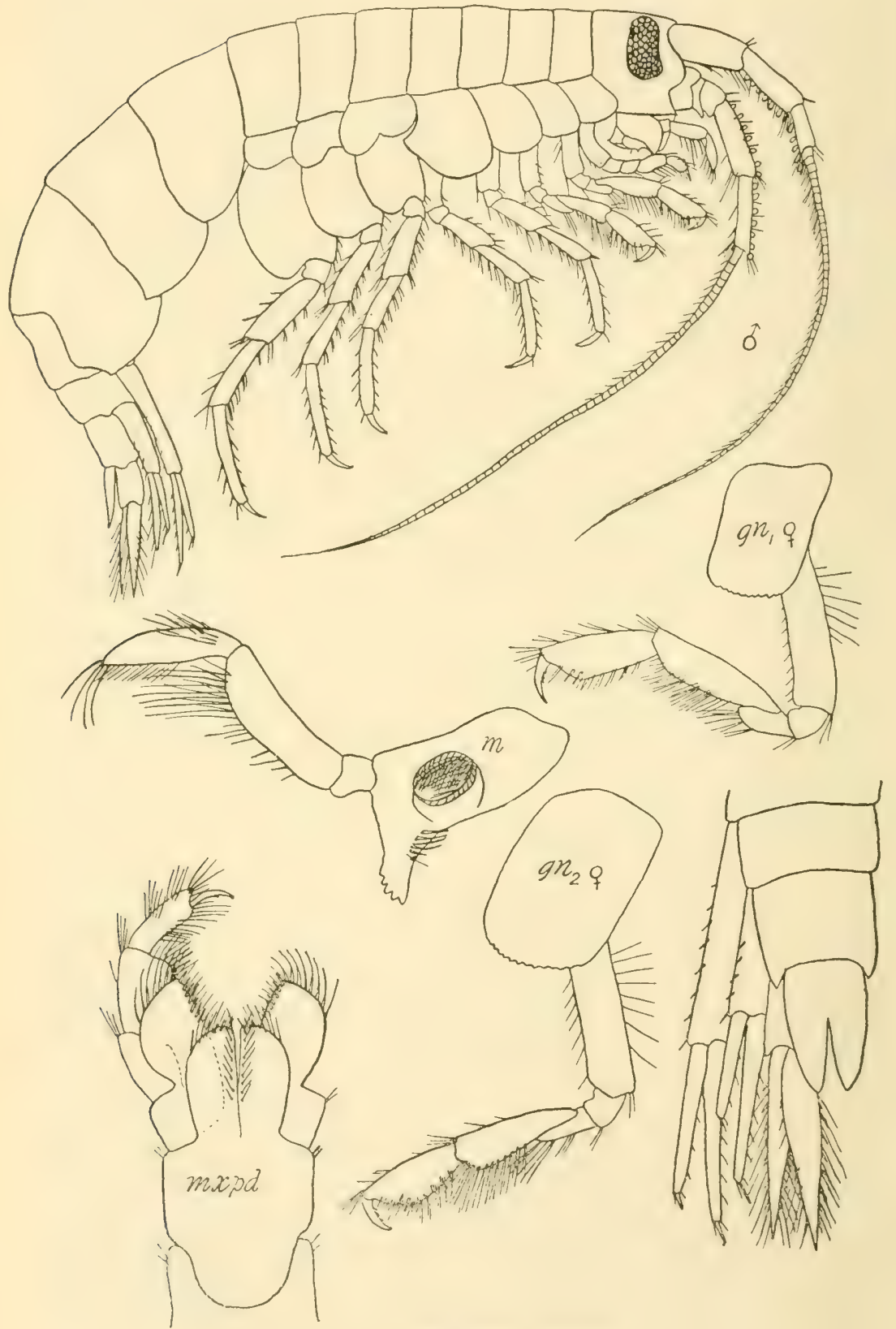

FIG. I9. Pontogencia inermis. 
armed with a transverse row of small spines. Second gnathopods scarcely longer than the first and of similar structure, except that propodus is more expanded distally. Pereiopods moderately slender and edged with fascicles of small spines; posterior three pairs successively increasing in length and with basal joint rounded, oval in form with posterior margin smooth.

Last pair of uropods projecting beyond the others; rami more than twice as long as peduncle and edged with small spinules and setæ. Telson reaching well beyond the peduncle of last uropods, oblong oval in form, cleft extending beyond the middle and gradually widening toward apex, terminal lobes obtusely pointed. The species is nearly colorless, with scattered purplish spots and the antennæ with a few transverse purplish bars.

Length II $\mathrm{mm}$.

Distribution: Arctic Ocean, Norway, Halifax, Bay of Fundy to Greenland (Smith), Grand Manan, Vineyard Sound, Long Island Sound, Fishers Island Sound.

The species is often associated with Calliopius lcviusculus according to Holmes and is found commonly in tide-pools as well as at the surface.

\section{Body slender.}

\section{GAMMARID E.}

Antennæe generally slender; accessory flagellum often greatly developed, but sometimes wanting.

Mouth parts normal.

Gnathopods generally powerful; sometimes more powerful in male than female. Pereiopods more or less slender, sometimes basal joint of pereiopods three to five only slightly expanded.

Terminal uropods with rami foliaceous and projecting beyond the others. Telson either entire or cleft to the base.

\section{Eucrangonyx Stebbing.}

Body compressed, not carinate.

First to fourth coxal plates deeper than the following ones.

First antennæ longer than the second, and with a small biarticulate accessory flagellum.

Maxillipeds with outer plates narrow.

First and second gnathopods subchelate, with propodus not strikingly broader than carpus. Third to fifth pereiopods with basal joint moderately expanded. 
Terminal uropods not elongate, with small inner ramus. Telson emarginate.

Eucrangonyx gracilis (Smith).

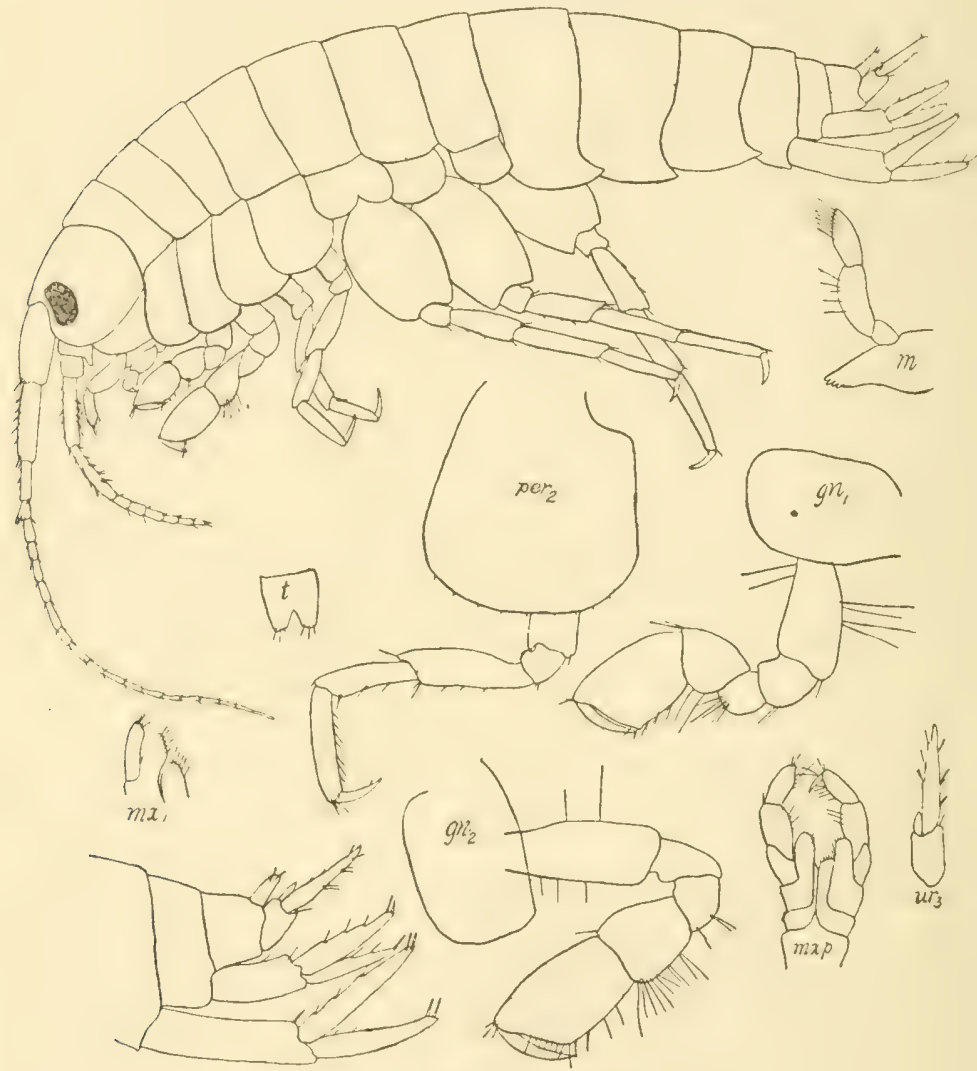

FIG, 20. Eucrangonyx gracilis.

1871. Crangony.x gracilis, Smith, Amer. Jour. Sci., ser. 3, vol. 2 , p. 453.

I899. Eucrangonyx gracilis, Stebbing, Trans. Linn. Soc. Lond., ser. 2, vol. 7, p. 423.

I907. Eucrangony.x gracilis, Weckel, Proc. U. S. Nat. Mus., vol. 32, p. 32 .

Eyes small, elongated. 
First antennæ slightly more than half as long as the body; accessory flagellum composed of two joints. Second antennæ half as long as first pair.

First gnathopods in male with propodus having palm slightly oblique; second gnathopods with propodus increasing in width distally and more elongate than in first pair, palm oblique, somewhat arcuate. Third, fourth, and fifth pereiopods with basal joints serrate and with small spines on both margins.

Postero-lateral angles of the first three abdominal segments produced and terminating in a small tooth.

Third uropods reaching apex of second pair; outer ramus nearly twice as long as peduncle, inner ramus minute, unarmed. Telson slightly shorter than peduncle of last uropods, about as broad as long, cleft about one-third the distance to the base and with two or three spines on the truncate extremities of the lobes.

Length 7-I $8 \mathrm{~mm}$.

Distribution: Lakes Superior and Huron; Irvington, Indiana; Dalaware, Ohio; Nashville, Tennessee; Providence, Rhode Island; New Haven, Connecticut.

\section{Crangonyx Bate.}

Similar to Eucrangony.x, except that terminal uropods have a single uniarticulate ramus and the telson may be entire or partly cleft.

\section{Crangonyx tenuis Smith.}

I874. Crangony.t tenuis, Smith, Rept U. S. Fish. Com., $1872-3$, p. 656 .

Body elongated and slender; coxal plates lower than their respective segments; last two abdominal segments fused. First three abdominal segments longer than last three of thorax; but fourth, fifth, and sixth together scarcely longer than third.

Eyes invisible in alcoholic specimens; interantennal lobes small, rounded, projecting.

First antennæ less than half as long as body in the male, with flagellum composed of about twenty-two segments and twice as long as the peduncle, the first joint of which is slightly longer than the second and the last joint about one-third as long as the first; accessory flagellum very small, composed of two joints, the terminal one of which is very short. Second antennæ 


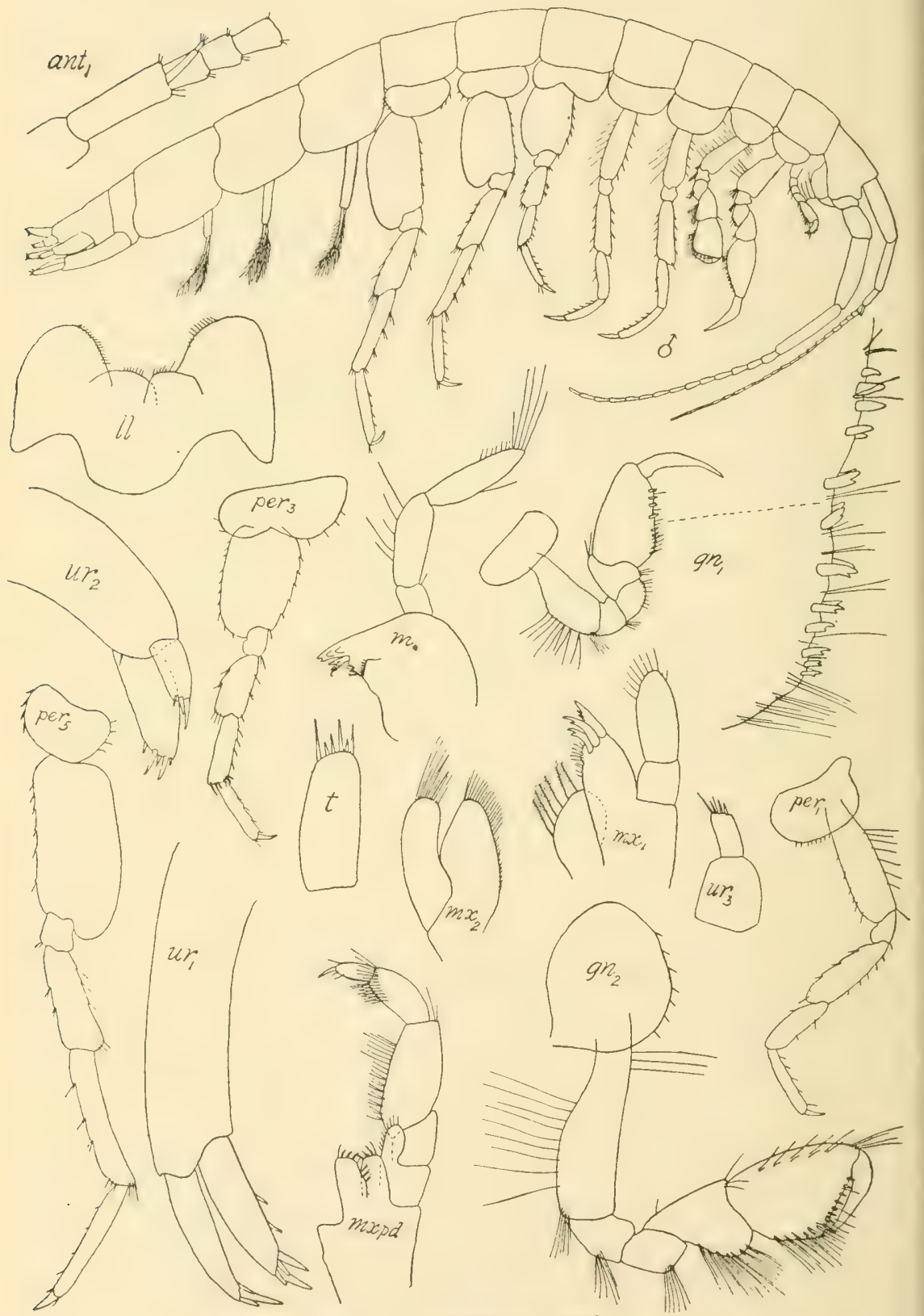

FIG. 2r. Crangony.x tenuis. 
stout and longer than first pair; last two joints of peduncle subequal; flagellum about as long as peduncle and composed of about fifteen segments.

Mandibles làrge but quite short; principal cutting edge divided into three or four teeth; secondary cutting edge likewise denticulated; molar tubercle large and close to cutting edge; palp well developed, triarticulate with last joint longer than second and provided with long setæ near the slightly pointed tip. Lower lip broad, with outer plates evenly rounded and with mandibular processes short and broad; inner plates small. First maxilla with imner plate broad and rounded, with six plumose spines on inner margin; outer plate with very oblique distal margin armed with three strong teeth and inner margin with short setæ distally; palp strong, made up of two joints of which the distal one is more than twice as long as the proximal one and armed at it $\dot{s}$ rounded apex with setæ. Second maxillæ with outer plate curved and rounded apically, inner plate broader than outer one and tapering to a rounded apex; outer plate with setæ apically; inner plate with seta at apex and on inner margin. Maxillipeds with very large palp; inner plate small, rectangular, not reaching as far as first joint of palp; outer plate with rounded apex, bearing short setre on inner and apical margins; second joint of palp very long, with abundant setæ on inner margin, third joint about half as long as first and second together and with setre at apex, fourth joint about half as long as third, slightly tapering and provided distally with a spine tooth.

First gnathopods stouter than second pair; basal joint broad, with seta on posterior margin toward distal end; carpus triangular with setæe on short, rounded posterior margin; propodus longer than basal joint, with very oblique palm extending nearly to base of joint and armed with a double row of strong, blunt spine teeth, many of which bear a notch and a cilium near apex; dactyl very long and curved. Second gnathopods with basal joints more slender than that of first pair; merus with posterior margin very convex and with a fascicle of setæ; carpus longer than in first pair with numerous fascicles of spines on hind margin; propodus broadly oval, with palm straight and not very oblique and provided with a double row of spine teeth as in first pair. First two pairs of pereiopods slender. Third, fourth, and 
fifth pereiopods increasing in length posteriorly; basal joints not greatly expanded, with front margins provided with short setæ.

Uropods all extending to about the same point; first pair with subeyual rami which are about half as long as peduncle and which bear spines apically; second pair with outer ramus about half as long as inner one, both of which are provided apically with spines; last pair small, uniramous; peduncle nearly as broad as long; ramus rectangular, about twice as long as wide and with apical spines and setæ.

Telson subrectangular, twice as broad as long, tapering slightly toward the entire and slightly arcuate posterior margin which is armed with numerous spinules.

The length of the largest males, from which the drawings in this paper were made, is about $13 \mathrm{~mm}$. The ustal length is only $6-8 \mathrm{~mm}$.

The sexual differences are not great.

According to smith, in all the females and most of the males of the smaller size mentioned, the first antennxe are longer than the second and the flagellum of the first is composed of sixteen to nineteen segments and that of the second pair of only eight to ten.

The species was originally described from specimens found in wells in Middletown, Connecticut, but specimens have also been found at Canakn, and under stones in a small brook near New Haven.

\section{Melita Leach.}

Abdominal segments sometimes produced dorsally to dentiform projections. Coxal plates moderate, fourth pair largest and more or less emarginate behind.

First antenne very slender and much longer than second; accessory flagellum well developed.

Mouth parts normal.

Ginathopods rather unequal, anterior ones being comparatively small, and the posterior ones being often enormonsly developed in the male. Tereiopods rather elongated, the three posterior pairs increasing successively in length and having the basal joint expanded.

Last pair of uropods projecting considerably beyond the others, having the rami very unequal, the inner one being very minuter. Telson small and cleft almost to base. 
Melita nitida Smith.

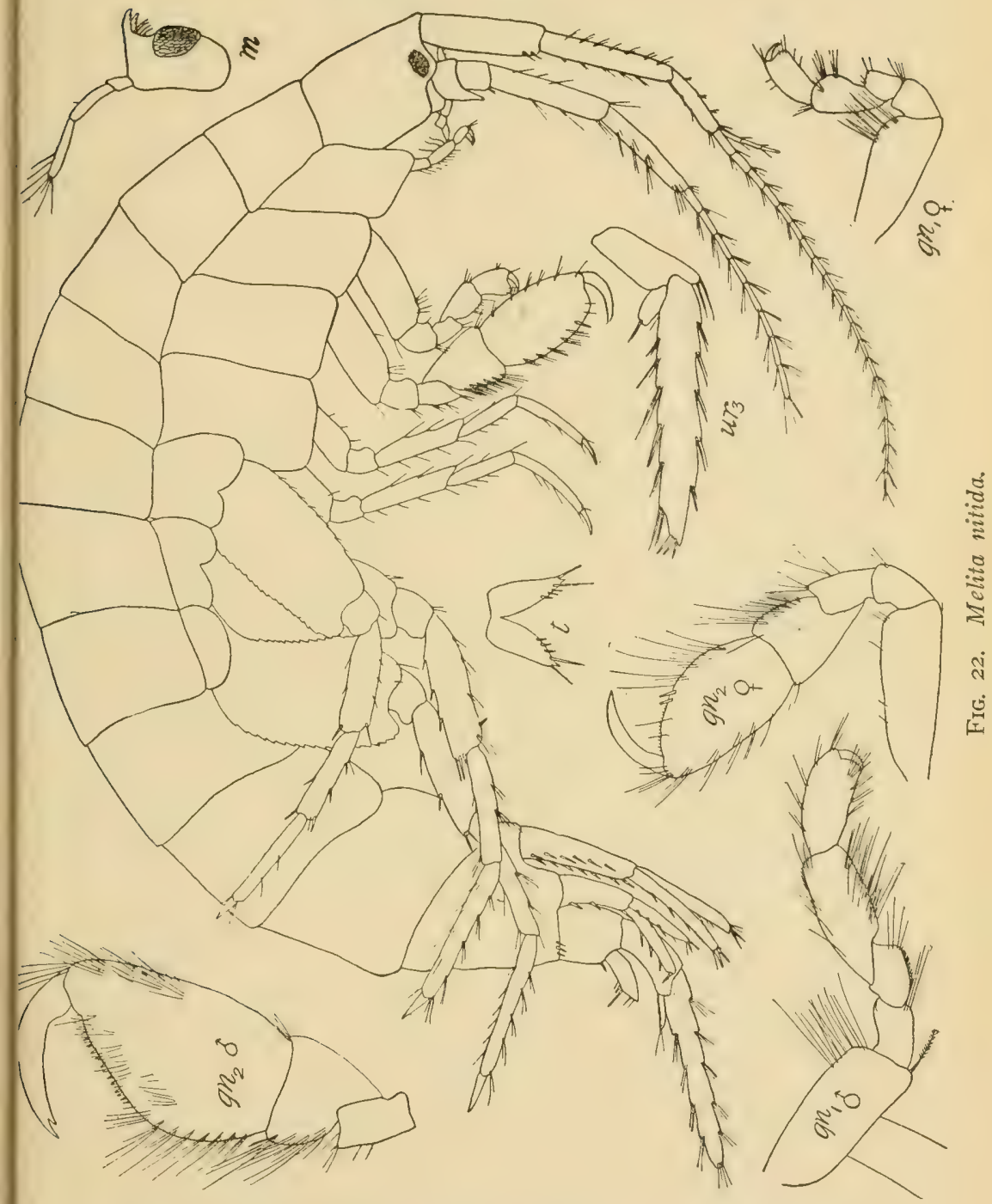

1873. Melita nitida, Smith, Rep. U. S. Com. Fish. for I87 I-2, p. 560 .

Body slender and compressed; eyes small and round.

First antenne two-thirds the length of body, with peduncle having second joint longer than first and nearly twice the length 
of third; flagellum longer than peduncle; accessory flagellum three-jointed and not longer than last peduncular joint. Second antemne shorter than first with last joint of peduncle nearly as long as preceding; flagellum shorter than peduncle, joints furnished with whorls of long setæ.

First four coxal plates deeper than their segments; first three oblong.

First gnathopods quite similar in the two sexes; carpus longer and broader than propodus which is oblong, palm about one-third the length of the nearly transverse distal margin of the propodus; dactyl short, very much curved and thick at the base, articulated at middle of distal margin. Second gnathopods in malc with large oval propodus having palm evenly convex and about as long as posterior margin with which it forms an almost continuous curve; propodus in female similar to that of male but smaller. Last three pereiopods with basal joints large, oblong, armed with short spines in front and serrated behind. Posterior margins of abdominal segments not dentate or produced; fifth segment with several spines on posterior margin on either side of mid-dorsal line.

Terminal uropods long; inner ramus minute, situated in a sinus of peduncle; cuter ramus similar to that of $M$. dentata but armed on either side with more fascicles of longer spines than in that species.

Telson with tip of lobes triangular, acute; with a few spines around tip and on distal part of inner margin.

Color dark greenish slate.

Length io $\mathrm{mm}$.

Distribution: New Jersey to Cape Cod (Smith), VVoods Hole, Massachusetts: New Haven (Smith), Noank Ilarbor, Connecticut.

The species is found under stones and among sea weed near low-water mark.

Melita parvimana Holmes.

1903. Milita purimana, ITolmes, Amer., Naturalist, vol. 3\%, p. 279 .

1905. Melita parvimana, Holmes, Bull. U. S. Bur. Fish., vol. 24, p. 506 .

This species may be distinguished from other species of II clita by the fact that the carpus of the first gnathopods is as broad as 
long, and the propodus is short and stout; the second gnathopods and terminal uropods are also smaller than in most species of this genus.

\section{Length $12 \mathrm{~mm}$.}

The species was described from a single specimen taken at Newport, Rhode Island.

Melita dentata (Kröyer).

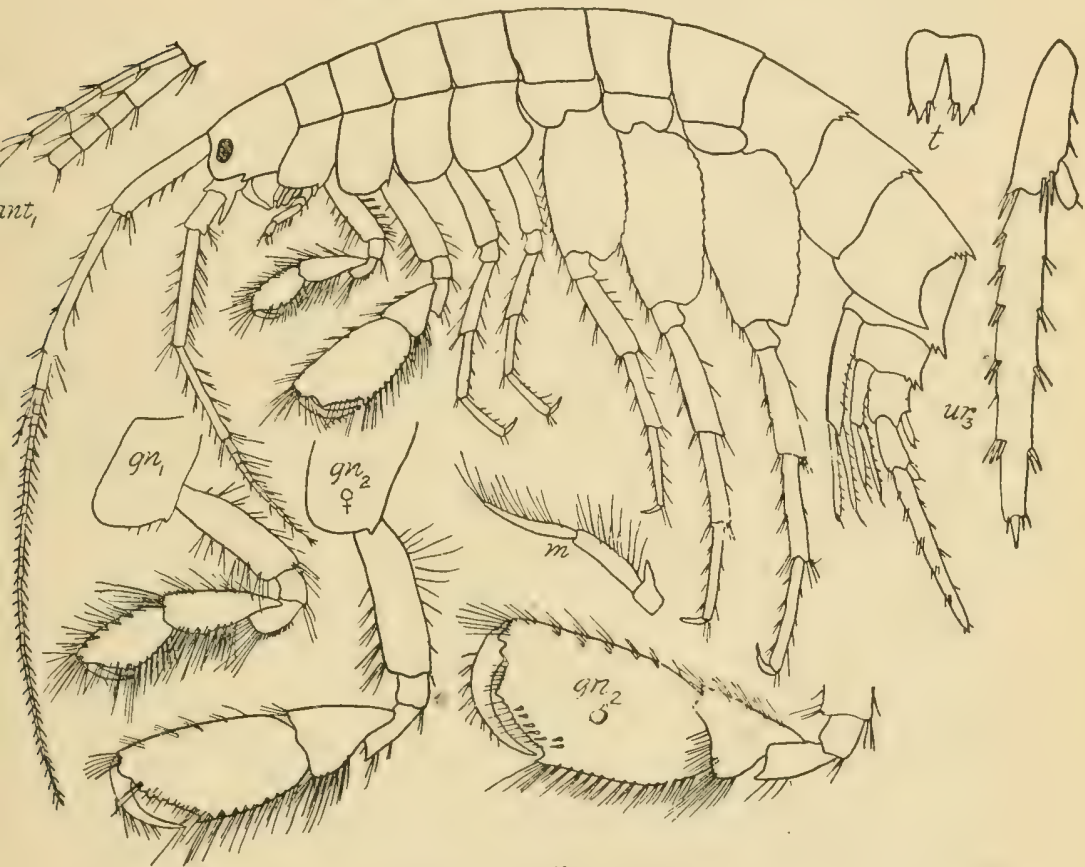

FIG. 23. Melita dentata.

1853. Gammarus purpuratus, Stimpson, Marine Invert. Grand Manan, Smithson. Contrib. vol. 6, No. 5, p. 55.

I894. Melita dentata (part), G. O. Sars, Crust. Norway, vol. I, p. 513, pl. I8I, fig. I.

I906. Melita dentata, Stebbing, Das Tierreich, Lief. 2I, p. 427.

Body much compressed; eyes round or oval.

First antennæ much longer than second; second joint of peduncle longer than first and about four times length of third; 
accessory flagellum about five-jointed. Second antennæe with long and slender peduncle having last joint a little shorter than preceding one; flagellum shorter than peduncle.

First four coxal plates deeper than their respective segments, the fourth deeper than wide; first three with small tooth at postero-inferior angle.

First gnathopods of male with carpus and propodus subequal ; merus with a tuft of very short setæe on posterior side; carpus with a similar tuft at distal end of anterior margin; propodus suhoval, with palm quite evenly convex, very oblique and contintuons with posterior margin of joint which it equals in length. Second gnathopods of male with propodus very large and strong and with oblique palm which has a large triangular tooth near distal end and is terminated proximally by a large spine tooth. In female, first gnathopods closely resembling those of male, but with a relatively longer carpus and smaller propodus. Pereiopods slender and elongated, with large, oblong basal joints which are serrated on posterior margins.

I'osterior margins of abdominal segments produced into teeth, the median one of which is the largest, that of the fourth abdominal segment being the largest of all.

Last pair of uropods elongated, with outer ramus having sides nearly parallel to near the tip and armed with several fascicles of spines on each margin; inner ramus minute.

Telson with each lobe terminating in an acute point on inner side of which is a large and a small spine and on outer a spine or seta.

Color yelluwish, with broad transwerse bands of dark reddish brown.

Length $\mathrm{i} 6 \mathrm{~mm}$.

The species is extensively distributed in the Arctic regions, Norway, Labrador, Buzzards Bay. Several specimens were dredgecl, according to Holmes, in Rhode Island waters, off Fishers Island from $71 / 2$ to 430 fathoms (Rathbun), Long Island Sound.

\section{Elasmopus Costa.}

Body strongly built and smooth. Coxal plates moderate; fourth pair being largest and distinctly emarginate behind. 
First antennæ longer than second and provided with a comparatively small accessory flagellum.

Mouth parts normal.

Gnathopods subchelate and unequal, the second pair being the larger and being strongly developed in male. Posterior pereiopods unusually robust with basal joints very large and laminar.

Last pair of uropods not much elongated, robust, with rami comparatively broad. Telson laminar and divided by a deep, narrow cleft into two halves which are spinous at the tip.

\section{Elasmopus levis (Smith).}

1874. Mara levis, Smith, Rep. Com. Fish., vol. I, p. 559.

Eyes nearly round, black.

First antennæ stout, two-thirds as long as body; first and second joints of peduncle equal in length, third joint two-thirds as long as second; principal flagellum as long as peduncle and made up of about $2+$ rather short segments; accessory flagellum less than half as long as last joint of peduncle and composed of two oblong joints and a very short terminal one.

Second antennæe slender, scarcely longer than peduncle of first; fourth and fifth joints of peduncle subequal, third joint very short, gland cone prominent; flagellum slightly longer than last joint of peduncle, made up of about eight joints.

Mandibles with three-jointed palp of characteristic form, last joint having shape of knife blade with row of setre on edge.

First four coxal plates slightly deeper than their respective segments, fourth about as broad as deep.

First gnathopods of male, with propodus oblong and subequal to carpus which is provided on posterior margin with numerous setæ, and with palm oblique and evenly convex; basus stout. Second gnathopods of male very large, carpus very short, with narrow posterior lobe furnished with dense setæ; propodus oblong and twice as long as broad, palm short, oblique, smooth, with row of four or five spines near base of dactyl, which is stout and closes against an excavation on inner side of propodus.

In the female, first gnathopods much like those of male but with palm transverse. Second gnathopods much smaller than in male, of oblong shape resembling the first gnathopods of male; dactyl slender and closing against palm. 

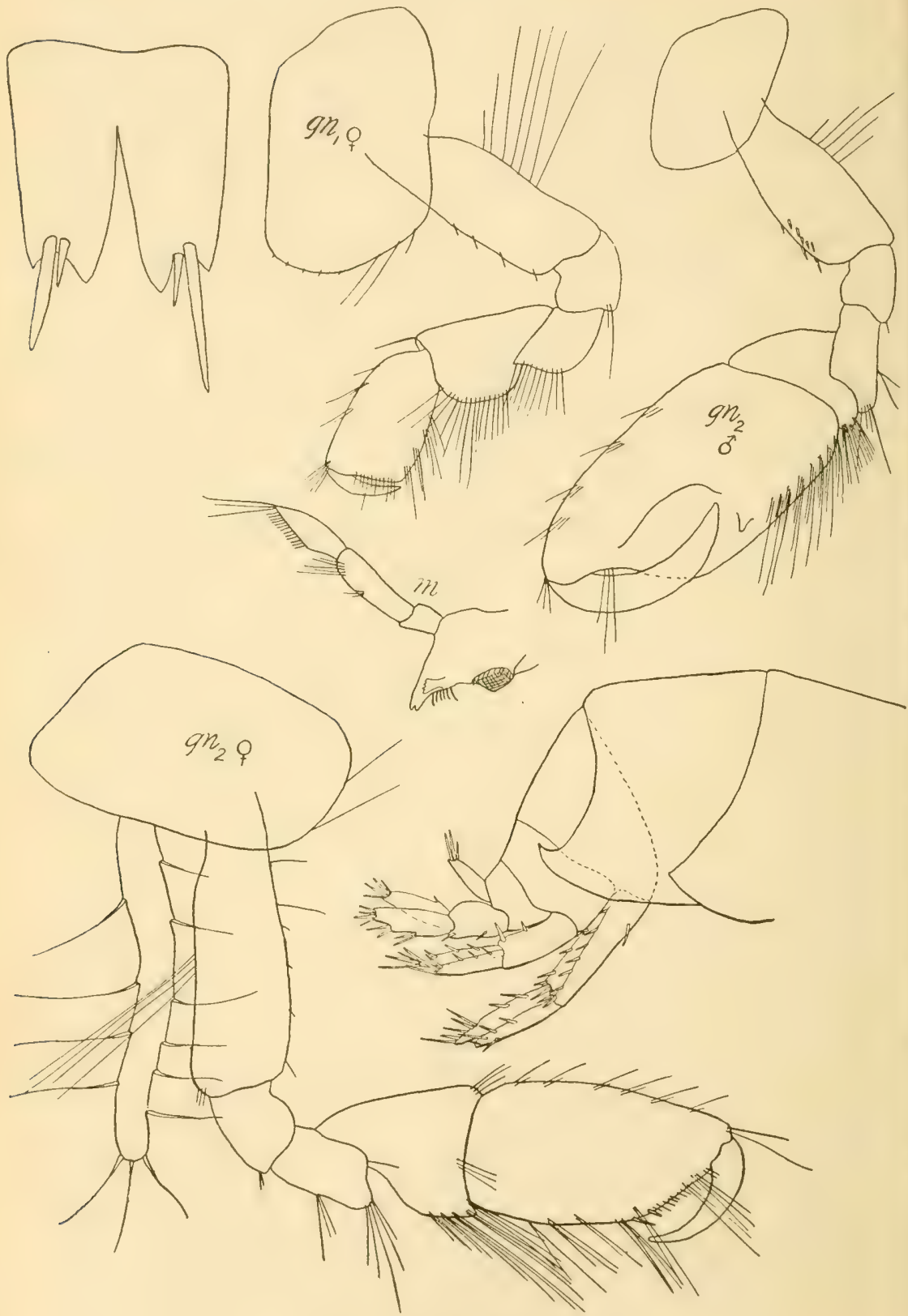

FIG. 24. Elasmopus levis. 
Last two pereiopods subequal and stout with merus and carpus considerably expanded especially in male; basus of third, fourth, and fifth pereiopods broadly oval.

Terminal uropods biramous, extending beyond the others; rami short and broad, inner one narrower than outer and slightly shorter, provided with a small spine near base of inner margin; outer ramus with three fascicles of spines on outer margin; tips of both rami truncated and armed with numerous spines.

Telson reaching to base of rami of terminal uropods, nearly as broad as long, and cleft two-thirds of the way to the base; lobes oblong and notched at the apex where there may be one or two spines.

Body olive brown to grayish, marked with numerous small rounded lighter-colored spots and a series of larger light spots along mid-dorsal line. In specimens having much gray pigment the legs are barred with dark bands which in other specimens may be scarcely visible.

Length ro $\mathrm{mm}$.

Distribution: New Jersey; Vineyard Sound; Provincetown; Woods Hole, Massachusetts; Long Island Sound; Noank, off Stonington, Connecticut.

The species is found under rocks and amid sea weed at low tide. At Noank it was also found on piles in sponges, etc., in eel-grass, and on the surface.

Females captured in August at Woods Hole were found with eggs.

\section{Dikerogammarus Stebbing.}

Agreeing in general with Gammarus; but with fourth and fifth abdominal segments each raised dorsally to a spiniferous tubercle. First antennæ longer than second and with well developed accessory flagellum.

First and second gnathopods larger in male than in female; second pair larger than first.

Dikerogammarus fasciatus (Say).

I8I8. Gammarus fasciatus, Say, Jour. Acad. Nat. Sci., Phila., vol. I, pt. 2 , p. 374 .

1874. Gammarus fasciatus, Smith, Rep. U. S. Fish. Com., I872-3, p. 653 . 


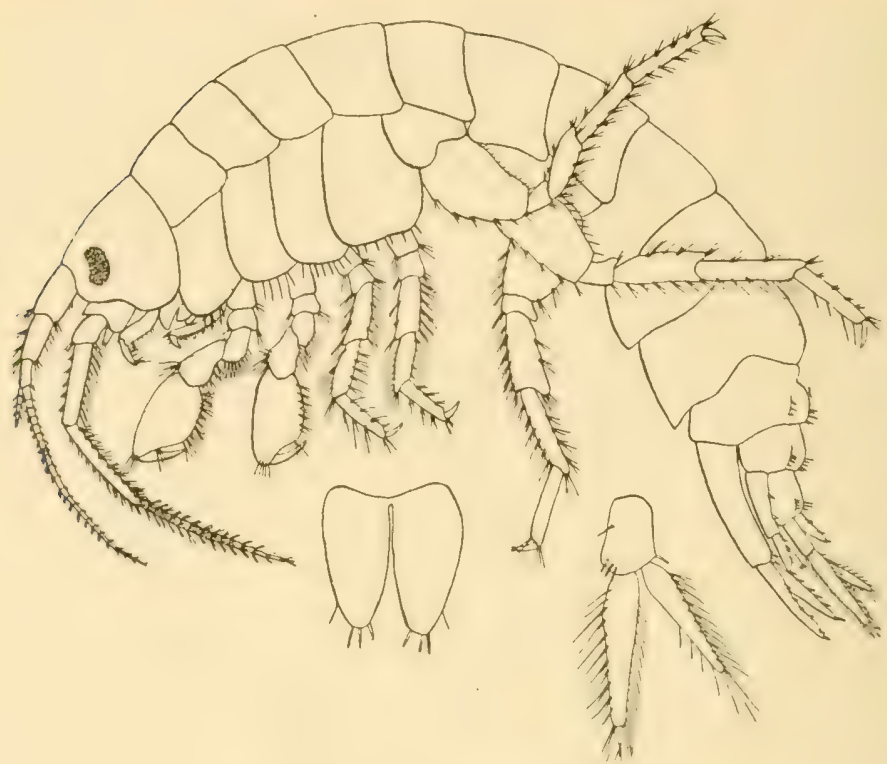

FIG. 25. Dikerogammarus fasciatus.

Iögy. Dikorogammarus fasciatus, Stebbing, Trans. Linn. Soc. London, ser. 2, vol. 7 , p. 428.

fourth and fifth segments of abdomen slightly raised to a twbercie dorsally and each armed with three fascicles of spines; sixth segment also with three fascicles.

First antenne with first and second joints of peduncle nearly equal in length and twice as long as the third; flagellum twice as long as peduncle; accessory fiagellum five- or six-jointed. Second antennac setose, about two-thirds the length of the first; last two joints of peduncle subequal.

First gnathopods in male with propodus much narrowed distally and with palm very oblique, with several small prehensile spines and a stout spine at middle. In the female, the propodus is less narrowed distally and palm is less oblique. Second gnathopods in male with carpus longer than in first gnathopods; propodus with margins nearly parallel, but widening slightly toward the palm which is a little oblique and concave and bears a stout spine near the middle. In the female the carpus is proportionally longer and as wide as the propodus which is narrow and rectangular. 
Terminal uropods extending well beyond the first and second; first pair extending beyond second pair; rami of first pair over half as long as peduncle and armed with spines; outer ramus of terminal uropods made up of two joints; inner ramus not quite as long as basal joint of the outer one which is very long. Telson cleft to the base, the lobes being furnished distally with two or three spines and a few cilia.

\section{Length IO-I $5 \mathrm{~mm}$.}

This species has a wide distribution in the eastern and central parts of the United States. It has been reported from Eastport, Maine; Hudson River and Niagara Falls, New York; Lake Superior; Burlington, Iowa ; Lake Geneva, Wisconsin ; IVashington, District of Columbia; St. Johns River, Florida; New Haven and Woodbridge (near New Haven), Connecticut.

It is abundant in fresh-water ponds among weeds and in brooks under stones.

\section{Gammarus Fabricius.}

Abdominal segments provided with fascicles of spines dorsally. First four pairs of coxal plates moderate, fourth pair the largest, distinctly emarginated in its upper part.

First antennæe generally longer than second, provided with well developed accessory flagellum. Second antennæ rather strongly built.

Mouth parts normal.

Gnathopods distinctly subchelate and more or less strongly developed being always much more powerful in male than in female. Pereiopods not greatly elongated.

Last pair of uropods projecting beyond the others, with rami spinous and setous, the outer one generally much the larger, and having a small terminal joint.

Telson rather small and cleft to the base.

\section{Gammarus locusta (Linnæus).}

I894. Gammarus locusta, G. O. Sars, Crust. Norway, vol. I, p. 499, pl. I and I76, fig. I.

1906. Gammarus locusta, Stebbing, Das Tierreich, Lief. 2I, p. 476 . 


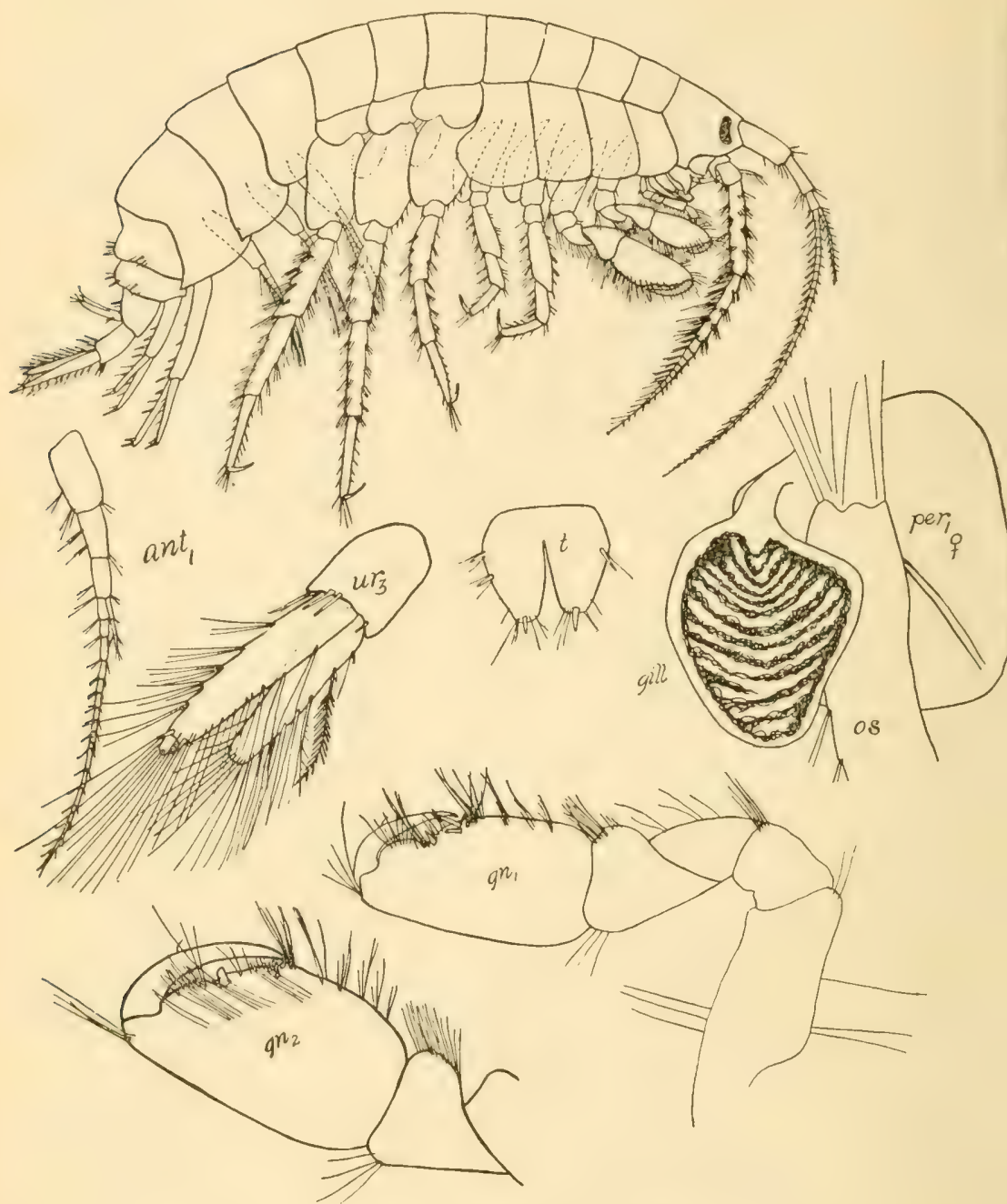

FIG. 26. Gammarus locusta.

Body slender and compressed. Eyes elongated; reniform.

First antennæ a little longer and more slender than second and in females generally less than half the length of the body; peduncle with first joint a little longer than the second, which is twice the length of the third; accessory flagellum about eightjointed and longer than second joint of peduncle. Second antennæ 
with stout peduncle which has the last two joints of subequal length; flagellum shorter than peduncle.

First gnathopods of male with propodus elongated, much longer than carpus, tapering from near the base and with palm, which is continuous with posterior margin, somewhat uneven and armed with a spine near the middle and a large spine with a row of several small ones at distal end. Second gnathopods of male with propodus much larger than in first, twice as long as carpus, subquadrate in form, slightly broader toward distal end, palm oblique and uneven and sharply marked off from posterior margin, armed with a stout spine near middle and several near prehensile angle. Gnathopods in female smaller than in male and more nearly of same size and shape.

Postero-lateral angles of second and third abdominal segments produced and acute, the margin above the angles generally furnished with short setæ; the three posterior segments with a median projection bearing a fascicle of spines and a lateral fascicle on each side.

Terminal uropods with both rami stout, inner one nearly as long as first joint of outer and armed with about four stout spines.

Telson with a group of two or three spines near base and three on apical margin, with another spine near the latter close to the outer margin.

Color olive brown to reddish brown; red, orange, or pink spots produced by globules may occur at the bases of the pleopods and first uropods as well as along the intestine.

Length about $25 \mathrm{~mm}$. According to Sars, Arctic specimens attain a length of $48 \mathrm{~mm}$. A few specimens collected at Savin Rock, near New Haven, measured $30 \mathrm{~mm}$.

Distribution: Arctic Ocean, Atlantic coast of Europe; Mediterranean; also in the Pacific Ocean it extends from Behring Strait for a considerable distance down the coasts of both North America and Asia. It is the commonest species along the New England coast. Within Connecticut it has been reported from New Haven, Noank, off Stonington, Fishers Island Sound, N. of Fishers Island ( $3 \frac{1}{2}$ to 5 fathoms), Long Island Sound.

In depth it ranges from low-water mark, where it is exceedingly abundant especially under stones, to a depth of over 50 fathoms. 
Gammarus annulatus Smith.

1873. Gammarus anmulatus, Smith, Rep. U. S. Fish. Com. for $187 \mathrm{I}-2$, p. 557 .

Eyes reniform, broader than in $G$. locusta.
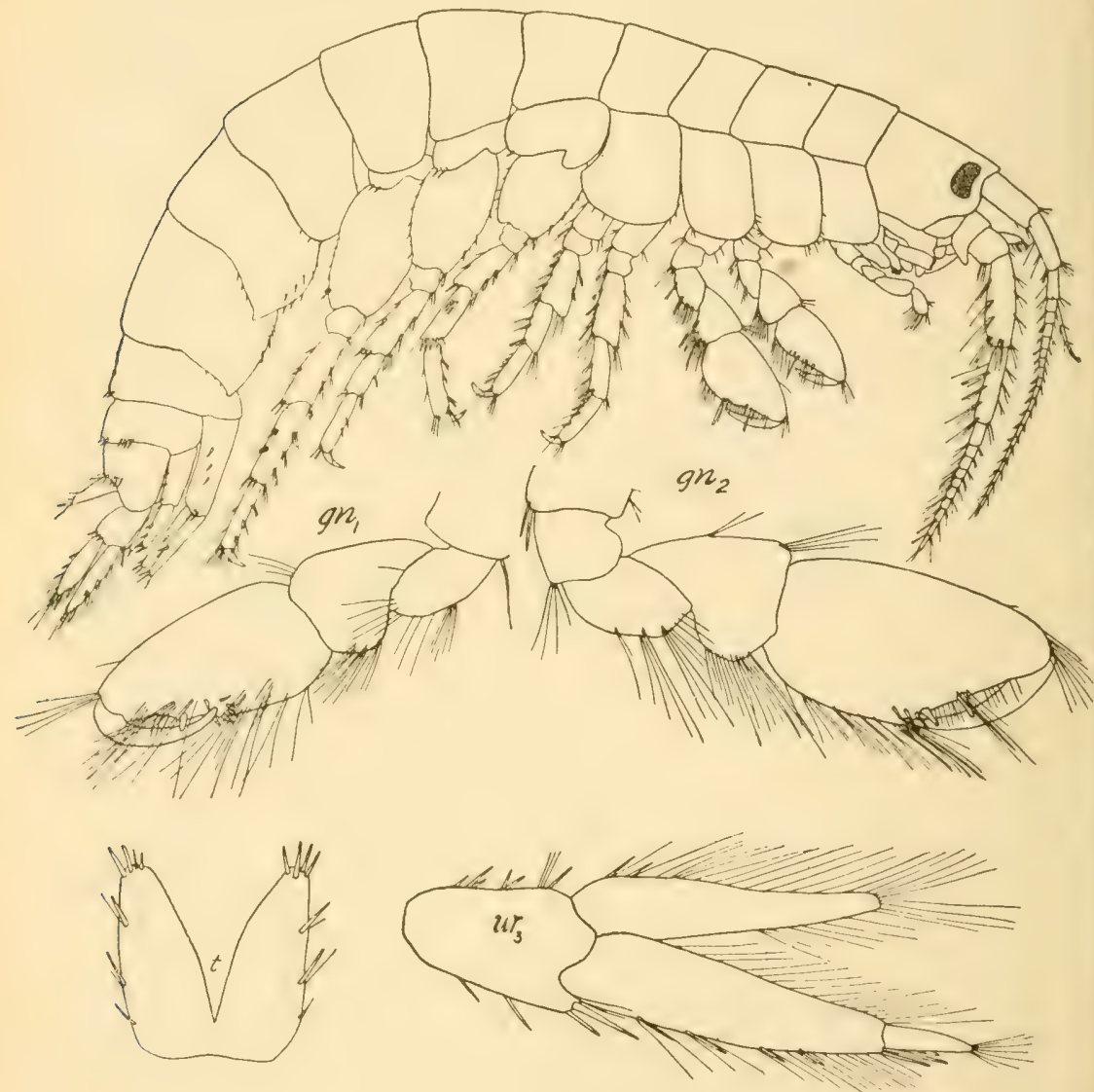

FIG. 27. Gammarus anmulatus.

Antenne less than one-third as long as body. First antennx shorter than second; first joint of perincle slightly ionger than second joint, third joint half as long as second; accessory flagellum longer than second joint of peduncle; principal flagellum slender, composed of about twenty joints. Second antennx with stout gland cone, and third joint as broad as long, fourth and fifth 
joints of peduncle subequal in length; flagellum stout, not as long as last two joints of peduncle together.

First four coxal plates deep with lower anterior margins provided with setre; first coxal plate not produced anteriorly.

First gnathopods smaller than second; carpus triangular, with posterior margin armed with long setæ; propodus oval, narrower distally, palm oblique and irregular and armed near middle with stout spine and at prehensile angle with numerous short spines; dactyl curved. Second gnathopods of same form as first but the propodus is slightly broader and has a less oblique palm which bears a stout spine at middle and several short spines at prehensile angle. Female with propodus of both gnathopods less stout than in the male and of nearly similar size and shape.

Pereiopods slender; first and second pairs with only a few spines but with numerous setæ which are especially abundant on the posterior margins of merus and carpus. Third, fourth, and fifth pairs with basal joints oval and armed with short setæ on front and hind margins.

Second and third abdominal segments with postero-lateral angles produced slightly to form an acute angle and with lower margins armed with short spines. Fourth, fifth, and sixth abdominal segments with median fascicle of spines on posterior dorsal margin; fifth and sixth segments also with lateral fascicles of spines.

Uropods biramus; last pair elongated and projecting well beyond others; rami narrowly lanceolate with margins abundantly provided with long plumose spines, outer ramus biarticulate, and armed on outer.margin also with a number of spines; inner ramus extending as far as first joint of outer ramus; peduncle armed distally with several long spines.

Telson with a variable number of spines on lateral margins and apically, cleft nearly to base and with lobes widely dehiscent.

Length $\mathrm{I} 5 \mathrm{~mm}$.

The species is found abundantly at times on the surface. According to Miss Rathbun, it occurs also under stones and in rock weed above low-water mark and from the surface to depths of I 3 fathoms.

It is found along the New England coast from Eastport, Maine to New Haven, Connecticut. Within the limits of Connecticut the species has also been taken off Fishers Island. 
Gammarus natator Smith is identical with this species.

(i. amulurus is likely to le confused with G. locusta but can le di-tingui-lued from the latter by the alsence of the lateral

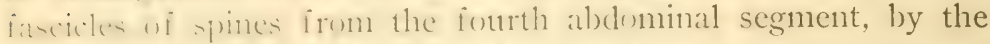
lon:- sta in plate of fascicles of spines on the rami of the last uropods, and by the different form of the gnathopods.

Gammarus marinus Leach.

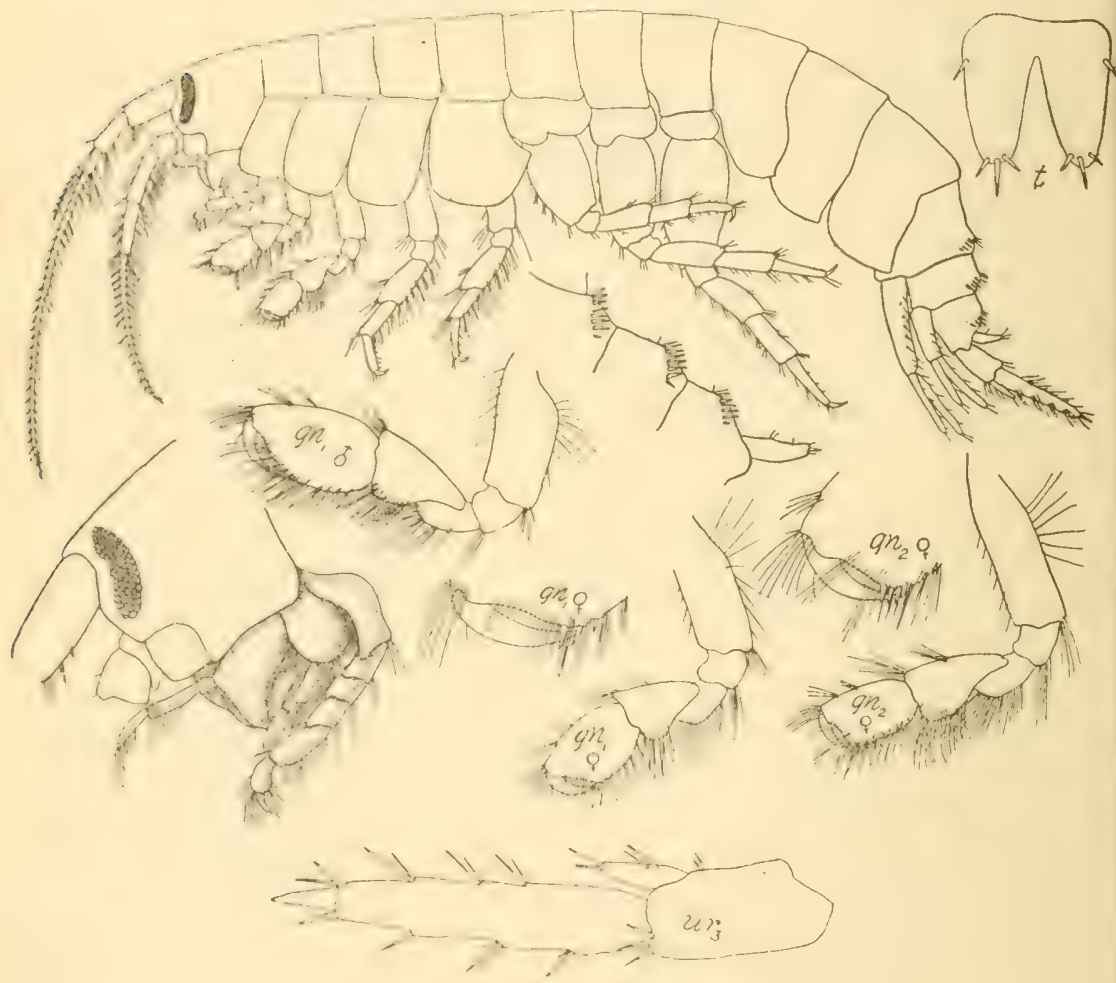

Fic. 28. Gammarus marinus.

ISI5. Gammanus marimus, Leach, Tr. Linn. Soc. London, vol, II, p. 359.

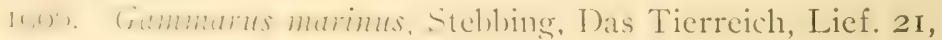
p. 472

linly anter and compressed. Interior pairs of coxal plates not nearly twice as deep as corresponding segments. 
Eyes very narrow, reniform; pigment very dark.

First antennæ nearly half the length of the body; first joint of peduncle as long as second and third combined; flagellum more than twice the length of peduncle, composed of about thirty-three segments; accessory flagellum not quite half as long as peduncle and composed of seven joints. Second antennæ considerably shorter than first, and having flagellum somewhat longer than peduncle.

Gnathopods not very strong, subequal in both sexes, those of female having propodus oval quadrangular in form with palm more oblique in first than in second pair; those in male a little stronger, with propodus more oblong in form. Three posterior pairs of pereiopods comparatively short and stout with outer joints armed with fascicles of small spines.

Fourth, fifth, and sixth segments of abdomen with three fascicles of strong spines which are arranged in two rows converging above, each row arranged in two groups slightly apart.

Last pair of uropods with outer ramus well developed and coarsely spinous on both edges; inner ramus extremely small, scarcely one-third as long as onter one, and narrow conical in form. Telson comparatively small, each lateral half with one lateral and three apical spines.

\section{Length I $_{5} \mathrm{~mm}$.}

Distribution: British Isles; coast of France; Mediterranean; Vineyard Sound, Buzzards Bay; Woods Hole, Massachusetts; Newport, Rhode Island; New Haven, Noank Harbor, Connecticut.

The species is found under stones below high-water mark and is sometimes abundant.

\section{Carinogammarus mucronatus (Say).}

I8I8. Gammanis mucronatus, Say, Jour. Acad. Nat. Sci. Phil., vol I, pt. 2, p. 376 .

1905. Carinogammarus mucronatus, Holmes, Bull. Bur. Fish.; vol. 24, p. 503.

Eyes reniform.

First antennæ a little longer than second ; first joint of peduncle longer than second, third joint three-fifths as long as preceding; flagellum twice as long as peduncle; accessory flagellum composed of three or four joints and not half as long as peduncle. 
Sermel antemie with flagcllum epual to last two joints of peduncle, of about ten segments.

first intur coxal plates deep ; first three oblong; fourth wide.

lin-t mathoruels in male stont, smaller than second; carpus le..- than halt as homg as propolus which is narrowly oval, palm monell, very oblique and continuons with posterior margin; lunudus wi scomd patir ol)long, with the two sides nearly parallel and the palm oblique and concave near the middle.

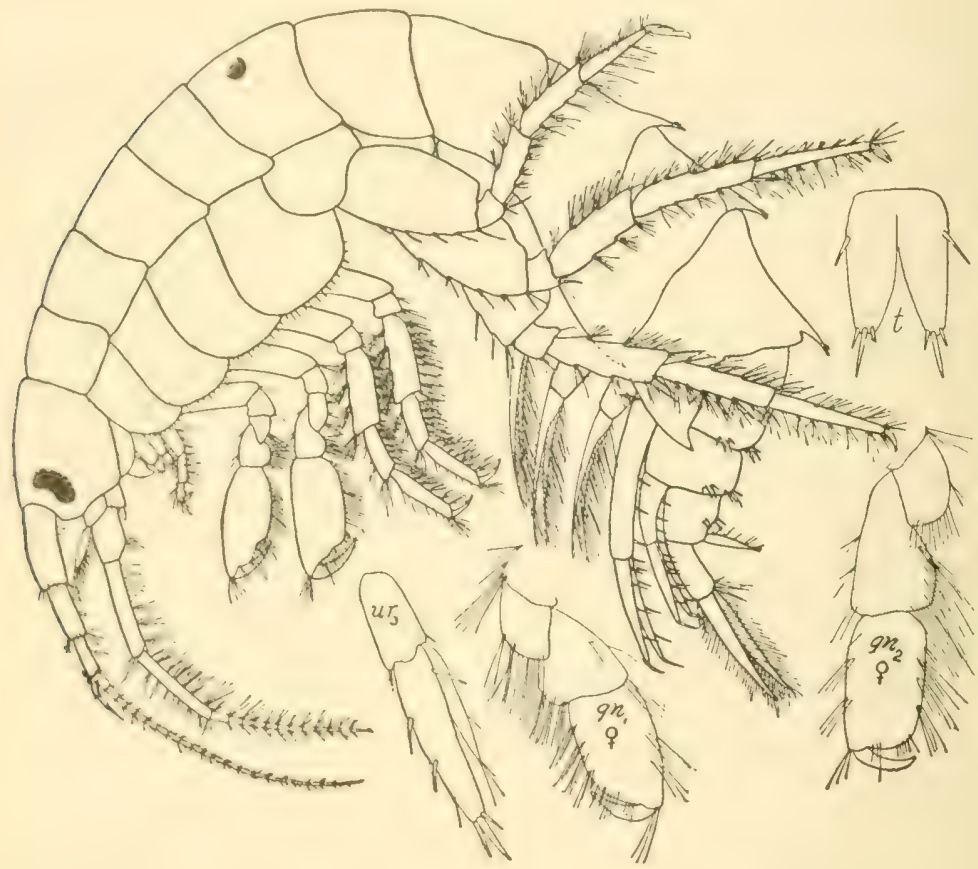

FIG. 29. Carinogammarus mucronatus.

I'usterior margins of first three abdominal segments produced hackwarl in the mid-clorsal line into a prominent acute tooth; last three segments with fascicles of spines.

Thirl uropods with flattened rami much longer than peduncle; (nuter one biarticulate and larger than inner one and provided on margins and anex with setie and spines. Telson cleft nearly to bate and proviled with three terminal and a few lateral spines on each lobe. 
Color, olive green with red spots on first four abdominal segments as in Gammarus locusta.

Length $6 \mathrm{~mm}$. A few specimens from New Haven measured I4 $\mathrm{mm}$.

Distribution: Cape Cod to Florida. Within Connecticut it has been reported from Noank, at the surface and in eel-grass, and from New Haven.

The species occurs often in brackish water and is common among alga. Two specimens in Peabody Museum were obtained from the branchial cavity of Mya. Smith records this species from the stomach of the tomcod and spotted flounder.

\section{DEXAMINID瓜.}

Fifth and sixth segments of abdomen fused.

First antennæ with second joint of peduncle long; without accessory flagellum.

Mandibles without palp. First maxillæ with inner plate having only one or two setæ. Second maxillæ with inner plate the smaller, and not fringed on inner margin. Maxillipeds with outer plates very long and palp rather short with fourth joint either small or wanting.

First and second gnathopods feeble, subchelate. Pereiopods with dactyls all commonly pointing backwards.

Third uropods with rami subequal and extending beyond second pair. Telson elongate, deeply cleft.

\section{Dexamine Leach.}

Body comparatively stout with some of the segments elevated to strong, dorsal projections. Last two segments of abdomen completely fused. Coxal plates increasing in height to fourth pair; fifth pair much larger than succeeding pairs.

Antennæe very slender; first pair with peduncle much elongated and without accessory flagellum; much longer in the female than the second which, however, in the male is greatly prolonged.

Mandibles without palps. First maxillæ with inner plate very small and bearing a single seta apically; palp uniarticulate though rather large. Maxillipeds with outer plates very large, nearly concealing the comparatively small and slender palps. 
Cinathoupde not very strong and somewhat unequal, the second pair leing more elongated than the first; propodus in both pairs consideribly dilated in middle and distinctly subchelate.

Last pair of uropors of moderate size with rami subequal and narrow lanceolate in form. Telson much elongated and deeply cleft with lateral edges spinous.

Dexamine thea Boeck.

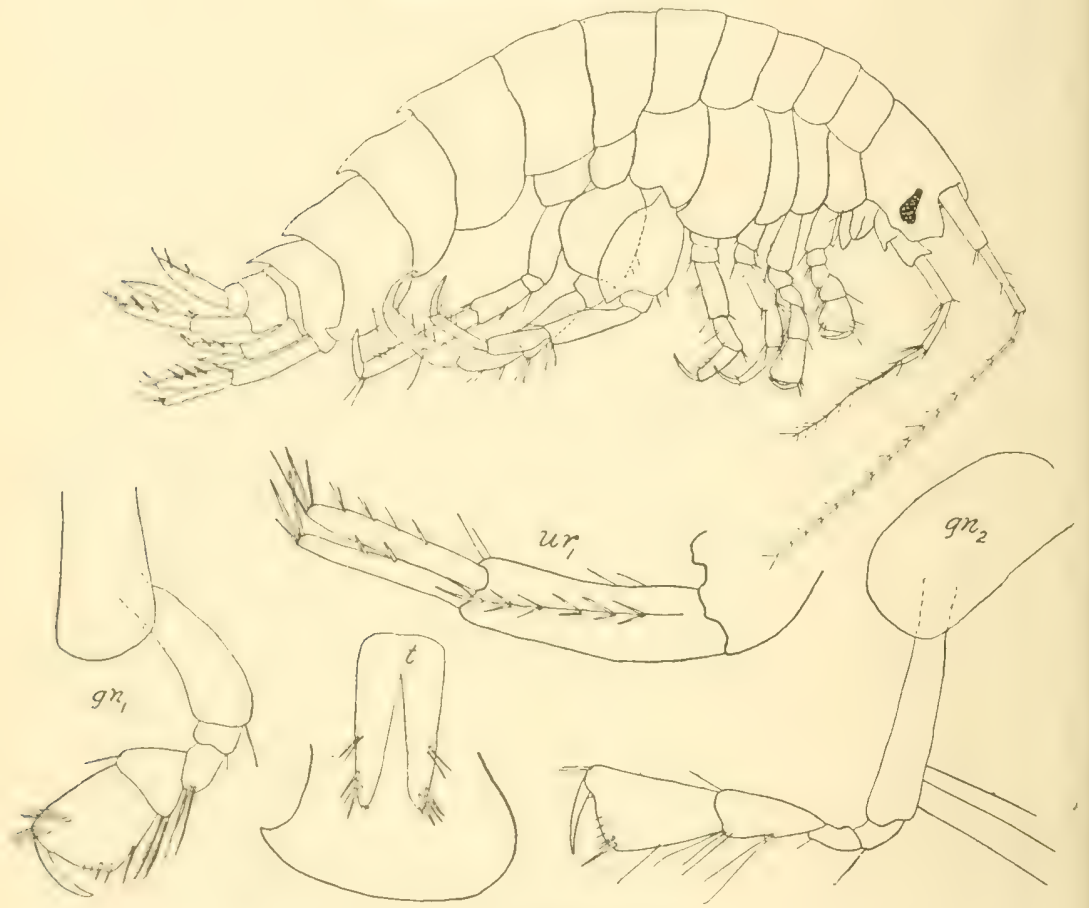

FIG. 30. Dexamine thea.

1893. Deramine thea, G. O. Sars, Crust. Norway, vol. I, p. 477 , pl. 168, fig. I.

Heat produced into a small rostrum; interantennal lobes litre and pointed. Lyes large, compound, oval to pyriform in shape.

First antemne over half as long as body; first joint of peduncle stout and nearly as long as second joint, which is slender, and three times as long as third; flagellum slender, made up of 
twelve to sixteen segments. Second antennæ much shorter than first; last two joints of peduncle subequal in length; flagellum not exceeding the peduncle in length, composed of five to nine segments.

First four coxal plates well developed and much deeper than their segments with lower margins setose.

First gnathopods stouter but shorter than second; carpus short, subtriangular; propodus broader than carpus, with oblique, finely pectinated palm which is as long as hind margin and separated from it by two large spines. Second gnathopods with carpus narrowly triangular, with a fascicle of setæ at lower posterior angle; propodus widening regularly toward distal end, palm oblique, finely pectinated, rounded posterior angle armed with two stout spines; propodus and carpus taken together forming an elongated triangle. Pereiopods very spiny; dactyl narrow over half as long as propodus; basal joint of third pair of pereiopods cxpanded and prolonged slightly distally behind; basal joint of last pair not expanded.

First four abdominal segments armed dorsally with a strong posterior spine. Postero-lateral angle of third segment produced and acute.

Second pair of uropods much shorter than first or third; rami provided with a long terminal spine and several shorter lateral ones; terminal uropods extending a little beyond first pair; rami subequal, flattened, much longer than peduncle.

Telson much elongated, extending nearly to tip of posterior uropods, cleft nearly to base; lobes denticulated at apex and furnished with several tufts of spines near lateral margins and one or more at distal end.

\section{Length $3 \mathrm{~mm}$.}

Distribution: Norway; British Isles; France; Woods Hole, Massachusetts; Noank Harbor (taken at the surface in the evening, July I3, I874), off Stonington, Connecticut; Long Island Sound.

\section{ORCHESTIIDE.}

Mouth parts strongly projecting downwards.

First antennæ usually much shorter than second pair; without accessory flagellum. Second antennæ with first joint of peduncle coalesced with the head. 
Mandibles withent palp. First maxille with inner plate slmeler and tipjed aprically with two plumose setæ; palp uniarticulate, small.

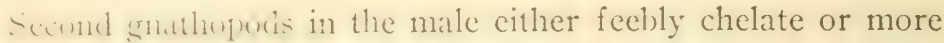
u-ailly strumly suluhclate; in the female either feebly chelate or subchelate.

Thirel uropuls ustally with a single ramus. Telson usually short.

\section{Orchestia Leach.}

First pair of coxal plates small; fifth pair almost as deep as the preceding and deeply bilobed.

lirit antenne very small, much shorter than peduncle of scernd which is clongated and sulperliform and has the first two joints coaleseed with the head and not provided with a gland cone.

Mandibles without palp. First maxillae with only a slight rudiment of a palp). Maxillipeds with the triarticulate palp short and broad.

Firs gnathopds small, subchelate in both sexes, the propulus with a distinctly defined palm. Second gnathopods very disimilar in the two sexes; in female feeble, with an imperfectly chelate propodis and rudimentary dactyl; in male very strongly developed, with subchelate propodus.

Timinal urupols with a single minute ramus. Telson short, thick, and broad, rounded at the tip.

\section{Orchestia agilis Smith.}

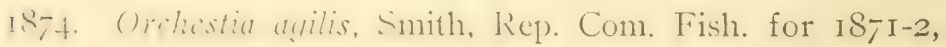
p. 555, pl. 4 , fig. I4.

Eyes large.

lörs antenna very short, not reaching as far as penultimate juint wi pertum te of second pair; thagellum shorter than peduncle and male mp wi three or four secments. Second antenne less than late as long as borly: peduncle stonter in male than in female with last joint sliwhty longer than preceding; flagellum shriter than perlumcle and male up of ten or fifteen short segments.

lirst pair of coxal plates higher than long and considerably smaller than second pair. 


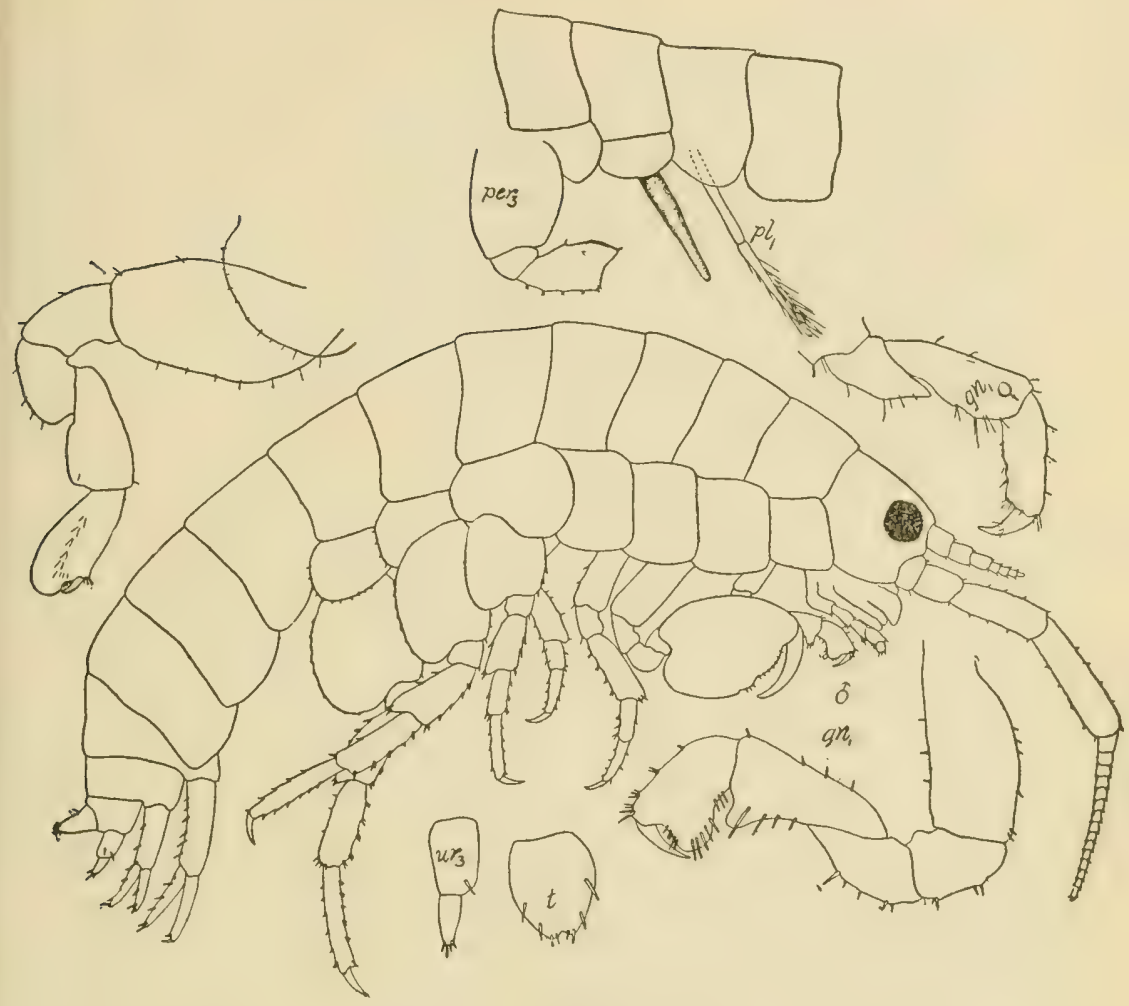

FIG. 3I. Orchestia agilis.

First gnathopods of male subchelate, with carpus longer than propodus and provided with a prominent rounded lobe at distal end of posterior margin; propodus widened distally, with inferoposterior angle produced into large rounded lobe against which the dactyl closes, distal end of propodus rather deeply notched. Second gnathopods with large oval propodus and small carpus; palm of propodus oblique and convex, slightly notched near posterior end; dactyl long and curved. In female, first gnathopods simple, with propodus shorter than carpus and tapering slightly distally. Second pair with carpus rounded on posterior margin; propodus shorter than carpus, oval, with a minute dactyl articulated on anterior margin and not reaching distal end of segment. 
liith pair of pereiopods of adult males with merus and carpus greatly swollen.

Kinni oi lirst mopods considerably shorter than peduncle; semml pair with rami subepual to peduncle; third pair with ramus muile mute slemeler than peduncle and nearly as long. Telson narrowly rounded behind.

The color of this species is very variable from olive brown and liak green to whitish. The legs, coxal plates, and posterior purtins of the ludy are bluish, and the antennze are reddish or recldish brown.

\section{Length io $\mathrm{mm}$.}

Distribution: Itantic coast of North America from the Bay oi Funcly to New Iersey; Bermuda; the Mediterranean; New Haven, Connecticut; Long Island Sound.

This species is excerdingly abtundant under seaweed near highwalcr mark lut not so hich on the beach as Talorchestia longiimmis. It is thstally at least a few inches beneath the surface wirre the weels are damp), and when masses of seaweed are upturned, the ati farly swarms with these animals, which hop about with weat rapidity and to relatively great distances. It is by far the most active of the sand fleas. It also burrows in the sand and is arasionally found on piles at some distance from shore. It feels matinly on decaying seaveed but also partakes of animal food.

Vlthomph the species is generally found on shore, it is able (1) swim atively. It is strongly attracted by a light and large numbers may le oluained by placing a lantern on the beach along sicle of a rescel of sea water or alcohol and simply stirring 11) the seawerel within a radits of several yards. The animals hop towarls the limht and when they fall into the water they are mathle to erawl up the smonth sides of a bucket or glass dish.

Holmes gives a full account in the American Journal of

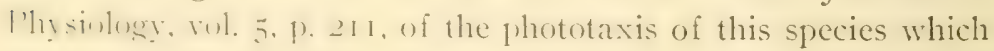
may be negative under certain conditions.

\section{Orchestia palustris Smith.}

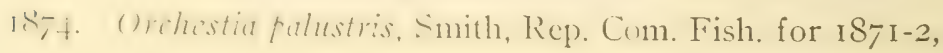
P. 55.5 .

lint antemate reaching slightly heyond pentimate joint of firlunte ut acomd antenna: flagellum as long as peduncle. 
Second pair with slender peduncle not as long as flagellum, fourth joint two-thirds as long as fifth.

First pair of coxal plates quadrate and as long as high.

First gnathopods of male as in preceding species. Second pair with large oval propodus, having palm very oblique, evenly convex and spinous, and with a slight process at posterior end against which the tip of the dactyl fits. In female, first gnathopods similar to those of $O$. agilis; second pair with basal joint somewhat broader and more rounded in front but otherwise very much like the preceding species. Pereiopods four and five with carpus slender even in the largest males.

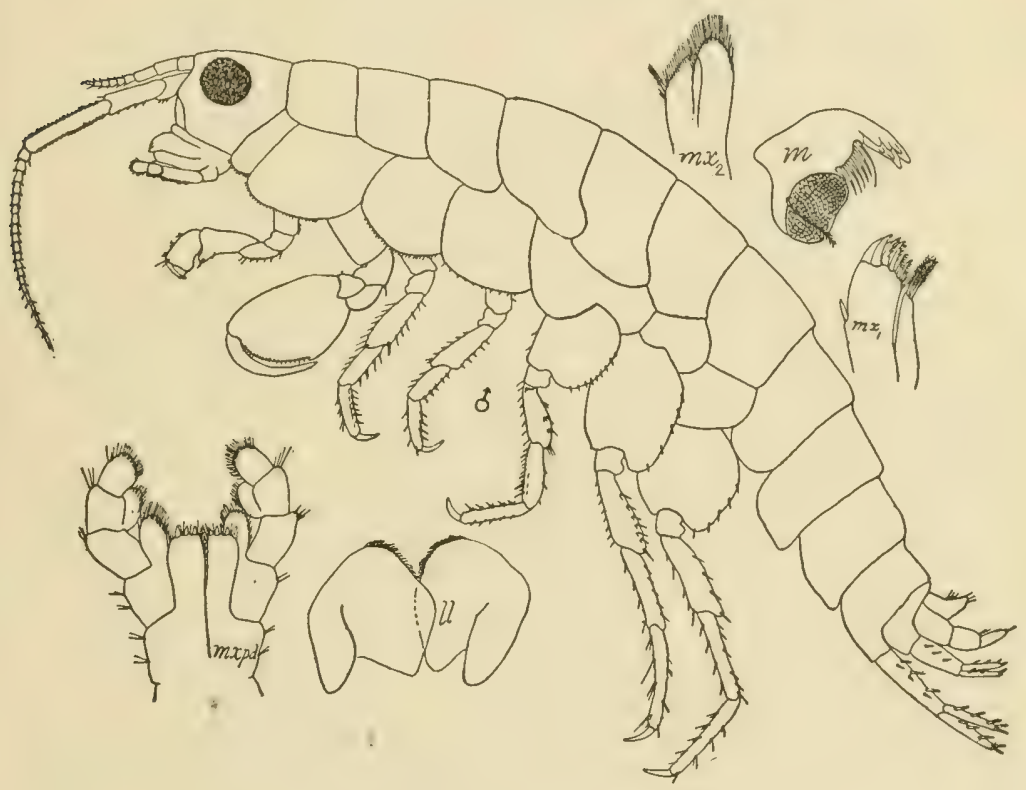

FIG. 32. Orchestia palustris.

Postero-lateral angles of second and third abdominal segments produced into acute points.

First uropods with rami shorter than peduncle; second pair with rami equal to peduncle; terminal pair with a single ramus which is longer than the peduncle and relatively larger than in $O$. agilis. Telson bearing a posterior notch, lobes rounded and spinous. 
(i)lor, olise hrown to olive green, occasionally reddish-brown; antenna, reddish-brown.

Length of female $18 \mathrm{~mm}$., of male $22 \mathrm{~mm}$.

This succies is readily distinguished from the preceding by its larser size, longer first antenne, and more slender second antenne, and by the larger size of first coxal plates.

1)i-trilution: (ape Cod to New Jersey; coast of Texas; New Haven, Connecticut.

The habitat of this species is different from the preceding, heing nusully in the neighborhood of salt marshes and often quite far from the shore in almost dry places among grass and weeds. This species crawls more readily than agilis but is a weaker hopper.

For a fuller account of its habits the reader is referred to Miss cmallwoul's contribution in the Cold Spring Harbor Monograplis, No. 3, igo5.

\section{Talorchestia Dana.}

Cimilar to ()ristiu except that first gnathopods in female are simple insteal of suldelelate and second pereiopods usually hate inner margin of diatyl more sharply constricted than in allied genera.

\section{Talorchestia longicornis (Say).}

sis. Tilitrus lonulicomis, Say, Jour. Acad. Nat. Sci. Phila., aol. I, pt. 2, p. 384 .

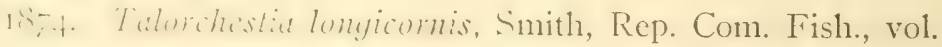
I, p. 556 .

Eyes large and circular.

firret anteince short, extending slightly beyond penultimate junt wi secont pair which is one-third as long as body in female, lut which nay crual the length of the body in the male; flagellum multiarticulate and longer than peduncle.

Jouth parts forming a conspicunus projection on ventral side of head, extending betow the level of the coxal plates. Mandibles without palp. Maxillipeds with triarticulate palp.

Coxal filtes increasing in levight and length from the first to the fourth, lut not so high as their respective segments, their ventrat marcins slighty rommled and provided with numerous short 
setr; fifth, sixth, and seventh plates decreasing in size posteriorly. First three abdominal segments with postero-lateral corners rectangular or slightly acute.

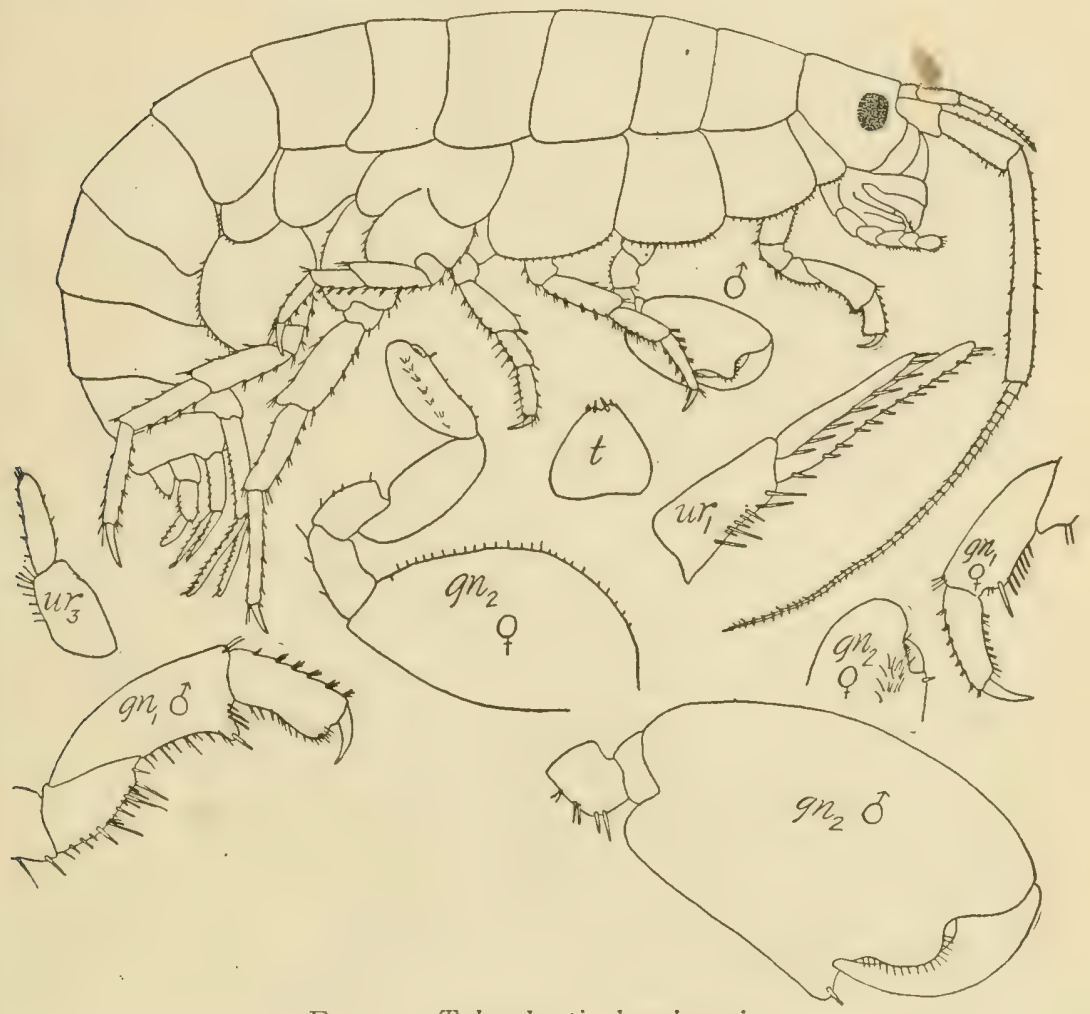

FIG. 33. Talorchestia longicornis.

First gnathopods in male with carpus produced at posterodistal angle to form a long, rounded lobe; propodus shorter than carpus, widening somewhat distally and with postero-distal angle slightly rounded and produced and covered with dense spines, palm transverse and short. Second gnathopods of male with propodus large and oval with anterior margin rounded and posterior one nearly straight, palm oblique, defined by a blunt tooth, between which and the hinge is a convex lobe provided with setr. In female the first gnathopods resemble those of male but the carpus lacks the rounded process and the propodus tapers distally so that there is no distinct palm. Second gnathopods weak, basal 
joint very broal, with anterior margin strongly convex and provided with short setie; propolus oblong, with anterior margin slighly concave and shorter than posterior one, distal end rounded: rery weakly chelate; dactyl rudimentary. Second perei(1puels sherter than first; third pair very short and with basal joint ncarly circular: fourth and fifth pairs short and stout.

first urnguds extending slightly beyond second, with rami sulerutul in length to each other and to peduncle; second pair with rami longer than peeluncle and with inner ramus considerably longer than onter: teminal uropods with single ramus as long as peluncle lut much narrower. Telson triangular, fleshy, emarginate.

Color grayish or sand-colored. Antennæe pinkish or red at base, flagellum blue.

Length $20 \mathrm{~mm}$.

Distribution: Cape Cod to New Jersey; New Haven, Connecticut.

This species is usually quite abundant on sandy beaches at or almo high-water mark where the animals burrow beneath the suriace in order to reach moist sand. The species is nocturnal in its hahits and in the daytime the individuals remain quiet in their hurrows and their presence is indicated only by small holes in the sund. In the night they run about over the seaweed that has recently lewn washed ashore and which furnishes their principal foud. The species is strongly attracted by a light and may he wathered in large numbers simply by placing a lighted lantern in the midlle of a sheet spread on the beach where they are known to be. When dug out of the sand in the day, Talorchestia is rather slugri-h and may feign death, but when aroused it makes a few leaps and if it alights on loose sand it remains quiet a moment and then very quickly begins to burrow.

Tulurchstit is calpable of swimming rapidly when driven out of its burrows by a particularly high tide.

Mis Smallwool in Culd siring I Larlor Monographs No. I, Ig0.3. has described the hallits and variations of the species quite fully.

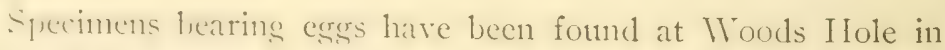
July and August. 
Talorchestia megalophthalma (Bate).

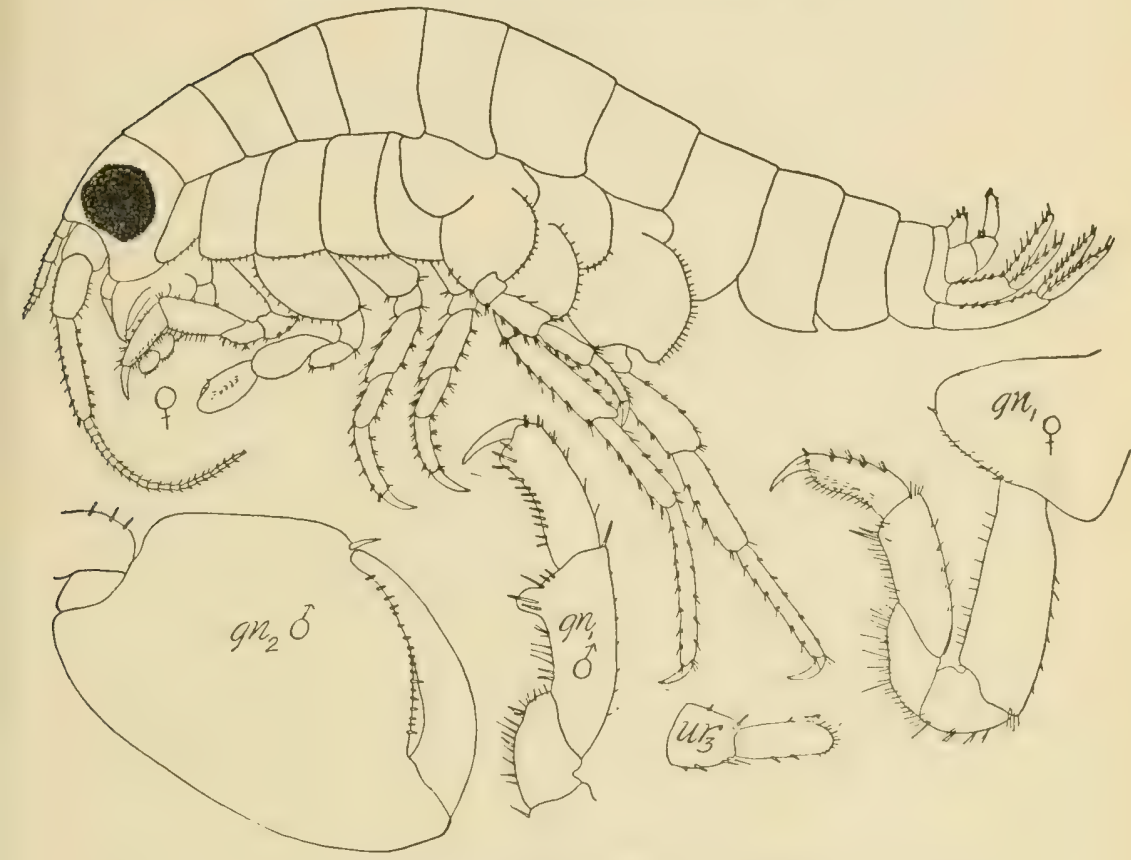

FIG. 34. Talorchestia megalophthalma.

I862. Orchestia megalophthalma, Bate, Catalogue Amphipoda Brit. Mus., p. 22, pl. 3, fig. 8.

I874. Talorchestia megalophthalma, Smith, Rep. Com. Fish., vol. I, P. $55^{6}$.

Eyes very large, covering almost entire side of head.

First antennae short, with flagellum shorter than peduncle, extending as far as penultimate joint of peduncle of second antennæ, which are shorter than those of $T$. longicomis.

First gnathopods of male with propodus tapering slightly to distal end where posterior margin bears a rounded lobe, no distinct palm; carpus with prominent lobe near distal end of posterior margin. Second gnathopods of male with large ovate propodus having palm evenly convex and with prominent lobe posteriorly bearing a strong spine. Gnathopods of female very similar to those of $T$. longicornis. 
Scomel aldeminal segment with prostero-lateral angle produced into a small acute triangular process.

First urepeds with rami equal and about as long as peduncle; scomel pair wih rami longer than peduncle and with inner ramus lonere than cuter: terminal pair with ramus slightly longer than peduncle.

\section{Length I $5 \mathrm{~mm}$.}

Miss Smallwud, in (uld Spring Harbor Monographs, No. I, regatris this species and the preceding as different stages of the same form, meyulophthulmu being a younger stage of longicornis. Aside from the difference in the length of the antenna, however, upun which Aliss smallwood hases her conclusions very largely, the two species difier from each other in the size of the eyes, the difierent form of the second gnathopod of the males, the lonerer monus of the third uropod of megalophthalma, and by the triansular pricess on the postero-lateral angle of the second abdominal segment.

Distrilution: This species has the same range as the preceding and wours in sinilar situations hut is far less common than longicomus. Noank and New Haven, Connecticut.

\section{Hyale H. Rathke.}

Fourth coxal plates much deeper than fifth. First antenne longer than peduncle of second.

First maxilla with uniarticulate palp reaching to base of apical spines of outer plate. Maxillipeds with four-jointed palp.

second gnathopods in male with carpus small and masked behimel hy the merus; in female carpus produced behind, between adjacent segments.

Third uropods uniramous. Telson unarmed, divided to base.

Hyale prevostii (Milne-Edwards).

IS.30. Amplithoe próntii, Milne-Edwards, Ann. d. Sci. Nat. vol. 20, p. 378 .

IS88. II yle prowstii, Stchbing, Rep. Voy. "Challenger," vol. 29 , p. I 44 .

Back smooth, coxal plates with lower margins smooth; first pair widened below.

Eyes small, round. 
No. 26.] ARTHRostraca OF CONNECTICUT.

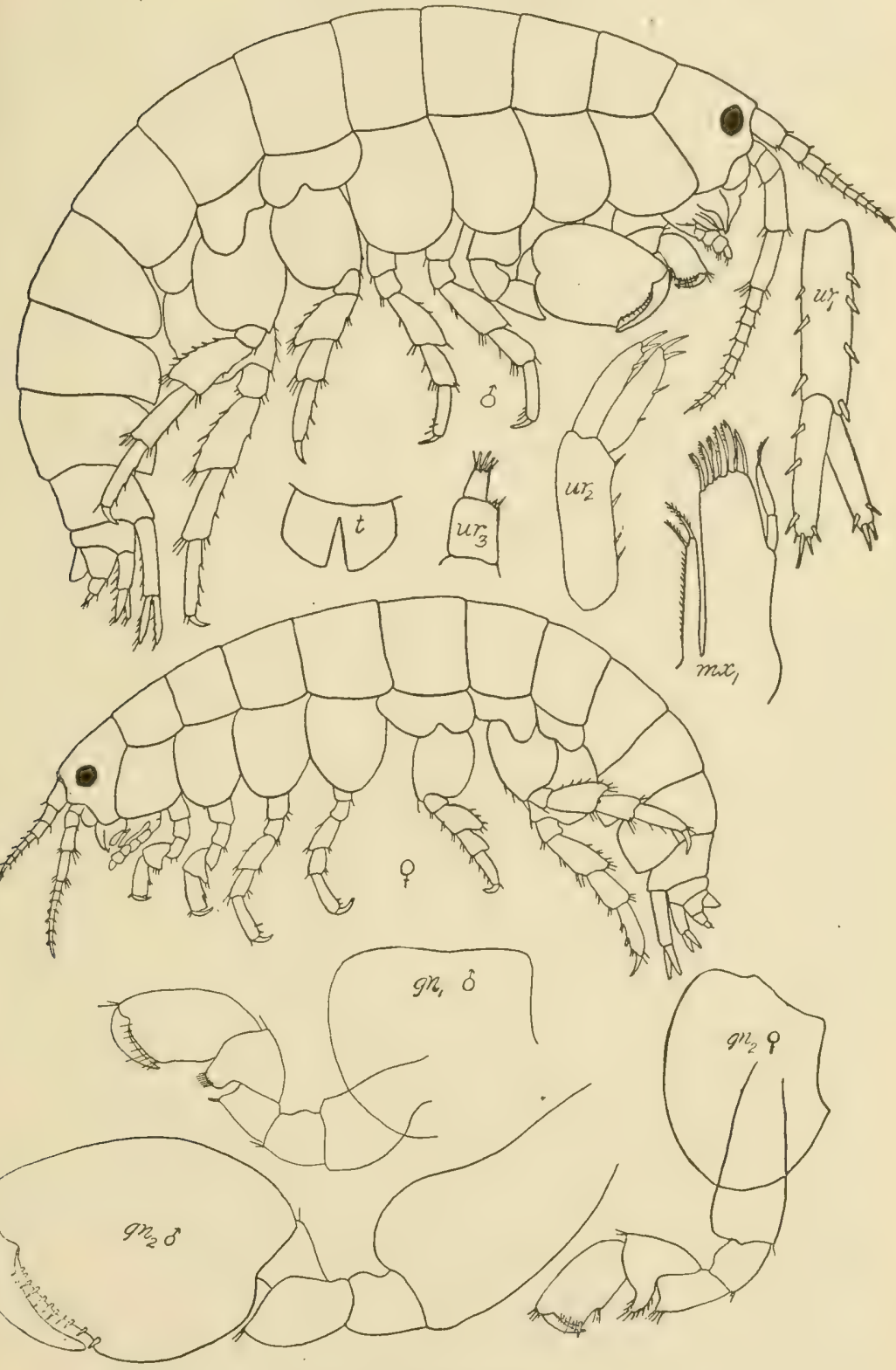

Fig. 35. Hyale prevostii. 
lirst antennit as long as head and first segment of thorax tuecther, extciding well heyond the peduncle of second antenna; prifuncle with joints becombing successively smaller; flagellum longer thatn peduncle and made up of about ten joints. Second antentic with list joint of peduncle the longest; flagellum longer than peduncle and made up of about a dozen segments.

First gnathopols in the male with short, stout basal joint, rarcily twice as long as wicle; carpus triangular, with short, pusterior margin strongly convex and armed with many setæ; propulus subrectangular with front margin strongly convex, about twice at long as wide, palm slightly oblique and convex; dactyl stut and curved. Siecond gnathopods very large; basal joint sout and expanded below in front; merus bearing a triangular process distally; carpus very small and inconspicuous; fropulus larese and oval, palm oblique and convex, armed with a row wi shor -prine teeth, prehensile angle prominent but rounded.

In the iemale the two pairs of gnathopods are of the same form, Int the sccond pair is slightly larger than the first and the (ampus of the first is relatively longer than that of the second; propurlus subrectangular with fascicle of spines at middle of persterior margin, dactyl longer than palne. Pereiopods stout, and provided with numerous spines and sete. Third to fifth pereiopuds with hasil joint expanded and hind margin smooth. Fourth and fith pairs with propodus armed with a spine at the middle of the hind margin.

I'ostero-lateral angle of third abdominal segment very slightly produced, forming less than a right angle.

Fir-t uroporls extending beyond the others; rami short and spinents on marsins and apex. Terminal pair small, with ramus much shorter than peduncle.

Telson divided into two obtuse lobes.

Length 6-8 $\mathrm{mm}$.

l)intribution: Atlantic coast of Europe; Azores; Bermuda; Viank, Comnecticut, low water, Lug. 29, I874, and Long Island Sound.

\section{Hyalella Smith.}

Similar to Il yale except that first maxillo have a smaller palp mot reaching the base of apical spines of outer plate. Second 
Wes nearly round, their distance apart slightly greater than their cilameter.

liris antmine shorter than second pair; first and second semmons wi ferluncle subequal in length and slightly longer than 1hind: Hiagellum about twice as long as peduncle and made up of cevent to nime joints. Second antemne half as long as the body; perfumele exceding that of the first pair; last two joints elongated and stulupual: Hatgellum usually only slightly longer than that of first pair.

loirt anathepuls in the male with carpus longer than propulus and having a rounded lobe posteriorly densely setose; propultus more than hali at long as wide, subrectangular, provided with a sroup) of short cilia near the distal end of front margin and a fiscicle of long ones at the apex; palm nearly transverse, lighty sinumus and provided with a prehensile spine; dactyl strongly curved and shorter than palm. Second gnathofunls in the male with enormuts oval propodus; carpus short, with a lons, slender lobe extending along the posterior margin of propulus which is more than half as broad as long, palm oblifue. the midlle portion slightly arcuate and provided with a notch near the midtle, armed with a submarginal row of spines, prohensile angle prominent, rounded. Second gnathopods of the female clongated, weak; carpus wider than propodus with small, rounded lobe behind, provided with a group of setæ; propolus somewhat curved and broadest distally, more than twice as lone a broat, posterior margin prolonged to form a chela with the dacty. which is shorter than the palm and not strongly curved. l'usterior margin of basal joints of last three pereiopods serrate.

Postero lateral angles of third abiominal segment produced slightly to form a triangular tooth: first two or three segments usually produced dorsilly to form a well marked posterior tooth on the middle line.

First uropods almost twice as long as the second pair. Termimal pair very short, not exceding the peduncle of the second foir in leneth; perluncle very short, nearly as broad as long, furnisher distally with a few seta: ramus tapering, as long as perluncle, with a few setar at afex. Telson short, entire, nearly a I rad a lime and furnisherl with a slemer seta on each side. 


\section{Length $7 \mathrm{~mm}$.}

Very abundant in streams, lakes, and stagnant pools throughout the entire United States. New Haven and Canaan, Connecticut.

\section{Allorchestes Dana.}

First antennæe longer than peduncle of second.

First maxillæ with uniarticulate palp. Maxillipeds with fourjointed palp.

Second gnathopods in male with carpus produced behind between the adjacent segments.

Telson more or less divided.

Allorchestes littoralis Stimpson.

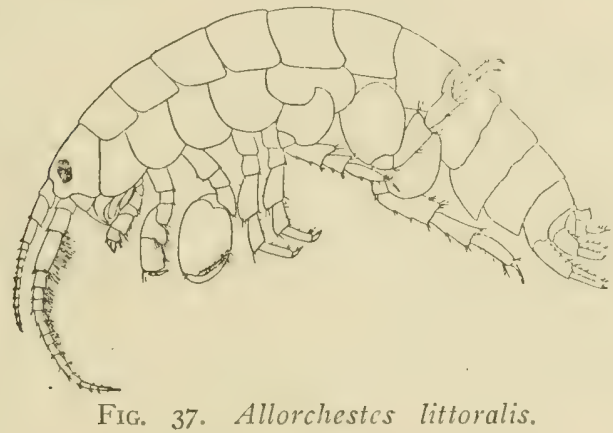

1853. Allorchestes littoralis, Stimpson, Marine Invert. Grand Manan, Smithson, Contrib. Knowl., vol. 6, No. 5, p. 49, pl. 3, fig. 36 .

1874. Hyale littoralis, Smith, Rep. Com. Fish., vol. 1, p. 556.

Eyes oval, moderately large, situated rather close together.

First antennx three-fourths the length of second with the three joints of peduncle of subequal length; flagellum longer than peduncle and made up of nine to thirteen joints. Second antennæ less than half the length of body, last joint of peduncle slightly longer than preceding one, the lower side furnished with a large tuft of plumose spines.

First gnathopods much alike in the two sexes; merus produced distally into a prominent setose angle; carpus with posterior lobe oblong, rounded, and thickly setose; propodus oblong, widen- 
ing distally, palm slightly convex and nearly transverse, prehensile ancle armed with two short, stout spines, posterior margin with I scture convexity just distal to the middle, dactyl closely fitting lalm, with a single slort seta on outer margin near base.

Cund gnathopods stont in male; basal joint elongated and (n) mave anteriorly; merus twice as long as ischium and strongly fruduced distally into a pointed lobe; carpus with posterior lobe rey long and narrow; propodus large, oval, palm oblique and (venly consex with two short, stout spines at prehensile angle, josterior margin with a mall setose convexity near the palm; ditctyl much ats in lirst gnathopods. In female the posterior lobe oi cirjus not nearly so narrow and propodus smaller and more oblons than in male; palm more oblique than in first gnathopods.

First and second uropods with rami subequal to peduncle; lirst pair with peduncle armed above with two rows of three or funt spines eatch, last spine of inner row enormously developed burt two-thirds the length of rami; each ramus with two spines (nn miner margin and a cluster at the tip. Peduncle of last uropouls very short and stout, with a single stout spine on upper marein; ramus as long as peduncle but much narrower, furnished with a cluster of spines distally.

Telson deeply bilobed.

fincral color, green to olive-brown; antennae reddish brown; eyes black.

Length 6 mm.

1) istribution: Grand Manan to Long Island Sound; New Haven, Connecticut (Smith).

This species occurs on rocky shores high up on the beach mear himh water: on piles, and in tide-pools. It approaches a terrevinil hahit like Orchestia, ats it can walk upright with some difficulty while out of water and hops quite readily.

\section{AORIDAE.}

Fourth coxal plate not excavate behind.

first antemic lunger than second; third joint of peduncle short; accessory flagellum present.

first matille with a single seta on inner plate; second joint of palp elongate. 
First gnathopods larger than second and showing considerable differences usually in the two sexes. First and second pereiopods glandular. Last pair of pereiopods the longest.

Terminal uropods biramous, not elongate. Telson simple.

\section{Microdeutopus Costa.}

Body slender, slightly compressed; coxal plates comparatively small.

Mandibles strong, with palp of moderate size and having terminal joint slender. First maxillæ with inner plates small and furnished with a single apical seta. Maxillipeds with palp not very large.

First antennæ longer than second and provided with a distinct accessory flagellum.

Gnathopods in female comparatively small, the first pair being a little larger than the second pair; propodus imperfectly subchelate; that of second pair narrow and with palm nearly transverse and very short. First gnathopods in male greatly developed and with carpus extremely large and swollen, forming with the propodus and dactyl a kind of chela. First and second pereiopods glandular. Three posterior pereiopods rapidly increasing in length and with basal joint but little expanded.

Terminal uropods not extending beyond the others; rami sublinear and sparsely spinous. Telson large and thick, oval with a dorsal fascicle of spines on either side of the obtusely rounded tip.

\section{Microdeutopus gryllotalpa Costa.}

I853. Microdeutopus gryllotalpa, Costa, Rendiconto d. Soc. Reale Borbonica, Ac. d. Sci., n. ser., vol. 2, p. I78.

I873. Microdeutopus minax, Smith, Rep. U. S. Com. Fish., vol. I, p. 562 .

I896. Microdcutopus gryllotalpa, G .O. Sars., Crust. Norway, vol. I, p. 543, pl. 192, fig. 2.

Eyes small, round, deeply pigmented.

First antennæ more than half as long as body; second joint of peduncle a little longer than first and as long as head, third joint short; principal flagellum slender, of about twenty segments and longer than peduncle; accessory flagellum one-jointed and not as long as first joint of principal flagellım. 
Second antenne three-fourths as long as first, with fourth and fifth joints of peduncle subequal and nearly twice as long as third; flagellum slightly longer than last joint of peduncle and made up of seven joints.

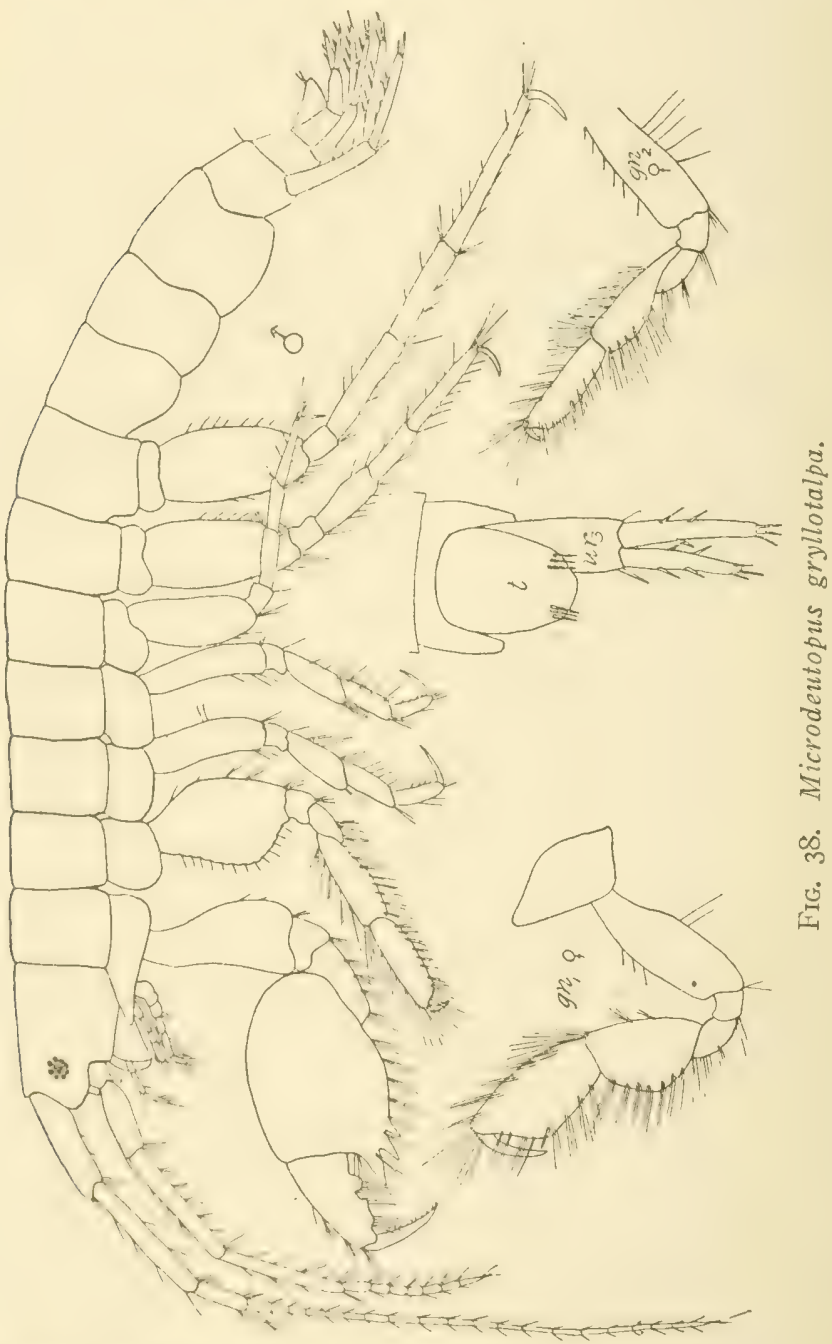

In male: first gmathopods very strong; carpus oval and longer than hasal joint, posterior margin produced to form a prominent 
triangular process proximal to which are two smaller ones; propodus twice as long as wide, tapering slightly, posterior margin very irregular, bearing several rounded prominences; dactyl long and slender. Second gnathopods with basal joint irregularly oval in form with front margin crenulated; carpus long and slender, rectangular; propodus subrectangular, slender, not as long as carpus, palm slightly oblique; dactyl short; carpus and propodus densely setose.

In female: first gnathopods not as strong as in male; carpus broadly oval; propodus suboval, slightly longer than carpus but narrower, palm straight, oblique, with prehensile spine.

Third pereiopods very short, fourth and fifth increasing in length and with basal joints expanded.

Coxal plates lower than their respective segments; first pro. jecting well forward to form a slender triangular process.

First pair of uropods extending as far posteriorly as last pair, with the peduncle and subequal rami provided with stout spines on dorsal margin; rami styliform and equal in each case to the peduncle in length.

Telson broadly oval, slightly longer than broad and with rounded apex provided with a group of three spines at the postero-lateral angle.

Body densely variegated with a dark brownish pigment.

Length $8 \mathrm{~mm}$.

Distribution: European coast from Norway to the Mediterranean; Provincetown (Rathbun); Woods Hole, Massachusetts ; Vineyard Sound; New Haven (Smith), Noank, Noank Harbor, Connecticut; Long Island Sound.

The species occurs among hydroids and algæ, on piles and in eel-grass. A few specimens in the collections studied, had been taken at the surface, Noank Harbor, in the evening, July I3, I874.

\section{Microdeutopus damnoniensis (Bate).}

1856. Lembos damnoniensis, Bate, Rep. Brit. Assoc., Meeting $25, \mathrm{p} .58$, pl. 17 , fig. 9 .

I903. Microdentopus damnoniensis, Holmes, Amer. Naturalist, vol. 37 , p. 290.

1905. Microdeutopus damnoniensis, Holmes, Bull. U. S. Bur. Fish., vol. 24, p. 515. 
This specis may le readily distinguished from the preceding onc ly the hiarticulate accessury flagellum of the first antenne; ly the nure slender first ginathopods of the male, the more dongatcul carpus, and different form of the carpal process which is natrowly trimgular, acute, and with a small tooth near the base of the pusterior margin; by the less elongated propodus of the second gnathopods; and the longer and more slender terminal pereiopods. .

Length $6 \mathrm{~mm}$.

The species las been recorded from Norway, the British Isles; and Woods Hole, Massachusetts.

\section{Lembos Bate.}

Body slender, coxal plates of medium depth.

first antenne much longer than second with flagellum long and accessory flagellum well developed.

Lower lip with mandibular processes strongly produced. Mandibles with both incisive plates dentate, molar tubercle strong; third joint of palp longer than second. First maxille with inner plate snlall and bearing a single apical seta; second joint of pally with several spine-teeth. Maxillipeds with plates generally well developed; fourth joint of palp not stout.

First gnathopods in male with merus not elongate; carpus and propodus stout, subequal in width, strongly setose, palm of latter with tooth-like projections. First and second pereiopods glandular. I'osterior pereiopods with basal joint not very widely expanded.

Third uropods with rami much longer than peduncle and equal. Telson simple.

\section{Lembos smithi (Holmes).}

Ioo3. Antonoi smithi, Inlmes, Amer. Naturalist, vol. 37, p. 290.

Io0.5. Autonee smithi, IIolmes, Bull. U. S. Bur. Fish., vol. $24.1 \% .516$.

Iyor. Lembos smithi, Stebling, Das Tierreich, Lief. 2 I.

Eyes oval, deeply pigmented.

First antemine nearly as long as body; first joint of peduncle as loner as head; second joint considerably longer than first and 
about three times as long as third; principal flagellum slender and longer than peduncle, provided with abundant setæ on lower margin ; accessory flagellum as long as terminal joint of peduncle, consisting of three joints. Second antennæ much shorter than first, but with longer peduncle; gland cone slender and not large, third joint twice as long as wide, fourth joint slightly shorter than fifth, which in turn is as long as the six- or seven-jointed flagellum.

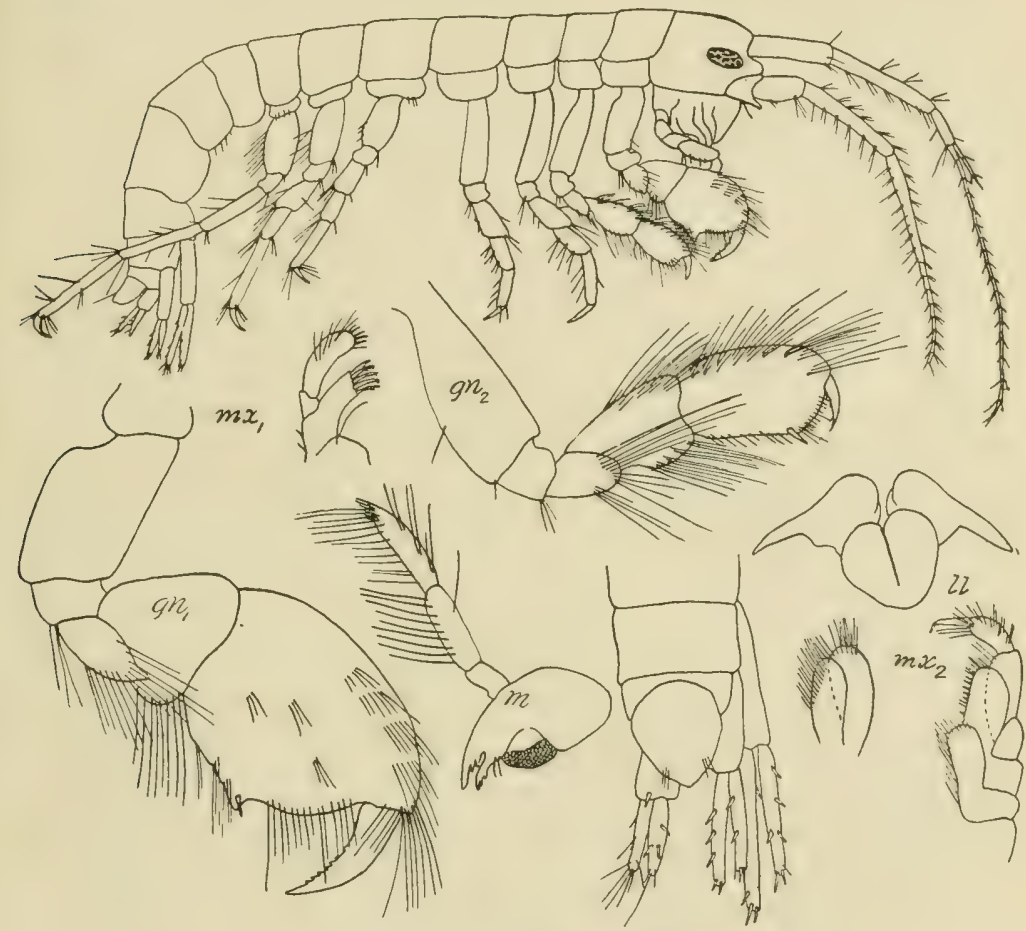

FIG. 39. Lemibos smithi.

Coxal plates small and provided with a few short setæ; the first four subquadrate and much longer than high.

First gnathopods very stout, with basal joint short, not more than twice as long as broad; carpus as broad as long and cupshaped, posterior margin densely setose; propodus broader and longer than carpus; oval in form, with palm sinuous, posterior angle prominent and armed with a stout,spine, posterior margin 
Short and markiel ly two prominences: dactyl stont and provided with many mimnte blunt tecth. Seeond gnathopods longer and mure semiler than first; carpus densely setose, triangular with anterion margin strongly convex; propodus also densely setose, rotangulat and about ats wirle as carpus but scarcely as long, falm short, transwerse, convex with a spine at rounded posterior angle; dilctyl previled with several short setre on concave margin.

loir-t two pereiopeds with spinning glands and basal joints l. nes and natrow ; mertws broadened distally and projecting beyond the carpun which is expul in length to the propodus; terminal juint very slichly curvel. Third, fourth, and fifth pereiopods increasing successively in length; second joints slender.

l'ostero latcral angles of first three abdominal segments rounded.

First pair of urupods slender, with rami equal to the peduncle which hears a slender, curved projection nearly half as long as rami : scomel uropols extending at far as first and of similar inm lut with much shorter peduncle; third uropods with rami which are much lenger than the pedmele and provided distally with lones sender spines ; peluncle without terminal prolongation. Telonin thick, nunded distally, wider than long and with several long setre.

Holmes describes the color as follows: "body and coxal flate with blackish pigment, the fifth thoracic segment lighter than whe others: athomen lighter than thorax; legs transparent and almost devoid of pigment: boxly and appendages with a difine redulish-brown coloration, which is deeper on the large hand, lecominge more intense toward the tip and on the base of the dacty dorsal side of body crossed with purple, orange, or rose colored hars: both pairs of antenne very beautifully and com-picmusly matied with spots of red, pink, or orange, these sputs on the perluncles of buth antennix at the base of the setre, on the flagellum of first antenne; they are regularly arranged, a gair of ohlone spots being separated by a colorless longitudinal interval on each joint."

Length $6 \mathrm{~mm}$.

Distribution: (ape (ond to I Iatteras, Vineyard Sound (Smith), "in tulues, in masies of a compound ascidian (Amouroucium filluidum) in 3-8 fathoms" (Verrill); Long Island Sound. 


\section{PHOTID瓜。}

Fourth coxal plates not excavate behind.

First antennæ sometimes as long as second, sometimes longer; accessory flagellum varying from long to obsolete.

First and second gnathopods either subchelate or simple; first never larger than second. First and second pereiopods glandular. Fourth and fifth pereiopods longer than the others.

Terminal uropods uniramous; first and second biramous. Telson simple.

\section{Photis Kröyer.}

Posterior abdominal segments elongated and slender. Anterior pairs of coxal plates comparatively large and closely contiguous; fifth pair scarcely smaller than preceding pairs.

Eyes small. Antennæ subequal, and generally densely setiferous posteriorly, peduncles elongated; first pair with no accessory flagellum.

Mandibles with elongated palp laving terminal joint comparatively short and densely setose.

Gnathopods distinctly subchelate; the second pair being somewhat larger than the first pair. First and second pereiopods glandular. Third pereiopods stout and strongly reflexed, with basal joint bollly curved anteriorly and dactyl inverted.

Last pair of uropods slender and extending beyond others; rami very unequal, the inmer one being very minute, the outer one elongated and having a small terminal joint. Telson extremely small, triangular.

'Photis reinhardi Kröyer.

1842. Photis reinhardi, Kröyer, Naturh. Tidsskr., vol. 4, p. I 55 .

I894. Photis reinhardi, G. O. Sars, Crust. Norway, vol. I, p. 569, pl. 202.

Eyes elongated, situated on prominent interantennal lobes; head not as long as first two thoracic segments together. First coxal plates somewhat attenuated distally and rounded at the tip. Second to fifth coxal plates taller than their respective segments; fifth bilobed, posterior lobe small. 


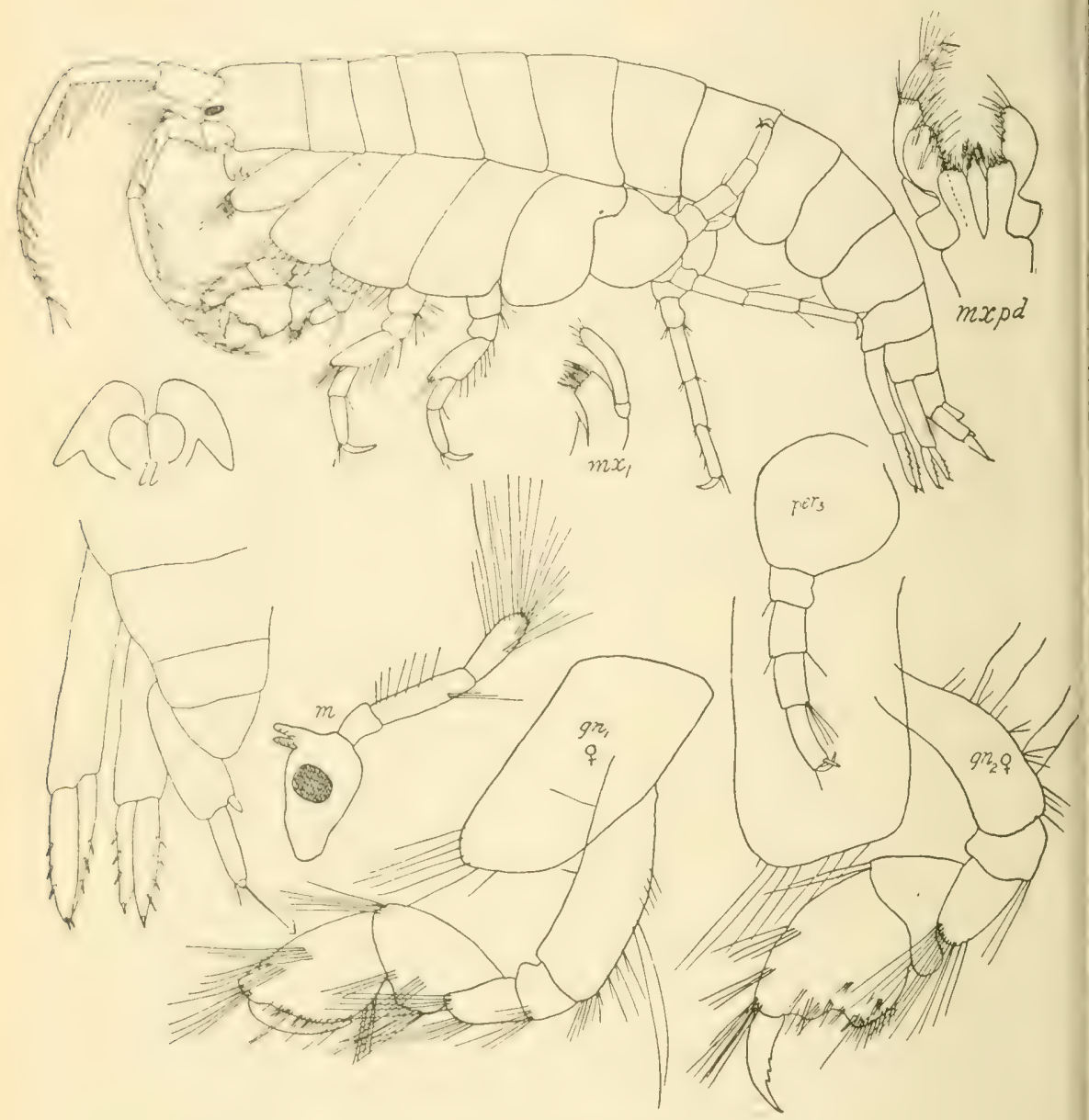

FIG. 40. Photis reinhardi.

Antemine stout and setose. First antennæ half as long as body and a little longer than second pair; second joint of peduncle the longest; third joint a little longer than first which is much stouter than the succeeding ones; flagellum of about eight joints, more than half as long as peduncle. Second antennæe with flagellum of about six joints, not as long as last two joints of peduncle.

First gnathopods of female robust, with carpus expanded behind into a broad lobe provided with long setx; propodus a 
little longer than carpus, broad, oval quadrangular in form; palm oblique and convex and longer than hind margin; dactyl strong and denticulated within. Second gnathopods more strongly built and with larger propodus than first pair; carpus short, with lobe much narrower than in first pair; propodus with the palm somewhat sinuous and defined behind with a distinctly projecting angle and a stout spine; dactyl stout, with several serrations within. Gnathopods in the male considerably stronger than in female, with propodus comparatively larger; palm of first pair slightly excavated; in the second pair much shorter than the hind margin and defined by a strong acuminate process. Pereiopods stout. Third pair with propodus slightly expanded distally forming a kind of palm armed with a slender spine against which the short, stout dactyl strikes; last two pairs of nearly equal length, with basal joints oblong oval in form.

Last pair of uropods with the outer ramus scarcely as long as peduncle, biarticulate, with terminal joint very minute and tipped with a long spine; inner ramus minute. Telson less than twice as broad as long, triangular in form.

Length $5 \mathrm{inm}$.

Distribution: Arctic Ocean, Greenland, Iceland, Norway. I met with a single female specimen from Long Island Sound in the collection in the U. S. National Museum obtained from the region about Noank, Connecticut.

\section{Podoceropsis Boeck.}

Antennæe slender and subequal in length, peduncles elongated, densely setiferous, no accessory flagellum.

Nandibular palps elongated and fensely setose. Other mouth parts normal.

Gnathopods very unequal, the first pair being feeble; the second pair being much larger and very powerfully developed in male. Posterior gnathopods with basal joint moderately expanded. First two pereiopods glandular.

Last pair of uropods scarcely extending beyond the others; rami subequal. Telson rounded, tubular. 
Podoceropsis nitida (Stimpson).

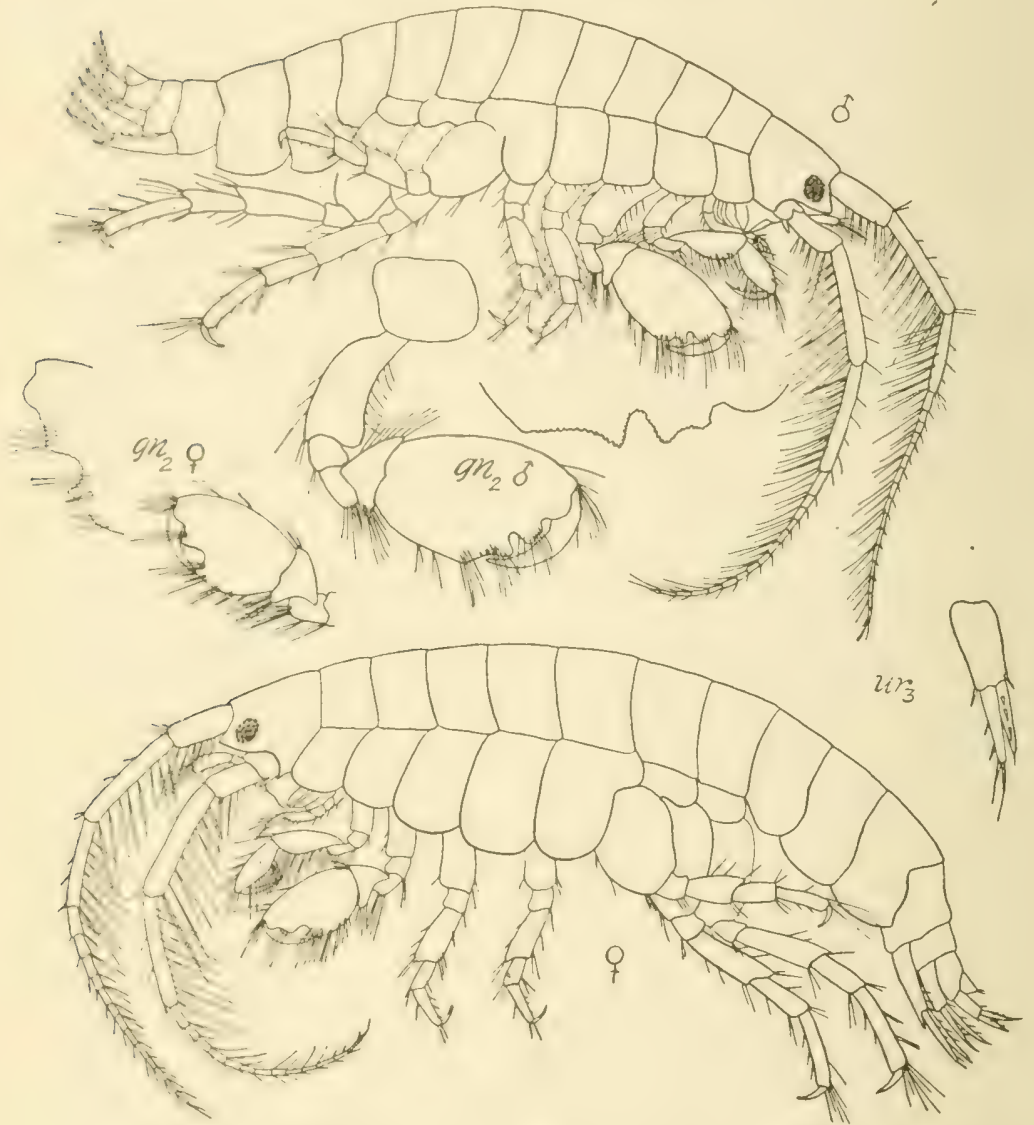

FIG. 4I. Podoceropsis nitida.

I 553. Podoccrus nitidus Stimpson, Smithson. Contr. Knowl,, vol. 6, No. 5, P. 45 .

18-7. Poducropsis excurata (Bate), Mènert, Naturhist. Tirl-lir. (3), vol. 1 I, 1). I 52 .

lifes aral, situated on rather prominent, acutely pointed interantennal lobes.

Intmua sulecpual in length, exceeding somewhat half the length of the body, and strongly setose. First antennæe with hatial juint of piceluncle stout and scarcely as long as third joint; 
second joint much longer than third; flagellum about as long as peduncle. Second antennæ with fourth and fifth joints of peduncle subequal in length, third joint hardly twice as long as wide; flagellum shorter than peduncle.

First two pereiopods with spinning glands; fifth coxal plate taller than fourth and with a small posterior lobe.

First gnathopods quite slender; carpus elongated and slender, setose; propodus shorter and narrower than carpus, more or less fusiform; palm not marked off distinctly from posterior margin ; dactyl very long and curved, closing against entire posterior margin. Second gnathopods large; carpus very short and cupshaped; propodus strong, suboval, palm finely tuberculated and oblique, with a rather deep rounded excavation at middle which is bounded by angular prominences, posterior margin setose; dactyl strong and curved, scarcely reaching posterior angle of palm. The male differs from the female in the fact that the angular prominence of the palm toward the hinge is broadly truncate and slightly emarginate, and the excavation is narrower than in the female.

First and second pereiopods with meral joints nearly as long as carpus and propodus combined. Third pereiopods with basal joint nearly as broad as long.

Postero-lateral angles of third abdominal segment with a very small projection.

First uropods with peduncle considerably longer than the styliform rami and with ventral margin prolonged to form a slightly curved spine projecting below rami; third uropods with rami equal in length to peduncle, extending as far posteriorly as first but not quite so far as second, inner ramus slightly longer than outer.

Telson as broad as long with group of three setæ on each side of rounded apex.

Length $7 \mathrm{~mm}$.

Distribution: Norway; British Isles; Grand Manan; Eastport, Maine; Rhode Island; Long Island Sound.

The species occurs at depths of $30-40$ fathoms.

Leptocheirus Zaddach.

Posterior portion of abdomen strongly built. Second pair of coxal plates greatly expanded. 
lirit antentuk longer than second, with well developed accessory flagellum.

Mambliles ind maxilla normal. Maxillipeds comparatively litrese with immer and outer plates small, and palp very slender with third joint very much elongated.

inathopods mequal in structure; first pair distinctly subchelate whit ischinm laminarly expanded. Second pair slender with iluse seta ilong front edge; carpus large; propodus short and tilpering without a distinct palm. First two pereiopods glandulitr and with propodus musually slender and elongated.

First and second uropods robust, and armed with strong muguiform spines; last pair small. Telson small and tubular.

\section{Leptocheirus pinguis (Stimpson.)}

I553. Ptiluchorus pinguis, Stimpson, Smithson. Contrib. Knowl., vol. 6, No. 5: p. 56.

IESS. I.eptocheirus pinguis, Stebbing, Rep. Voy. "Challenger," vol. 29, p. 279.

Body broad. Eyes oval or reniform.

First antenne longer than second pair but not so stout, last juint of peluncle short, second joint longer than the first; principal fluselim slender, composed of twenty or more segments, buner than the peduncle; accessory flagellum well developed. scomel prit of antenna with flagellum about one and a half times as long as last peduncular joint.

l:irst matheruls larger than the second: coxal plate prolonged comicicleribly anteriorly; carpus rectangular and as long as profurlus, will alense setae on posterior margin; propodus slightly hrobler distally than proximally, palm transverse, posterior matrin with dense setae; dactyl short and curved; carpus bent inwarel at nearly right angles to the proximal joints. Second wnathepurls with hasal joint slightly rounded in front and fringed will very long plumbse spines: carpus longer than propodus and smmewhat broaler, provided with very thickly set seta on hind matrin: propolus slightly tapering in form, with short palm and with hind margin densely covered with long setee. First and cocomel fereinguels with spinning glands, and subequal in size; thind, inuth, and fifth perioporls with lasal joints well rounded and increasing in length posteriorly. 


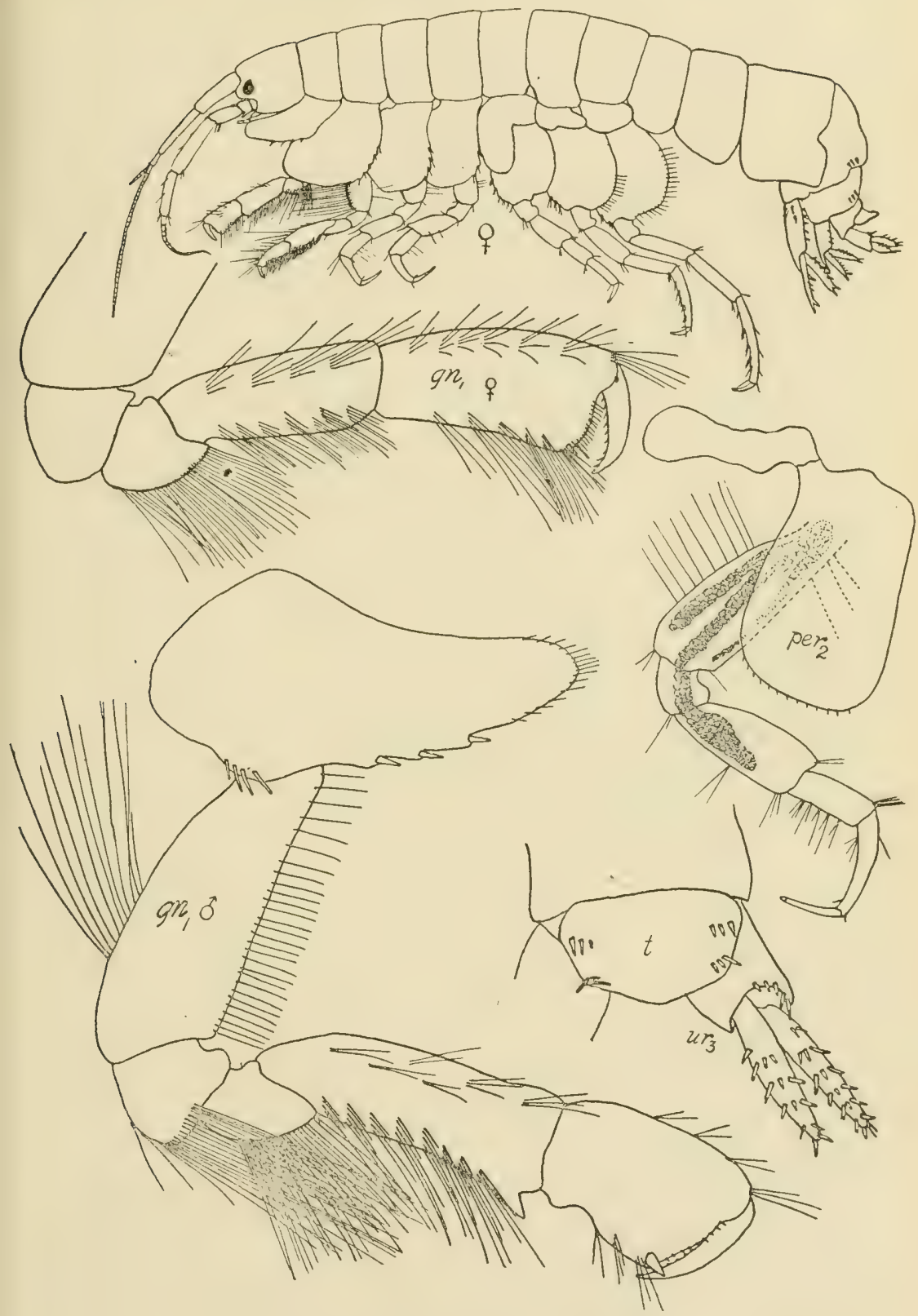

FIG. 42. Leptocheirus pinguis. 
[roynds limanums; terminal mair projecting beyond the utlers. rami amed dorsally and aplically with groups of spines; peluncle with smup of spines on upper apex. P'eduncles of lirst and scound pairs with a lons. curved, claw-like projection distally, extending leneath the ranil. Telson broader than long, agex romuled, undivided, postero-lateral angles with a tuft of spines in front of which is a row of three or four short spines.

Funrth and fifth abdominal segments provided with a group uf short spines near posterior margin at either side of middle line.

The color of this species is highly characteristic even in alcoholic specinems in which the head, body segments, the coxal plates especially in the proximal region, and the basal joints of the posterior pereiopods, are marked with chocolate brown grantes. 'There marlings on the body are usually in the form wi broad transyerse bands which may enclose irregular lighter areas. 'There is much variation in the amount of pigmentation. The eyes of alcoholic specimens are black.

Length $13 \mathrm{~mm}$.

1)istribution: east coast of North America from New England to Lalnater ; off $\mathrm{Xew}$ London, off Stonington, off Saybrook, Noank. Comnecticut: ofï Race I'onint; Fishers Island, 42 fathoms; Long Island Sound, 50 fathoms.

This is one of the most abundant of the Amplipoda of the New England coast; it is especially common on muddy bottoms. It occurs un the surface and, according to Smith, to depths of 50 fathoms.

\section{AMPHITHOID无.}

Interantennal lobes not very prominent.

Fomrih coxal plate not excavated behind; fifth with a broad front lobe as deep as the preceding.

First antenne with third joint short; accessory flagellum wanting or small.

I.wir lip with principal plates having a deep notch in front forming a broad sinus.

(inathopods not simple, second ustally larger than the first and larger in the male than in the female and differently shaped. 
First and second pereiopods glandular. Third pereiopods reverted. Fifth pair the longest.

Third uropods with short rami, the outer one of which is uncinate. Telson simple.

\section{Amphithoe Leach.}

Body slender, compressed, coxal plates of moderate size.

First antennæe without accessory flagellum.

Lower lip with outer plates incised at tip. Mandibles very strong; palp comparatively short, with terminal joint large and expanded and setose distally and on inner margin. First maxillæ with inner plate small and with a single seta. Second maxillx with outer lobe much larger than inner. Maxillipeds with moderately short palp.

Gnathopods subchelate. First two pereiopods glandular. Posterior pereiopods increasing successively in length with propodus simple.

Last pair of uropods with peduncle massive; rami subequal in length, the outer one lamellar and armed with two unguiform spines, the inner one conical in form. Telson of moderate size with a small projection on either side of the tip.

\section{Amphithoe longimana Smith.}

1874. Amphithoe longimana, Smith, Rept. U. S. Com. Fish., I 87 I -2, p. 563 .

Body slender. Eyes round and, in life, red.

First antenne slender and as long as body; second joint of peduncle longer than first and nearly twice as long as third; flagellum about twice as long as peduncle. Second antennæ stouter than first, especially in male, and somewhat shorter; peduncle much elongated, last joint considerably longer than preceding one and about as long as flagellum.

First five coxal plates much deeper than their segments; the first one prolonged in front; the three following plates oblong.

First gnathopods in male unusually elongated; carpus long and narrow with setæe on hind margin; propodus three times as long as wide and as long as carpus but hardly as broad, palm short and transverse, posterior margin slightly concave and covered densely with setæ; dactyl large and projecting well be- 


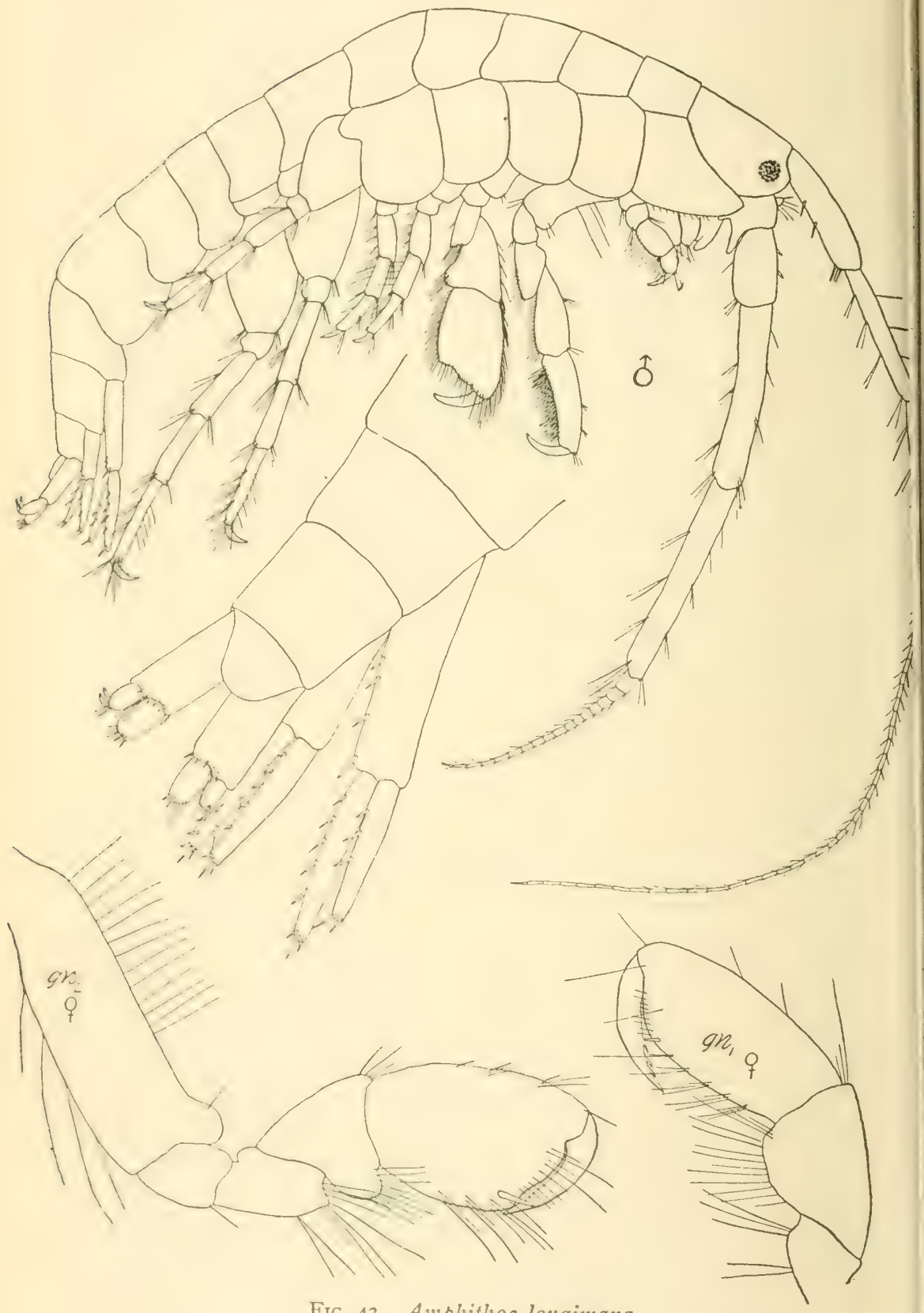

FIG. 43. Amphithoe longimana. 
yond the palm. Second gnathopods very strong; carpus subtriangular, much shorter than propodus which is oblong and broader than in first pair, and slightly broader distally than proximally, front and hind margins setose, palm oblique and concave, with prehensile angle prominent. Gnathopods in female comparatively small; first pair with propodus oblong and longer than carpus, and palm oblique and rounded behind where it is armed with a strong spine; dactyl projecting beyond palm but not nearly so far as in the male. Second gnathopods with carpus produced behind into a narrow lobe which is setose distally; propodus oblong, shorter and broader than in first pair, palm oblique, prehensile angle rather prominent and armed with a stout spine.

Terminal uropods with outer ramus shorter than inner, and armed apically with two hooked spines; rami less than half as long as peduncle.

Color bright green, pale green, bluish; nearly colorless to dark reddish brown.

Length $9 \mathrm{~mm}$.

Distribution: Provincetown (Rathbun), IVoods Hole, Vineyard Sound, New Jersey; Noank Harbor, north of Fishers Island, Long Island Sound.

The species is not uncommon among seaweed near shore and in sheltered places, and has been taken at the surface in the tow-net at Woods Hole and Noank. It is not common on eelgrass near the roots but seems to prefer the masses of eel-grass nearer the surface.

Professor Holmes has described the habits and natural history of the species fully in the Biological Bulletin, vol. 2, p. I65193, to which the reader is referred for details.

\section{Amphithoe rubricata (Montagu).}

I808. Cancer Gammarus rubricatus, Montagu, Trans. Linn. Soc. Lond., vol. 9, p. 99, p1. 5, fig. I.

1853. Amphithoe maculata, Stimpson, Smithson. Contrib. Knowl., vol. 6, p. 53 .

1874. Amphithoe valida, Smith, Rept. U. S. Com. Fish., I87 I-2, p. 563 .

Body stout, robust; interantennal lobes blunt. Eyes small, round or oval. 


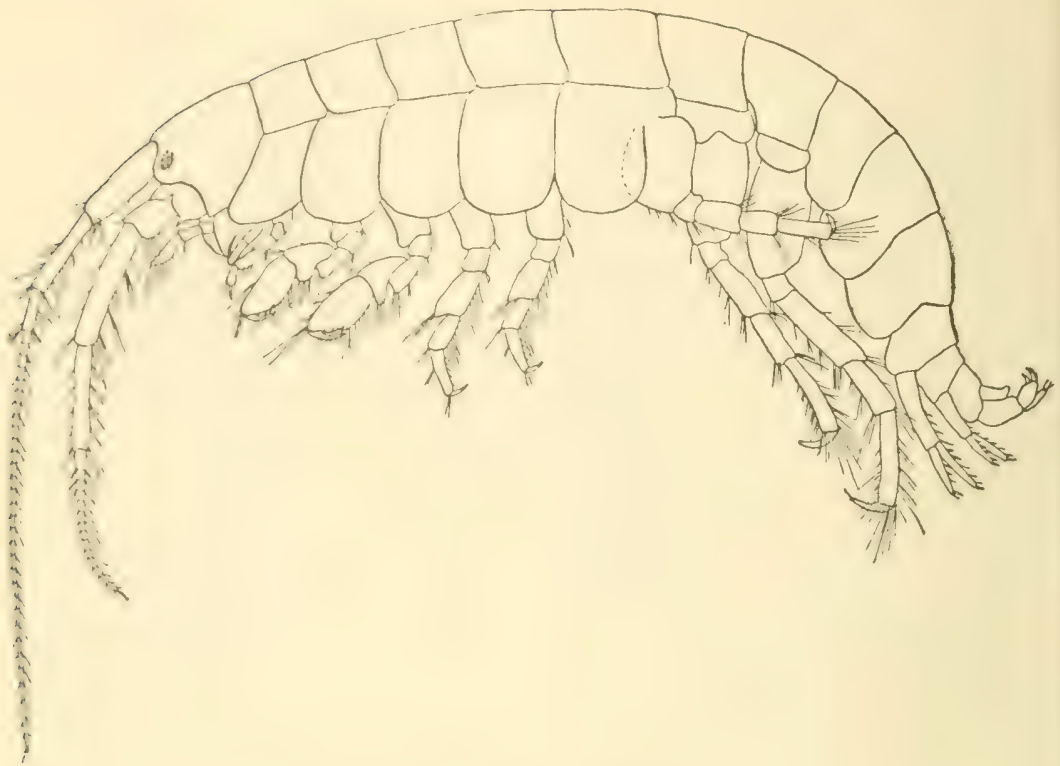

FIG. 44. Amplithoe rubricata.

First antenna nually more than half as long as body; first and second perluncular joints subequal and each one twice as long as the last one: flagellum slender and longer than peduncle. seomel antenne decidedly stout, shorter than the first in female, relatively longer in the male; last joint of peduncle as long as precoling: flatedlum short and thick, composed of few joints, and often less than half as long as peduncle.

Cowal plate of first gnathopod produced bluntly forward; first live deeper than their respective segments; fourth pair not cxibate hehiad: fith patr with hroad front lobe as deep as preceding.

first snathepuds in the male strut. with hasal joint short aml proflucel inte a prominent fole at antero-distal angle; proforlus whlonge with paln olligue and convex and with posterior ansle remuled and amed with a spinc. Second suathopods with froml hasal juint with distal luke smaller than in first pair; proforlus stout and proviled with a tuit of setse at the apex, palm whipue, convex toward apex, concave toward prehensile angle which is produced. In the female, first gnathopods with carpus 
shorter than in male and propodus narrower, but otherwise quite similar in form. Second gnathopods with propodus resembling that of male but less densely setose apically, palm with a strong prehensile spine. Third pereiopods with basal joint broader than long.

Third segment of abdomen with postero-lateral angles rounded.

First and sccond uropods spinose; first pair with peduncle longer than rami. Third pair with peduncle twice as long as rami; outer ramus with two strong hooks apically, inner ramus narrower than outer, with two lateral spines and an apical one and several setre. Telson as broad as long, apex rounded, between two little tubercles, within which are three setules on each side.

The color of the species varies from green to reddish; generally there is a row of light colored spots along the mid-dorsal line, one spot for each segment.

Length $20 \mathrm{~mm}$.

Distribution: Norway; England; France; Azores ; Labrador; Bay of Fundy; Grand Manan; Woods Hole, Massachusetts; Newport, Rhode Island; Noank, New Haven (Smith), Long Island Sound, north of Fishers Island, off Stonington, Connecticut.

The species occurs under rocks and in algæe at low tide on muddy shores and to depths of 9 fathoms. It occupies tubes covered with sand and bits of algæ, attached to the underside of stones at low-water mark.

\section{Grubia Czerniavski. $=$ Cymartuza}

Like Amphithoc but first antennæe have a uniarticulate accessory flagellum and second antennæ an elongate flagellum. Mandible with third joint of slender palp not distally expanded.

\section{Grubia compta (Smith). = Cyw}

I874. Amplithoe compta, Smith, Rep. U. S. Com. Fish. for I87 I-2, p. 564 .

I905. Grubia compta, Holmes, Bull. U. S. Bur. Fish., vol. 24, p. 5 IO.

Eyes round, situated on interantennal lobes. 
[Bull.

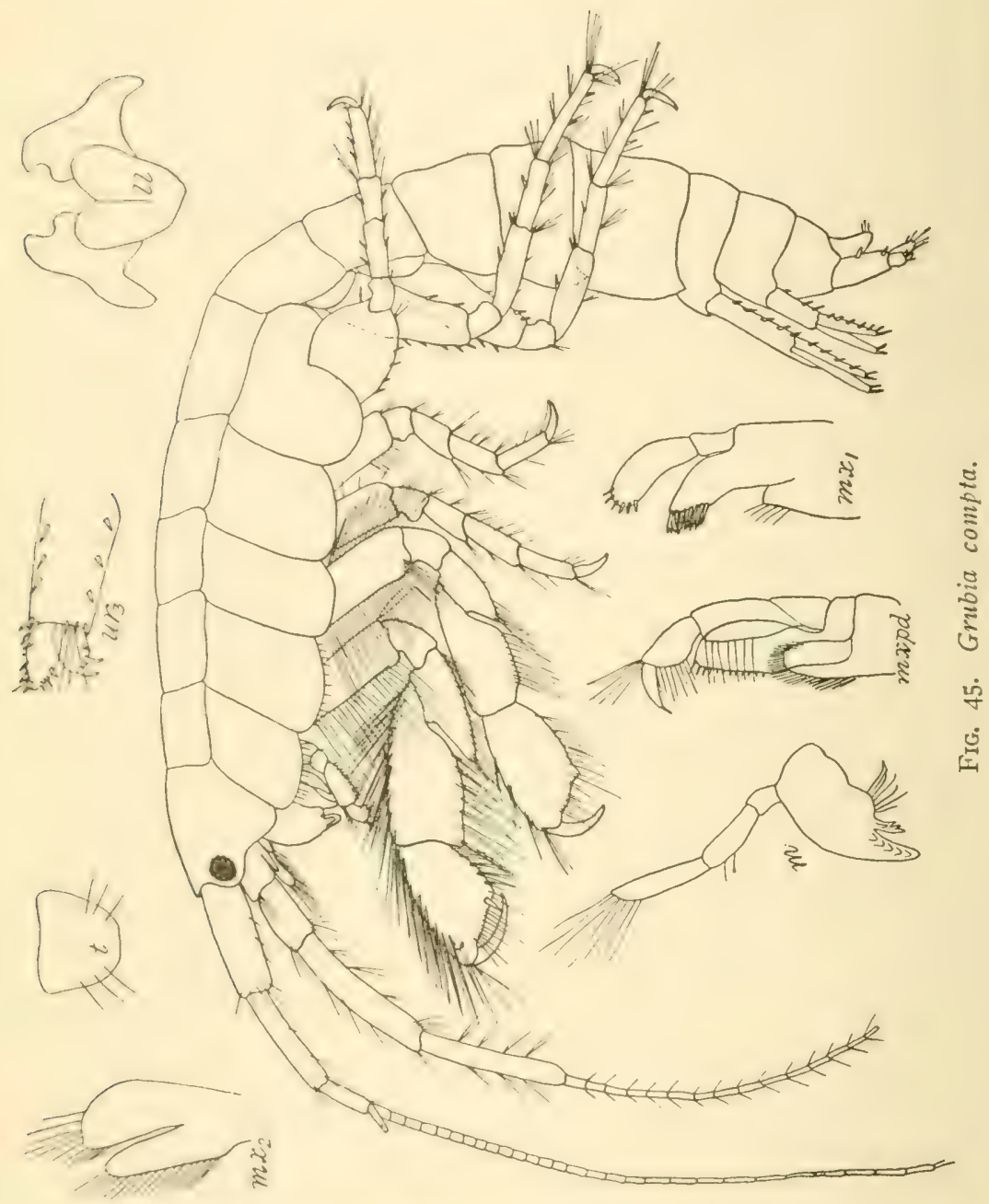

lirst antennat longer than second, with first and second joints of perluncle stulecpual in length and twice as long as third. Flagellum longr and slender: aceessory flagellum short, one-jointed. Second antenne slender with elongated peduncle.

Mandibles with the jointed palp, the distal one of which is whe cularger distally. Iomer lip with onter plates incised. fir-t matla with small triangular inner plate having a number 
of setæ on inner margin and with a two-jointed club-shaped palp. Maxillipeds with four-jointed palp and plates well developed.

First five coxal plates large, first four oblong and first not produced greatly anteriorly; all much deeper than their segments ; fifth coxal plate bilobed.

Gnathopods of male greatly elongated and provided with abundant plumose setæ, first pair as large as second; fourth joint with posterior margin produced to form a rather slender triangular process which fits behind the very long subtriangular carpus; propodus oval, considerably smaller than carpus, palm oblique, nearly straight and armed with a stout prehensile spine at the rounded posterior angle, dactyl long and curved. Second gnathopods with merus and carpus smaller than in first; propodus oblong, with a sinuous palm and posterior angle produced; dactyl shorter and stouter than in first.

Gnathopods of female of nearly equal size and similar form, much smaller than in male; carpus as broad as, and longer than, propodus which is narrowed at the proximal end and expanded distally, palm oblique and rounded posteriorly where it is armed with a spine.

First pair of uropods with styliform rami; nearly as long as peduncle and provided with spines on upper margin; peduncle bearing a slightly curved prolongation distally below rami; second uropods with rami as long as peduncle; third uropods with short, stout rami the outer one of which is shorter than the inner and provided distally with two strongly curved hooks; inner ramus about one-half as long as peduncle.

Telson thick, triangular with rounded apex, provided with several setæ at distal corners.

Color variable, about as in Amphithoe longimana.

Length $12 \mathrm{~mm}$.

Stebbing (1906) erroneously. refers this species to the genus Amphithoides Kossmann from which genus Grubia differs by having two well developed hooks on outer ramus of terminal uropods and the terminal joint of mandibular palp not enlarged.

The species occurs generally from Cape Cod southward to North Carolina, being especially common in eel-grass. 


\section{JASSIDE.}

Interantemal bules oflen somew hat prominent. Fourth coxal plates usually not excavate behind.

lareng bagellum of first antenna never large, often indistinct.

Thine junit of mandibular palp shorter than second, laminar.

(inahlipuls suludelate, second pair larger than first, often (2reatly molitiel in the male. First and second pereiopods glandular; third pair reverted; fifth pair the longest.

Third uropods with very short rami of which the outer is uncinate and ustally surmounted by denticles. Telson simple.

\section{Jassa Leach.}

Finnth coxal plates not perceptibly emarginate behind.

Antenne setose, with flagellum shorter than elongated peduncle. First antenne with first joint of peduncle shorter than second or third; acessory flagellum very small. Second antennæ usually considerably larger than first.

Mandililes with large palp having third joint shorter than scomel, distally widened, and densely setose. First maxillae with immer plate very small and provided with marginal setac second joint of palp long.

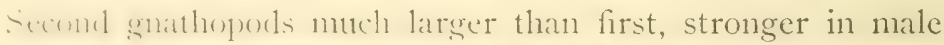
than inale: hind naresin of propodus of male produced into it strome truth. Fir-t and second pereiopods glandular with hatal jum - li huly expanded. I'osterior pereiopods with basal joint somewhat expanded.

First and second uropods with outer ramus shorter than inner. Thirel nroporls with stout peduncle nuth longer than rami, the outer one of which ends in a hooked spine. Telson triangular.

\section{Jassa marmorata Holmes.}

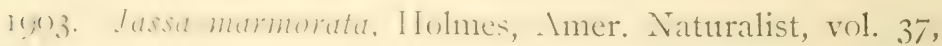
p. 289.

Iyo5. Iasis mamomatu, IIolmes, Bull. U. S. Bur. Fish., vol. 24 , p. 5 II

Hearl prufuced into a small, broadly triangular rostrum. Burly molerately depressed. First two coxal plates as deep as 
their segments, third pair the largest. Eyes round, situated on the prominent interantennal lobes.

Antenna stout, their lower margins with long setæ; first pair shorter than second pair, first joint of peduncle much shorter than second which is a little longer than the third; flagellum not much longer than last joint of peduncle, composed of five or six joints; accessory flagellum minute, consisting of a single joint. Second antenna very stout, with last joint of peduncle a little longer than preceding one; flagellum about three-fifths as long as last joint of peduncle.

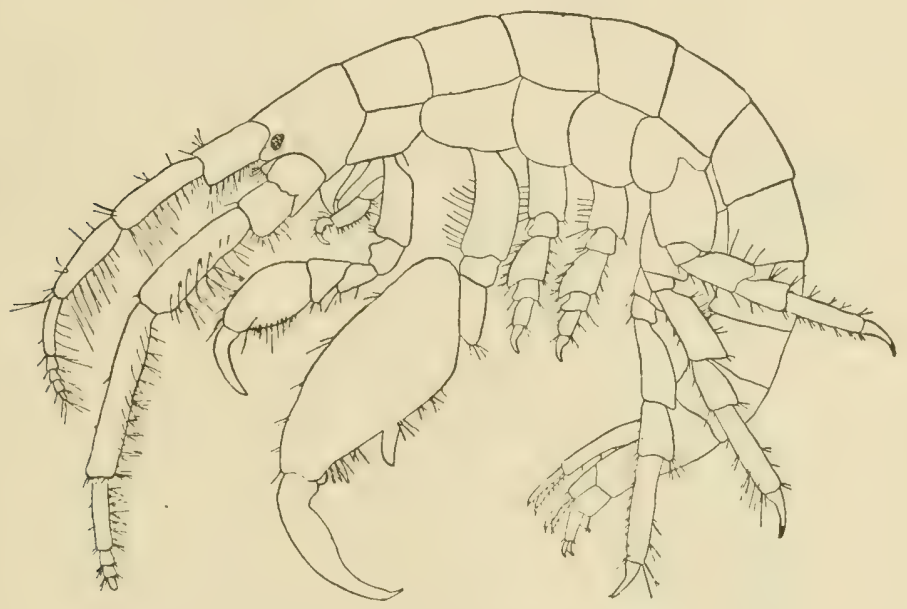

FIG. 46. Jassa mamorata.

First gnathopods in both sexes with propodus ovate, palm very oblique, with a row of three prehensile spines. Second gnathopods with propodus enormously developed and produced at proximal end of palm into a long, narrow, thumb-like process, lower end of palm with a triangular process. In the female the second gnathopods are much smaller than in the male, propodus oval in outline, with front margin very convex and palm concave. First and second perciopods with merus much dilated and produced downwards in front.

First uropods with peduncle having a large spine on the lower margin nearly half the length of the rami. Last pair with rami half as long as peduncle. Telson broader than long, apex rounded 
and cntire and provided on either side with a minute spine and one or two setæ.

The species is complicuously mottled. The ground color is reddish, the spots are of a lighter color.

Length of large male io mm.

D)istilution: Nihant, IVods Hole, Gay Head, Vineyard Haven, Massachusetts; New Haven, Connecticut.

The species oculrs frequently among hydroids and algre on piles hut hats also been collected at the surface, in tide-pools and on sandy and muddy bottoms.

I was unable to examine the specimen from New Haven Which was collected and identified by Dr. W. K. Longley.

\section{Ischyrocerus Kröyer.}

- imilar to insulexeept as follows. Second coxal plates not ditierently shaped from third. Second gnathopods in female a little larger than lirst; in the male with hind margin of propodus not produced into a prominent decurrent tooth.

\section{Ischyrocerus anguipes Kröyer.}

I894. Ischyroccrus anguipes, G. O. Sars, Crust. Norway, vol. I, p. 588 , pl. 209.

I874. Podocerus fucicola, Smith, Rep. U. S. Fish. Com., I8 5 I-2, p. 565 .

Eyes nearly round.

First antenne considerably shorter than second, peduncle with scomel joint a little longer than third and nearly twice as long as first flacellum shorter than last two joints of peduncle; accessory flagellum very small, consisting of an elongate joint tipped by a very minnte one. Second antenne stout and elongate; peduncle with last two joints subequal; flagellum shorter than last iont of peduncle and composed of five or six joints of which the first is the longest.

First four coxal plates subquadrate, and as deep as their respective segments.

First gnatherpuls in male small: hasal joint broad; carpus rumcled and setose behind; propolus subovate, with palm very alicpue and nearly straight, posterior margin with a row of spines which begins at the palm; dactyl with inner margin finely 


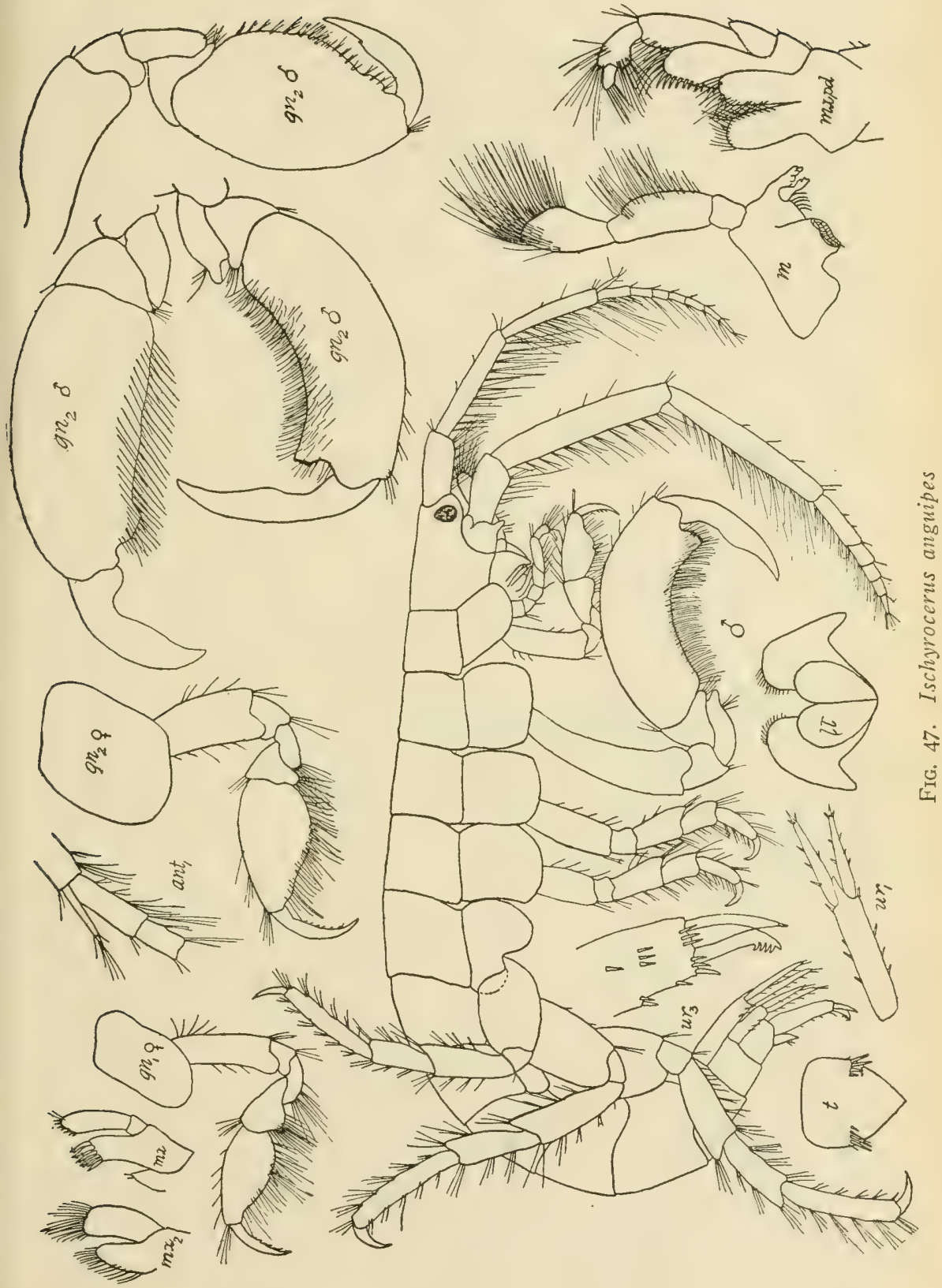


sermite. Second gnathopods in male very large, much elongated; lawil joint narrow, elongate, gradually widening distally and curvel forwarl, lower anterior angle produced downward in a rounded fole: ischimm produced anteriorly into a prominent rumbled lule as in first gnathopods; merus with pointed process at infereposterior angle; carpus triangular, with an angular fosterior fropection which hears a fascicle of setre; propodus (Hingate, thichemed, curved hackward, posterior margin somewhat concatse and fringed with plumose sete and bearing a blunt frojection near distal end of segment. In the female, first gnathofuil: quite similar to those of male lut with basal joint narrower. The scond gnathopods are very much smaller than in the male and of very dilferent form; basal joint relatively broader and willuing more distally; meru; l)roadly rounded and setose behind; arpus sultriangular, short, produced behind into a setose lobe; duty narrowly ovate with palm slightly sinuate and provided with two prehensile spines.

Firt mopuls with peduncle having a spine at distal end which is much less than half as long as rami terminal uropods with rami very small, scarcely one-fourth as long as peduncle. Telson triangular, with rounded apex.

In the female, hesides the differences in the gnathopods, the secomel antemie are much smaller than in the male, being only a little longer and stonter than the first pair; the body is also bromber in the niddle, and the second, third, and fourth coxal plates are somewhat deeper than long.

The color varies from light olive or greenish to light crimsoll. Sonne specimens, according to Smith, taken at WVatch Hill, likucle litund, " hat a transierse dorsal band of red or orange on eath sement, and similar ones on the epimera, and were minutely speclicul with dirk brown; the antennxe and legs were annulated with white and light red or orange."

Length Io $\mathrm{mm}$.

Instribution: Norway: Greenland; Labrador; Iccland; Silerian prolar acas; Grand Manan; Bay of Fundy; Marble Head Peach, Mas-achusctt: " I'rof. Smith states that this species was dreiged ly I'rufeseor lerrill in 4 to 5 fathoms off Watch Hill, Whorle Island, in April, I873;" Sea Flower Reef, Long 
Island Sound, July I7, I874; off Stonington, Connecticut, 4 to 6 fathoms, April, I873, rocky bottom.

In the shape of the second gnathopods of the male I find considerable variation quite similar to that described by Holmes for Jassa marmorata. In a series of specimens collected by Verrill off Stonington I found a number of intermediate forms between the typical form with the hind margin of the propodus of second gnathopod concave and the whole segment curved, to the less usual form in which the propodus is oval and relatively much wider than in the typical form. The series of specimens was not extensive enough to allow of a generalization regarding the significance of this variation.

\section{COROPHIIDA.}

Body usually depressed. Abdomen small. Coxal plates usually small and often not in continuity.

Antennæ of variable proportions, with or without an accessory flagellum.

Gnathopods-variable in form and relative size. First and second pereiopods usually glandular. Fifth pereiopods the longest.

First uropods biramous; second uni- or biramous. Third pair small, weakly biramous, uniramous or without rami. Telson simple, sometimes lobate.

\section{Cerapus Say.}

Body slender, abdomen depressed. Head with distinct rostrum. First four coxal plates very small; fifth and sixth larger.

First antennæ without accessory flagellum. Flagellum of first and second antennæ short.

Mouth parts normal.

First gnathopods subchelate. Second complexly subchelate and powerful in male, weak and simple in female. First and second pereiopods short, glandular, front margin convex; posterior pereiopods short, recurved, with very short, bidentate finger.

Second and third uropods uniramous, with ramus short and uncinate. Telson short, broad, bilobed. 


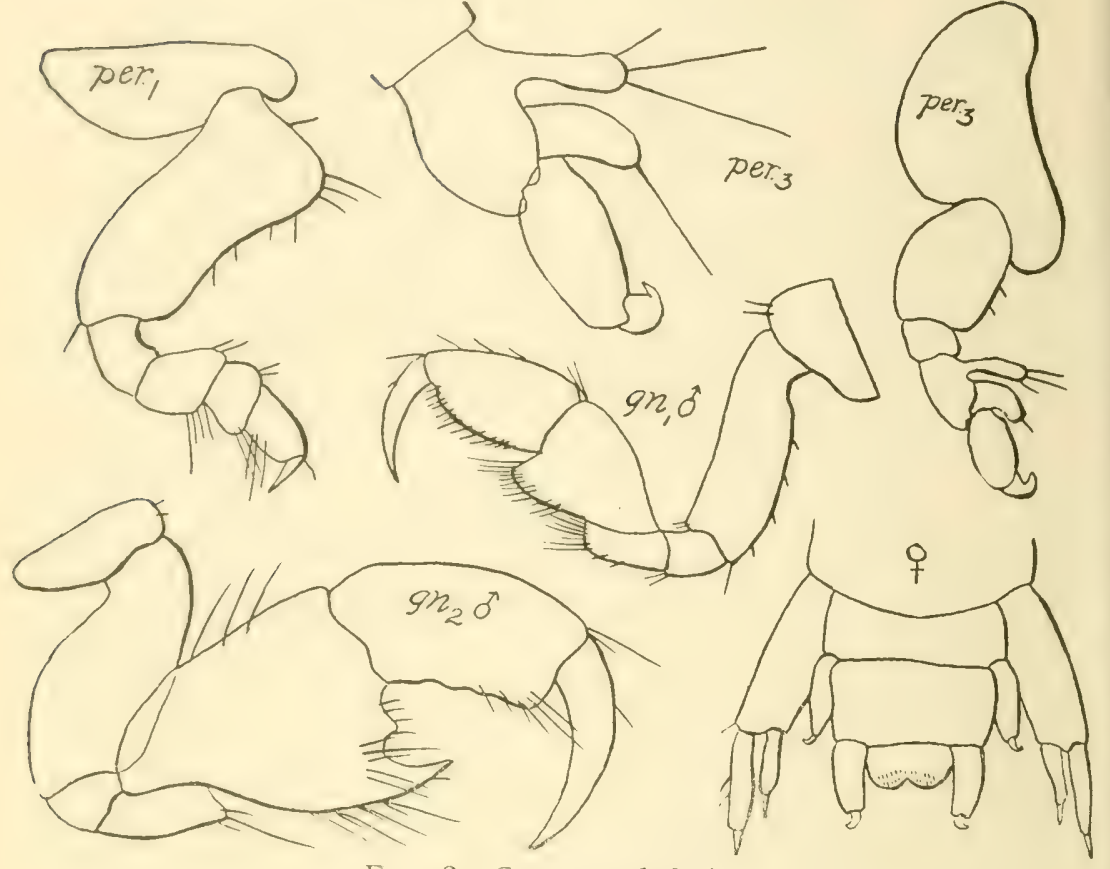

Fig. 48. Cerapus tubularis.

I8I7. Cerapus tubularis, Say, Jour. Phila. Acad. Sci., vol. I, pt. I, p. 50, pl. 4, figs. 7-II.

I880. Ccrapus tubularis, Smith, Trans. Conn. Acad., vol. 4 , pp. 269-277, pl. 2, figs. I-6.

Ileal with a small rostrum and a faint dorsal carina; body greatly depressed.

Eyes small.

First and second antenne subequal in length and in male a little orer half the length of the body. First segment of first antenua stout, laterally compressed, furnished below with a carima which is more prominent near the base; second and third joints sulectual and catch somewhat longer than first and subequal 11, the fligellum which is triarticulate. Second antenna, slightly horter than first and with triarticulate flagellum which is nearly as long as last joint of peduncle.

Coxil plates broader than deep; fifth pair the largest. 
First gnathopods with carpus produced downward at postero-distal angle into a small lobe; propodus oblong, narrower than carpus but about as long, palm oblique and spinose. Second gnathopods in male with carpus having front margin convex and furnished at its postero-distal angle with a large, acute tooth, above which js a rounded sinus separating the latter from a small rounded tooth; propodus oblong, slightly curved, nearly as long as carpus, hind margin irregular; dactyl large and stout.

Second gnathopods in female similar to first pair. Third pereiopods very small; merus with a long spatulate lobe on posterior margin; carpus articulated to posterior margin of merus above distal end of latter, and produced greatly beyond articulation of oblong propodus; dactyl short and broad with an abruptly recurved hook-like tip. Fourth pereiopods with basal joint as long as merus, longer than broad; fifth pair more slender.

First uropods with outer ramus much larger than inner; second pair about one-half as long as first, with a single ramus which is very short and furnished with a terminal hook; last pair much like preceding but stouter. Telson with two dorsal rows of sharp, upturned spinules, about twice as broad as long and distally emarginate.

Length $4.5 \mathrm{~mm}$.

Distribution: Great Egg Harbor, New Jersey; Vineyard Sound, Massachusetts, in masses of the compound ascidian (Amouroucium pellucidum) ; Noank Harbor, Connecticut; (Smith), Long Island Sound.

The species occurs also in eel-grass to depths of ro fathoms. Considerable numbers were taken at the surface in the evening at Noank Harbor, July 21, I874.

These animals construct thin cylindrical tubes which they carry about with them, thus differing from the great majority of tube-dwelling Amphipoda which inhabit a fixed tube. Professor Smith (Trans. Conn. Acad., vol. 4, pp. 269-277) has given a full description of the species with observations on its habits.

\section{Ericthonius Milne-Edwards.}

Body somewhat depressed, with very small coxal plates; abdomen narrow and elongated. 
Intemes slemder, subecpual, peduncle long; flagellum of several juint:; no acessory flikgllum; second antennæe attached much ixhind first; third joint of peeluncle mustally elongated.

Mandibles short and stout with palp much elongated and having teminal joint lamellar and densely setose. Maxillipeds with palps comparatively narrow.

(inathopdis fery unequal, the anterior ones small, with carpus complatively larec and expanded posteriorly; propodus short

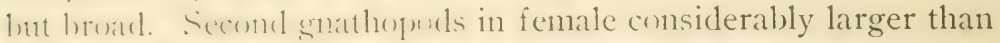
first and with carpus produced posteriorly; propodus expanded, with galm weil lefined. in the male of enormous size and complexly chelate, the carpus heing extremely large and bearing vertally an actuninate thumb-like process; propodus narrower than carpus and having palm imperfectly defined. Anterior pereiopods with basal joints lamellarly expanded.

Latst pair of uropods with a single lamellarly unguiform munus. Telsoin short and broad with two densely spinous processes above.

\section{Ericthonius rubricornis (Stimpson).}

I:53. Cirupus muricomis, Stimpson, Marine Invert. Grand Manan, Smithson. Contrib. Knowl., vol. 6, p. 4 z̆ fig. 33 .

ISSo. Erichthonius difformis, Smith, Trans. Conn. Acad., vol. 4 , p. 278 .

Eyes nearly round. Interantennal lobes projecting strongly forward.

First antennx sliglntly longer than second, with second and third freduncular joints subequal in length and not quite twice as long as first joint; flagellum short. Second antennxe with last joint of preduicle a little longer than preceding one; flagellum short and furnished with long setæ on lower margin.

First gnathopods with merus produced distally to a triangular frocess; carpus latre, widening distally; propodus smaller than carpus and greatly constricted at base, two-thirds as broad as long, palm slightly convex and finely serrated and passing gradually into posterior margin; dactyl strong, armed with a few short spines. Second snathopods in male very large, with carpus fmoluced below propolus into a large acute process; propodus whing, with a promineme near the distal end of posterior margin; 
in female carpus produced to a lobe, which extends behind the propodus nearly as far as the tip of the dactyl when closed, armed near distal end with several spines and numerous setæ; propodus ovate, palm very oblique, provided with many short setæ and several large prehensile spines.

First and second pereiopods short and provided with spinning glands; basal joints large, subovate, more convex in front than behind; merus expanded and produced downwards in front; dactyl long and slender. Last pair considerably longer than the preceding.

Second and third uropods with margins acute and serrate; terminal pair with a single subconical ramus which is curved and shorter than the peduncle and has two or three short spines at the tip.

Telson emarginate, lobes armed with numerous very short, hook-like spines.

Color, on the back dark mottled gray; coxal plates blackish. Length $9 \mathrm{~mm}$.

Distribution : Labrador; Grand Manan; Bay of Fundy; whole coast of New England. It is more common north than south of Cape Cod. Smith has reported it from Vineyard Sound.

The species inhabits flexible tubes composed of sand or mud stuck together with a small amount of adhesive material from the spinning glands.

It is found tisually in shallow water but may extend to depths of roo fathoms, according to Smith.

\section{Ericthonius brasiliensis (Dana).}

I853. Pyctilus brasilicnsis, Dana, U. S. Explor. Exped., vol. I3, pt. 2, p. 976, pl. 67, fig. 5 a-h.

1874. Cerapus minax, Snith, Rep. U. S. Com. Fish., I87I-2, p. 565 .

I906. Ericthonius brasiliensis, Stebbing, Das Tierreich, Lief. 2I, p. $67 \mathrm{I}$.

Eyes large, nearly round; interantennal lobes broad with a small apical point.

Antennæ of subequal length, more than one-half as long as body. First antennæ with last two joints of peduncle subequal and about one and one-half times as long as first; flagellum as 
long as perluncle and twelre-jointed. Second antennæe with last joint of perluncle a little longer than preceding one; flagellum nearly as long as peduncle and made np of about nine joints.

(i)xal plates contignous; the second and fifth being the largest.

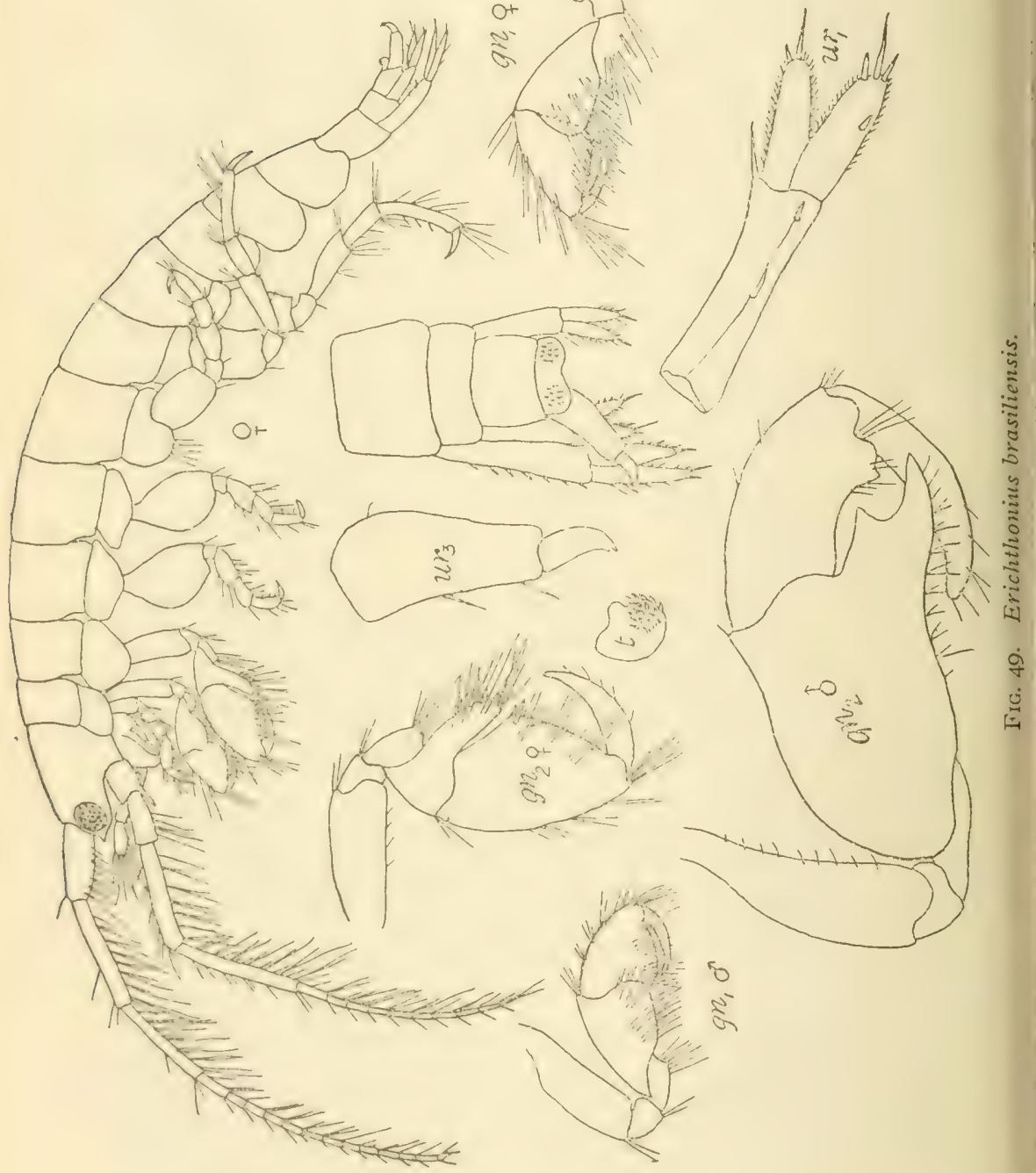


First gnathopods short, with large carpus widening distally and setose behind; propodus shorter than carpus, gently convex in front, quadrately rounded behind, palm subequal to hind margin; dactyl finely serrate. Second gnathopods in male very large; merus very small; carpus elongated, produced beyond propodus into a very large, acute process which has a very large tooth on its front margin; propodus much narrower but not much shorter than basal part of carpus, with a low elevation near distal end of hind margin; dactyl with long setæ apically. Second gnathopods in female with carpus produced behind propodus in a slender lobe which is armed distally with setæ and recurved spines; propodus large, palm oblique and longer than hind margin.

First uropods projecting beyond second and third; peduncle slender and much longer than rami; inner margin of peduncle of second uropods with acute serrations; margins of rami of second and third uropods acutely serrate, the serrations on inner rami being the larger; third uropods with peduncle broad at base and much longer than ramus which ends in two upturned spines.

Telson twice as broad as long, emarginate, with lobes armed with numerous, very short, hook-like spines.

\section{Length $6 \mathrm{~mm}$.}

Distribution; Europe, from Norway to the Adriatic; Rio Janeiro; Bermuda; Vineyard Sound; Woods Hole, Massachusetts; Great Egg Harbor, New Jersey ; Long Island Sound; New Haven (Smith), Noank, Connecticut, off Sea Flower Reef.

The species occupies tubes which are affixed to hydroids and algæ; it is more common according to the Woods Hole Survey at depths between 8 and 16 fathoms.

\section{Unciola Say.}

Body slender, depressed, with small angular, coxal plates.

First antennæ longer than second with an accessory flagellum. Second antennæ larger in male than female; flagellum multiarticulate.

Mandibular palps well developed, triarticulate. Maxillipeds with outer plates short and broad and armed inside with strong flattened spines. 
First pair of gnathopods much stronger than the second; fripulus large and bruad, sublhelate. Pereiopods comparatively scmeler. Three fusterior pairs having basal joint expanded.

Iast pair of uropods very small with peduncle expanded medially. Telson compraratively large, lamellar, rounded.

\section{Unciola irrorata Say.}

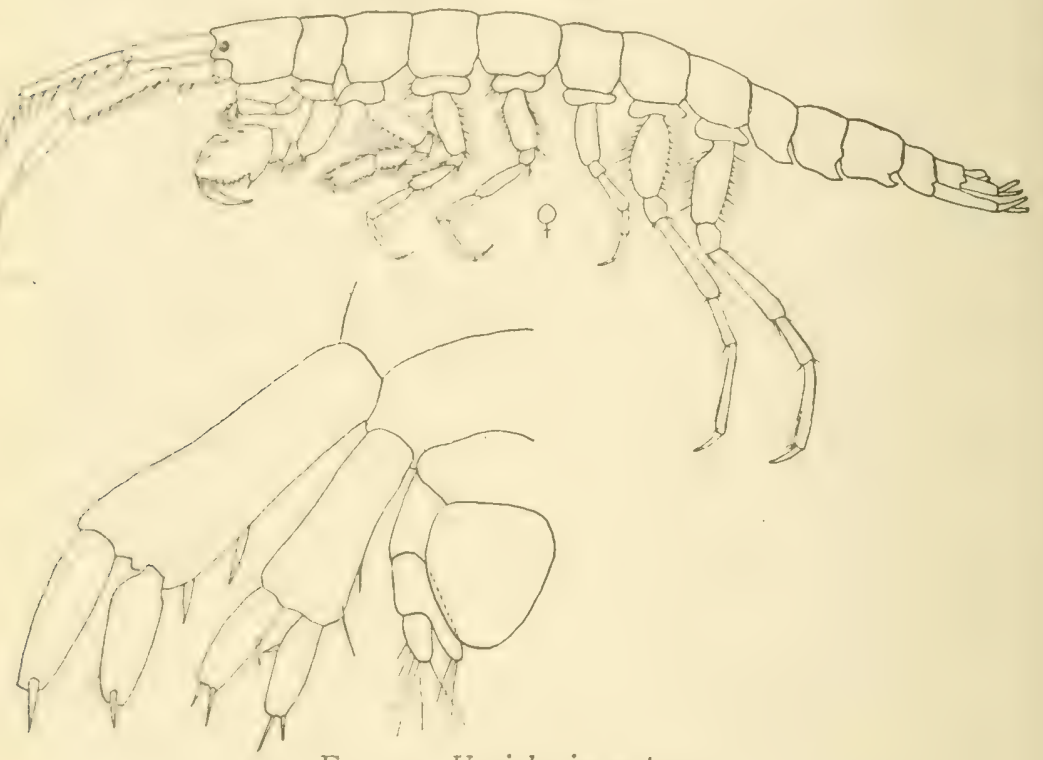

FIG. 50. Unciola irrorata.

I8I8. Unciola irrorata, Say, Jour. Acad. Nat. Sci. Phila., vol. $I$, pt. 2, p. 389.

I874. Unciola irrorata, Smith, Rep. U. S. Com. Fish., IS7I-2, p. 567 , pl. 4 , fig. I9.

Bonly depresied; coxal plates very low; eyes nearly round.

First antenlate orer half as long as body, with principal flagellum shorter than peduncle: accessory flagellum shorter than last joint of perluncle. Second antenne shorter than the first, with a thort flageflum and a stong peduncle which is very stout in the male.

First gnathopods much stronger than second and of similar form in the two sexes; hasal joint thick and hollowed out in front; carpus short; propolus very large and oval, with convex 
palm provided with many spines and finely serrated and marked off from the short posterior margin by a stout triangular process; armed apically with a spine; dactyl strong and curved. Second gnathopods slender; carpus triangular and as wide as, but shorter than, propodus, and abundantly provided with setre; propodus oblong, tapering very slightly to distal end, also provided with dense setæ on the margins, palm short, transverse, infero-posterior angle of propodus slightly produced; dactyl very small. Last pair of pereiopods much longer than others, with a long slender dactyl.

Third abdominal segment with postero-lateral angle produced into a slender curved point above which is a prominent sinus.

First uropods with peduncle having an upturned spiniform projection beneath the rami which are one-half as long as peduncle : second pair with no spiniform, projection ; last pair with a single ramus not half as long as peduncle but with peduncle produced into a lobe as large as ramus and lying internal to the ramus. Telson rounded, slightly longer than broad, not extending back quite as far as terminal uropods.

In life the body is mottled bright crimson, head with a broad median band of crimson which divides in front. The first thoracic segment is more highly colored than the others; a row of small crimson spots along either side of the mid-dorsal line; bases of both pairs of antennæ crowned with orange; flagellum with a double row of crimson spots, a pair to each segment, propodus of first gnathopods with crimson blotches.

Length $15 \mathrm{~mm}$.

Distribution: Great Egg Harbor, New Jersey; from Connecticut to the Bay of Fundy (Snith); Nova Scotia; Labrador; Greenland; Spitzbergen; Norway; off New London, Connecticut, taken at 8 fathoms on sandy bottom, July I7, I874; off Saybrook; Fishers Island Sound; north of Fishers Island; $3^{\mathrm{T} / 2}$ to 5 fathoms, Aug. IO, 1874 .

The species ranges in depth from low-water mark to 500 fathoms. It is an exceedingly abundant species, occurring more abundantly on muddy or sandy bottoms.

According to Smith (Trans. Conn. Acad., vol. 4, p. 282) these animals do not construct tubes for themselves but are often found in the tubes of other Amphipoda and Annelida. 


\section{Siphonœcetes Kröyer.}

lindy sknder and narrow, abdomen very small. Coxal plates very small.

- Intculue densely setose and unequal; first pair slender and with un accessory flagellum; principal flagellum well developed. Sccond pair much longer than first, subpediform, with short flagellum armed apically with unguiform spines.

Mandibular palp small, uniarticulate.

Ginath pods unequal, the second pair being considerably stronger than the first pair and distinctly subchelate. Anterior pairs of perciopods with basal joint and merus much expanded; thirel and fourth pereiopods comparatively small, with dactyl inverted; last pair considerably more elongated and with basal joint lamellarly expanded and fringed on both sides with ciliated setre.

First and second uropods biramous, with outer ramus the larger and spinulous externally. Last pair with peduncle lamimarly expanded; single ramus small, simple, setiferous.

Telion imperfectly defined from last segment, smooth above and broadly rounded at tip.

\section{Siphonœeetes smithianus Rathbun.}

I874. Siphonacetes cuspidatus, Smith, Rep. U. S. Com. Fish., $187 \mathrm{I}-2$, p. 566.

1un5. Siphonuccetes smithiumus, Rathbun, Occas. Papers, Boston Soc. Nat. Hist., vol. 7, p. 74.

Head produced into a long, slender, acute rostrum, interantennal lobes long. projecting in a rounded form at the end and somewhat constricted at the base. Eyes situated on interantennal lobes.

First antenne of female extending as far as penultimate joint of peduncle of second antennx; first joint of peduncle stonter than succeeding ones, but subequal in length to each of them; flacellum of about four joints and one-half as long as peluncle. Second antenne two-thirds as long as body; peduncle stout, third joint as long as first joint of peduncle of first antennæe, fonth joint longer than fifth which in turn is nearly one-half longer than the third; flagellum slightly longer than third joint, 
composed of only two joints of which the terminal one is minute. In the male the second antennæ are a little longer than the body and stouter than in the female.

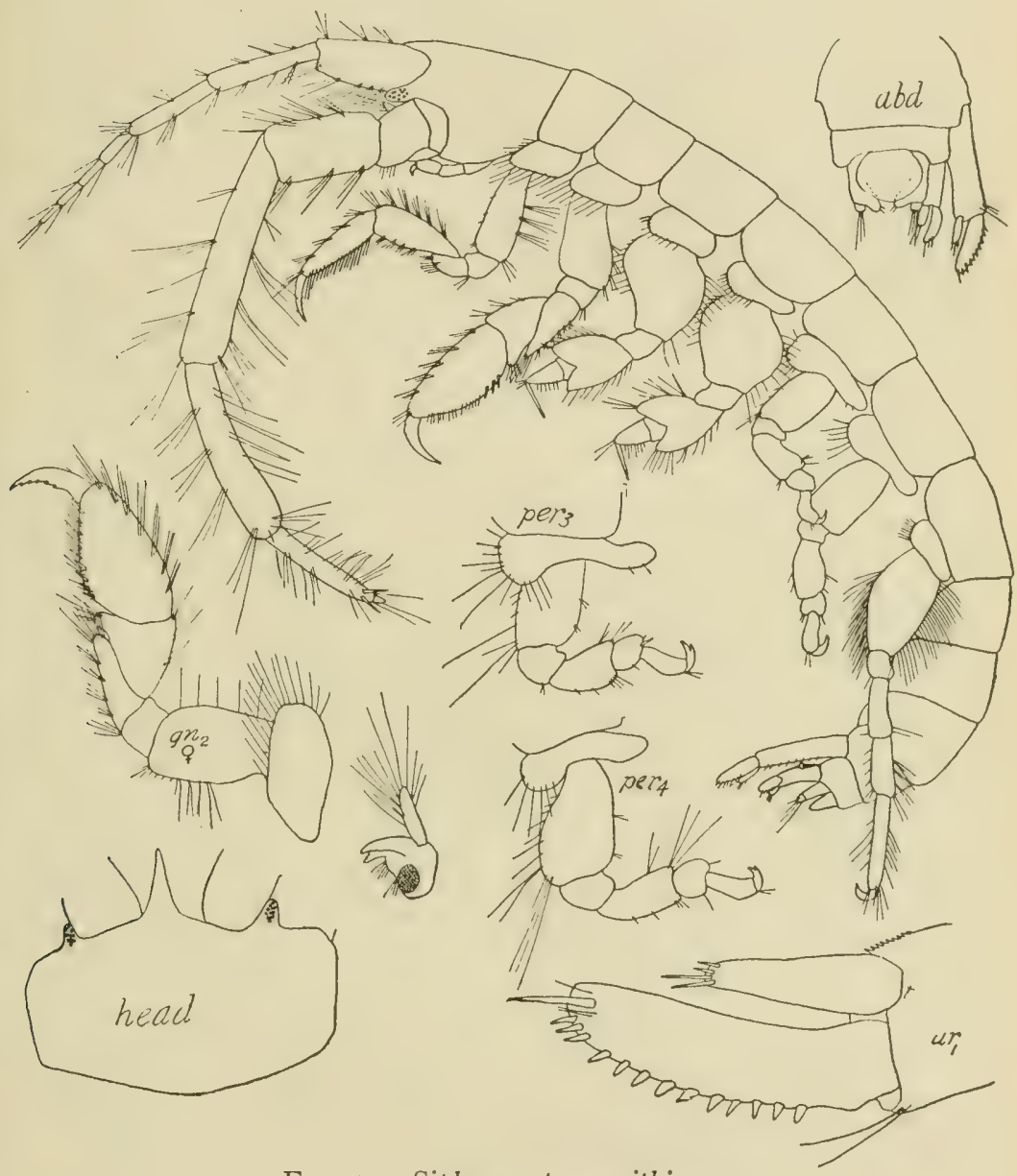

FIG. 5I. Siphonocetes smithianus.

Coxal plates low and not contiguous, with setæ on ventral and anterior margins.

First gnathopods in female with carpus as long as, but broader than, propodus, with slightly convex front margin, which bears six fascicles of setæ; propodus tapering, simple, hind margin 
with abmulant stout setax: dactyl with several serrations near Lip on inner matrin. Scombl gnathopods with basal joint very - font : merus chengated on prosterior margin and terminating in a

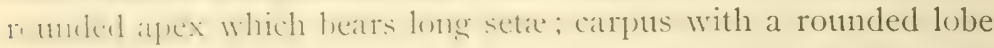
luhind: propulus oblones oval, twiee as long as wide, with mumerons fascicles of setae un front margin, palm long, armed with selat and four spines near the poorly defined prehensile angle: latet with inner margin serrated. First two pairs of pereinpols with batal juints greatly expanded and front and hind matrens strongly convex; merns subcordate in form, with front and hind matrins setose; carpus very shert; propodus tapering, abunt twice as long as wide; dactyl straight, slender, and nearly at long ats the two preceling joints together. Third and fourth ferejoule with hasal joints stout lut not greatly expanded; carfus as houd as lomg; propolus somewhat curved backward; liatil stont and strongly curved. Iast pair elongated, with wat hanal joint prosided on front and hind margins with abundant long setre.

lirst pair of uropods extending heyond the others; peduncle cylindrical and twice as long as outer ramus which is much latrece than inner: distal end of pertuncle internally finely serrated for a short distance; outer ramus with stout spines on wnter matron and a longe one apically. Second pair with outer ramus b nger than inner but not as long as peduncle. Terminal uropods with a single ramus less than one-half as long as freduncte which is expamber to a rounded lobe distally and melially which bears several sete aprically: ramus as broad as lone and with sereral long sute at the rounded tip. Telson broader than long, transversely elliptical.

Length $6 \mathrm{~mm}$.

1)istribution : in deep water oft Vineyard Sound and Buzzards Bay; Long Island Sound.

The species inhabits tulues constructed of grains of sand, usually on bottoms of fine compact mud and sand.

\section{Corophium Latreille.}

lindy comparatively stout and much depressed, with extremely -mall cosal plates : first pair conically produced and tipped by a 
number of strong ciliated setæ. Posterior segments of abdomen flattened and sometimes fused.

Antennæ unequal; first pair slender, without accessory flagellum but with principal one multiarticulate. Second antennæ strong, pediform, generally much stronger in male than female; fourth joint of peduncle large and produced distally to a spiniform process; flagellum short, triarticulate, terminating in several small hooks.

Mandibles with palp small and narrow, composed of only two joints. First maxilla with inner plate obsolete. Second maxillæe with outer lobe larger than inner. Maxillipeds with inner plates narrowly produced; outer plates long and narrow; palp slender, with fourth joint short and setose at tip.

First gnathopods slender with ischium forming below a rounded, densely setose expansion, carpus much elengated and densely setose behind, propodus narrow, with short palm. Second gnathopods somewhat stronger than first; merus forming a broad lamellar expansion which is firmly connected with posterior margin of carpts, and edged with a double row of extremely elongated and finely ciliated setre; propodus sublinear, without distinct palm. First two pairs of pereiopods with basal joint large and broad and merus more or less expanded. The two succeeding pairs comparatively stout and of same structure, both having merus obliquely expanded in front and carpus armed with two oblique rows of strong spines. Last pair of pereiopods elongated and slender with basal joint expanded and densely fringed with long ciliated setæe on both margins.

First and second uropods with short rami; last pair with peduncle scarcely expanded, and single ramus lamellar and setose. Telson small, entire.

\section{Corophium cylindricum (Say).}

I8I8. Podocerus cylindricus, Say; Jour. Acad. Nat. Scr. Phila., vol. I, pt. 2, p. 387 .

I874. Corophium cylindricum, Smith, Rep. U. S. Com. Fish., I87I-2, p. 566.

Body broad and much depressed, with very small coxal plates which are discontinuous. Fourth, fifth, and sixth abdominal segments fused. 


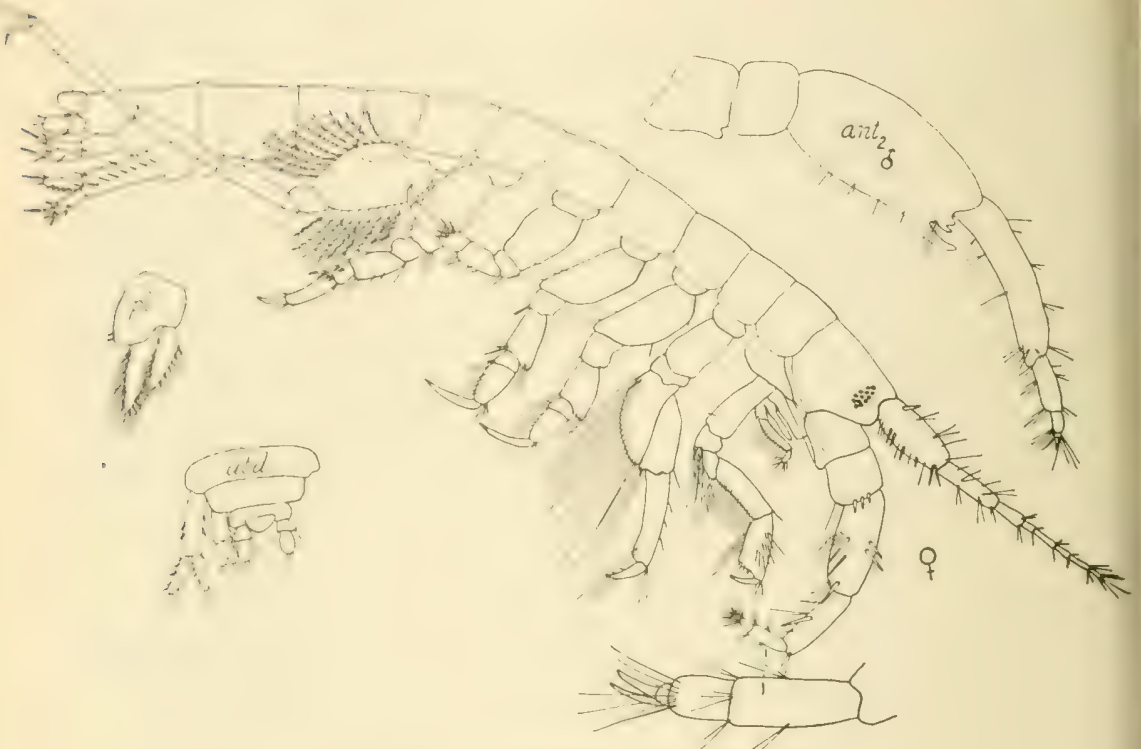

FIG. 52. Corophium cylindricum.

Intennie stout in female, first pair nearly as long as second fair, less than one-third as long as body. First antennæ with first joint of peduncle very stout and slightly longer than second, providerl with several stout spines on lower margin, third joint onehalf as long as second; flagellum as long as second and third joints of peduncle together, and made up of about six rather long segments. Second antenna very stout, pediform, especially in the male: second and third joints only slightly longer than broad, thirel joint with four stout spines distally, fourth and fifth joints sulderutil in length in the female and each about as long as first two joints together, and provided with a few stout spines. In male the lower margin of penultimate joint is produced distally to form a curved, finger-like process. Flagellum very short and stunt and mate up of three joints terminating in two curved spines.

lirst snathopods with coxal plate produced anteriorly and tipped with three sete; carpus rectangular and slightly longer than fropolus, with hind margin provided with long plumose spines; propodus widening a little distally, subchelate, palm 
slightly oblique. Second gnathopods with simple propodus; posterior margin of merus and carpus provided with very long plumose spines; basal joint exceedingly stout; merus with hind margin strongly convex; carpus short and articulating with front margin of merus; propodus subrectangular and slender; dactyl strong and with denticle on inner margin. First and second pereiopods with very long dactyl and stout propodus; carpus short and merus projecting anteriorly and distally as a moderate lobe. Third and fourth pereiopods short; carpus short and armed distally with stout spines; basal joint of fourth pair with a few setæ on the posterior margin. Fifth pair of pereiopods very long and slender with basal joint oval and with margins setose.

First uropods with rami half as long as peduncle; second pair not projecting as far as first pair, with rami nearly as long as peduncle and with apices rounded. Terminal pair, uniramous, peduncle very short and ramus broadly ovate, extending about as far posteriorly as second pair. Telson very short and thick, triangular, entire.

The body is marked with purplish brown pigment cells and the posterior margin of each segment bears a dark transverse band. The anterior part of the head is dark.

Length $3 \mathrm{~mm}$.

Distribution: New Jersey to Vineyard Sound. Noank Harbor, taken at the surface in the evening, also found on piles and among sponges growing on piles; Noank, Long Island Sound, Sea Flower Reef, New Haven, Connecticut.

The species lives in soft tubes although it is often found free. The tubes are particularly common in eel-grass near the roots. It is very common at all depths to 30 fathoms. In dredging, according to the Woods Hole Survey it is rarely found on muddy bottoms.

\section{CHELURIDA.}

Fourth to sixth abdominal segments coalesced. Coxal plates small.

Second antennæ with blade-like flagellum.

Pleopods with peduncle produced on inner side.

Second and third uropods abnormal. 


\section{Chelura terebrans Philippi.}

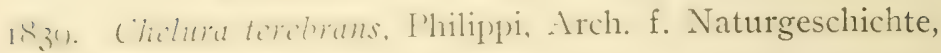
vol. 5 , p. 120, pl. 3, fig. 5 .

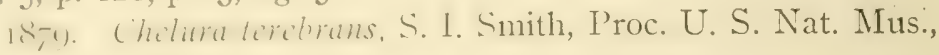
vol. 2, p. 232 .

I894. Chelura terebrans, G. O. Sars, Crust. Norway, vol. I, p. 627, pl. 225 .

This species of word-boring Imphipod is not widely distributed wn the Mlantic coast of North America, having been repurted only irone lloods I Iole and Provincetown, Massachusetts. It excur along the cuast of Europe from Norway to the Mediterranean and also at Bermuda.

It is readily distinguished from all other crustaceans by the structure of the uropols; the first pair lie under the aldomen and hate a long freduncle and two short rami. The second pair have the dirsal erlace of the peduncle expanded into a thin, broad, wal plate projecting beyond the two small rami which are attahed in an enargination of the lower margin. The last pair have very stumt hut short peduncles to each of which is attached a single very long, strong ramus which is much longer in the males than females.

Length $6 \mathrm{~mm}$.

\section{CAPRELLIDEA.}

Ilead fuiced with first thoracic segment, first gnathopods situated close to mouth parts; horly slender and filiform; maxillipeds with well (leveloped palp, one to four-jointed: coxal plates wanting: gills present ustally only on two segments; anterior pereioporls rudimentary or wanting; abdominal appendages lacking or rudimentary. Hepato-pancreatic tubes, two; rectal gland lacking; heart with three pairs of ostia.

\section{Eginella Boeck.}

lionly slemler, sometimes smonth, sometimes coarsely spinous.

Antemite blender and clongated; second antenna with short, biarticulate flagellum.

Mandibles with moliar tuliercles well marked and palps moderatcly develuperl and triarticulate. Maxilliperls with outer plates strongly spinous on inner margin. 
Gnathopods . very unequally developed, the first pair being small. Second pair much elongated with propodus exceedingly large and with palm divided into acute lappets. First two pairs of pereiopods wholly absent. Three posterior pairs strongly developed and similar, with propodus large and expanded at base. Gills present on only the third and fourth thoracic segments.

Abdomen with two pairs of appendages in both sexes.

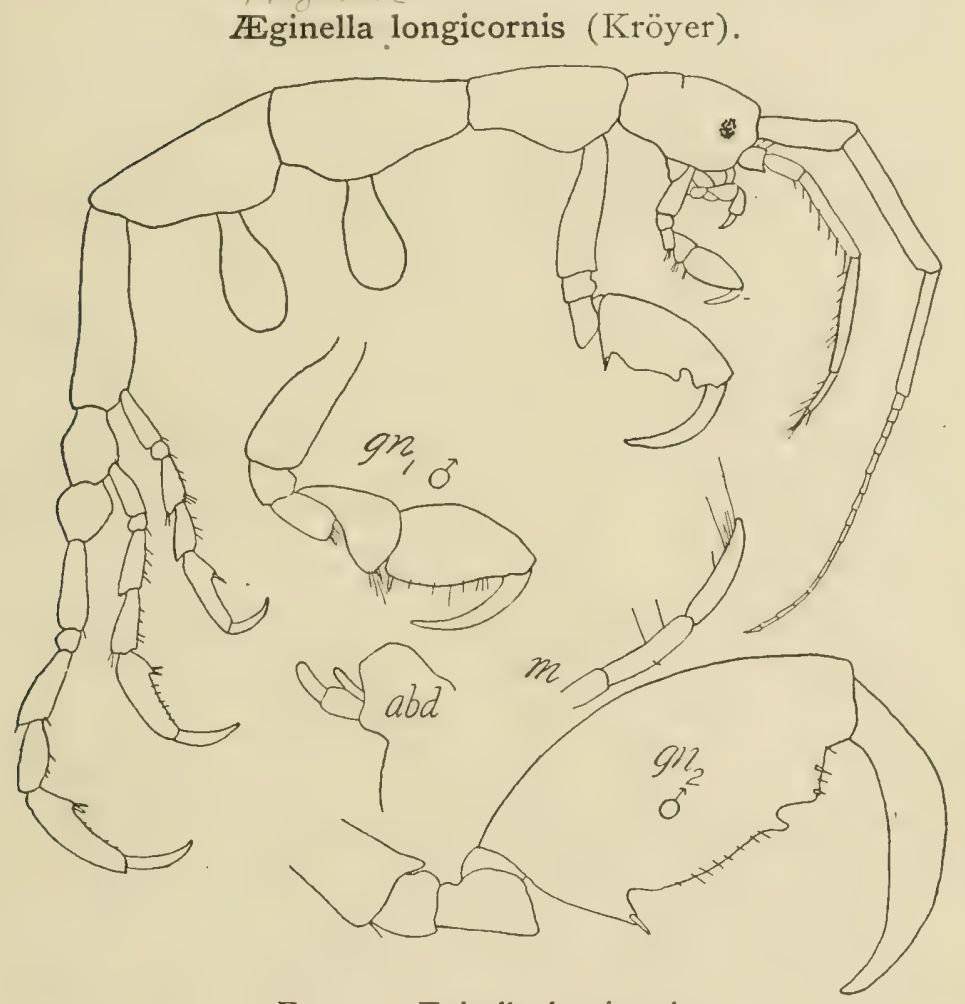

FIG. 53. EEginella longicornis.

1842-3. Egina longicomis Kröyer, Naturhist. Tidsskrift, I Räkkes, 4 Bind.

Body slender, smooth or spiniferous, head often furnished with a pair of dorsal spines.

Eyes small. 


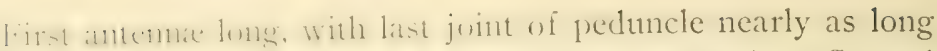
as proving wne; flagellum shorter than peduncle. Second anemue whanling hut litte leyond pentitimate joint of peduncle wi lint: linet joint wi peduncle longer than the preceding one; Alugellum liarticulate and surter than last joint of peduncle.

fir-1 anathofols with propolus having palm nearly straight and entemling (1) proximal end of joint where it is defined by a stut prehensile spince. second gnathopods with basal joint nstrilly slishtly dentate in front and produced below into an ante lefe: ischimm and merus each with an acute inferior furcess : propulus with a triangular tooth at upper end of palm and a narow teoth below the middle separated from a triangular eminence below by a narrow sinus.

Thirl, fourth, and lifth pereiopods increasing in size posteriorly.

Gills oval, elongated.

Mulnmen with (wo pairs of appendages in both sexes; the first pair of which are biarticulate.

Length 16 nim.

Distribution: Siberia; Greenland; Labrador; Eastport, Mane: Narraganstt Har: Nouds Hole, Massachusetts; Long Island Sound; off Sea Flower Reef.

The develoment of spines on the body is very variable; they may be reduced to small tubercles or entirely absent.

\section{Caprella Lamarck.}

Body more or less slender, being as a rule much more elongated in the male than female.

lirs antemna clongated. Second antenna generally densely setose below, flagellum biarticulate.

Mandibles without palp. Maxillipeds with outer plate scarcely larger than inner one; palp very strong.

firir-1 gnathepuls of usual structure. Second pair strongly

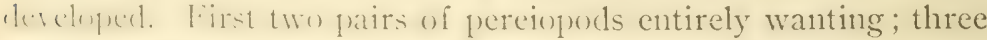
foreriot pairs of sinilar form, generally strongly built and subdhelete. Aills prenent only on the third and fourth thoracic segments.

Vhinmen in iemale without distinctly defined appendages; in male with a pair of biarticulate limbs in front. 


\section{Caprella linearis (Linnæus).}

Cancer linearis, Linnæus, Syst. Natur., p. I056.

Body slender, although the third and fourth thoracic segments of female which bear marsupial plates are rather broad,

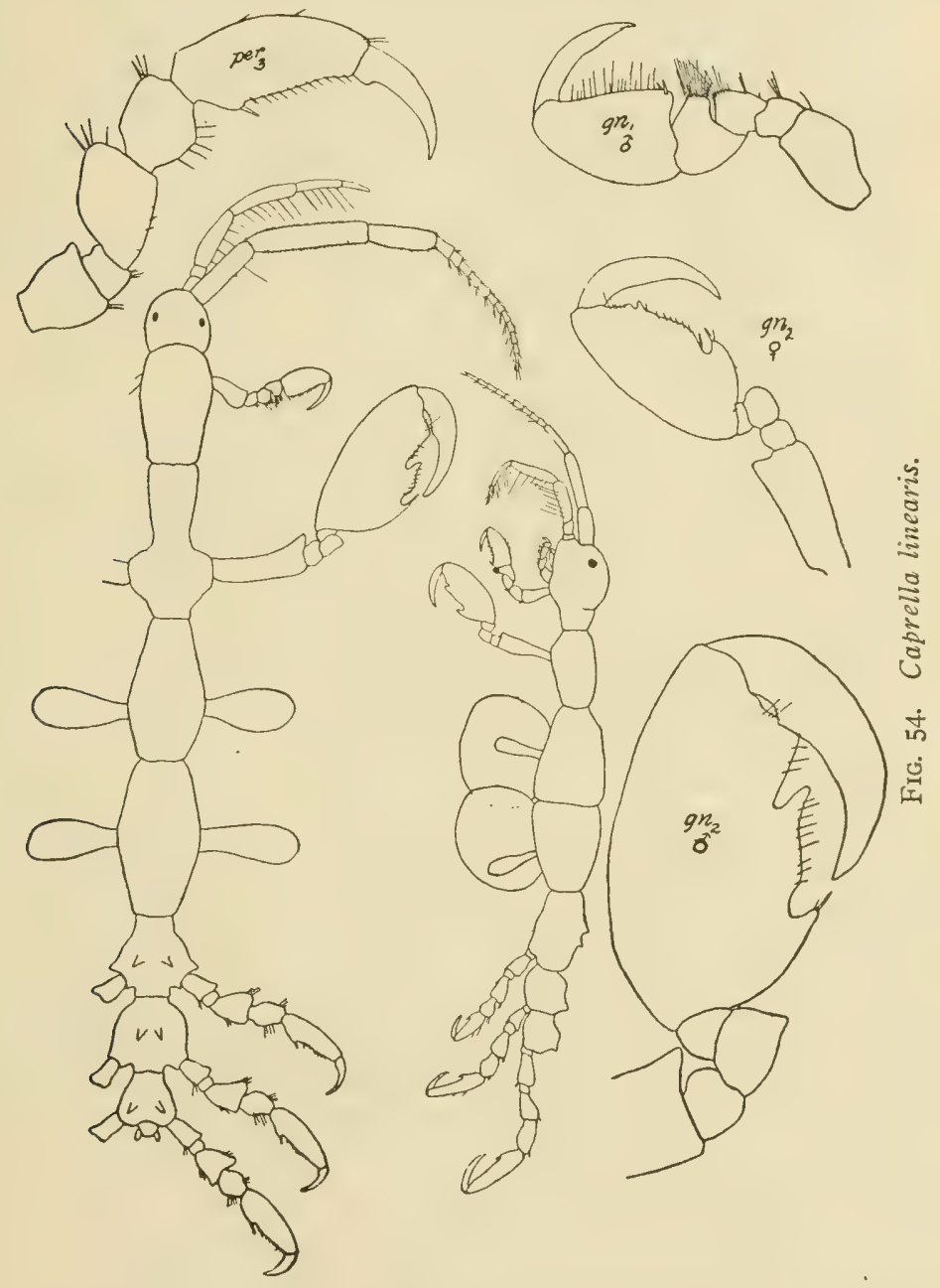

smooth except for a few slender tubercles on the three posterior segments. Body of adult male much more slender than female, 
lir-t irec thuracic segment equaling in length the three succeeding segments combined.

\section{Eyes small, round.}

liris antenne in female stout, half as long as body; first and thirel joints of peduncle suberpual, second joint longer; flagellum neatrly as long as peduncle and composed of about a dozen joints. In male joints of peduncle expanded and finely ciliated on edges. second antenne longer than peduncle of first ; flagellum composed of two joints and as long as last joint of peduncle.

First gnathopods with carpus short and forming a rounded lobe beitring scte posteriorly; propodus twice as long as carpus, triangular, with palm occupying whole posterior margin and defined proxinally by a projecting angle armed with a spine. second gnathopods in female attached in front of middle of segment; hasil joint with antero-distal angle produced to form a triangular process; propodus oval, palm defined proximally by a prominent projection with spine and bearing a small triangular lobe near distal end. In male second gnathopods with basal joint longer than propodus and attached near posterior end of correspunding segment; propodus long and slender, oblong in form, palm irregularly indented, having at the middle an acute furojection, and in front of projecting angular lobe, the two being separated by a deep sinus.

Gills large and oval.

I'ereinguls three pairs, stout; with narrow propodus having falm alunt two-thirds as long as posterior margin and defined proximally by a projection bearing a spine.

I.ength if mm. Females always much shorter than males.

I)istribution: European coast south to France; Greenland and Labrador (()rtmann); Casco Bay, Maine; Portsmouth, New Iamphire (Mayer); Grand Manan (Holmes); off Head Harbor to Silem, Missachusetts; Annisquam; off Montauk Point (Holmes); Noank, Connecticut.

\section{Caprella geometrica Say.}

I818. Cuprella gcometrica, Say, Jour. Acad. Nat. Sci. Phila., vol. I, pt. 2 , p. 390 .

Bully robust and devoid of spines and tubercles; head with large triangular process projecting anteriorly. 


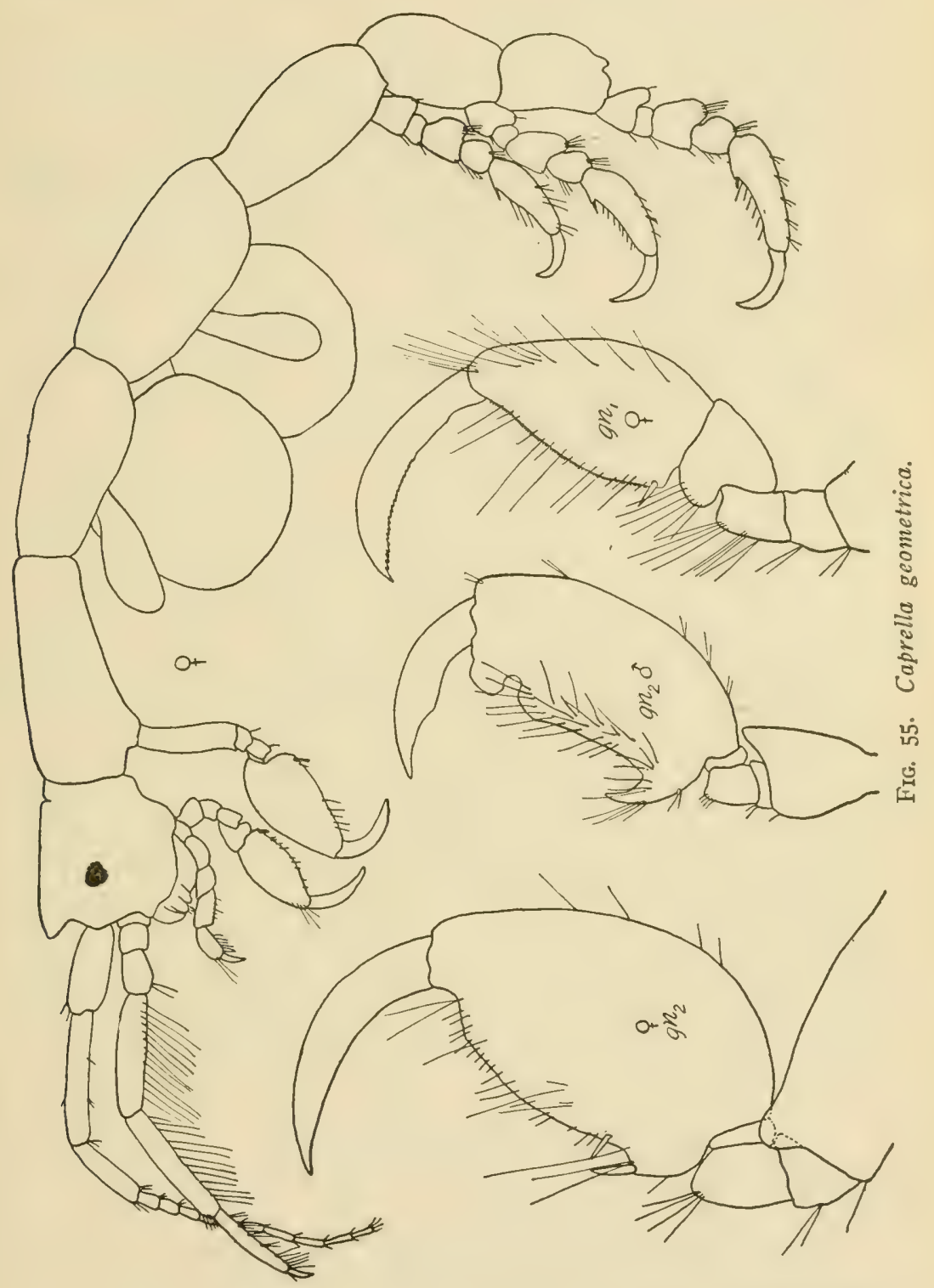

Antennæ stout, first pair with second joint of peduncle the longest, and with flagellum, composed of about a dozen segments and shorter than peduncle. Second antennæ two-thirds as long 
as first with ventral margin of peduncle fringed with long setæ, fifth joint of peduncle the longest; flagellum as long as penultimate joint of fredumcle and composed of two segments.

First gnathopods with very short basal joint; carpus bearing a rounded lobe posteriorly which is provided with group of long sete: propoclus triangular, twice as long as wide, with anterior and fusterior margins slightly convex, palm coincident with fusterior natrin and tinely serrated, proximal angle with stout spine: lactyl longrand stout with concave margin serrated.

second gnathripuds with basal joint shorter than propodus and learing a rounded lobe at antero-distal angle; carpus very short; fropolus oval, tapering somewhat distally; setose palm convex and nearly as long as posterior margin and demarcated by a process and two spines, anterior margin strongly convex, pereinpols stout: carpus as broad as long and one-third as long as propulus which hats a palm nearly as long as front margin, (ienarated from it ly a prominent projection having a spine on its apex; dactyl long and strongly curved.

The color is very variable. Some individuals are nearly colorless; others are uniformly reddish; and others mottled.

Length, of adult male, I $5 \mathrm{~mm}$.

This is one of the commonest species of Amphipoda on the crast uf New England. North of Cape Cod it is more rare, and, accorling to Hhimes, it has not been found at all as far north as Maine: southwards it probably extends beyond Virginia. II ithin the limits of Connecticut it has been obtained at New Haven and Noank; at the latter place in eel-grass and on the piles of a wharf, in sponges, etc. The species has also been reported from the Mediterranean, Belgimm, France, Great Britain, Hong Kong, and Rio Janeiro.

Caprella æquilibra Say.

Isıs. Caprellu cequilibra, Say, Jour. Acad. Nat. Sci. Phila., vol. I, pt. 2, p.

liokly comparatively robust and perfectly smooth above, with anterior part very much elongated. Head without an anteriorly directed spine.

Sccond snathopods of the male with the basal joint very much shorter than the propodus and attached near the posterior 
end of the segment. A ventral spine between the bases of the second gnathopods.

Length of adult male $13 \mathrm{~mm}$.

This species has a remarkably wide distribution. It has been recorded from the British Isles, France, the Mediterranean, Azores, Bermuda, Brazil, Japan, New South Wales, New Zealand, and the whole Atlantic coast of North America. 

PART II

\section{ISOPODA}





\section{PART II. ISOPODA.}

The Isopoda are divided into six suborders by Sars, whose classification of the group is ustually followed and upon whose key the following one is based.

\section{KEY TO THE SUBORDERS OF ISOPODA.}

A. First gnathopods chelate; uropods terminal; pleopods when distinctly developed, exclusively natatory .......TANAIOIDEA p. 193 AA. First gnathopods not chelate.

B. Uropods lateral.

C. Uropods forming together with the terminal segment of the abdomen a caudal fan; pleopods 'for the most part natatory CYMOTHOIDEA p. I97

CC. Uropods valve-like, inflexed, arching over the pleopods which to a great extent are branchial ......IDOTHEOIDEA p.2I4

BB. Uropods terminal.

C. Pleopods exclusively branchial, generally covered by a thin opercular plate (the modified first pair) ....ASELLOIDEA p. 230

CC. Pleopods fitted for air-breathing ......... ONISCOIDEA p. 237

CCC. Pleopods, when present, exclusively branchial in the adult and not covered by an operculium ...... BOPYROIDEA p. 235

\section{EXTERNAL ANATOMY.}

The Isopoda differ most strikingly from the Amphipoda in the general form of the body which is always depressed or, at least, not compressed laterally. The Anthurida are very slender and elongate and represent an extreme condition which is comparable with that of the Caprellidea. With the exception of the Bopyridie, which are parasitic, the Isopoda are all bilaterally symmetrical. In this one aberrant family the males and females are exceedingly different in form, the females being four or five times larger than the males and exhibiting marked degenerative changes while the males are minute and remain permanently attached to the body of the female in the region of the latter's genital openings.

The segmentation of the body is less regular than among the Amphipoda; the head is fused with the first thoracic segment in the Tanaioidea and the segments of the abdomen suffer various 
deyres of reduction. Many of the Spheromide and Oniscoidea such at () misiss asillus and Armudillidium viulgare are capable of rolling the body completely into a ball.

The hand maty be regarded as composed of seven coalesced segments as in the Amphipodia, the segments being indicated by the appendages.

The eres, which are always present in New England species, are pairel; they may be small and simple, or large and compound, made up of many ocelli. In the Tanaidae the eyes are situated on stallis which are never movalble, but in all other families the eyes are sessile.

There are always two pairs of antenne as in the Amphipoda, but their relation to each other is somewhat different; for the first fritr, instead of arising dorsal to the second, arise nearer the miclille line and so may be designated as the inner antenne. In the Uniconilea the first pair are very small and inconspicuous and are never more than three-jointed. Usually besides the three joints of the perluncle there is a multiarticulate flagellum. In the dihtherider the flagellum is uniarticulate, the segments evidently being funcel. In the Tanaidat the Hagellum of the first antenne is rudinnentary or wanting in the females, as is also the case in the female of Cyathura.

The second antentie are nstually composed of a peduncle of five juints and a nutliarticulate Hagellum, but in Erichsoncla the Hacellar joints are all fused to a single elongate tapering joint. The thing llum is rulimentary in both sexes of the Tanaide, and in the genera Edotea and Cyathura.

The muth patris of the [sopoda resemble closely those of the Imphipuda althongh there are a few important distinctive characters, as for instance; in the Isopoda the first maxilla are Eencrally devoid of a palp) while the second pair carry external to the onter plate a lamellar appendage which is to be looked upon as at palp; and the maxillipeds regularly have a single pair of plates homblesens with the inner plates of those of the Amphipolla, and extemal to the proximal seoment there is an epipod or epignath which is entirely lacking in that group.

the manclibles wisually hear a three-jointed palp but in the

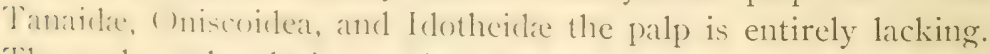
The molar tuluercle is wanting in the Cymothoidae, Limnoriidae, Armadillididx, Oniscidx, and Egidx. 
The first maxille lack a palp in all the Isopoda except the Tanaioidea in which a backwardly directed one is present. The Tanaidæe and Egidæ exhibit a single lobe in the first maxillæ whereas typically the first maxillæ consist of two unequal lobes, the inner of which is the smaller. The second maxillæ are typically tri-lobed at the apex but in the Oniscoidea they are laminar with only a slight indication of division into lobes; in the Egidæ there are only two lobes and in the Tanaida the second maxillæe are quite rudimentary.

The maxillipeds bear a palp of a varying number of joints and have a single expansion corresponding to the inner plates of the Amphipodit. In the Tanaoidea the epipod extends within the branchial cavity beneath the lateral margins of the carapace and serves as a bailer like the scaphognathite of the Decapoda. In the Fgidx the epipod becomes fused with the basal joint.

In the Anthuridæ the mouth parts are suctorial rather than masticatory in function.

The thorax is always distinctly segmented, and in the New England forms, with the exception of the Tanaioidea, is made up of seven free joints. In the single group mentioned the first segment is fused with the head.

The legs are normally fourteen in number, and made up of the same number of joints as in the Amphipoda. The most important distinction from the legs of the latter group is in the coxal plates which are usually not separated from their respective segments and are never as movable as in the Amphipoda. In no case is the first coxal plate separated from its segment. In the Tanaidæ the coxal plates, or epimera, are quite small, while in the Oniscoidea they are greatly expanded.

It is only in the Oniscoidea that the legs are sufficiently similar in structure to warrant the name of the whole group Isopoda. The first pair are frequently quite different from the succeeding ones. In the Tanaidre the first pair are chelate, and in many of the other groups the first one or two pairs are subchelate.

In the females oöstegites are attached to four pairs of appendages, generally to the first four but occasionally to appendages two to five inclusive. The Cymothoidæe are exceptions, bearing five pairs of oöstegites on the first five pairs of appendages and 
alun two faits of small supplententary ones on the succeeding somment In the gentus Tumais the coistegites are limited to a single pair borne on the fifth segment.

The abdementemint typically of six segments, as is clearly indleated ly the appendiges: the five anterior segments are thom, the teminal whe is latre. The ablominal segments suffer varion- reflutions in number ly fusion with each other. Thus

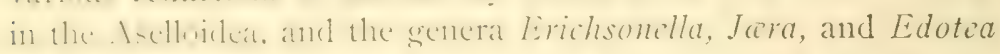
all the sewnente are minted to a single large plate; in the Sparomidie and fentes of (juthura the five anterior abdominal segments are fused together; in ldothea the abdomen consists of tw. short segments atnd a latre terminal one; in Chiridotea, of thre short one's and a large terminal one; and in Tanais, of four short ones and a large terminal one.

The alpemelige of the ablomen amsist of pleopods and uro-

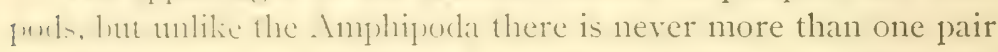
ci umpuls, which are teminal in position in the Tanaioidea, the (niscriblea, and . lselloiklea, and lateral in the Cymothoidea and

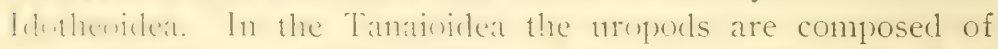
many junts hut in the ()niscoidea and Aselloidea the rami are not juinted hut styliform. In the Cymothoidea the uropods are more or lest lamellar in form, consisting of a peduncle and two oval rami, and with the terminal secment of the abdomen, with which they articulate laterally, form a lind of candal fan somewhat like that of the Macrura. In the Anthuride the outer ramus ocoupes a superior position arching over the telson, and in the Sharminte the inner ranuts is fixed and only the onter one is muvilile. In the lowthericlea the uropuls close over the pleopods, meding ventrally in the miklle line like double doors. These valves articulitte with the terminal segment of the abdomen only along the lateral margin.

The plengeds are thetlally present in five pairs and consist of at peluncle and two lamellat rami. They function for swimming and respination: and in the male the inner ramus of the second latir leats at sonder stylet which aids in copulation. In the fimothidea the plersucle are buth natatory and respiratory;

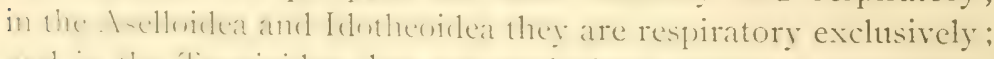

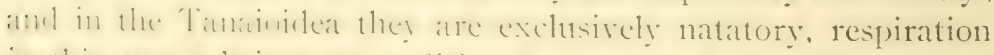
in this swmp lumg acomplished ly means of special chambers 
under the sides of the posterior part of the carapace. In the Oniscoidea air sacs, or tracheæ, adapted for air breathing, are developed in some or all of the pleopods. In Tanais the pleopods are reduced to three pairs; and in the Asellidæ the first pair of pleopods is quite small and the outer rami of the second pair are very large, forming a kind of operculum in the female, and complex copulatory organs in the male. In the Oniscidæ and Armadillididx the first and second pairs of pleopods are modified to form sexual organs in the males, those of the first pair often being coalesced in the Oniscidæ and rudimentary in the females.

\section{INTERNAL ANATOMY.}

The alimentary canal is a straight tube much as in the Amphipoda. A coecal appendage corresponding to the rectal gland is lacking. From the union of the stomach and the intestine there extend posteriorly four hepatic cœca which are more or less coiled.

The heart is an elongated tube sicuated to a great extent in the abdomen except in the Tanaioidea, where it occupies the anterior part of the thorax, and in the Asellidæ, where it is confined to the thorax. The dorsal aorta arises from the anterior end and in the method of branching there is great variation in different species.

The nervous system and reproductive organs in general are similar to those of the Amphipoda.

\section{BIOLOGY.}

Like the Amphipoda this group is for the most part marine, but unlike that group there are some forms among the Oniscoidea which have extended their habitat to land and are fully adapted to a terrestrial form of life by the modification of the pleopods. Within New England there is but a single fresh-water form Ascllus communis - which is widely distributed and very abundant. The terrestrial forms include several of practically worldwide occurrence such as Armadillidium vulgare, Porcellio scaber, Oniscus asellus, Metoponorthus pruinosus.

Of the European forms which are found on the Atlantic coast of North America are Idothea metallica, Cyathura carinata, Eiga psora, Cirolana concharum, Idothea marina, Jcra marina, Leptochelia savignyi, Tanais cavolinii, Linnoria lignorum. 
The iund of the Isopocla consists for the most part of mollusw. anndids. crustacea, and fich which are consumed generally when ckat. Cirolunt concharmm feeds on the blue crab, from a single specinen of which as many as Ios individuals have been talicin. The stomachs of terrestrial forms have been found to contain moss cells and algæ.

Besiles the Bopyrids there are several other forms which are also parasitic. The Cymothoidae and Egida attach themselves to the finc, grills, and mouths of fishes. Egathoa oculata has been taken irom the mouth of a squid and also from a young mullet. The lingridie are all parasitic on Crustacea and attach themselves to the aldomen or within the branchial cavity beneath the carapace.

The sccondary sexual differences which occur among the native Lonodia are less marlied than among the Amphipoda. In the Tamaiclie the legs of the first pair in the males are much more rolust and longer than those of the females but of similar form. In Leptochilia the males have greatly elongated first gnathopods and antenne while the females have these parts much reduced.

The development of several genera, Jora, Ascllus, Ligia, Cymothu, Porcellio, and Amadillidium has heen described fully by Mc.lurrich, Iso5 (Jonrnal Morphology, vol. Ir, pp. 63-I55).

\section{LIST OF SPECIES.}

In the following list of Isopoda, an * before a species indicates that it has not been reported from Connecticut although it has been reported from adjacent regions and may be expected in this state as well : a t indicates that the species occurs in fresh water; and $\mathrm{a} \ddagger$ that the species is terrestrial. ${ }^{1}$

TANAIOIDEA Or CHELIFERA. Tanaidxe

Tomis curolinii Milne-Edwaris. Leptochelia savignyi (Kröyer).

*L. rapax Harger.
Edotea triloba (Say).

E. montosa (Stimpson).

Erichsonclla attemuata (Harger). E. filiformis (Say).

1 Since the manuscript of this naper was completed Professer A. E. Verrill has informed me of two species of Isopoda which have not hitherto been recorded from Connecticut, but which he had collected during the past two ycars at the Thimble Islands. These two species I believe will be figured by Professor Verrill in his forthcoming report on the Higher Crustacea of Connecticut, to be published in this series. The two species are Olenctra presgrustator, parasitic on the mouth and gills of menhaden, and Ione thompsont, parasitic on the gills of Callianassa stimpsoni. 
CYMOTHOIDEA Or FLABELLIFERA.

Anthuridx.

Cyathura carinata (Krŏyer).

Ptilanthura tenuis Harger.

Cirolanidæ.

Cirolana concharum (Stimpson).

Ega psorc Egid

Cymothoidæ.

Egathoa oculata (Say).

Livoneca ovalis (Say).

Limnoriidæ.

Limnoria lignorum (Rathke).

Sphæromidæ.

Spharoma quadridentatum Say. IDOTHEOIDEA Or VALVIFERA. Idotheidæ.

Chiridotea coeca (Say).

C. tuftsii (Stimpson).

*Idothea metallica Bosc.

I. baltica (Pallas).

I. phosphorea Harger.
ASELLOIDEA Or ASELLOTA.

Asellidx.

$\dagger$ Asellus communis Say.

Janiridæ.

Jara marina (Fabricius).

BOPYROIDEA Or EPICARIDEA. Bopyridæ.

* Stegophryxus hyptius Thompson.

* Probopyrus pandalicola (Packard). ONISCOIDEA.

Oniscidxe.

$\ddagger$ Oniscus asellus Linn.

Philoscia vittata Say.

$\$$ Cylisticus convexus (DeGeer).

\pm Porcellio rathkei Brandt.

$\pm P$. spinicornis Say.

$\ddagger$ P. scaber Latreille.

$\$$ Metoponorthus pruinosus (Brandt).

Actoniscus ellipticus Harger.

Armadillididæ.

$\ddagger$ Armadillidium vulgare (Latreille).

Scyphacidæ.

* Scyphacella arenicola Smith.

\section{KEY TO THE GENERA OF ISOPODA.}

A. First pair of legs chelate, uropods terminal.

B. Uropods simple, short, uniramous, pleopods three pairs

Tanais p. I93

BB. Uropods biramous, pleopods five pairs ..... Leptochelia p. I95

AA. First pair of legs not chelate.

B. Uropods lateral.

C. Outer ramus of uropods arching over base of telson.

D. Maxillipeds with uniarticulate palp ......Ptilanthura p. 200

DD. Maxillipeds with biarticulate palp ....... Cyathura p. I98

CC. Outer ramus of uropods not arching over base of telson, and uropods not inflexed ventrally.

D. Abdomen of six segments.

E. Uropods with one ramus rudimentary ...Limnoria p. 2I I

EE. Uropods with both rami well developed.

F. Maxillipeds with palp free and margins of last two joints never furnished with hooks ...Cirolana p. 203

FF. Maxillipeds with palp embracing distal portion of buccal mass.

G. Both pairs of antennæ with peduncle and flagellum well defined ................... Ega p. 205

GG. Antennæ much reduced, without clear distinction between peduncle and flagellum.

H. Head produced posteriorly in three lobes, a larger median one and two small lateral ones ................... Egathoa p. 207

HH. Head not produced posteriorly..Livoneca p. 209

DD. Abdomen of two segments ............ Sphæroma p. 212 CCC. Uropods infiexed ventrally and valve-like. 
D. Sides of head emarginate and produced laterally beyond the eyes, which are dorsal ............ Chiridotea p 2 I5

DD. Sides of head not produced laterally; eyes placed laterally.

E. Flagellum of second antennæ multiarticulate.

Idothea p. 218

EE. Flagellum of second antennx not multiarticulate.

F. Second pair of antennx shorter than first. . Edotea p. 223

FF. Second pair of antennx longer than first

Erichsonella p. 227

BB. Uropods terminal.

C. Pleopods exclusively branchial.

D. Fresh-water. First pleopods in male not coupled with second pair, peduncle short; second pair small and situated below first pair ............... Asellus p. 23 I

DD. Marine. First pleopods in male coupled with second pair, peduncle elongate; second pair large and situated external to first ................... Jæra p. 233

CC. Pleopods fitted for air-breathing.

D. Second antenna long and close together; legs long; uropods produced, reaching beyond terminal segment of abdomen.

E. Flagellum of second antennx of three joints.

F. Epimera of thoracic segments large, with posterior angles acute; abdomen not abruptly narrower than thorax ................................. 238

FF. Epimera of thoracic segments small; abdomen abruptly narrower than thorax.......Philoscia p. 240

EE. Flagellum of second antennx of two joints.

F. Abdomen not abruptly narrower than thorax; epimera of abdominal segments large.

G. Body very convex, capable of rolling up like a ball; joints of flagellum of second antennæ subequal ............................ GG. Body more depressed, scarcely contractile; first joint of flagellum of second antenna longer than second .............Porcellio p. 243

FF. Abdomen abruptly narrower than thorax; epimera of abdominal segments small. Metoponorthus p. 247

EEE. Flagellum of second antennx of four joints.

Actoniscus p. 249

DD. Second antennxe generally short. Contractile into ball; head deeply immersed in first thoracic segment. 


$$
\text { TANAIOIDEA OR CHELIFERA. }
$$

Body nearly cylindrical; head fused with first segment of thorax, forming together a kind of carapace, which contains a small branchial cavity on each side. Coxal plates inconspicuous. Abdomen usually of six segments the last one of which is much the longest.

Second antennæe smaller than first pair and originating directly ventral to the latter.

Mandibles with or without palp. First maxillæ with a reflexed, setose palp. Second maxillee very small. Maxillipeds coalesced at the base and each having an epignath projecting within the branchial cavity.

First pair of legs very strong, curving anteriorly, with cheliform propodus. Second pair sometimes unlike the succeeding ones which are simple and ambulatory.

Pleopods, when present, comparatively small and natatory, with lamelliform rami. Uropods terminal, consisting of a short peduncle and one or two terminal filaments.

\section{TANAIDAE.}

Body scarcely attenuated behind. First antennæe without accessory flagellum; flagellum usually rudimentary in female, multiarticulate in male. Second antennie with rudimentary flagellum.

Mandibles without palp. First maxille with only a single masticatory lobe. Second maxille represented by minute rudimentary lobes. Maxillipeds with narrow, falciform epignath.

Second pair of legs not differing essentially from the following pairs.

Pleopods with uniarticulate rami. Uropods simple or furnished with two short filaments.

\section{Tanais cavolinii Milne-Edwards.}

I880. Tanais rittatus, Harger, Rept. U. S. Fish. Com. for I878, p. 418, pl. I3, figs. 81, 82 .

I899. Tanais tomontosus, G. O. Sars, Crust. Norway, vol. 2, p. I2, pl. 5 . 


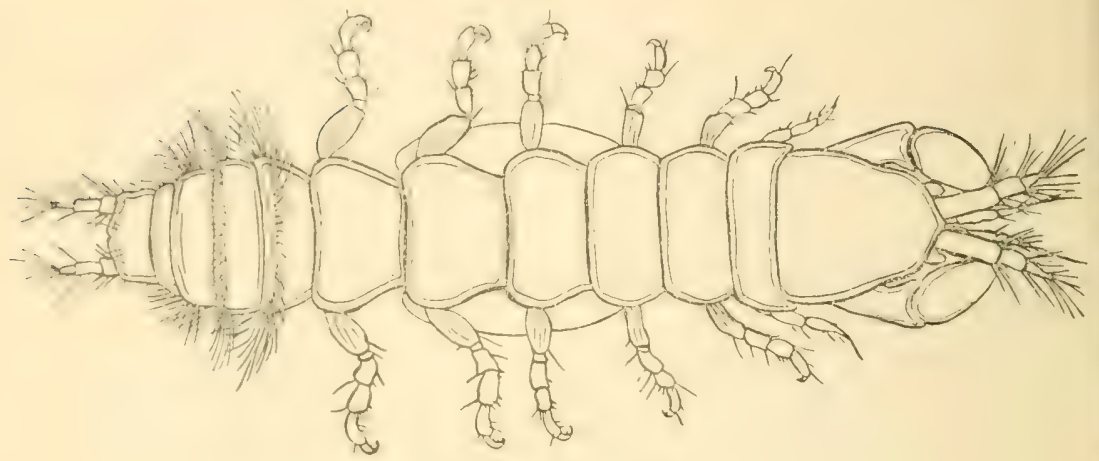

Frg. 56. Tanais cavolinii.

Ino5. Tumis curolinii, Richardson, Bull. U. S. Nat. Mus., No. 54 , p. 8 .

IBuly dongate. between four and five times as long as wide, and constricted at the articulations of the thoracic segments. Hean inser with the first sergment of the thorax, about as long as wile at the wiklest proint, becoming gradually narrower toward the anterior end, anterior marsin triangularly produced with a very ohtuse aljex. Eyes, small, compound, situated on short peduncles at the antero-lateral angles of the head.

Intenne short, the first pair which is the longer, is subequal in length to the head. First pair with first joint two-thirds as long at head : second joint half as long as first ; third joint scarcely as long ats the second: terminal joint minute. Second antennæe shorter than first pair and more slender; first joint not quite as long as the third: fourth joint longer than second and about one-half at long as third; flagellum rudimentary, uniarticulate.

Manclibles without palp). First maxilla with a single plate. Maxillipers with palp of four joints and well developed epignath.

Scomel and thircl somments of thorax subequal in length and shorter than the strecerling ones. First pair of legs cheliform, very litrec, with propodus longer than carpus. Second pair with an especially long dacty, much longer and more slender than the succeeding ones which are all ambulatory.

Vhimencemposed of five serments, of which the first three are sulceptul in width to those of the thorax but somewhat s.r.rter, and the first is slightly longer than the two succeeding 
binly wi nearly miform width throughout and not constricted at the articulations: head longer than wide, anterior portion natroner that fonterior: first free thoracic segment the shortest; the two following ane suluegual hut not as long as the two succulling sements, the latis is shorter than the third. Abdomen anpund of six sennents of which the five anterior ones are sulecputal and somer:hat hroader than the thorax; last segment triangular, with rounded apex.

Eyes large, compound, supported on peduncles.

first antenna in female shorter than head, composed of three sewnents of which the first is longer than the second and third lesecther, and the third is slightly longer than the second. In the mile the lirst antemue are abont two-thirds the length of the howly and are compored of about eleren joints of which the first is one-third at long as the whole appentage and curved somewhat rentrally: Second antenne in both sexes short, not reachifg ats far as apex of first joint of first pair, slender, curved downwards, terminated by a tuft of setæe.

lirst prair of lens in male much larger and more elongated than in female; carpus elongate and cylindrical, extending about one hale it: leneth beyond the head; propedus robust and with a strong curved digital process with two teeth, near the second onc of which ire two stont sete; dactyl curved and provided on inner nuagin with abont seren short sete originating at the bares of at many sermations. In the female, the first pair of legs

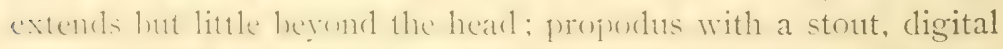
prowes which is hromlly notched near the base and is elevated intw a lighty stmated lobe and bears at its apex a short, stout, terminal tooth.

Scomkl pair of lews. like all the following, ambulatory ; second

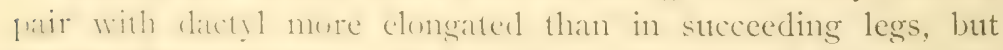
shoter than propulus. Thirel and fourth pairs of legs shorter

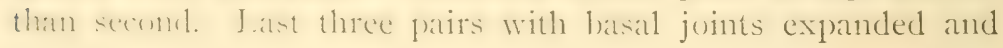
dactyls short.

Uropods consisting of a robust peduncle and two rami, of whith the onter one is rery smatl and miarticulate, and the inner ane is siv-juinted, tapering from the base, with the segments wi equat lemoth and provided with sete near their distal ends.

Pleopods five pairs.

Length $2 \mathrm{~mm}$. 
This species occurs abundantly among eel-grass and algre from the surface to depths of 6 fathoms. It has been reported from England, the Mediterranean, France, the Azores, Madeira also from Provincetown and Woods Hole, Massachusetts; Vineyard Sound; Long Island Sound; Noank, Connecticut; Great Egg Harbor, New Jersey.

It may be distinguished from the other Isopoda of the coast by the following characters; the large and strong chelate first pair of legs, the six-jointed abdomen, and the uropods with a short, one-jointed outer ramus and six-jointed inner one.

\section{Leptochelia rapax Harger.}

1879. Leptochelia rapax, Harger, Proc. U. S. Nat. Mus., vol. 2, p. I63.

I880. Leptochclia rapax, Harger, Rep. U. S. Com. Fish. for I 878, p. 424, pl. 3, figs. 89,90 .

This species has been reported only from Annisquam, Massachusetts, and the Bermudas.

The female resembles quite closely that of $L$. savignyi (Kröyer) but may be distinguished by the fact that the inner ramus of the uropods is five-jointed instead of six-jointed. The males are easily distinguished by the elongate and slender first antemma and the much more slender and elongate carpus and propodus of the first pair of legs; the carpus being about one-half the length of the body and the propodus subequal to it.

Length $4 \mathrm{~mm}$.

The species inhabits tubes.

\section{CYMOTHOIDEA or FLABELLIFERA.}

First thoracic legs not cheliform; uropods lateral and forming with terminal segment of abdomen a caudal fan; pleopods for the most part natatory.

\section{ANTHURIDÆ.}

Body long and slender, subcylindrical. Head comparatively small. Segments of thorax well defined and without distinct coxal plates. Abdomen comparatively short, with the anterior segments sometimes coalesced, telson generally well defined, linguiform. 
linth pairs of antenne, at least in female, short and subequal in length, originating close together.

Mouth parts adapted for piercing and sucking.

Lews wh latsil and irchial joints slender. First pair generally much stronger than the succeeding ones, subchelate; the two stcceeling pairs likewise subchelate but weaker; last four pairs ambulatory.

I'lenume chictly hranchial in character, first pair large and more or less colering the others. Uropods with the outer ramus extending muards, so as to arch over the base of the telson.

\section{Cyathura carinata (Kröyer).}

IŚo. Inthura polita. Ilarger, Rep. U. S. Com. Fish. for I878, p. 398, pl. i i, figs. 68, 69.

IESo. (juthuru curinuta, Norman and Stebbing, Trans. Zool. Soc. London, vol. i2, pt. 4, p. I24.

1005. C Cuthura curinati, Richardson, Bull. U. S. Nat. Mus., No. 54, p. 63.

IBuly more than seren times as long as wide. Head slightly brwiler than lomer and decply excarated on each of the front angles for the bases of the first antennæ.

Jifes small and lateral, distinct, situated on the outer side of the anterior prolongations of the head.

lirst antenne with first and second peduncular joints subequal in length; thirel joint a little shorter than second; flagellum consisting of a single very short joint half as long as the third joint; secomel joint fumished on lateral aspect with a row of setæ. Scombl antennat with first joint short; second joint twice as long as first; third joint half as long as second; fourth joint shorter than thirel; fifth joint as lone as third; flagellum very short, made up of one or two segments tipped with setæ.

Mandilifes vith three-jointed palp). Maxillipeds with palp of two joints.

firmt thracic segment the longest; second segment shorter lut comewhat hroater than the first and subequal in length to the thircl, funth, and fifth secrments; sixth and seventh segments prosre-sicly shorter. Coxal plates long and narrow, extending the whole length of the segments and not separated by distinct sutures. 


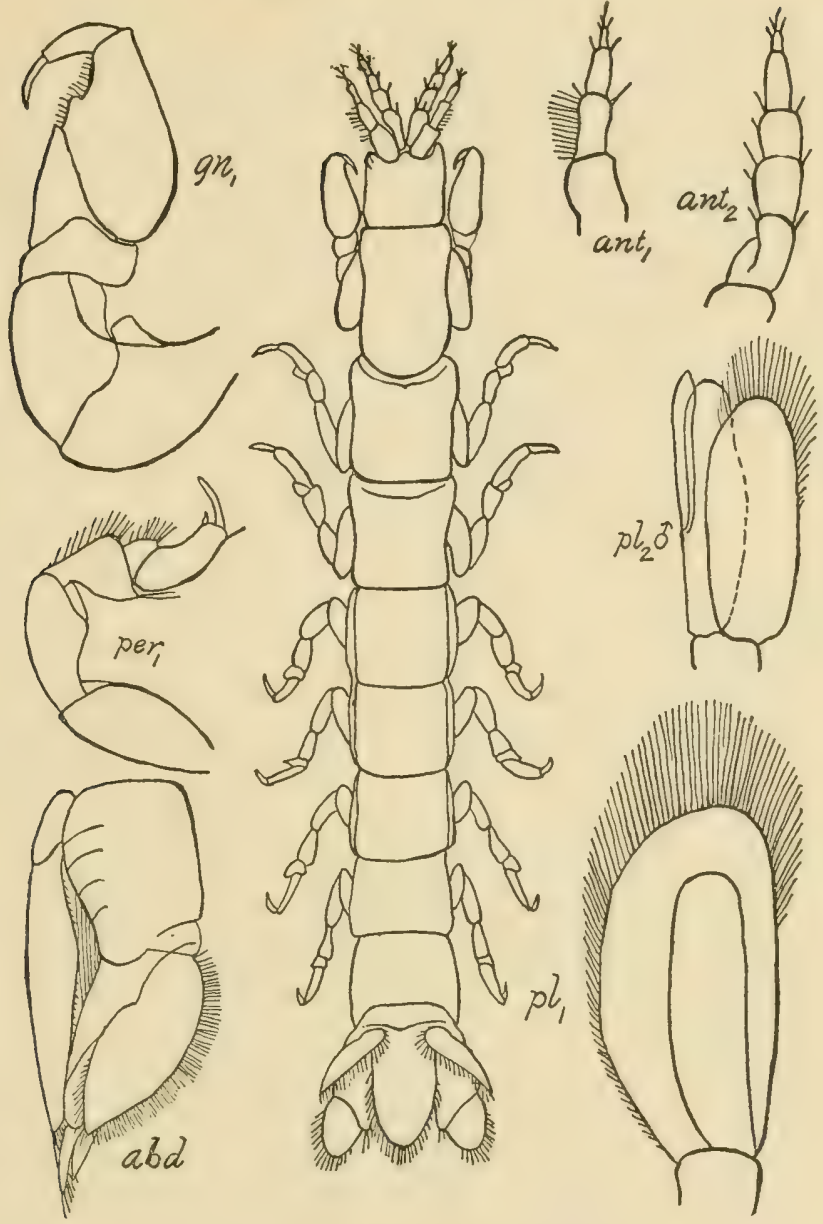

FIG. 58. Cyathura carinata.

First pair of legs robust; basal joint and ischium large and articulated to bring the leg well forward; merus short; carpus triangular and extending along the side of the thickened propodus for half the latter's length; propodus subchelate, ovate, much thickened and provided with a tooth-like process near middle of palm; dactyl short and stout and tipped with a slender, curved spine as long as the joint itself. Second and third legs quite similar to each other, much more slender than first pair; carpus 
very small and triangular. Suceeding legs more slender than acomul and thitel: and with carpus lomger than in preceding legs, ambulatory.

fir-t six alolominal sesments insed to resemble an eighth flumatic segment which is a little longer than the seventh; inlicattind uf the fusion of the first five visible along the sides.

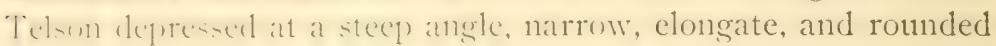
posteriorly, sides nearly parallel, ciliated near the tip.

fir $=1$ jair a f pleapuls composed of a short quadrate peduncle and twe ranni wi which the onter one acts as an operculum, oval in furm with inner margin nearly straight; inner ramus much smaller than onter, slencler, with nearly parallel sides, rounded at tip and not ciliated. Lroporls with elongated peduncle extemling two-thirds the length of the telson and obliquely truncated distally where it articulates whith the short, rounded inner ramus, which in half as long as the peluncle and is setose on its outer ant aproal mareins; outer ranus lying directly on dorsal surface ui felsun, extemoling as far as perluncle, triangular and narrow, with acute apex, setose along its free superior margin.

Length $20 \mathrm{~mm}$.

This species occurs from the surface to depths of $19 \mathrm{I} / 2$ fathums on shelly and mudely lontoms, among eel-grass and alse. Must atumblant hetween tides or just helow low water.

1)intribution: (ireculand: I)ennark; also Gloucester, Massachuscts: I'ineyard Somund; l'rovidence, Rhode Island; off Block Island: Nombl Harlorr. Comnecticut; Long Island Sound; Great Egg Harbor, New Jersey; Norfolk, Virginia.

This speries is distinguisherl by the nearly complete union wi the anterior segments of the aldomen which have together the appearance of an eighth thoracic segment.

\section{Ptilanthura tenuis, Harger.}

I878. Ptilanthura temis, Harger, Amer. Jour. Sci., ser. 3, vol. I 5, p. $37 \mathrm{~S}$.

ISAo. I'tilunthura temuis, Harerer, Rep. U. S. Com. Fish. for $18-8-9$, p. 406, pls. I I and I2, figs. 7I-74.

liody cotremely narrow and elongate. Ilead as broad as 1. ms, with anterior marein produced into a small, median, triangulitr proces. Fyes small, round, distinct, situated within the margin of the head. 

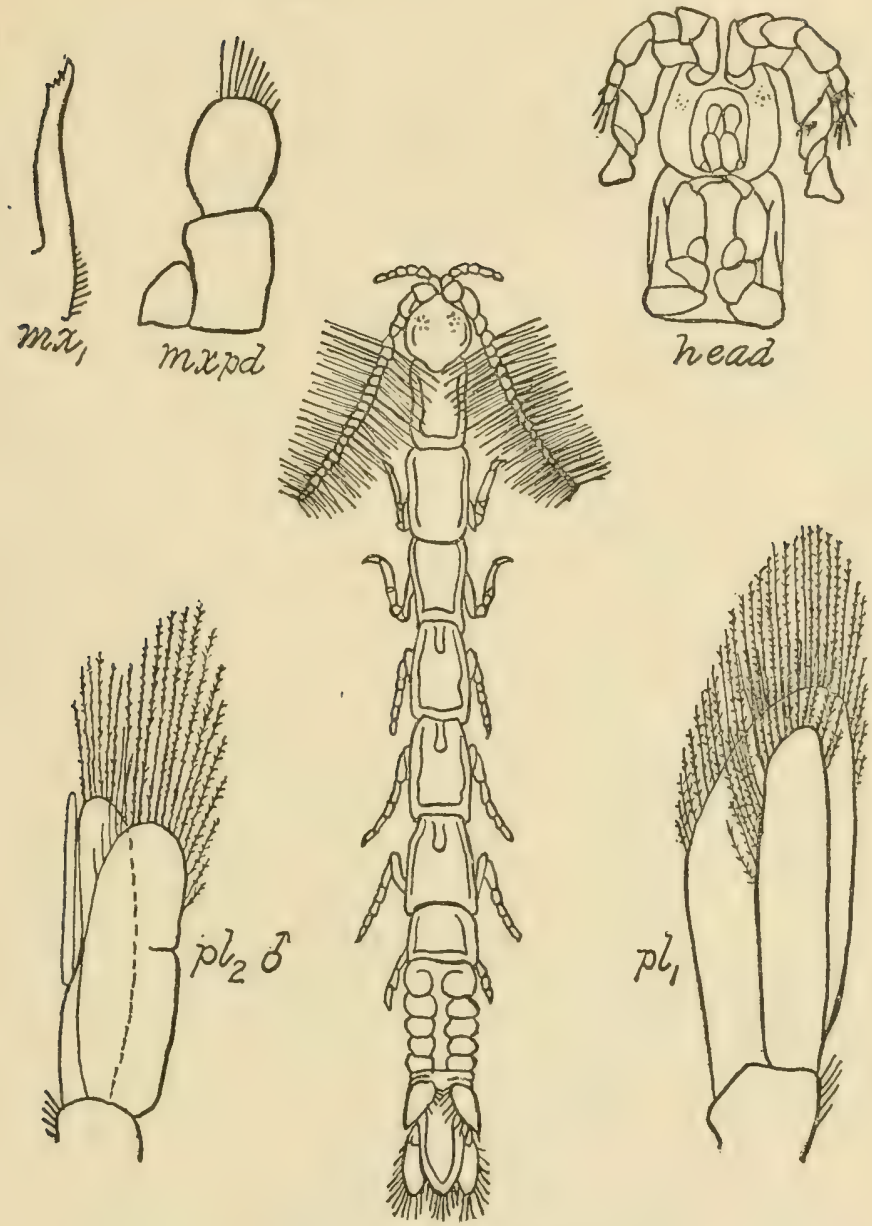

FIG. 59. Ptilanthura tenuis.

First antenna in the female shorter than second pair with a very short flagellum consisting of a small basal segment and a minute terminal one tipped with a few setæ; first joint of peduncle long; second and third subequal and slightly longer than first. In the male first pair of antennæ as long as head and first two segments of thorax together; first segment large but not longer than second, which is also longer than the third; flagellum with first joint one-third as long as second joint of peduncle, 
secoind juint of flagellum twice as long as first and bearing at distal cond a fringe of long slender setre; eighteen to twenty succeeding joints similar to second one.

Mandihles and maxillipels with miarticulate palps.

Iir-t six thracic segments sulecqual in length; seventh segment lut little over half as long as preceding ones but broader hehind than any of them. First pair of legs with carpus nearly

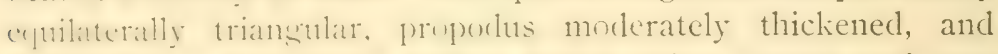
datyl trong and tipped with a strong spine, carpus and prol" hlis with short setie on palmar margins. Succeeding pairs of legs slender and of subequal size.

First live sements of abelomen consolidated along dorsal line lut distinct laterally, subequal in length and each one twice as long as sixth joint. Telson long and narrow with rounded apex. Cropuels with peduncle half as long as telson; inner ramus lamellar, triangular-ovate and extending as far as the telson; whter or stperior ramus narruwly semioxate, extending to end of fulmole, sumewhat triangular in shape, with acute apex.

(olor loromish, more or less mottled above, lighter beneath.

Length II mm.; females about one-third smaller.

This suecies ecurs from the surface to 19 fathoms and has heen ialien from muddy hottoms; in sand, mud, and stones; at low water, in sand.

1)istritution: (irand Manan: Bay of Fundy; Casco Bay, Maine: Vineyard Sound ofi Block Island; off Watch Hill, Rhode I-land: I.nng Island Sound; Noank I Larhor, Connecticut.

The species is rare on this coast.

\section{(IRT)L.INID.E.}

Penly more or less semicylindrical in form. Coxal plates well delined except on the first serment. Ilead not produced medially. Abdomen usually composed of six distinct segments.

Eyes not very large, lateral.

Intemite very mesual in length, the first pair being very small. the seconcl pair long. slencler, and multiarticulate.

Mandibles with cutting part longr, more or less trifid; molar tuluerle chongate, triangular. Maxillipeds well developed with margins of paly furrished with many setre but not with hooks.

I.egs ambulatory, although the first three pairs may also serve for prehension. 
Pleopods well developed, adapted for swimming and respiration. Second pair of pleopods in the male with a stylet inside the inner plate. Uropods lateral, and forming with the well developed terminal segment of the abdomen a caudal fan.

Cirolana concharum (Stimpson).

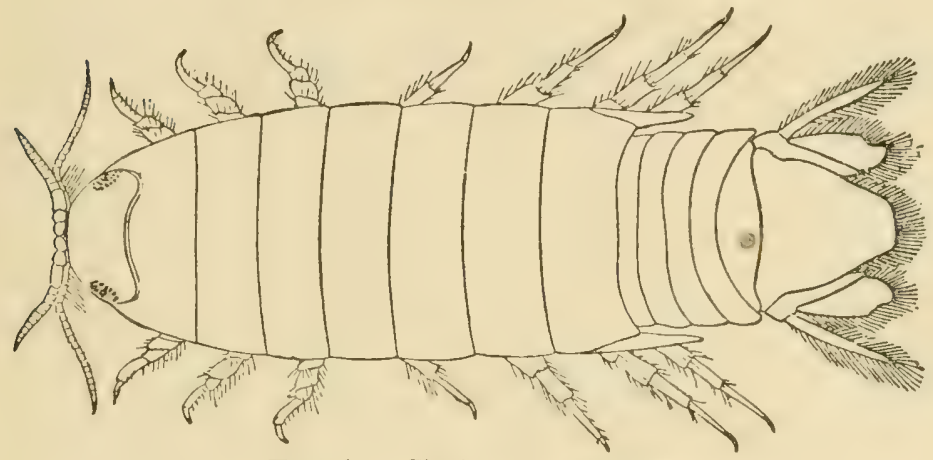

FIG. 6o. Cirolana concharum.

I874. Conilera concharum, Harger, Rep. U. S. Com. Fish. for $187 \mathrm{I}-2$, p. 572 .

I880. Cirolana concharum, Harger, Rep. U. S. Com. Fish. for I878-9, p. 37.8, pls. 9 and Io, figs. 58-63.

Body three times as long as broad. Head quadrate, wider than long, anterior margin rounded, embraced at the sides by first thoracic segment. Eyes small, triangular and with angles rounded.

First antennæ robust, arising immediately beside each other; first and second segments subequal, each one-half as long as third joint; flagellum robust, tapering, consisting of about fifteen joints. Second antennæ longer and more slender than first pair, not in contact with each other at origin; first and second joints short and subequal; third and fourth subequal and each as long as two preceding together; fifth joint a little longer than fourth; flagellum composed of about sixteen joints.

Mandibles robust, palp slender and triarticulate, with the second segment the longest and setose on inner margin beyond the middle, last segment slender and curved. Maxillipeds elongated and almost pediform but flattened; palp five-jointed with last four joints flat, broad, and densely setose. 
connd ant third thoracic segments subequal in length and Shohly swrten than the rest which are also subequal. Coxal flitte dimethety separated from their respective segments on all lut first sement. lirst pair of legs short and stout and well amnel with smines and sete; ischimm nearly triangular with upper marsin much produced distally and setose; carpus short and mall; propulus robust, somewhat curved; dactyl strong and surt. feoml and third pairs resembling first but with longer carpus. fontul gair of leas short like the preceding but recolliling the following except in size, provided abundantly with fa-cicles of scte; propolus straight and much narrower than carpus; fifth and sixth pairs of limbs increasing in size; last pair somewhat smaller.

Melomen slightly narrower than thorax, all six segments distinct: lifth sewment longer dorsally but shorter laterally than the preceling segments. Telson triangular, with setose apex tameatuel and notched at tip). Uropods extending only a little leswat the and of teloun, provided with abundant long setre; rami of equal length, hut outer one only about one-third as wide an inner one which has a notch on onter margin near posterior cond: inner ancle of peduncle produced and extending about twothirds the length of the telson.

l.ength of large specimens $32 \mathrm{~mm}$, average length $22 \mathrm{~mm}$.

This species is found from the surface to depths of 18 fathoms, on muddy and sandy bottoms.

It haw been reported from Charleston, South Carolina; Currituck, North (arolina; Long Island Sound; Block Island; off IFiners Latud: Vincyard Sound; Woods Hole, Massachusetts.

Cocording to the Iroods llole Survey, it is sometimes taken in larec numbers in winter from dead fish; and at WVods Hole hats leen known to block up the cocks of the water supply of the fish hatchery.

\section{IEGID.E.}

Thedy more or less broad and depressed, dorsal surface evenly valulerl and very smootli. Ilead comparatively small, broader than long, front not produced ahove bases of antenna. Eyes, when present, large. 
Antennze directed laterally; first pair shorter than second pair and originating close together; both pairs with distinct multiarticulate flagella.

Mouth parts adapted for piercing and tearing; first maxillæe with only a single lobe which is tipped with short spines. Second maxilla armed with recurved teeth, as is also the terminal joint of palp of maxilliped.

Thoracic segments with coxal plates defined distinctly except on the first. First three legs short and thick, prehensile; last four more slender and ambulatory.

Abdomen composed of six well defined segments, the last one large, scutiform and ciliated on hind margin. Uropods attached laterally beneath the terminal segment. Pleopods adapted for swimming and respiration.

Parasitic, usually attached to the skin of fishes.

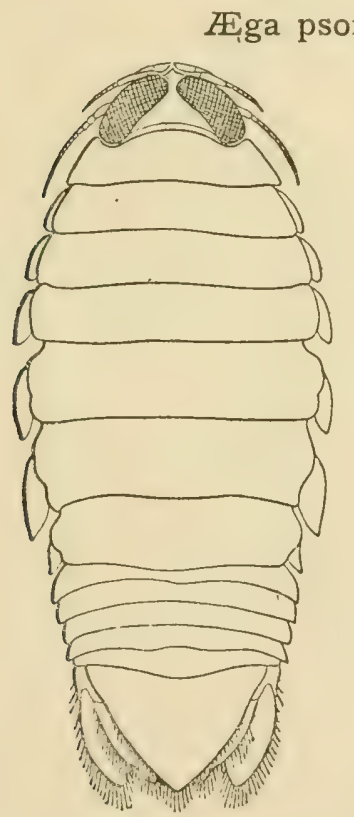

\section{(Linnæus).}

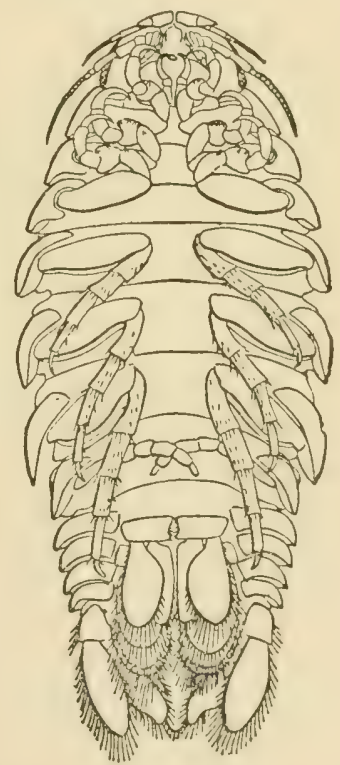

Fig. 6i AEga psora.

I880. EEga psora, Harger, Rep. U. S. Com. Fish. for I878, p. 384 , pl. Io, fig. 64 . 


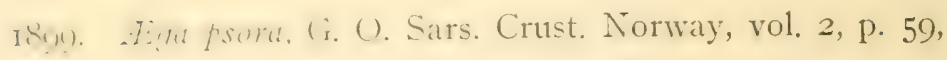
pl. 24 .

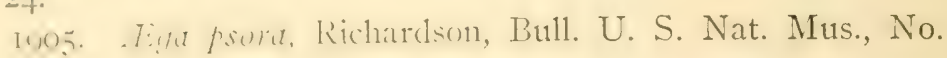
54 , p. 168 .

The following description is abbreviated from Harger's. I have not personally seen this species.

lindy aral. broalest at fourth and fifth thoracic segments where the hradth is alumt half the length; dorsal surface modcratcly convex and smooth except for minute and scattered munctations, which necur also on the legs, first antenne, uropods and plengeds. Ilead transwerse and subtriangular, salient in font between the hases of the first antenne. Eyes very large and reniform corering nearly all the upper surface of the head.

lirst antemat when bent backward attaining anterior margin of hirst thome segment: first two segments large and flattened; thirel joint cylindrical; flagellum tapering, made up of about a duzun sermonts. Sormel antenne when reflexed extending heymd first theracic sexment; first two segments short and comfresicel: third somewhat longer; fourth and fifth longer and nearly cylindrical, followed hy a tapering flagellum which is about as long ats peduncle and composed of fifteen to twenty segments.

lirst thoracic segment at anterior margin scarcely broader than leat. expanding rapidly hackward, excavated in front somewhat for the acommondation of the eyes. Second, third, and fourth secoments each a little shorter than first; fifth and sixth somewhat longer; serenth shorter than sixth. Coxal plates distinctly demareated from segments except the first one; those of scomel, third, and fourth segments rounded behind but those of sucecoling segments hecoming acute and extending backwards. First three pairs of lecss short and armed with strong, hooked diatyls: funrth to serenth legs of different form, slender; seventh fatir only slingty developed in young but never quite as large as sixtl which is the largest.

Whemon scarcely namower than last thoracic segment and scarcely tapering to the fifth segment. Last segment triangular, with siles but litle dilated and pointed at the tip. Uropods

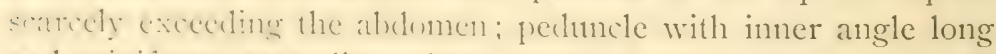
ancl spiniform, extending whole length of inner margin of inner ramus: and ciliated toward tip); ranni flattened, outer one elongate 
ovate, obtuse; inner with margin straight and outer margin curved and emarginate near the tip. Both rami and posterior portion of telson ciliated.

Length $50 \mathrm{~mm}$.

Distribution: between delta of the Mississippi and Cedar Keys, Florida; off Marthas Vineyard; Fishers Island Sound; Gulf of Maine; Gloucester, Massachusetts; Nova Scotia ; Labrador; Newfoundland; Gulf of St. Lawrence; Greenland; Hudson Bay; Ireland; Iceland; North Sea; in the German Sea; Spitzbergen.

This species is parasitic on skates, cod, and halibut.

\section{CYMOTHOIDE.}

Antennæ strongly reduced and without clear distinction between peduncle and flagellum.

Mandibles with palp. First maxillæ with a single lobe consisting of a single joint furnished with four spines at the tip. Second maxillæ bilobed at the tip and provided with numerous spines. Maxillipeds with two-jointed palp, the terminal joint of which is furnished with hooks.

Coxal plates distinct on all the segments except the first. Legs all prehensile, terminating in strong hooked dactyls.

Telson and uropods usually not ciliated.

Parasitic in habit.

\section{Egathoa oculata (Say).}

I8I8. Cymothoa oculata, Say, Jour. Acad. Nat. Sci. Phila., vol. I, p. 398.

I880. Egathoa loliginca, Harger, Rep. U. S. Com. Fish. for I878, p. 393, pl. Io, fig. 66.

Body elongate oval in outline, nearly four times as long as broad, slightly dilated just posterior to the middle. Head broadly rounded in front, as broad as long, and with posterior margin produced in three equal shallow lobes. Eyes large, compound, covering nearly half the area of head above, situated on posterolateral angles of head.

First antennæ as long as head, composed of eight segments and separated at base; first segment short and stout; succeeding two a little longer but scarcely distinguishable from the five 
segments of the lligellum which decrease in size distally. Second antema compusal of atum ten joints, more slender than the first fait which they surpass in length; first two segments broader than the -mowding three, which are latger than the five joints of the flagellum.
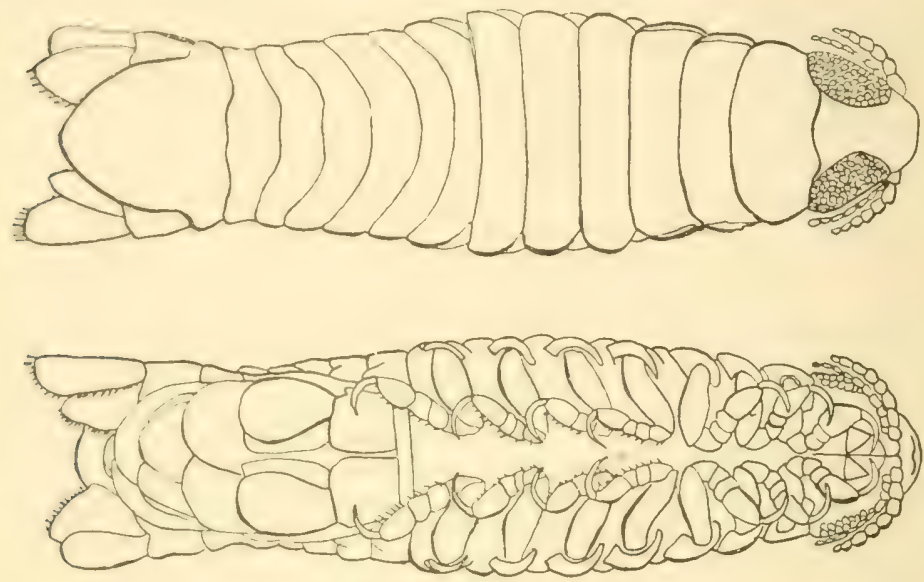

Fisi. (2). Figathou oculata.

lirst thoracic sement shorter than head but longer than

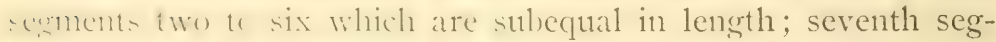
meat ane-third shorter than the sisth; fifth and sixth joints the

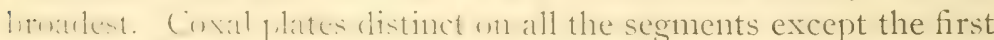
and at lomg a their respective segments. Legs differing but Alighly inum e.ch other: first pair the shortest; last four pairs weaker than the preceding; seventh pair the longest.

Abdomen a little longer than thorax, becoming slightly narmoner puscrorly. Telson as broad at insertion of uropods at thirel semmont, and rumderl behind. Uropods longer than telitil: meter ramus narmon, longer than inner one, with nearly pariallel sides and oldiefuety truncated tip); inner ramus rhomluinlal: peluncle with inner distal angle alcute and only slightly

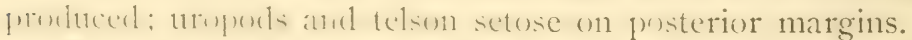

(inter in alcolud, yellowish with minnte black specks which are num alumklint on the abdoment. Fyes black, conspicuous.

Length $\mathrm{I}_{3} \mathrm{~mm}$. 
Distribution: St. Thomas, West Indies; Crisfield, Maryland; St. Johns River, Florida; Fort Macon, North Carolina; Savin Rock, near New Haven, Connecticut.

The species is parasitic; one specimen was obtained from the mouth of a squid by S. F. Clark in 1874 at Savin Rock; other specimens were taken from young mullet at Fort Macon, North Carolina.

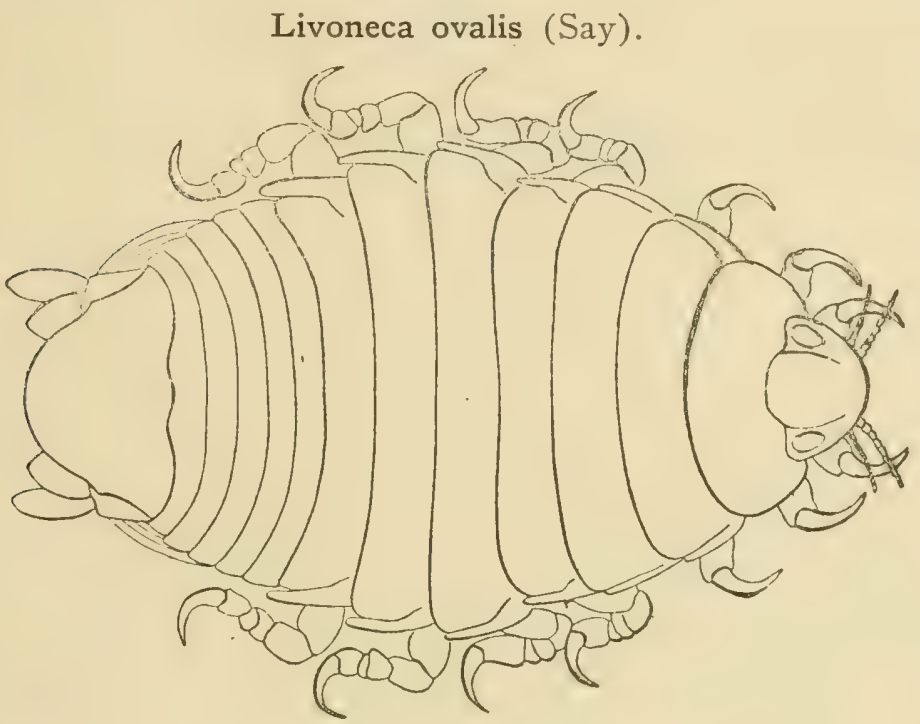

FIG. 63. Livoneca ovalis.

I8I8. Cymothoa oralis, Say, Jour. Acad. Nat. Sci. Phila., vol. I, p. 394 .

I874. Livoneca ovalis, Harger, Rept. U. S. Com. Fish. for I87I-2, p. 572, pl. 6, fig. 29.

I880. Livoncca ovalis, Harger, ibid., for 1878, p. 395, pl. II, fig. 67 .

I have never met with this species myself. The following is from Mr. O. Harger's description.

Body broad, oval, usually oblique and with the sides of unequal length; dorsal surface moderately convex. Head small, rounded in front, trilobed behind, the middle lobe much the largest, the two lateral lobes extending beyond the eyes which are inconspicuous, small, and broadly separated. 
First antenne widely separated at the base, with the first joint short and stont ; second longer and tapering; third about as long as first; Hatgellum longer than peduncle, tapering, five-jointed. second antennat as long ats first pair; first two joints short and stent; the next three joints more slender; flagellum of three or four joints.

First thoracic segment longest; next three a little shorter and efual; fith and sixth still shorter; and seventh the shortest. Coxal plates narrow and obtusely pointed behind, but not extending heront the posterior angle of their respective segments except in the last two. First pair of legs short and stout; succeeding legs increasing in length posteriorly.

Abdomen lapering rapidly at the sides; first five segments sulueculal in length; last segment as long as five preceding segments, flat and broadly rounded behind. Uropods surpassing telson, with hasal segment as long as rami and only slightly froduced at inner angle; outer ramus linear oblong, rounded at end, inner ramus shorter and broader, oblique at the tip.

Length I7-22 mm., breadth IO-I2 mm.

Distribution: Mobile, Alabama; Biloxi, Mississippi ; Florida; Charleston, South Carolina; Virginia; Baltimore, Maryland; New Jork: I.ong Island; New Iaven, Thimble Islands, Connecticut; Woods Hole, Massachusetts; Vineyard Sound.

This species is parasitic on the blue fish, saw fish, scup, sea trout, sun fish, ctc. It is attached usually to the gills and roof of the mouth.

\section{LIMNORIIDE.}

liody sublepressed and capable of being rolled into a ball. Head short and very convex.

Antennæe small, subequal in size.

Mouth parts normal, adapted for biting.

Coxal plates lehind the first segment of thorax distinct and laminar. I.ege of uniform structure, ambulatory in function.

Ahlomen composed of six well defined segments, the last of which is rery laree and shicld-shaped. Uropods comparatively small, lateral; rami not lamelliform. 
Limnoria lignorum (Rathke).

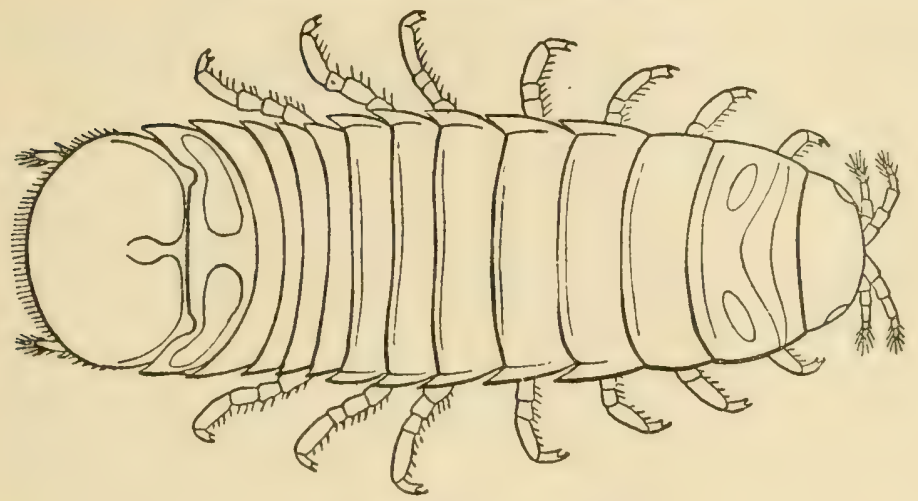

FIG. 64. Limnoria lignorum.

1841. Limnoria terebrans, Gould, Invert. Mass., pp. 338, 354. 1874. Limnoria lignorm, Harger, Rept. U. S. Com. Fish. for I87I-2, p. 57 I, pl. 6 , fig. 25 .

I880. Limnoria lignorum, Harger, ibid., for I878, p. 373.

I899. Limnoria lignorum, G. O. Sars, Crust Norway, vol. 2, p. 76, pl. 3 I.

Body three times as long as wide, oblong-ovate in form, tapering somewhat in front. Head nearly globular, partly covered above by first segment of thorax which is considerably longer than the suberual succeeding ones. Coxal plates distinctly separated on all the segments except the first. Eyes lateral, small, composed of only a few ocelli.

First antennæe stronger than second; flagellum extremely small, triarticulate, with a dense fascicle of setr. Second antennæe with the flagellum about half the length of peduncle and made up of five joints of which the first is much the largest.

First pair of legs larger than the succeeding ones but of the same form. Last pair more slender than the others. Dactyls of all the legs furnished with a large spine at the apex and a smaller one on the concave margin near the apex.

Abdomen scarcely smaller than thorax, tapering but little; first four segments of equal length; fifth much longer; telson elliptical, broader than long, evenly rounded behind and furnished with setæ. Uropods with peduncle strongly tuberculated 
laterally and prolonged to an acute angle between the two rami, the unter one of which is short and unguiform and the inner one is strlinear, alout the length of the peduncle and terminating in a dense tuft of setr.

Color light grayish.

Length $4.5 \mathrm{~mm}$.

1)intrihutiun: Coast of Great Britain; North Sea; Adriatic Seal: colst of Norway: Bchring Island; Pacific Ocean; San Diego, Caliomia: irom Florida to Ilalifax and the Gulf of St. Lawrence.

It occurs above low-water mark but does not usually live far be'ow that line. It has, however, been found by Professor Verrill at a dipth of 10 fathoms in Casco Bay and has been dredged at a depth of $7 / 2$ fathoms in Cape Cod Bay.

This species mat le recognized by its habits, being usually fomml burmung in submerged timlers, which it may penetrate to the depth of half an inch.

\section{SPHAROMIDZE.}

Body short, oval. Convex, capable of being rolled into a ball. Head transverse.

First and scound antenne multiarticulate, with evident distinction into peduncle and flagellum.

Mandibles with palps.

Coxal plates united with their segments.

Dhlomen with the anterior segments short and fused; last segment larace. Cropols lateral; onter ramus movable when present; inner ramus fixed.

\section{Sphæroma quadridentatum Say.}

Isis. Sphormu qundridentum, Say, Jour. Acad. Nat. Sci. Phila., vol. I, p. 400.

18,-t. Spiaroma quadridentum, IIarger, Rept. U. S. Com. Fish. for 187 i-2, p. 569, pl. 5, fig. 2 1.

1880. Spliaroma quadridentatum. ITarger, ibid., for I8, 8 , p. 368 , pl. 9, fig. 53 .

Fucly orate, twice as long as wide. Head twice as broad as long with a frontal horder arising between the eyes and pro- 
duced in a smalı median point. Eyes small, rounded, widely separated, situated in the postero-lateral angles of the head.

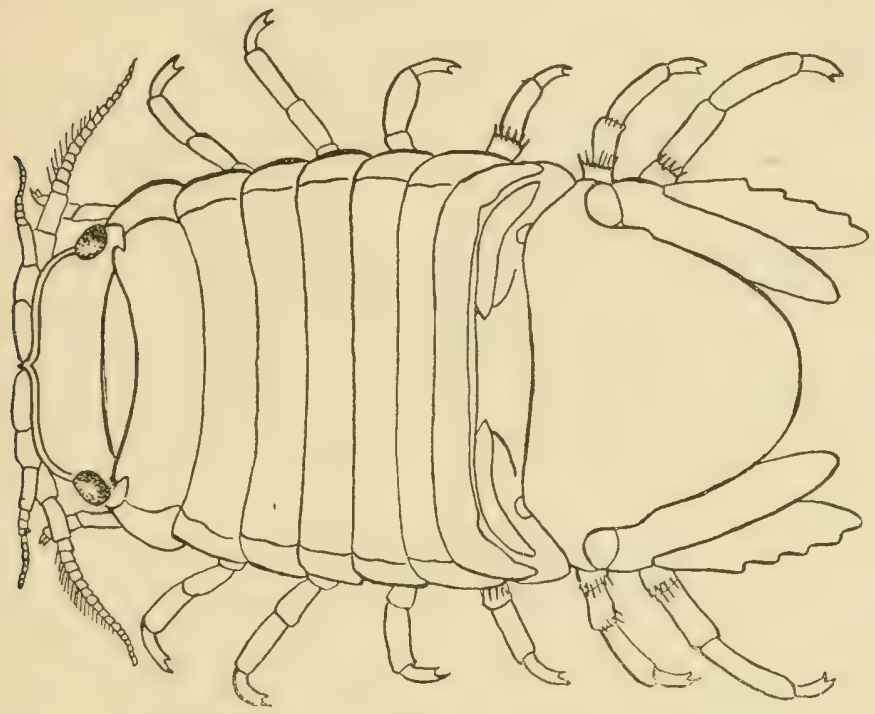

FIG. 65. Spharoma quadridentatum.

First pair of antennxe inserted on under side of head and fitting into groove when the animal contracts; first joint large; second joint small and conical; third joint longer than second and cylindrical in form; flagellum made up of about a dozen segments. Second antennæ longer than first pair, likewise inserted on under side of head; first segment inconspicuous; second segment short; third twice as long as second; fourth and fifth subequal and each a little longer than the third; flagellum as long as peduncle and composed of about fifteen segments.

Maxillipeds with basal segment short and somewhat triangular and with five-jointed palp.

Segments of thorax subequal in length except the first which is longer than the rest : coxal plates distinctly marked off from all segments excent the first; postero-lateral angles drawn out into a narrow and subacute process which is more pronounced in the first four segments.

Legs weak, furnished with long setæ, ambulatory; dactyl in each case short and robust and provided with stout curved spine 
at the tip); first pair with carpus short and triangular and ischium and nerus with long sete on upper margin ; second and third pairs with longer carpus.

Mhlinen composed of two segments; the first one of which resmbles the last thoracic segment but is marked at the sides by two depresions indicating sutures. Telson long and widely romuled pusteriorly, rather strongly contracted laterally at insertion of uropods.

Unupols extending beyond end of telson; inner ramus with montl margins; outcr margin subequal to the inner in length and width, with three or four wide serrations on outer margin.

Culor extremely variable, some individuals of a uniform slatey gray; many marlied dorsally with a whitish, creamy, or pinkish patch margined with black.

Length $8 \mathrm{~mm}$.

Distribution: Florida; Georgia ; Virginia ; Beaufort, North Cimolina; Great Egrg Harbor, New Jersey; Savin Rock, near New Ilaven, Stony Creek, Connecticut ; Provincetown, Massachusetts; Vineyard Sound.

It is fotmel in abundance under stones or creeping about the branches of seaweeds from low-water mark nearly to high-water mark.

Whet disturbed this species curls itself up into a ball with facility and (lrops to the buttom. By this habit of rolling itself into a ball it may he distinguished from all other marine Isopoda of the coast.

\section{IDOTHEOIDEA Or VALVIFERA.}

First thoracic legs not cheliform.

[ropuls lateral, situated ventrally and opening and closing like valves wer the five pairs of branchial pleopods; and attached wn the onter margins to the terminal abdominal segment.

\section{IDOTHEIDE.}

lindy more or less depressed, with segments of thorax of minfom aplecarance. First pair of antenne with muarticulate flagellum. Scencl antennae with flagellum uni-or multiarticulate.

Mandibles without palp. 
Coxal plates sometimes distinct, sometimes fused with their segments. Legs rather strongly built, increasing in length posteriorly; three anterior pairs sometimes strongly subcheliform.

Abdomen with some or all its segments consolidated to form a large termina! plate. Uropods very large, lamelliform, valvelike.

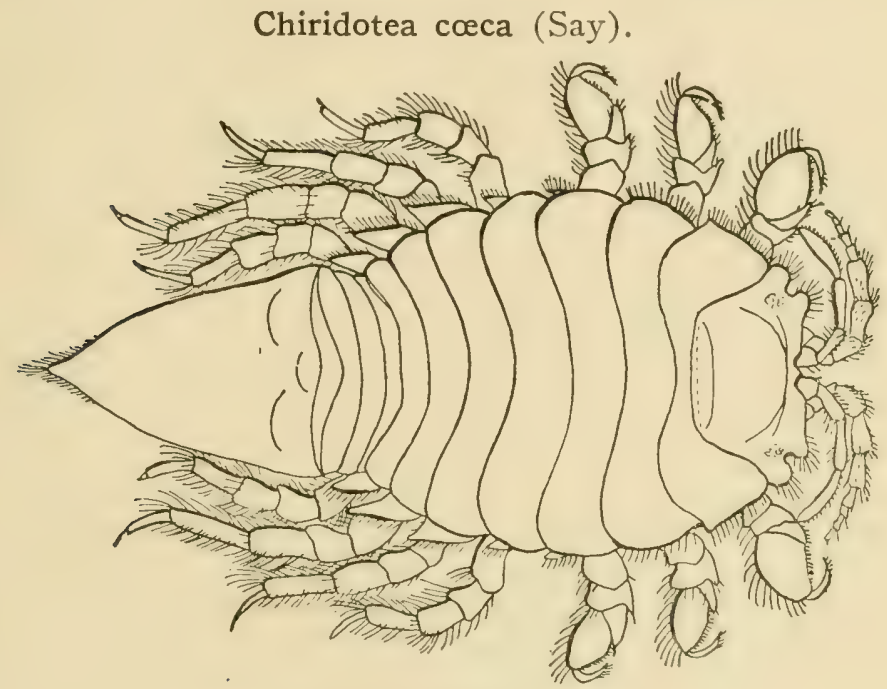

FIG. 66. Chiridotea caca.

I8ı8. Idotea cuca, Say, Jour. Acad. Nat. Sci. Phila., vol. I, p. 424 .

I84I. Idotea coca, Gould, Invert. Massachusetts, p. 337.

IS8o. Chiridotea caca, Harger, Rept. U. S. Com. Fish. for I878, p. 338, pl. 4, figs. I6-I9.

1905. Chiridotea caca, Richardson, Bull. U. S. Nat. Mus., No. 54, p. 353 .

Body ovate, broad and short, tapering to acutely pointed extremity; abdomen nearly one-half as long as whole body. Head only slightly excavated in front for the antennx, with a triangular process not extending beyond the line of the front margin; deeply notched also at antero-lateral angles. Eyes small, inconspicuous, round, situated at base of posterior lateral lobe of head.

First antennæ longer than peduncle of second pair; first joint very short and not dilated; second joint strongly clavate and 
Lumere than his: t thirel and fourth joints equal in length and each alwul twice as kng as first. Second antenne with first joint we -hurl: somel, thirel, and fourtle joints subequal ; fifth joint a litile huger than the forrth; flagellum made up of five joints ami anding in length the last two joints of the peduncle.

Thume sisments suberpual in length and broader than its mid lural length: lirst segment broadly excavated for head. (inal plates distinctly matred off from their segments except the lirat pair: list jum pairs produced behind into acutely pointed

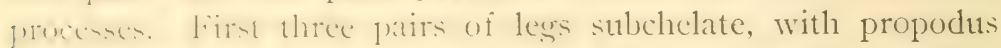
swollen and lacty short and reflex; last four pairs of legs ambulatury and similar in form and increasing in length to the sixth which is the largest; all the legs with abundant setæ.

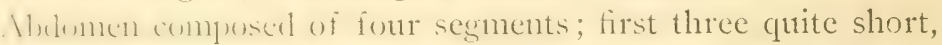
mankning smewhat posteriorly. Telson acutely pointed with lattral sulures of at least one more coalesced segment; lateral andens nuar estremity denticulated, converging for their anterior ladi arulually, and then more rapidly to the apex. Opercular villes ciliated along postero-external margin, in two parts, the smail teminal fatrt representing the outer ranus of the uropods; inner ranus attached to peduncle on the external side.

lts color in life is variable but usually dark grayish. There may be a mothling of light yollowish gray at the sides of the head and body.

Length I2-I $5 \mathrm{~mm}$.

1)istrilutim: Florielat; New Haven. Connecticut; Long Island Sumbl: Ilouds Hoke. I'rovincetown, Nantucket, Nahant, Massachusetts; Vineyard Sound; Halifax, Nova Scotia.

This sforios is common on sand heaches at many localities on the Now linetand coat and Lomg Island Sound. It is usually

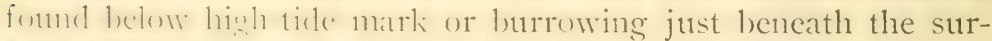
face throwing up a little ridge like a mole, and making a little mund at the (ndel. It swims with ease. It is distinguished from the following species by its latrge size and shorter second antenne which atre lut litte longer than the first pair. From other New limeland lage dat ina le distinguished by the broad subcirculat throws, the articulated flageflum of the second antenne, and a two-valved abdominal operculum. 


\section{Chiridotea tuftsii (Simpson).}

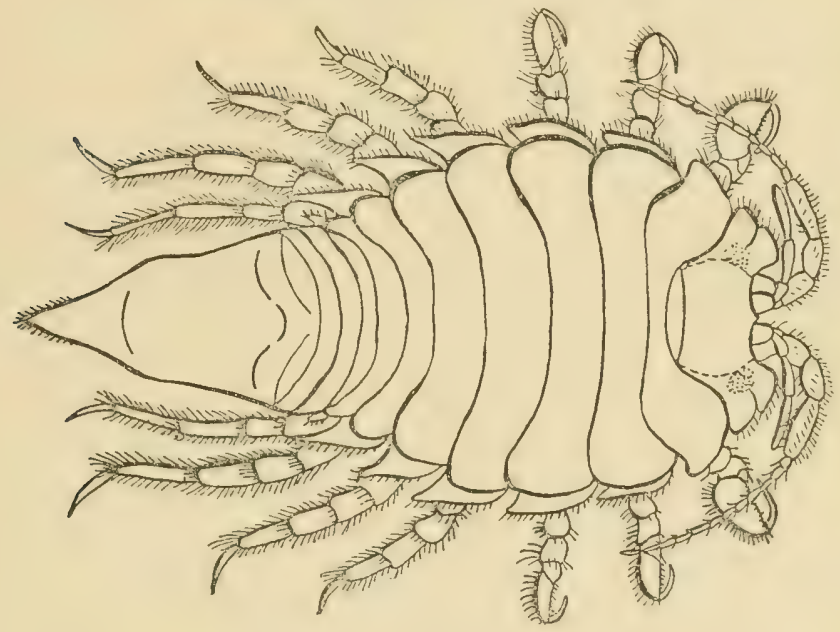

FIG. 67. Chiridotca tuftsii.

1853. Idotca tuftsii, Stimpson, Marine Invert. Grand Manan, p. 39 .

I874. Idotea tuftsii, Harger, Rept. U. S. Com. Fish. for I871-2, p. 569.

I880. Chiridotca tuftsii, Harger, ibid., for I878, p. 340, pl. 4, figs. 20-23.

1905. Chiridotea tuftsii, Richardson, Bull. U. S. Nat. Mus., No. 54, p. 354 .

Body ovate, less than twice as long as wide. Head twice as wide as long, with the front deeply excavate between the anterolateral angles, and produced in a small median point; lateral margins bilobed, the posterior lobe being produced laterally beyond the anterior one. Eyes small, round, more distinct than in the preceding species, situated just within the cleft on the lateral margin.

First antennæ with first joint large and dilated; second joint longer than first, and third longer than second; flagellum made up of a single segment as long as the last two joints of the peduncle together, setose; shorter than the peduncle of second antennæ. Second antennæe with first segment short; second joint twice as long as the first; third joint a little shorter than the second; 
fourth juint at hng as second; fifth joint as long as the two froculing together; flagellum of aloout a dozen segments and longer than peduncle.

lirst senment of thorax deeply excavate in front to accommodate the head. Coxal plates distinctly marked off from their sewments cxecpt the first pair, postero-lateral angles of last four acutely produced. First three pairs of legs subchelate; first pair a little shorter than second and third pairs but with much more rolunt propodus; fourth to seventh pairs ambulatory, less spiny but more setose than in preceding species.

Whlomen composed of four distinct segments of which the last one is twice as long as wide and has lateral sutures indicating a frartly coatesced segment, setose at the acutely pointed tip.

(olor wstully light reddish brown, speckled with darker, or marked with dark transverse patches or bands.

Length $9 \mathrm{~mm}$.

Distribution: Halifax, Nova Scotia; Bay of Fundy; Eastport, Mainc: (itsin Bay; Gloucester Harbor, Massachusetts Bay; Long Island Sound; off New London, Connecticut.

It is found to depths of 25 fathoms. It is also found on sandy shores sinilitr to the preceding species, but is rather more rare. Its halhits are cesentially the same as those of $C$. caca but it can he distinguished from that species by its smaller size and its mulh hinger sccond antenna, which are about twice as long as the first pair, as well as by its more conspicuous eyes.

Idothea mețallica Bosc.

1874. Idotea robusta, Harger, Rept. U. S. Com. Fish. for Is7I-2, p. 569, pl. 5, fig. 24.

I880. Idotca robusta, Harger, ibid., for I878, p. 349, pl. 6, figs. 30-32.

$11,05$. Lethea metullica, Richardson, Bull. U. S. Nat. Mus., No. 54, p. 362 .

lindy bhlong-rovate ahout two and one-fourth times as long ats wite: alulwinen nearly one-half as long as whole body.

Itcinl wirk than long, with front margin slightly excavate, slightly willer linhel than in front. Eyes large and round, compound, and situated at the extreme lateral margin. 
First antennæ extending to end of second joint of second antennæ, with first and second joint not enlarged and subequal; third and fourth joints subequal and each somewhat longer than either of the preceding. Second antennæ with first joint very short; second and third joints subequal; fifth joint a little longer than the fourth which in turn is longer than the third; flagellum composed of eight joints.

Thoracic segments subequal; first embracing the head slightly on either side; lateral portions of the segments curved outward and somewhat upward forming an angle with the portion of the segment to which it is adjacent. Coxal plates from the second to the seventh inclusive, extending entire length of each segment, and very large and wide, increasing in width to the seventh, and giving a serrated appearance to the sides of the thorax.

Legs all more or less alike in character, robust, and with free margins of all the joints and lower margin of the propodus setose.

Abdomen composed of two short segments and a long telson with indications at the sides of coalescence of another short segment. Telson with sides nearly parallel beyond the middle and broadly truncate or even slightly emarginate behind. Basal plate of operculum elongated and with parallel sides; terminal plate less than one-fourth as long and tapering slightly.

Length of male $28 \mathrm{~mm}$; of female $22 \mathrm{~mm}$.

Distribution: Patagonia; New South IVales; Borneo; between Montevideo and Straits of Magellan; southwestern Ireland; Mediterranean; Florida Keys; North Carolina; off Maryland; Chesapeake Bay; south shore of Long Island; Vineyard Sound; Woods Hole, Massachusetts; Newport, Rhode Island; off Marthas Vineyard; near Isles of Shoals; Halifax, Nova Scotia.

This species is pelagic, it is found swimming free as well as among masses of floating seaweeds.

It is easily distinguished from other species of the genus by the telson which is broadly truncate and not the least pointed. From other genera of the New England coast, Idothea is distinguished by the abdomen of apparently four segments of which the first three are short and the third is united in the dorsal region to the large vaulted telson; by the conspicuous two-valved oper- 
culum, and the sereral segnents of the flagellum of the second antenne.

Idothea baltica (Pallas).

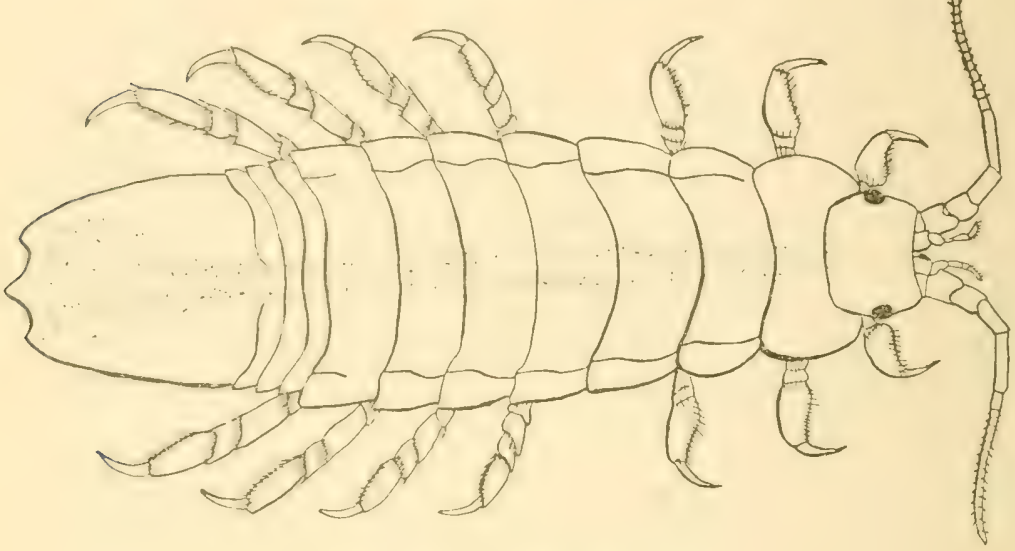

FIg. 68. Idothea baltica.

1841. Stencsoma irrorata, Gould, Invert. Mass., p. 338.

I\$53. Idvici irroratu, Stimpson, Smithson. Contrib. Knowl, vol. 6, p. 39 .

I874. Idotca irrorata, Harger, Rept. U. S. Com. Fish. for I8-1-2, p. 5(x), p). 5. fig. 23; also ithid., for $18,-8$, p. 3+3, p1. 5, figs. $24-26$.

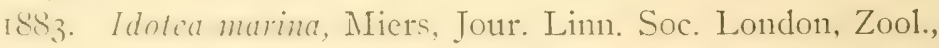
vol. I6, p. 25 .

I899. Idothea baltica, G. O. Sars, Crust. Norway, vol. 2, p. 8o, pl. 32 .

1gos. Idwhed bultiou, Richardson, Bull. U. S. Nat. Mus., No. 54, p. 364 .

Emly oblume-orate, three times as long as wide; abdomen slightly more than onc-third ats long as whole body. I Head wider than lones. slightly excavited in front and narrowing behind.

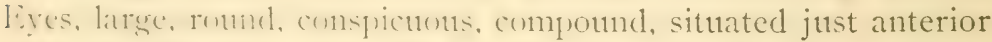
(1) the melian transerec line of the head and at the extreme lateral margin.

Fir-t pair wi antemne with first joint equal in length to the scomel and not expanderl: third and fourth joints slightly longer 
than either of the preceding ones; scarcely exceeding in length the first three joints of the second pair. Second antennæ with first three joints rather short and subequal in length; fourth joint longer than third, and fifth still longer, being twice as long as the third; flagellum of about a dozen segments of which the first is by far the longest and a little longer than the peduncle.

Thoracic segments about equal in length. Coxal plates distinct from their segments and forming a nearly even curved outline, the segments being marked by incisions instead of serrations as in the other species.

Legs more or less alike in structure and increasing in length posteriorly; the first pair much stouter than the succeeding ones.

Abdomen of two short segments followed by a long one which shows indications of coalescence of a third short segment, lateral angles of first two abdominal segments acute. Telson with lateral margins slightly convex and with apical margin produced in middle to an acute point which extends some distance beyond the lateral angles. Operculum with peduncle three times as long as the terminal ramus which is broadly truncate at the apex.

Color varying greatly; frequently nearly uniform light or dark green, or brownish with blackish punctations. Females usually darker than the males which often have a median dorsal stripe.

Length of males 30 to $38 \mathrm{~mm}$; of females $20 \mathrm{~mm}$.

Distribution: Java; Red Sea; New Zealand; Scandinavian coast; Baltic Sea; west coast of Europe to Great Britain; Mediterranean; Caspian, and Black Seas; Bermuda; Barbadoes; Rio Janeiro; North Carolina north to Nova Scotia and the Gulf of St. Lawrence. Within Connecticut the species has been collected at New Haven, Stony Creck, Lyme, Noank, and off Stonington. From Cape Cod southward the species is abundant, but torards the north it is replaced by $I$. phosphorea.

The species occurs on the surface, on floating seaweeds, sometimes far from land. More commonly it is found among seaweeds along the rocky shores of bays or sounds, and among the rocks at low water. In the Woods Hole Survey it was occasionally brought up in the dredge while operating at depths as great as $13 \frac{1}{2}$ fathoms; but the specimens may have been taken in these cases near the surface. 
Idothea phosphorea (Harger).

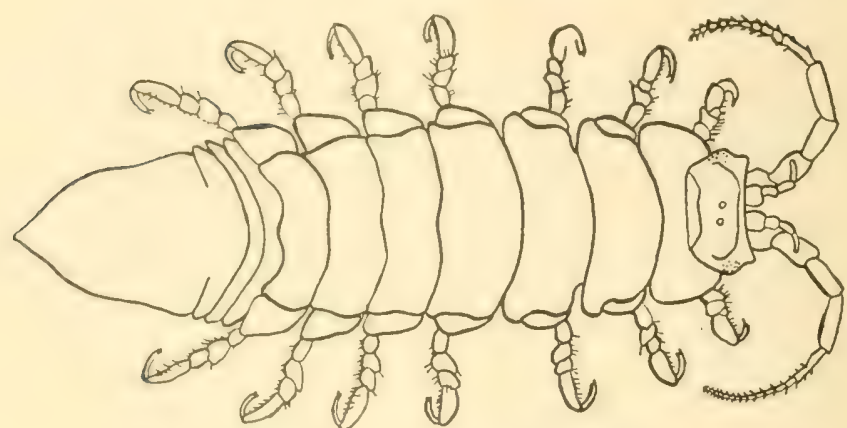

FIG. 69. Idothea phosphorea.

IS - +. Idothea phosphorea, Harger, Rept. U. S. Com. Fish. for $187 \mathrm{I}-2, \mathrm{p} .569$.

1840. Idothea phosphorea, Ilarger, ibid., for 1878, p. 347, pl. 5, figs. 27-29.

1005. Idothea phosphorea, Richardson, Bull. U. S. Nat. Mus., No. 54 , p. 367.

Boxly oblong-ovate, slightly more than three times as long as wide: length of abdomen equal to greatest width of body. Head broader than long, with anterior margin straight on either side of a very slight median excavation. Eyes moderately large, round, compound and placed just in front of the median transverse line of the head at the extreme lateral margin.

First antenne with first joint but little wider than second one, aith of which is subequal in length to the third joint; fourth juint a little longer than any one of the preceding; extending to end of third peduncular joint of second pair. Second antennæ with first joint inconspicuous and second and third joints subequal in length; fifth joint longer than fourth which in turn is longer than the third; flagellum shorter than peduncle and made up of about a dozen segments.

Thoracic segments subermal in length, except the first which is shorter in the mid-dorsal line. Coxal plates distinctly marked ofi from their respective segments, except in the case of the first scoment, and cach one in turn occupying a larger part of the lateral margins and becoming wider posteriorly. Legs of more 
or less similar structure throughout and furnished with setæe along inferior margin of merus, carpus, and propodus.

Abdomen of two short, free segments and a long telson showing indications of a partial coalescence of a third short segment. Telson tapering to a pointed apex, lateral margins exhibiting an obtuse, rounded angle behind the middle so that the posterior part tapers more acutely than anterior part. Operculum with basal plate tapering toward the end and with triangular terminal ramus which is a little longer than broad.

Color very varied, usually dark green or brownish with patches of yellow or whitish. In general the color is darker than in 1 . baltica.

Length $25 \mathrm{~mm}$.

Distribution: coast of New England to Halifax, Nova Scotia, and the Gulf of St. Lawrence.

This species is found in conditions similar to the preceding one but is a more northern form as it is comparatively rare south of Cape Cod while it is abundant in Casco Bay and the Bay of Fundy. It has been collected within the limits of Connecticut at New Haven, Stony Creek, off Saybrook, and Noank Harbor.

It is readily distinguished from the other species of the same genus by the pointed telson.

\section{Edotea triloba (Say).}

I8I8. Idotca triloba, Say, Jour. Acad. Nat. Sci. Phila., vol. I, p. 425 .

1874. Epelys trilobus, Harger, Rept. U. S. Com. Fish. for I87I-2, p. 57 , pl. 6, fig. 28 .

I880. Epclys trilobus, Harger, ibid., for 1878 , p. 358, pl. 7 , fig. $42-43$.

1905. Edotea triloba, Richardson, Bull. U. S. Nat. Mus., No. 54, p. 396.

Body ovate, nearly two and one-half times as long as wide; abdomen less than one-third as long as whole body. Head produced slightly in front with two conspicuous tubercles very close together on either side of middle line, situated on front margin; antero-lateral angles of head produced in rounded lobes upon which the prominent eyes are placed. 
lirst pair wi antemate longer than the second pair; first and ccomel juints cunal in length: third joint twice as long as second; fommh juint alumt two-thirds ats long as preceding. Second

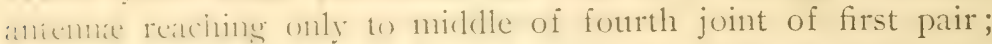
shriter than heat: fundh joint one and a half times as long as thinl which is sulneyul in length to each of the first two joints; lith juint a litile longer than the fourth; flagellum minute, comfuncil uf it single juint which is abont one-third as long as the fifth joint.

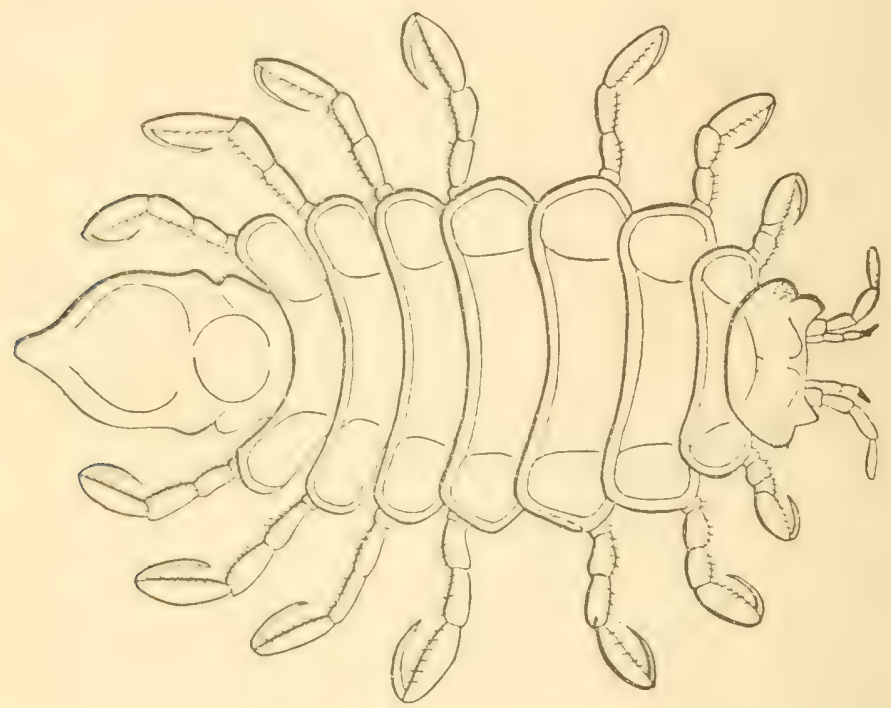

Fig. 7o. Edotea triloba.

Third and fourth joints of thorax longer than any of the where and alow the widest. Coxal plates of none of the segments di-timety spatated: their lateral margins, especially in front,

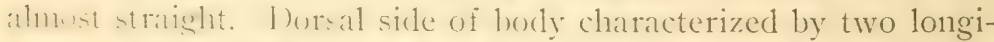

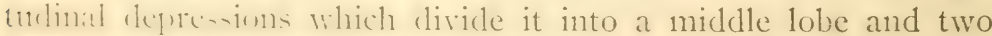
lateral mes which bar each a rounded tubercle. Legs prehensile aml semler wh dactyls which are almost acicular; first pair by far the shortest.

Whimmen ompued of a single segment with slight incisions near the hate indicating another seement partly coalesced; telson with a large romoled prominence situated in the median line at 
the base, followed by a depression so that in a lateral view the abdomen is seen to be in the form of two elevations separated by a deep depression; apex of telson also separated from second elevation by another depression; sides converging rapidly below the middle to a narrow, pointed apex.

Color uniform, dull, usually obscured by adhering particles of dirt.

\section{Length $7 \mathrm{~mm}$.}

Distribution: Great Egg Harbor, New Jersey; Staten Island; Savin Rock, near New Haven, Noank Harbor, Connecticul: Watch Hill, Rhode Island; Vineyard Sound; Provincetown, Gloucester, Massachusetts; Quahog Bay, Casco Bay, Maine.

The species occurs among eel-grass, on piles, and in sheltered places among decaying vegetation and mud on the bottom, from the surface to 3 feet in depth. It is usually covered with adhering dirt..

It may be recognized among the native Isopods by the trilobed character of the back, the abdomen of a single segment, and the second antennæ with only a rudimentary flagellum.

\section{Edotea montosa (Stimpson).}

I853. Idotea montosa, Stimpson, Smithson. Contrib. Knowl., vol. 6, p. 40 .

1874. Epely's montosus, Harger, Rept. U. S. Com. Fish. for I87I-2, p. $57 \mathrm{I}$.

I880. Epily's montosus, Harger, ibid., for I878, p. 359, pl. 8, figs. $44-47$.

I905. Edotea montosa, Richardson, Bull. U. S. Nat. Mus., No. 54 , p. 397.

Body ovate, a little more than twice as long as wide; abdomen slightly more than one-third as long as entire body. Head with front margin triangularly produced and with two low tubercles situated on the anterior margin. Eyes placed on the anterolateral lobes which are rounded.

First antennæ with first and second joints equal in length, third joint twice as long as first, fourth joint slightly more than half as long as third. Second pair of antennæ extending not quite as far as third joint of first pair, with first three joints subequal and fourth and fifth successively longer; flagellum com- 
pored of a single joint onc-half as long as fourth joint of peduncle.

Maxillipeds with triarticulate palp.

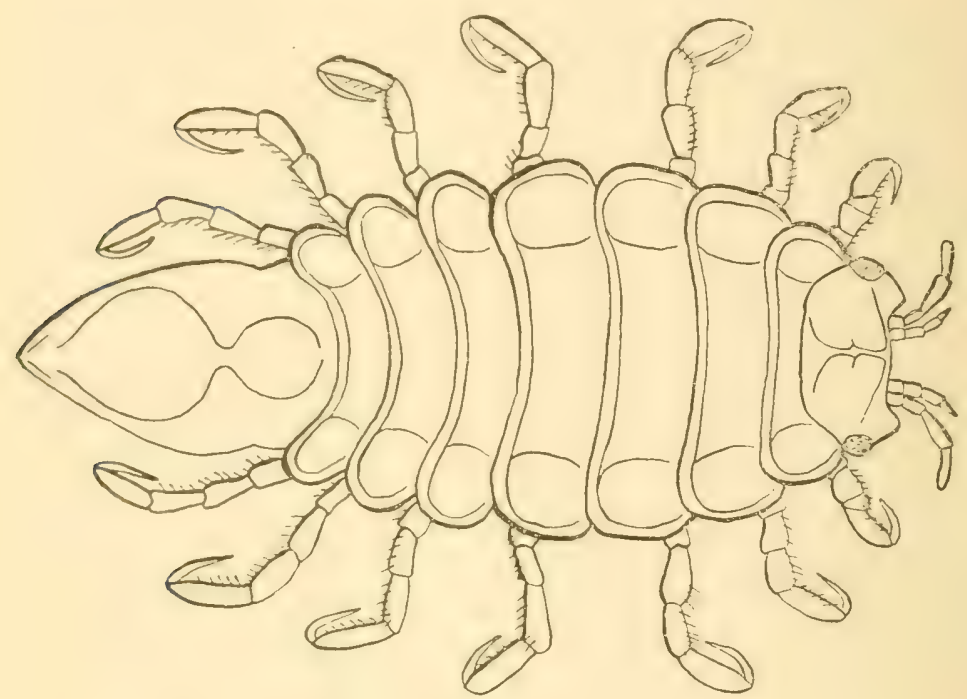

FIG. 71. Edotea montosa.

Third and fourth thoracic segments longer and wider than any of the others. Epimera firmly united with their respective secments lut demarcated by a slight linear depression, with rounded margins.

I.ces all prehencile: first pair much shorter than the other six.

Alulomen composed of a single segment which represents two cualexed as shown hy lateral incisions at the base of the abdomen and a slight duression extending inwards a short distance on either side: dor-al surface with a depression just behind the level of the lateral incisions and another one near the extremity separating off the small teminal point from the large median elevation : siles of aldomen converging to a triangular apex.

Length $9 \mathrm{~mm}$.

1)istribution: Pleck Island Sound ; Long Island Sound; Vineyard Sound: Eastport, Maine: Georeses Bank; Stellwagens Bank; (ascon Bay; Pay of Fundy: I Ialifax, Nowa Scotia; Grand Manan.

The spucies occurs in mud and fine sand at depths of from 8 
to 25 fathoms, and is always concealed by an adhering layer of mud.

It is distinguished from the preceding species by the more rounded lateral margins of the body, the different form of the abdomen, and the absence of tubercles on the lateral portions of the thoracic segments.

\section{Erichsonella attenuata (Harger).}

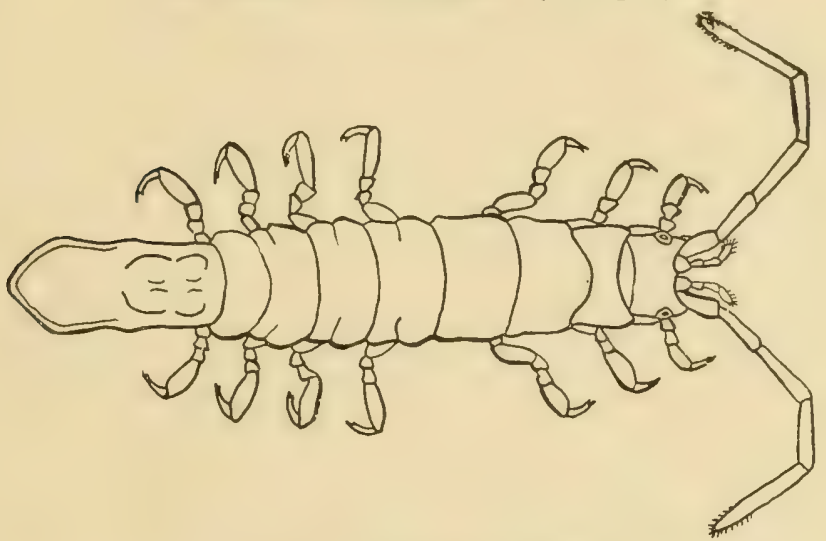

FIG. 72. Erichsonella attenuata.

I874. Erichsonia attcmuata, Harger, Rept. U. S. Com. Fish. for I87I-2, p. 570, pl. 6, fig. 27.

I880. Erichsonia attemuata, Harger, ibid., for 1878 , p. 356, pls. 6 and 7 , figs. 36 and 37 .

I905. Erichsonella attcmuta, Richardson, Bull. U. S. Nat. Mus., No. 54, p. 400.

Body narrow, elongate, about five times as long as wide; abdomen one-fourth as long as entire body. Surface of body smooth throughout. Head wider than long with anterior margin slightly excavate between the prominent antero-lateral angles, with a prominent elevation between the eyes, which are small, compound, and situated half way between anterior and posterior margins of the head on the lateral margins.

First pair of antennæ with first joint large and dilated; second joint a little shorter than the first and half as wide; third and fourth joints subequal in length and each one and a half times as long as the second; extending slightly beyond the second joint 
of the second antennax. Second antennx more than half as long as lundy with the peduncular joints increasing in length to the fourth; fifh joint a little shorter than fourth; flagellum made up of a single joint a little longer than fourth joint.

first eegment of thorax slightly shorter than any of the others except the seventh; second to fifth segments subequal in length; sixth joint, a little sherter than the preceding ones; third segment broadest. Coxal plates distinctly separated on all the segments includling the first, placed in the first three segments on the lateral margin anterior to the middle, in the fourth segment at the midlle, and in succeding segments behind the middle; producing a somewhat angular appearance to the otherwise very even outline of the body. Legs ambulatory and furnished with bi-unguiculate dactyls.

Abdomen composed of only a single segment; with a small lateral process on either side about one-third the distance from the base to posterior end; posterior to the lateral processes the sides are parallel for about one-half the distance and then converge to a rounded apex. Operculum with basal plate more than three times as long as broad, and terminal plate elongated and obtusely triangular.

The color in life is usually uniform dark green, sometimes with an obscure dorsal stripe of a lighter color.

Length I 5 num.

This species has been collected at Great Egg Harbor, New Jersey: and Noank, Connecticut. It is not a common species although it was abundant on eel-grass at the first mentioned locality in April, I87 I.

It may be distinguished from the other genera of isopoda of Connecticut by the fiagellum of the second antennx which is clavate and from the following species by its slender form and regular outline.

\section{Erichsonella filiformis (Say).}

ısıs. Stenusoma filiformis, Say, Jour. Acad. Nat. Sci. Phila., vol. I, p. 424 .

18;+. Erichsonia filiformis, Harger, Rept. U. S. Com. Fish. for $1871-2$, p. 570 . 
1880. Erichsonia filiformis, Harger, ibid., for I878, p. 355, pl. 7, figs. 38-4I.

I905. Erichsonella filiformis, Richardson, Bull. U. S. Nat. Mus., No. 54, p. 401.

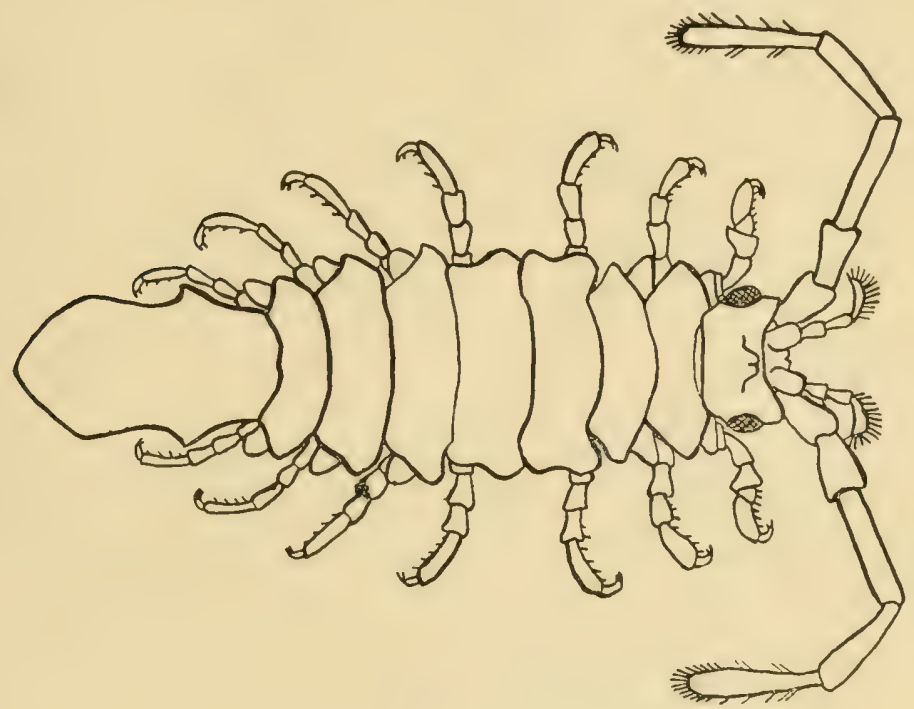

FIG 73. Erichsonella filiformis.

Body oblong-ovate, about three and one-half times as long as wide; abdomen as long as greatest width of body. Head with front margin deeply excavate between the prominent anterolateral angles; dorsal surface of head with a prominent, rounded elevation bearing two slender, rounded tubercles, one on each side of the middle line. Eyes large, round, compound, situated at about the middle of the head at the extreme lateral margins.

First antennæ with basal joint large and dilated; second and third joints subequal and only slightly shorter than first; fourth joint a little longer than third; extending to end of third joint of second antennæ. Second antennæ with first joint very short; second and third joints subequal in length and equal to the first two joints of the first antennæ combined; fourth joint nearly twice as long as third; and fifth shorter than fourth; flagellum clavate, as long as fourth joint, extending when retracted about as far as hind margin of fifth thoracic segment. 
Thuracie segments, each with a smaller median tubercle near its pusterior margin; first two segments with lateral margins producel in rery actute processes, one on either side of each segment; lateral parts of third and fourth segments produced on each side into two acute processes of which the anterior one is the larger; list three segments with anterior part of lateral margin acutely froduced. Cixal plates distinct, that of first segment being acute and anterior in its position; that of the second being bilobed, the npper division concealing the smaller acute lower one; coxal filates of thirt and fourth segments acute but not very conspinous: those of the last three segnents also acute and attached to fusterior part of segment. This condition of the coxal plates and latcral maruins gives the appearance of fourtecn teeth on each side of the thorax. Legs all more or less similar and terminated by a subchelate propodus and dactyl.

. Thiomen composerl of a single segment which is produced on eibler side in an acute angular process about one-third the distatne from the hase to the apex; lateral margins diverging very slightly behinel the angular processes for one-third the length of the aldemen and then converging rapidly to a triangular apex which is rounded. ()perculum a little more vaulted and shorter than in the preceding species; hasal plate less than three times as long as wide, terminal plate triangular.

cislor wstlally dull, neutral tint without bright markings.

Length I I $\mathrm{mm}$.

1)istribution: The Bahamas; Florida ; Great Egg Harbor, New Jersey ; Iong Island Sound; Vineyard Sound; Nantucliet Sound; Fishers Island Sound: Thimble Islands and Noank, Connecticut. It is mistally frumel in tide-pools or among eel-grass and alga and in sand and gravel to a depth of 18 fathoms.

The species may be distingruished by the clavate flagellum of the scomol antenlie and the strongly serrated outline of the sides.

\section{ASELLOIDEA Or ASELLOTA.}

First thoracic legs not cheliform; uropods terminal, biramous ; onter branch of pleopods never two-jointed; pleopods exclusively hranchial, senerally covered hy a thin opercular plate (the modified first pair). 
Second pair of antennæ elongate.

Epimera very small or obsolete.

Abdominal segments all fused together forming a broad, shield-like plate.

Mouth parts normal; maxillipeds furnished with an epipod and five-pointed palp.

\section{ASELLID正.}

Body broad, depressed. Head without rostrum. Caudal segment large, shield-like. Eyes small, lateral.

Antennæ with multiarticulate flagella; superior pair much smaller than inferior pair.

Mouth parts normal.

Pereiopods ambulatory, except the first pair which are subchelate.

Pleopods, four pairs in female; the first very small, not operculiform; the three succeeding pairs biramous and lamelliform; the outer ramus of sccond pair forming an operculum. In male, five pairs of pleopods, an additional one between the first and second forming the copulatory organs.

Uropods large, biramous, with rami styliform or lamellar.

\section{Asellus communis Say.}

I8I8. Ascllus communis, Say, Jour. Acad. Nat. Sci. Phila., vol. I, p. 427 .

I841. Asellus vulgaris, Gould, Invert. Mass., p. 337.

I905. Ascllus communis, Richardson, Bull. U. S. Nat. Mus., No. 54 , p. 420 .

Body oblong-ovate, about three times as long as wide; thorax and abdomen of equal width. Head narrower in front than behind and with anterior margin excavate. Eyes small, round, compound, situated laterally half way between front and hind margins.

First antennæ extending to the middle of last joint of second pair; second joint longer than third which in turn is longer than the first; flagellum made up of about fourteen joints. Second antennx more than half as long as body; fifth joint of peduncle one and two-thirds as long as fourth joint which equals the length of the first three joints together; flagellum much longer than peduncle. 
Mandilile's with triarticulate palp. Maxillipeds with fivejointed palp.

Firsi pair of leess sulchelate; carpus very minute; propodus (1) hols. with hind margin bearing sereral stout spines at junction wilh palm ; dactyl nearly as long as propodus and deeply serrated. suceceling legs with numerous spines; merus prolonged on anterior margin and armed with a group of long spines. Coxal plates very small.

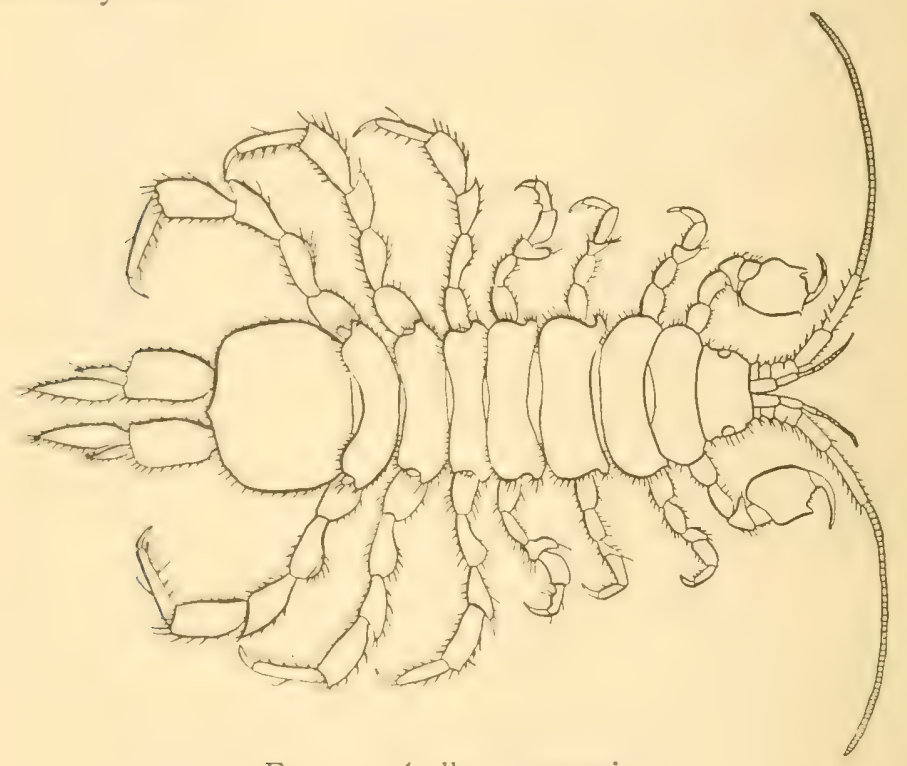

FIG. 74. Asellus communis.

Aldomen composed of two short segments which are visible only on the mid-dorsal line and a large terminal one which is neatrly ats long as it is wide and has the postero-lateral angles rumbled and the posterior margin produced in a broad triangular process between the uropods. Uropods as long as last segment of ablomen; rami styliform, inner ramus as long as peduncle, outer one about two-thirds as long.

\section{Length I5 $\mathrm{mm}$.}

1)istrilution: Potomac River: Schuvlkill River, Pennsylvania; Cincinnati, Ohio; Mississippi; Michigan; Illinois; Indiana; Maseachusetts; Rhode Island; New Haven, Canaan, Berlin, Connecticut. 
This is a very abundant species, occurring everywhere in brooks and ponds, under stones, and crawling over the stems of water weeds. It is very tenacious of life; a single specimen survived in a vial containing a small amount of clean water for a space of three months, with nothing to feed on except possibly the cork of the vial which lay on its side for part of the time. This specimen, together with several others about $5 \mathrm{~mm}$. in length, was brought to me by Mr. S. C. Ball who found them in water drawn from a faucet in New Haven in I9IO.

\section{JANIRIDE.}

General appearance like that of the Asellidæ but with the lateral margins of head always lamellarly expanded. Eyes, when present, subdorsal.

First antenne sometimes well developed, with multiarticulate flagellum, sometimes very small and with rudimentary flagellum. Second antennæ always longer than first pair, with peduncle of six segments and with small scale-like appendage external to the third joint.

Mouth parts normal.

Legs subequal in length, with dactyls bi- or tri-unguiculate; first pair sometimes differing from others in being prehensile.

First pair of pleopods in female in form of single, large opercular plate; in male constituting the median piece of the compound operculum, the lateral pieces of which are formed by the copulatory organs. Uropods biramous.

\section{Jæra marina (Fabricius).}

I853. Jara çopiosa, Stimpson, Smithson. Contrib. Knowl., vol. 6, p. 40, pl. 3, fig. 29.

I868. Jara albifrons, Bate and Westwood, Brit. Sess. Crust., vol. 2, p. 317 .

I874. Jara copiosa, Harger, Rept. U. S. Com. Fish. for I87I-2, p. 57 I.

1880. Jara albifrons, Harger, ibid., for I878, p. 315, pl. I, figs. 4-8.

I899. Jara marina, G. O. Sars, Crust. Norway, vol. 2, p. I04, pl. 43 . 


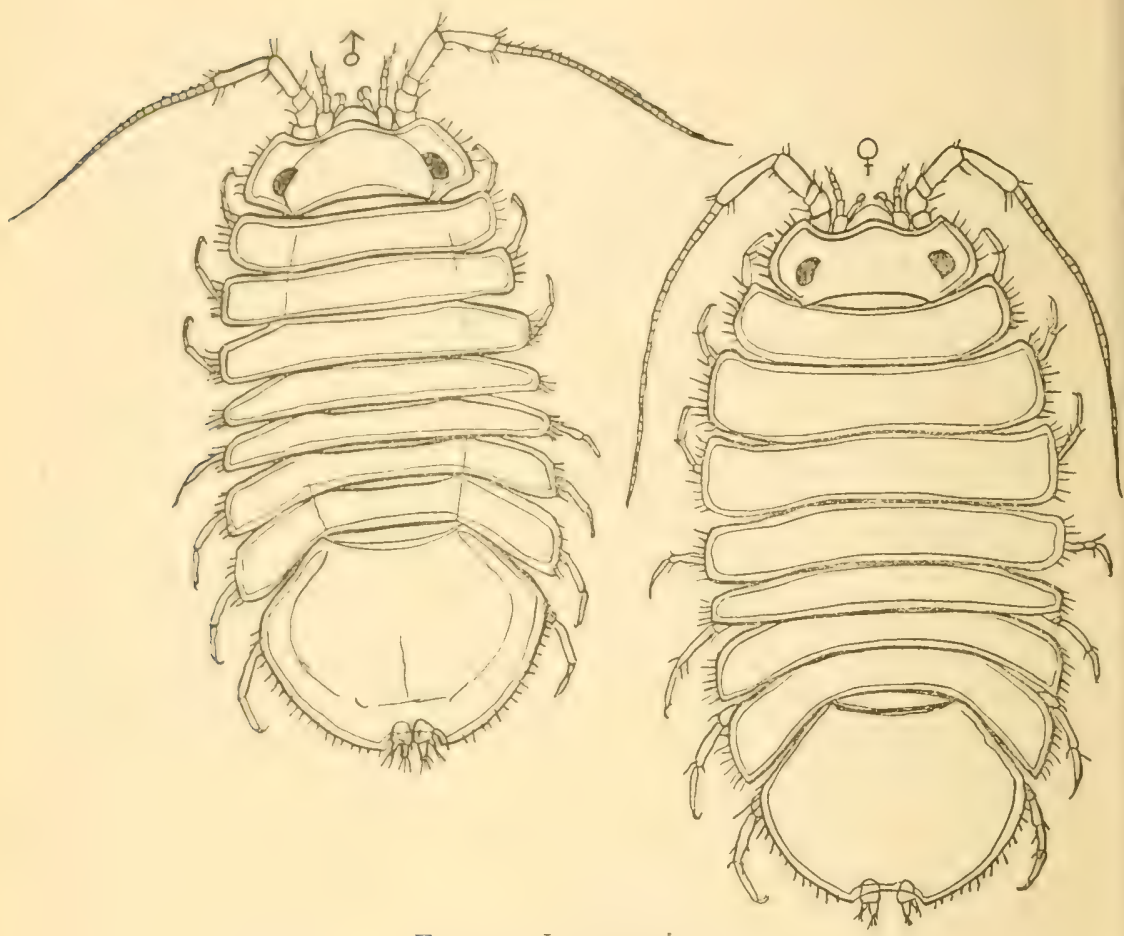

FIG. 75. Jera marina.

I905. Jara marina, Richardson, Bull. U. S. Nat. Mus., No. 54 , p. 450.

Bexly oblong-ovate, about twice as long as wide; abdomen onc-hali as long as greatest body width. Head twice as wide as long, with front margin produced in middle in a large rounded lobe: lateral margins straight and sparsely setose, posterolatemal angles romuled, antero-lateral angles not greatly produced. Eyes small, oral, compound, situated dorsally near posterior margin of head.

lirst antenne with first joint large and dilated; second joint much narrewer and slightly shorter than first; succeeding joints each decreasing in length and width; flagellum of two joints; not extending to fourth segment of second antemne. Second antemite with hirst three juints short and subequal; fourth joint robust and as long as first three combined; fifth joint the longest; 
flagellum composed of about eighteen segments and reaching as far as hind margin of fifth thoracic segment.

First three thoracic segments subequal in length and longer than the last four which are also subequal in length, except the fifth which is shorter than the preceding. Lateral margins sparsely setose and projecting so as to cover the basal joints of the legs but coxal plates not distinct, lateral margins of first three segments squarish, of fourth and fifth segments rounded, and of last two segments obtusely angulated behind. Legs all of similar form, ambulatory, but increasing in length behind.

Abdomen composed of a single joint which is setose on the margin and rounded behind with a small median excavation for the reception of the uropods. Uropods scarcely projecting beyond the general outline of abdomen, biramous, with short stumpy peduncle and outer ramus about one-half as large as inner.

Color very variable, commonly dark, slaty gray with dots or small blotches of yellowish.

Length, according to Harger, extremely variable, females frequently bearing eggs when less than half the length of specimens figured which is about $7 \mathrm{~mm}$. The males are at least onethird smaller than the females.

Distribution; North Sea; Baltic Sea; Greenland; Finland; Denmark; Scotiand; England; Bay of Fundy; Labrador; Eistport, Casco Bay, Maine; Gloucester, Provincetown, Massachusetts, Vineyard Sound; Noank Harbor, Stony Creek, Newv Haven, Connecticut.

This species is quite active in its habits and is found crawling over rocks and barnacles, and especially beneath rocks and drift wood, often nearly up to high-water mark. It is sometimes found in the burrows of Limnoria. It has been noted by McMurrich to breed from the middle of June to the first week in September.

It is distinguished readily from the other marine Isopoda of Connecticut by the short uropods, arising from a notch at the apex of the rounded abdomen and the multiarticulate flagellum of the second antennæ.

\section{BOPYROIDEA or EPICARIDEA.}

First thoracic legs not cheliform; uropods terminal, but sometimes pleopods and uropods are absent; when present pleopods 
are cxclusively branchial and not covered by an operculum. Parasitic forms.

These are the most degraded forms of Isopoda; in some instances the fully-grown female represents merely a simple sac filled with wat, and withont any trace of segmentation or of limbs. In all cases the male is much smaller than the adult female and is sencrally fornd clinging to the genital region of the female like a parasite.

\section{BOPYRID王.}

IBoly of female distinctly segmented and somewhat asymmetrical. Eyes, when present, dorsal.

Both pairs of antennæe rudimentary.

Legrs, seren pairs, sometimes obsolete on one side, all of same structure, short prehensile. Coxal plates obsolete or distinct. Marsupial plates five pairs; of which the first pair is made up of two segments.

- 1hiomen more or less distinctly defined. Uropods, when present, simple, lanceolate.

Male, symmetrical. Head rounded in front. Thoracic segments distinct. Legs similar, prehensile. Segments of abdomen sometimes distinct, sometimes united.

Parasitic on decapods.

\section{Stegophryxus hyptius Thompson.}

ryoz. Stiyophrirus hyptius, Thompson, Bull. U. S. Fish. Com., vol. 2 I, p. $53-56$, pls. 9 , Io.

Iyos. Stryophrirus hiptius, Richardson, Bull. U. S. Nat. Mus., No. 54 , p. 532 .

1 specie of Popyrid which is parasitic on the gills of I'anums longicurpus (hermit crab), collected at Woods Hole, Halley I lathor, Naushon, Edgartown, Massachusetts, and VVarwick, Rhode Island.

\section{Probopyrus pandalicola (Packard).}

ISRI. Bopyrus palamoncticola, Packard, Zoology for High Schools and Colleges, p. 288.

ino5. P'robopyus pandulicola, Richardson, Bull. U. S. Nat. Mus., No. 54, P. 554 . 
The following description is from Miss Richardson's Monograph on the Isopods of North America.

"Head deeply set in thorax; anterior margin straight; posterior margin rounded. Eyes wanting. Ovarian bosses present on the first four segments of the thorax at the anterior part of the sub-lateral margin; epimera evident as narrow plates lateral to the ovarian bosses. The epimera occupy the entire lateral margins on the last three segments. The segments of the abdomen are distinct. The terminal segment is broad, more or less bilobed. The pleopoda consist of five pairs of double-branched lamellar appendages, closely crowded together on the ventral side of the abdomen.

"The five pairs of incubatory lamellæ surround a large open area normally filled with eggs. The first pair have the terminal lobe of the distal segment large, well defined, and incurved.

"All the legs have a high quadrangularly shaped expansion or carina on the basis.

"Male with all the segments of the thorax distinct, and with the lateral margins contiguous. First four segments of the abdomen well defined at the sides, but fused in the middle of the dorsal surface. The last two segments form a single large piece, the fused terminal segment being indicated only by a small median point on the posterior margin. The body is a little more than twice as long as wide. Eyes are present. The rudimentary pleopoda are pairs of small oval processes, one pair on each abdominal segment. The abdomen is about one and a half times as broad as long."

This species is parasitic on Palcmonetes vulgaris (a prawn) and has been reported from New Hampshire to Florida; East Providence, Rhode Island; Acushnet River, Massachusetts; Baldwin Ledge, Mississippi; Brooklyn, New York.

\section{ONISCOIDEA.}

Body more or less depressed, oval or oblong in form, in some cases capable of being rolled into a ball. Head generally small and more or less sunk into first segment of thorax, no true rostral projection.

First antennæ always of very small size, never composed of more than three segments, the last of these being often rudimen- 
tary. Second antenne of normal structure and moderate length, seldom exceeding half the length of the body.

Mouth prits adajted for hiting. Mandibles without palp. Maxilliperis not completely cowering the other mouth parts and with terminal parts more or less reduced.

lhorax composed of seren well delined quite similar segments, the lateral fart: of which are gencrally expanded to thin, fornicate plates.

Abdomen composed of six well defined segments.

l'leppots five pairs, which are respiratory in function; the inner plate being of very delicate spongey structure whereas the onter is more strongly chitinized and covers the inner like an (1perculum. Sir cavities are sometimes present in this operculum. Uropods biramous, with rami uniarticulate.

\section{Oniscus asellus Linnæus.}

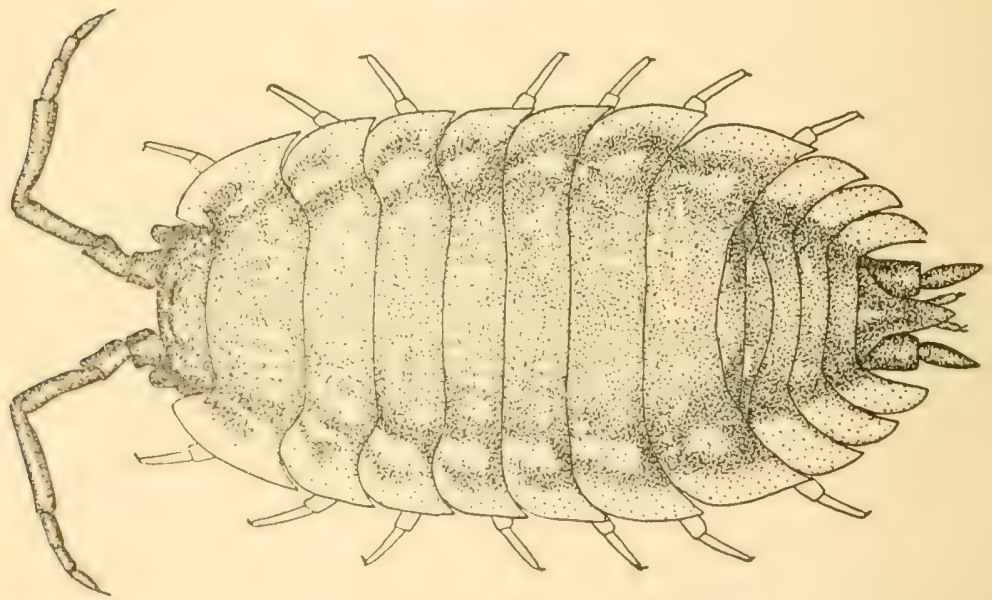

FIG. 76. Oniscus asellus.

I8is. Oniscus affinis, Say, Jour. Acad. Nat. Sci. Phila., vol. I, p. 430.

I841. Oniscus asellus, Gould, Invert., Mass., p. 336.

I899. Oniscus asellus, Sars, Crust. Norway, vol. 2, p. I7r, p. 75 .

1y05. Oniscus asellus, Richardson, Bull. U. S. Nat. Mus., No. 54, p. 600 . 
1905. Oniscus asellus, Paulmier, Bull. N. Y. State Mus., No. 9I, p. I80.

Body oblong-ovate, about one and one-half times as long as wide. Head twice as wide as long, with frontal margin slightly convex, and pronounced antero-lateral lobes which are narrow and elongated and rounded anteriorly. Eyes large, compound, oval, situated at sides of head at base of antero-lateral lobes.

First antennæ very small and inconspicuous. Second pair extending when retracted to posterior margin of third thoracic segment, with first joint short; second and third subequal and each twice as long as the preceding; fourth joint nearly twice as long as third; and fifth joint one and a half times as long as fourth; flagellum composed of three joints and shorter than last peduncular joint.

Thoracic segments of subequal length; first one with anterolateral angles produced to embrace head, extending nearly to the extremity of the antero-lateral angle of head. Coxal plates not distinct but lateral margins of all the segments well expanded and straight, producing an even contour. Legs moderately slender, increasing in length posteriorly.

Abdomen not abruptly contracted; all the segments distinct, the first two considerably shorter than the others and with their lateral margins completely concealed by the last thoracic segment; lateral margins of third, fourth, and fifth segments expanded, and produced and curved posteriorly to continue the oval outlinc of the body, those of the fifth segment being produced backwards strongly as far as the extremity of the last segment. Terminal segment triangular with apex produced considerably and pointed and convex above. Uropods rather produced, with the inner ramus originating far in front of the outer; peduncle extending beyond the middle of last abdominal segment; inner ramus narrow, linear, reaching as far as apex of abdomen; outer ramus narrow lanceolate, extending beyond the apex.

Color, dorsal portion of body dark brown; lateral margins of body and longitudinal rows of spots on either side at union of coxal plates and body segments, light yellow.

Length $16 \mathrm{~mm}$.

Distribution; Greenland; Iceland; Sweden; Norway; Denmark; Great Britain: France; Spain; Italy; Azores; also Woods 
Hhle, Silem, and lieverly, Massachusetts ; New Haven, Connecti(at: I'rovitence, Rhode lskand: New Lork City, Schenectady, New York: Rock Island, Illinois; Maine; Pennsylvania.

This species is found under dead logs, leaves, and stones and is common in lothouses.

It may be recognized among the terrestrial Isopoda by the cren, rominded contonr of the front and the pronounced anterolateral hubes of the head and the three joints of flagellum of second antenna.

Philoscia vittata Say.

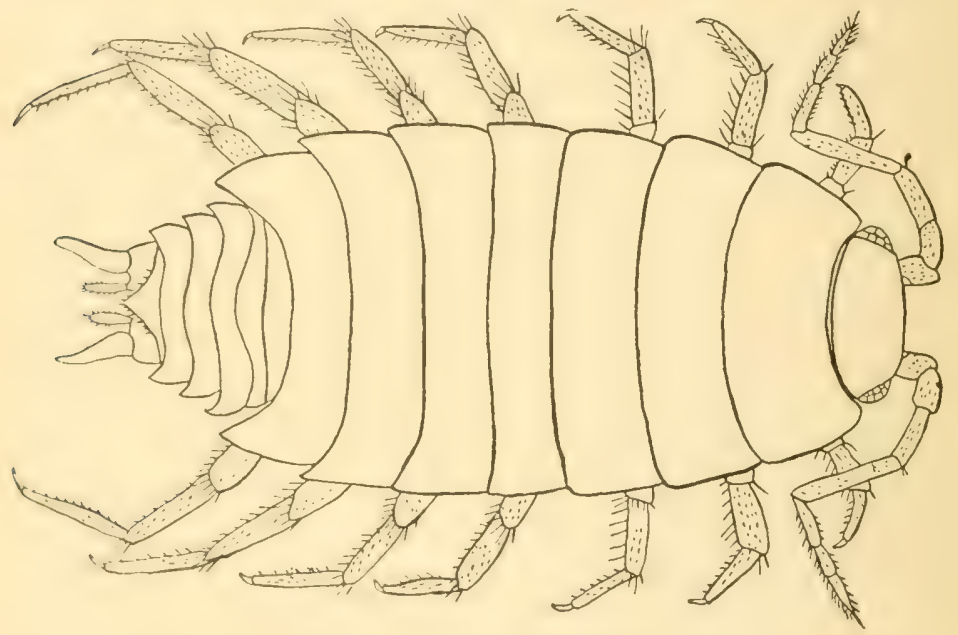

FiG. 77. Philoscia vittata.

Is!s. I'li!usciu rittutu, Say, Jour. Acad. Nat. Sci. Phila,, vol. I, P. 429 .

1.j-t. I'hilescia zittata, Ilarger, Rept. LT. S. Com. Fish. for ISTI-2, p. 569 .

I8So. Philoscia vittata, Harger, ibid., for ı878, p. 306, pl. I, lis. I.

I905. Philoscia vittata, Richardson, Bull. U. S. Nat. Mus., No. 54, p. 605 .

linly wal, mooth, nearly three times as long as wide. Head witce than long, with anterior margin rounded and antero-lateral ander rombled and not produced to lobes. Eyes small, round, compound, situated in antero-lateral angles of head. 
Antennæ minutely hirsute, especially on the flagellum, extending to posterior margin of third thoracic segment; first segment short; second twice as long as first; third segment as long as the second, clavate; fourth nearly twice as long as the third; fifth longer than fourth; flagellum composed of three nearly equal joints; the terminal one of which is tapering.

First thoracic segment longer than the succeeding ones which are subequal; anterior angles of first segment somewhat produced at the sides to embrace the posterior part of the head; second and third segments with their posterior angles less broadly rounded but not produced backward at all; fourth, fifth, and sixth segments with posterior angles increasingly produced toward the posterior end and acute. Legs all ambulatory and increasing in size and length to the last pair.

Abdomen abruptly narrower than the thorax, two-thirds as wide as the last thoracic segment; first two segments with lateral lamellæ nearly concealed by the seventh segment of the thorax; lateral lamellax of the three succeeding segments not large, acute. Telson acute but not prolonged behind and not extending beyond the end of the peduncle of the uropod which is broad. Uropods with rami originating at the same distance from the base; outer ramus narrowly lanceolate, tapering to the tip and exceeding by less than one-half its length the more slender, styliform inner ramus.

Color, dull and somewhat variable, usually brownish with light lateral margins and narrow, median stripe separating the two wide, dark bands.

\section{Length $8 \mathrm{~mm}$.}

Distribution: Great Egg Harbor, New Jersey ; Freeport, Long Island; Salem and Barnstable, Massachusetts; Vineyard Sound; Stony Creek, Connecticut.

This species is found under rubbish and stones on the shore below high-water mark. Say states that it is "very common under stones, wood, etc., in moist situations."

\section{Cylisticus convexus (DeGeer).}

1899. Cylisticus convexus, G. O. Sars, Crust. Norway, vol. 2, p. I86, pl. 8I. 
1905. Cylisticus convenus, Richardson, Bull. U. S. Nat. Mus., No. 54, p. 609.

1105. (Ylisticus comiexus, Paulmier, Bull. N. Y. State Mus., No. 9I, p. I8I.

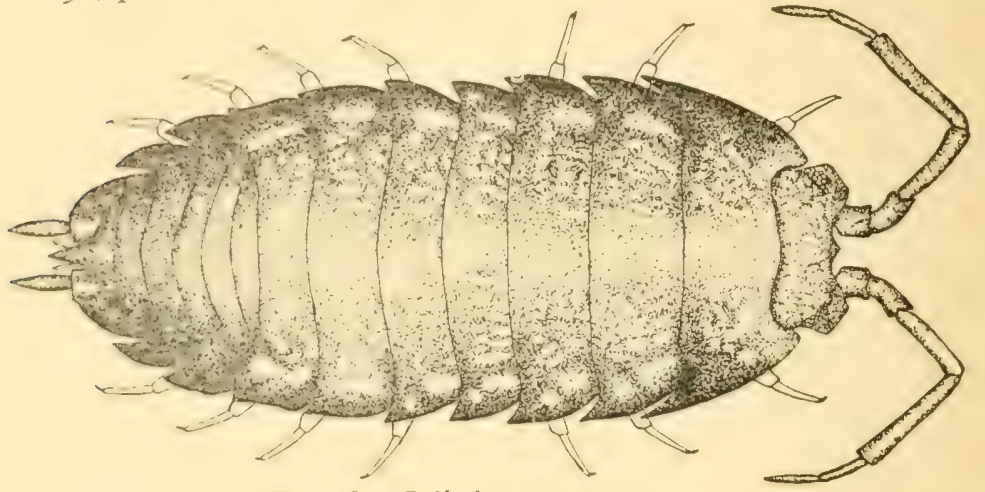

Fig. 78. Cylisticus converus.

Borly oblong-ovate, a little more than twice as long as wide, dorsal surface strongly convex; able to contract into a ball like an armadillo.

Head twice as hroad as long with the antero-lateral angles foreluced in large and rounded lobes; median lobe small and triangulat and with acute apex. Eyes small and compound, situated at the bases of the antero-lateral lobes.

First pair of antennæ inconspicuous, very small. Second pair long and slender with flagellum composed of two subequal joints: peduncular joints increasing in length distally.

Thuracic segments subequal in length; large coxal plates not distinct from their segments; those of first segment expanded to cmbrace the head. extending to base of antero-lateral lobes as well as pusteriorly in acute processes; lateral margins straight. Legs moderate, increasing in size posteriorly.

Vhromen with six distinct segments not abruptly contracted; first two with lateral margins covered by last thoracic segment; third, fourth, and fifth with lateral lamelle prominent and curved pusteriorly to continte the even outline of the body. Telson triansular, conically produced. Uropods considerably produced heyond sencral ontline of hody, with peduncle extending a little leyond the midlle of apical process of telson; inner ramus origi- 
nating far in front of outer one and extending as far as telson while outer ramus extends more than half its length beyond the abdomen.

Color light brown with longitudinal row of yellow spots on either side marking union of coxal plates and segments; also with markings of ycllow wavy lines between the median line and the longitudinal rows of yellow spots.

Length $12.5 \mathrm{~mm}$.

Distribution : Sweden; Norway; Denmark; Germany ; British Isles; Holland; Belgium ; France; and Turkey; also New Mexico; Michigan; Lake Erie, Syracuse, Norwich, New York City, New York; Ohio; Rock Island, Illinois; Washington, District of Columbia; New Haven, Connecticut.

This species is found in woods, under logs, along roads, under stones, in woodsheds, usually in moderately dry places.

It may be distinguished from other terrestrial forms by the great convexity of the body and its ability to roll up into a ball. Armadillidium is the only other terrestrial form capable of rolling into a ball but with this there can be no confusion because of the pointed telson and prominent uropods of Cylisticus.

Porcellio spinicornis Say.

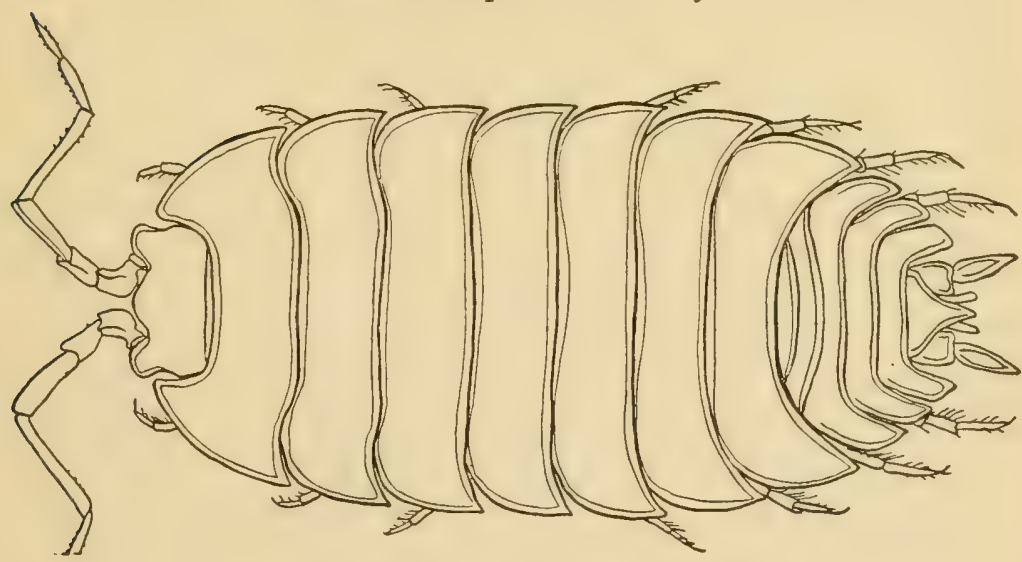

FIG. 79. Porcellio spinicornis.

I8r8. Porcellio spinicornis, Say, Jour. Acad. Nat. Sci. Phila., vol. I, p. $43 \mathrm{I}$. 
Isum. L'oritlio pictus, G. (). Sars, Crust. Norway, vol. 2, p. 177 , pl. 78 , fig. I.

I, 2. Poricllio spinicumis, Stoller, 5tth Rept. N. Y. State Mus., p. 2I3.

rexo5. P'oricllio spinicomis, Richardson, Bull. U. S. Nat. Mus., No. 54, p. 6 I9.

1605. P'oritlio spinicornis, Paulmier, Bull. N. Y. State Mus., No. 9I, p.

budly ublong-oval, considerably depressed; surface rough, with less dense tubercles than in $P$. scaber.

Head with very lirge lateral lobes which are slightly curved ontwards: frontal lobe less prominent, broadly rounded. Eyes large, compound, situated at the base of the lateral lobes.

First pair of antenne inconspicuous. Second pair rather sender and nearly one-half as long as body; second and third pedunculatr joints with a carina on the outside which is proluciel to a dintiform projection; flagellum not as long as last joint uf preduncle, composed of two joints of which the proximal is nearly twice as long as the distal one.

Coxit plates of thorax well developed with posterior corner acmminate. Last pair of legs more strongly built in the male than female, with carpus dilated.

Mrlomen scarcely one-fonth as long as body; third to fifth coxal flates prominent and recurved. Telson strongly produced, one and a half times as long as broad at the base, terminal part actute. ()percular plates of only the first and second segments of alukmen provided with air cavities. Uropods with rather broad outer ramus.

(i)h, yellowish cray, variegated with dark brown patches, generally arranged in five long. series.

Length I3 $\mathrm{mm}$.

1)istribution ; Sweden; Norway; Denmark; Russia ; Germany; France: (ircat Jiriain; I Iungary; also New York City, Niagara Falls, New Iork: Gothen, New Ilaven, Connecticut.

The species occurs in crevices of rocks and on shady limestone ledges (Stoller) and also in damp cellars, etc.

It is distinguished from the two following species by the spotted borly and yellum color, and the flagellum of the second antemme, the first joint of which is a little longer than the second. 


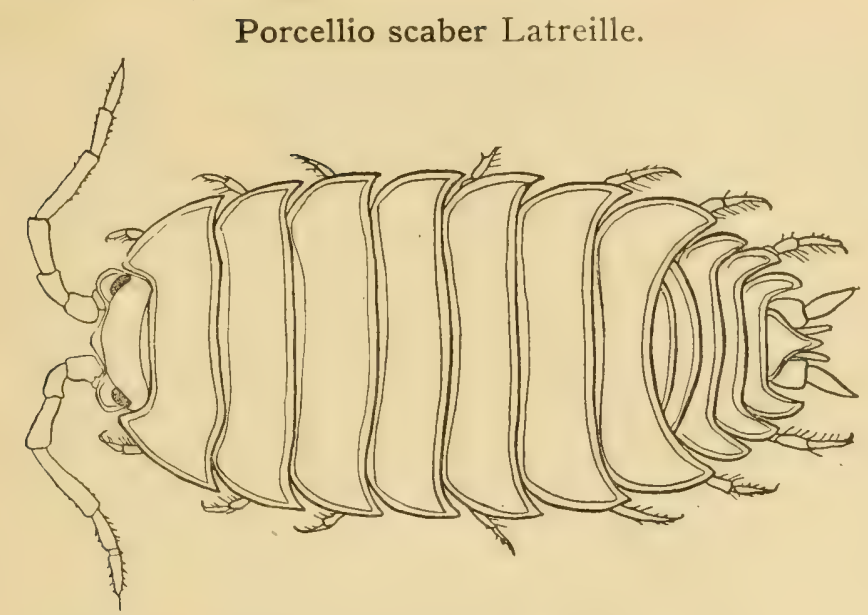

FIG. 8o. Porcellio scaber.

I8I8. Porcellio nigra, Say, Jour. Acad. Nat. Sci. Phila., vol. I, p. 432 .

1853. Porccllio gemmulatus, Dana, U. S. Expl. Exped., vol. I4, p. 725 , pl. 47.

I899. Porcellio scaber, G. O. Sars, Crust. Norway, vol. 2, p. 176 , pl. 77 .

I902. Porcellio scaber, Stoller, 54th Rept. N. Y. State Mus., p. 2 I 3.

I905. Porcellio scaber, Richardson, Bull. U. S. Nat. Mus., No. 54 , p. 621 .

I905. Porcellio scaber, Paulmier, Bull. N. Y. State Mus., No. 9I, p. 183 .

Body oblong-oval, twice as long as broad; dorsal surface convex and very rough with tubercles. Head with lateral lobes large and rounded; frontal lobe less prominent and obtusely triangular. Eyes large and compound, placed at the base of the lateral lobes.

Second pair of antennæ slender and scarcely one-half as long as body; flagellum subequal in length to the last peduncular joint and made up of two subequal joints.

Coxal plates of thorax moderate in size, with their posterior corners acutely produced. Last pair of legs differing very little in the two sexes.

Abdomen at least one-fourth as long as body; coxal plates of third to fifth segments strongly recurved. Opercular plates of 
only first and second segments provided with air cavities. Telson rather strongly produced and terminating in an acute point. Uropods longer than terminal segment, outer ramus broadly lanceolate and comparatively longer in male than female.

Cilor, uniform gray black, sometimes variegated with irregular dark spots.

\section{Length Io $\mathrm{mm}$.}

Disrtihution; world wide. British Columbia; Iceland; Cape uf (imel Ilope; Key IVest, Florida; also West Haven and New Haven, Connecticut.

The species is found under logs and bark in generally dry plites, also under dead leaves and stumps and under boards, in greenhouses.

$\mathrm{It}$ is distinguished from the other species of the genus by the unspotted body.

\section{Porcellio rathkei Brandt.}

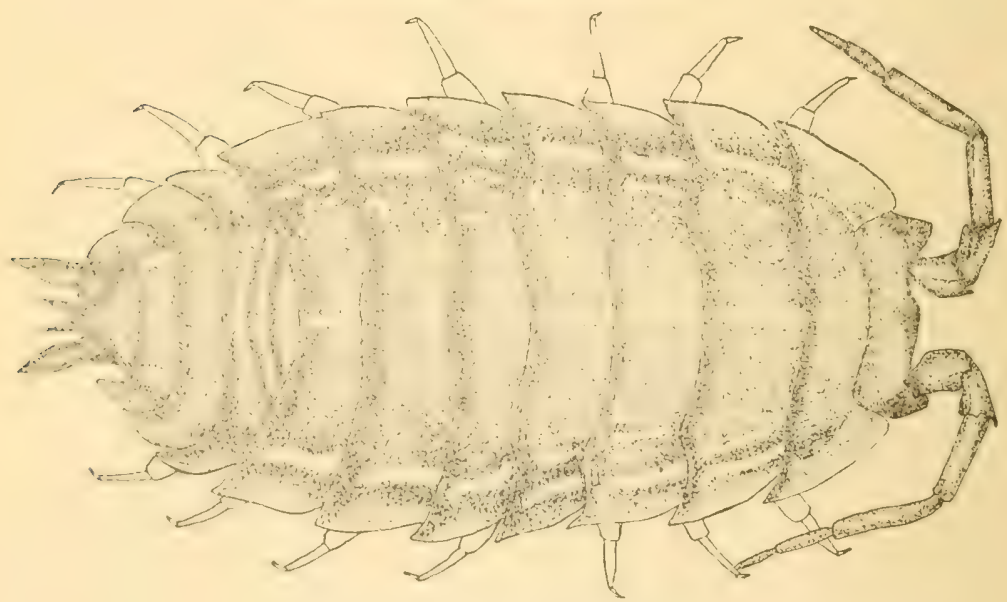

FIG 81. Porcellio rathkei.

183.3. P'urcellio rathkei, Brandt, 13ull. soc. imp. Nat. Moscou., vol. 6 , p. 177 .

isix. I'uriellio rathki, (s. (). Sars, Crust. Norway, vol. 2, p. 180, pl. 79 , fig. I.

1y05. I'orcellio rathkci, Richardson, Bull. U. S. Nat. Mus., No. 54, p. 622 . 
I905. Porcellio rathkei, Paulmier, Bull. N. Y. State Mus., No. 9i, p. 183 .

Body oval, somewhat broader in female than male; dorsal surface rather convex and slightly tuberculated. Head with lateral lobes well developed, rounded; frontal lobe short, obtusely triangular.

Second pair of antennæ rather slender, nearly one-half as long as body; flagellum about as long as last joint of peduncle and made up of two joints of which the proximal one is shorter than the terminal one.

Thorax with coxal plates moderate, subcontiguous, and with posterior corners obtusely acuminate. Last pair of legs stronger in male than female and with carpus remarkably dilated near the base.

Abdomen scarcely one-fourth as long as whole body; third to fifth coxal plates well developed and recurved. Opercular plates all provided with air spaces. Telson subtriangular, with outer part acutely produced and smooth above. Uropods with outer rami broadly lanceolate and with the inner one extending considerably beyond the last abdominal segment.

Color, variable:

Length io $\mathrm{mm}$.

Distribution: Europe; Ohio; New York City; Lake Champlain; Michigan; Maine; Massachusetts; Providence, Rhode Island; New Haven, Connecticut; Washington, District of Columbia; Texas; Georgia.

The species is very common under stones, boards, etc. It is found very often in woodsheds and greenhouses.

It is distinguished from the other species of the genus by its white spots on a gray to black ground; and by the antero-lateral lobes of the head which are smaller than in $P$. spinicomis.

\section{Metoponorthus pruinosus (Brandt).}

I899. Metoponorthus pruinosus, G. O. Sars, Crust. Norway, vol. 2 , p. 184 , pl. 8 o, fig. 2 .

I902. Metoponorthus pruinosus, Stoller, 54th Rept. N. Y. State Mus., p. 213.

I905. Mctoponorthus primosus, Richardson, Bull. U. S. Nat. Mus., No. 54, p. 627. 
1(x):. Metoponorthus prumosus, I'aulmier, Bull. N. Y. State Mus., No. 91, p. I83.

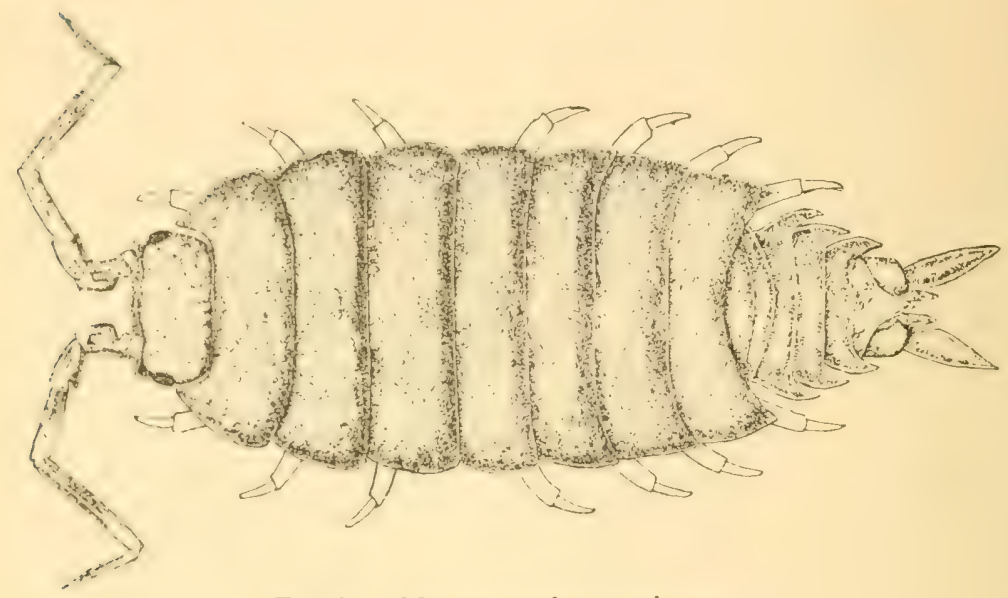

FIG. 82. Metoponorthus pruinosus.

liody olong-ovate, twice as long as wide. Head twice as wile ats long, with anterior margin slightly convex and anterolateral lobes small. Eyes small, composite, situated at base of antero-lateral lobes.

First pair of antenne small and inconspicuous. Second pair with first joint short; second and third cach twice as long as first; fourth wice as long as third; and fifth one and a half times as homg ats preceling: flagellum composed of two joints, the first of which is twice as long as the second and, taken together, almut ats longe as fifth peduncular joint; whole appendage extencling as far as posterior margin of fourth thoracic segment.

first sexment of thorax a little longer than any of the others which are suluepual. Antero-lateral angles of first segment prodiced forwarl to strround the head and extending to base of antero-lateral lobes of head. Epimera not distinctly separated from the segments.

Vulumen at rupty narrower than thorax. All six segments di-tint: lirst two covered laterally by the last thoracic; third, funth, and fifth sewments with lateral parts not greatly expanded; sixh senment triangular in form and half as long as wide at 
the base, apex acute and with slight concavity in its dorsal surface.

Uropods with peduncle not extending as far as apex of last abdominal segment; outer ramus lanceolate and more than twice as long as last segment of abdomen; inner ramus about one-third as long as outer one.

Color, posterior and lateral margins of uniform reddish brown; other parts of a lighter color. Surface of body slightly granulated.

\section{Length $9 \mathrm{~mm}$.}

Distribution: Ohio; Kansas; California; Utah; New Mexico; Texas; Florida; Washington, District of Columbia; Virginia; Maryland; New York City; Massachusetts; VVest Indies; Bermuda; Bahamas; Europe; North Africa; Venezuela.

The species is found under logs and decaying vegetable matter, in greenhouses, along walls, and in dwellings.

It may be distinguished from other terrestrial forms by the fact that the abdomen is abruptly narrower than the thorax.

\section{Actoniscus ellipticus Harger.}

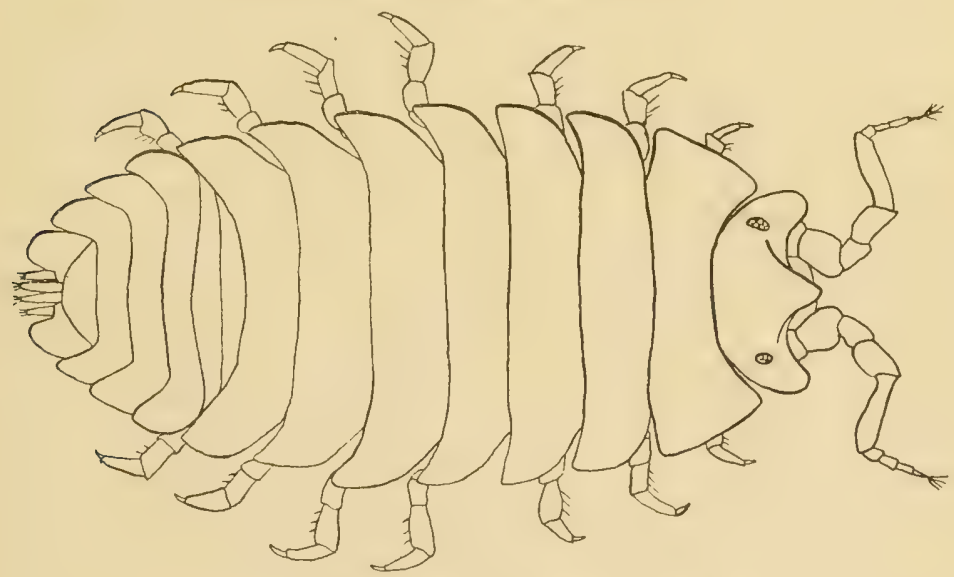

FIG. 83. Actoniscus cllipticus.

I878. Actoniscus cllipticus, Harger, Amer. Jour. Sci., ser. 3, vol. I 5, p. 373 .

I905. Actoniscus cllipticus, Richardson, Bull. U. S. Nat. ior I878, p. 309, pl. I, fig. 3 . 
1115. Aituniscus illipticus, Richardson, Bull. U. S. Nat. Mus., No. 54, p. 634 .

Indy rather broadly ural and depressed, twice as long as wide. Head broader in front than behind with antero-lateral angle: proluced in broad, diverging, rounded lobes, angularly produced in midelle line beyond lateral lobes. Eyes small, black, oval, situated at sides of median triangular process.

Antenne with first joint short; second joint enlarged distally, cifecially on inner side; third joint scarcely as long as second, clavate, and articulated at an angle with the preceding one; fourth joint longer than third; fifth still longer, slender, slightly bent at the base and so forming an angle with the fourth; flagellum shorter than last joint of peduncle, composed of four joints of which the second and the third are longer than the first which in turn is longer than the fourth; terminal segment showing indications of another rudimentary segment and tipped with setæ.

First thoracic segment excavated in front for the accommodation of the head: sicceeding segments subequal to the seventh which is the shortest; first segment prolonged laterally to about twice its length on the nuid-dorsal line; the second and in an inereating degree, the suceeding seoments, produced backwards at the siles. I eegs rather small and weak and of uniform size, ambulatory.

Auteniln with first two semments having their lateral lamelle wimetete and concealed ly the serenth thoracic segment; third, fommh, and hifh sements produced laterally into broad plates which ate ctowed hackwarls, and whose margins continue the cren contour of the thorax; last segnent not as long as wide, rommlel puteriorly. Lropuds terminal with peduncles which are expmelerl on that they continue the contontr of the body and are larger than the expansions of the fifth segment; ramus styliform and tipled with setat inner pair arising irom near the base of the perluncles and extending very slightly beyond the outer ones which arise from a notch near the mirldle of the inner margin of the pertuncle and surpass slightly the expanded lobe of the peduncle.

Color, slaty gray.

Length $4 \mathrm{~mm}$. 
This species has been found at Savin Rock, near New Haven, and Stony Creek, Connecticut, in company with Philoscia vittata Say, by Professor Verrill.

\section{ARMADILLIDID压.}

Body convex, contractile into a ball.

Antennæ comparatively small, with flagellum bi-or triarticulate.

Head flanked by side plates of first thoracic segment, front margin subtruncate, lateral lobes distinct; median lobe obsolete; epistome vertical. Mouth parts similar in structure to those of the Oniscidx.

Legs comparatively short and uniform in structure, ambulatory.

Abdomen not abruptly contracted. Terminal segment short and broad. Opercular plates of first two pairs of pleopods, or of all five pairs, provided with air spaces. Uropods short, not extending beyond the limits of the last segment and lateral plates of the fifth segment.

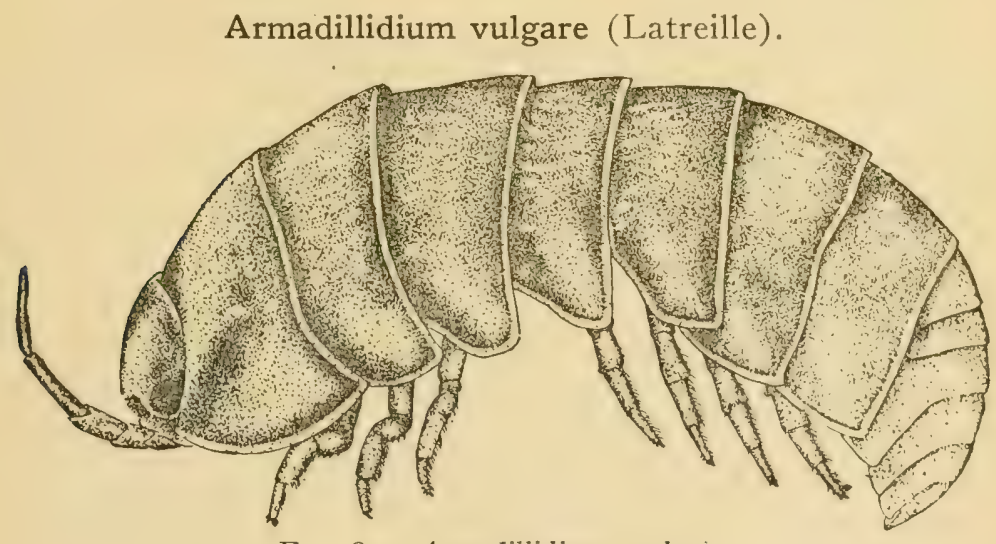

FIG. 84. Armadillidium vulgare.

I818. Armadillo pitularis, Say, Jour. Acad. Nat. Sci. Phila., vol. I, p. 432 .

I84I. Armadillo pitularis, Gould, Invert. Mass., p. 336.

1899. Armadillidium vulgare, G. O. Sars, Crust. Norway, vol. 2 , p. 189, pl. 82 . 
In)5. Armadillidium i'ulgare, Kichardson, Bull. U. S. Nat. Mus., No. 54, p. 666.

1(x) 5. Armudillidium z'ulgare, I'aulmier, Bull. N. Y. State Mus., No. 91, p. I84.

limly ohlong-ovate with lateral margins subparallel, rather convex and able to be rolled up into a ball; twice as long as wide; aldement one-lifth the length of the body. Ilead much wider than lons. transiersely truncated in front with lateral lobes small and rounded. Lyes small, round, compound, and situated laterally.

first anlenne rudimentary and inconspicuous. Second pair one-fourth ats long as body; second joint four times as long as first: third joint one-half as long as second and shorter than the intrth joint which is one-half as long as the fifth; flagelium as long at tifth joint, composed of two joints of which the first is the shorter.

Theracic sements subequal, coxal plates not distinct, those of the first sument with posterior angle acute. Last pair of legs with ischimm large but not, in accordance with Sars's description, as long as the succeeding joints.

Whlomen semicircular, as wide as thorax; first two segments covererl at the sides by the serenth thoracic segment. Last segment much shorter than wide at the base, slightly tapering distally, tip transiersuly truncated. Cropods not longer than terminal segment of aldomen: outer ramus much shorter than peduncle, which is not visible from above, and very broad; inner ramus narrow and chungate, not extending beyond extremity of abdomen.

cilor, sometines miformly darl grey or nearly black, sometimes variegated with lighter patches.

Length $16 \mathrm{~mm}$.

Distribution: world wide; Algeria; Azores; Bermuda; Inuiciana: Texas: Missisiprit; Kentucly: Washington, District of Columbia; Sotth Carolina: New Iork; Long Island; ()hio: Matsachusets; Rhole Island; New Haven, Connecticut.

This species is found under stones; in cellars; under boards in damp soil; in hothouses. It is injurious to some plants grown in errecuhnuse's as well as to youmg cotton and mushronms in Louisiana and Texas. 
It can be distinguished from other terrestrial forms by the short uropods which do not project behind the telson which is truncate.

\section{SCYPHACID无.}

Head without median or antero-lateral lobes. Front not margined but continuous with the epistome.

Second pair of antennæ with flagellum composed of four joints.

Mandibles without molar tubercle. First maxillæ with inner lobe furnished with two plumose setæ; outer lobe furnished with teeth. Maxillipeds with masticatory lobe acutely produced; palp elongate.

Abdomen not abruptly contracted. Uropods extending beyond tip of abdomen; inner ramus inserted at upper inner margin of peduncle.

\section{Scyphacella arenicola Smith.}

I874. Scyphacclla arcnicola, Smith, Rept. U. S. Com. Fish. for $187 \mathrm{I}-2$, , p. 568.

I880. Scyphacella arenicola, Harger, ibid., for 1878, p. 307, pl. I, fig. 2 .

Ig05. Scyphacella arenicola, Richardson, Bull. U. S. Nat. Mus., No. 54, p. 67 I.

As I have not met with this species myself I quote Professor Smith's original description:

"Body elliptical; abdomen not abruptly narrower than the thorax; the whole dorsal surface, except the extremity of the abdomen, covered with small, depressed tubercles which give rise to minute spinules; eyes prominent, round; antenna a little longer than the breadth of the body; first and second segments short, equal; third, fourth, and fifth successively longer, the fifth being rather longer than the terminal portion, which is more slender than the fifth segment, tapers regularly to the tip, and is composed of three successively much shorter segments, and a very short somewhat spiniform, but obtuse, terminal one; all the segments, except the minute terminal one, scatteringly beset with spinules; legs beset with small spines; the ischial, meral, carpal, and propodal segments subequal; terminal process of the last segment of the abdomen narrow, triangular, with the apex 
slightly rundel, and the dursal surface a little concave; posterior canchil alpentiaces much shorter than the abdomen; rami slightly inequal, the onter stout, spinulose; the inner a little shorter and much more slender."

Colur, in life, nearly white, with chally white spots and scattered, blackish dots arranged irregularly; in specimens preserved in alcohol, dark brown, with the margins of the segments of a lighter brown.

Length 3-4 $\mathrm{mm}$.

1)istrilution: Great Egg Harbor, New Jersey; mouth of Choptatuk River, Maryland; Vineyard Sound, Woods Hole, Massachusetts; Nantucliet. The species has not yet been reported from Connecticut waters, but may be expected inasmuch as it occurs both to the north and south.

According to Professor Smith, it burrows in the sand of beaches just above ordinary high-water mark. 


\section{LIST OF FIGURES}

Fig. I. Details of head and mouth parts in situ of Page.

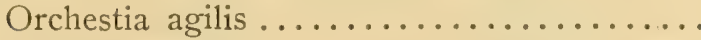

Fig. 2. Internal anatomy of an ideal Gammarid, after Stebbing

Fig. 3. Ideal cross section of a female Gammarid...... 30

Fig. 4. Hyperia galba (Montague)............. 46

Fig. 5. Lysianopsis alba Holmes............. 53

Fig. 6. Tmetonyx quadratus sp. nov............ 56

Fig. 7. Orchomenella pinguis (Boeck); habitus figure after Sars.................... 59

Fig. 8. Ampelisca macrocephala Lilljeborg, after Sars 62

Fig. 9. Ampelisca spinipes Boeck, after Sars......... 64

Fig. Io. Byblis serrata Smith............... 68

Fig. II. Haustorius arenarius (Slabber), after Sars.... 7 I

Fig. 12. Phoxocephalus holbölli (Kröyer), after Sars... 74

Fig. I3. Paraphoxus spinosus Holmes............ 77

Fig. I4. Stenothoe cypris Holmes.............. 79

Fig. I5. Stenothoe minuta Holmes............. 8I

Fig. I6. Sympleustes glaber (Boeck), after Sars..... 85

Fig. I7. Calliopius læviusculus (Kröyer), habitus figure

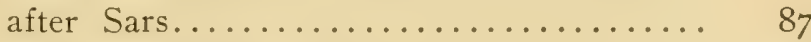

Fig. I8. Batea secunda Holmes............... 89

Fig. 19. Pontogeneia inermis (Kröyer), after Sars... 92

Fig. 20. Eucrangonyx gracilis (Smith)........... 94

Fig. 21. Crangonyx tenuis Smith .............. 96

Fig. 22. Melita nitida Smith................ 99

Fig. 23. Melita dentata (Kröyer), after Sars........ Ior

Fig. 24. Elasmopus levis (Smith) .............. I04

Fig. 25. Dikerogammarus fasciatus (Say).......... I06

Fig. 26. Gammarus locusta (Linnæus), habitus figure after Sars........................ Ios

Fig. 27. Gammarus annulatus Smith............ II

Fig. 28. Gammarus marinus Leach, after Sars....... II2 
[ïg. 21. Carinogammarus mucronatus (Say), habitus

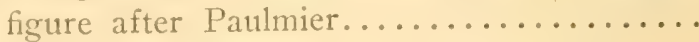

Page.

liis. 30. Dexamine thea Boeck.......................... Orchestia agilis Smith. The upper right hand I I 4 I 16 drawing shows the sperm duct when enlarged

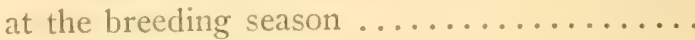

Fiv. 32. Orchestia palustris Smith............... I2 I

Fi. 33. Talorchestia longicornis (Say)............ I23

lik. 3t. Talorchestia megalophthalma (Bate) ........

Iiis. 35. Hyale prevostii (Milne-Edwards), habitus figure after Sits

125

127

Fiis. 35). Hyalella knickerbockeri (Bate), after Smith...

l:ir. 37. Allorchestes littoralis Stimpson, after Paulmier I 31

lï. 3\%. Microdeutopus gryllotalpa Costa, after Sars....

Fi. 31). Lembos smithi (Holmes) ...............

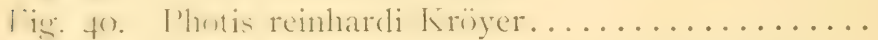

134

I 37

I.j. 41. Podoceropsis nitida (Stimpson), after Sars....

140

I ij... +2. Leptocheirus pinguis (Stimpson) ............ I 42

lig. 4.3. Amphithoe longimana Smith.

145

live. 44. Amphithoe rubricata (Montagu), after Sars...

148

Iin. t5. Grubia compta (Smith)...............

150

I:is. fr. Jassa marmorata Holmes, after Paulmier...... 152

Fì... 4\%. Ischyrocerus anguipes Kröyer, habitus figure after Sars..................... I57

Fic. fis. Cerapus tubularis Say, after Smith.......... I60

Fic. f). Ericthonius brasiliensis (Dana), after Sars... I I64

Fie. 50. Tu(iula irrorata Say................ I66

I…5 5. Siphonocetes smithianus Rathbun.......... I69

li... 5. Corophium cylindricum (Say) ........... I72

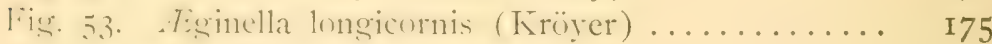

I

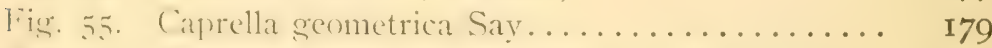

Ti.s. 56. Tanais cavolinii Milne-Edwards, after Sars.... I94

F“.

Fi... - Cyathura carinata (Kröyer), after Harger.... I99

I.i. 5. . Ptilanthura tenuis Harger, after Harger..... 20 I

liir. (x). Cirolana concharum (Stimpson), after Harger 203

I.is. . . . Ega psora (Linnxus), after Harger......... 205

I.j. . ... Egathoa oculata (Say), after Harger........ 208 
Page.

Fig. 63. Livoneca ovalis (Say), after Smith....... 209

Fig. 64. Limnoria lignorum (Rathke), after Harger... 2 I I

Fig. 65. Sphæroma quadridentatum Say, after Harger.. 213

Fig. 66. Chiridotea cœeca (Say), after Harger........ 2I 5

Fig. 67. Chiridotea tuftsii (Stimpson), after Harger.... 217

Fig. 68. Idothea baltica (Pallas), after Harger...... 220

Fig. 69. Idothea phosphorea (Harger), after Harger.... 222

Fig. 7o. Edotea triloba (Say), after Harger......... 224

Fig. 7I. Edotea montosa (Stimpson), after Harger..... 226

Fig. 72. Erichsonella attenuata (Harger), after Harger 227

Fig. 73. Erichsonella filiformis (Say), after Harger.... 229

Fig. 74. Asellus communis Say, after Snith........ 232

Fig. 75. Jæra marina (Fabricius), after Sars........ 234

Fig. 76. Oniscus asellus Linnæus, after Paulmier..... 238

Fig. 77. Philoscia vittata Say, after Harger......... 240

Fig. 78. Cylisticus convexus (DeGeer), after Paulmier 242

Fig. 79. Porcellio spinicornis Say, after Sars........ 243

Fig. 8o. Porcellio scaber Latreille, after Sars........ . .245

Fig. 8I. Porcellio rathkei Brandt, after Paulmier..... 246

Fig. 82. Metoponorthus pruinosus (Brandt), after Paulmier ....................... 248

Fig. 83. Actoniscus ellipticus Harger, after Harger.... 249

Fig. 8+. Armadillidium vulgare (Latreille), after Paulmier................... 25I 


\section{BIBLIOGRAPHY}

Bate, C. S. ()n the Iritish Liriophthalma. Rept. British Soc. for Advance. of Science, I855, pp. I8-62, p1. I 2-22, I 856 .

Catalogue of the Amphipodous Crustacea in the British Musenm, p1. 399, pl. 58, I862.

Bate, C. S. and Westwood, J. O. I I istory of the British Sessile-eyed Crustacea. 2 vols., pp. 507, 536, I 868 .

Bovallius, C. Contributions to a Monograph of the Amphipoda Hyperiidea. Kongliga Svenska. Vetenskaps Akademiens Handlingar, Ny Följd. lid. $2 \mathrm{I}, 110.5$, p. 72 , pls. IO, and Bd. 22, no. 7, pP. 434, pl. IS. I887, I889.

Della Valle, A. Gammarini. Fatuta u. Filora des Golfes von

Neapel, Nonogr. 20, pp. 948, pl. 6r. I893.

Harger, O. Notes on Vew England Isopuda. Proc. U. S.

Nat. Niss, vol. 2, pp. I57-I65. IS80.

Report on the Marine Isopoda of New England.

Rept. U. S. Com. Fish, for I878, pp. 297-462, pls. I-I3. ISSO.

Holmes, S. J. ()hervations on the IJabits and Natural IIistory of Amphithoe longimana Smith. Biol. Bull., vol. 2, Pp. 165-I93. I901.

Synopses of North American Invertebrates, 18. The Amphipoda. Amer. Naturalist, vol. 37, pp. 267-292. I903.

The Amphipoda of Southern New England. Bull. U. S. Bur. Fish., vol. 24, PP. 457-529, pls I-I3. I905.

Judd, S. D. Descriptions of Three Species of Sand Fleas collected at Newport, R. I. Proc. U. S. Nat. Mus., vol. I8, pp. 593-603. I896. 
Kröyer, H. Grönlands Amphipoder. Det Kongelige Danske Videnskabernes Selskabs naturv. og math. Afhandlinger, Afh. 7, pp. 229-326. I 838. Copenhagen.

Kunkel, B. W. The Amphipoda of Bermuda. Trans. Conn. Acad. Arts and Sci., vol. I6, pp. I-I I6. I9Io.

Leidig, F. Ueber Amphipoden und Isopoden. Zeitsch. f. wissen. Zool., Bd. 30 (suppl.), pp. 225-274, pls. 9-12. I 878 .

Mayer, P. Caprelliden. Fauna u. Flora des Golfes von Neapel, Monogr. 6, p. 20I, pls. IO. I882.

Nachtrag zu den Caprelliden, ibid., Monogr. I 7, pp. I 55, pls. 7 . I 890 .

Paulmier, F. C. Iligher Crustacea of New York City. Bull. New York State Museum, no. 9I, pp. IIS-IS9. I905.

Rathbun, Mary J. List of the Crustacea, Fauna of New England, no. 5. Occasional Papers, Boston Society of Natural History, vol. 7, pp. 34-79. I905.

Richardson, Harriet Synopses of North American Invertebrates, 8. The Isopoda. Amer. Naturalist, vol. 34, pp. 207-230, 295-309. I900.

Key to the Isopods of the Atlantic Coast of North America. Proc. U. S. Nat. Mus., vol. 23. pp. 493-579. I90I.

Contributions to the Natural History of the Isopoda. ibid., vol, 27, pp. I-3I. Ig04.

The Isopods of North America. Bull. U. S. Nat. Mus., no. 54, p. 727. I905.

Sars, G. O. Norwegian North Atlantic Expedition 1876.8, vol. 6, pp. 64-223, pls. 7-18. 1885 .

An Account of the Crustacea of Norway, Amphipoda, vol. I, pp. 7 II, pls. 240, suppl. 8, I895. Isopoda, vol. 2, pp. 270, pls. Ioo, suppl. 4. I899.

Say, Thomas An account of the Crustacea of the United States. Jour. Acad. Nat. Sci., Phila., vol. I, pp. 374-40I, 323-433. I8I8. 
Smallwood, M. E. 'The linach lilua, Talorchestia longicornis. Cold Spring Harbor Monogr. I, pp. 27, pls. 3. 1903 .

The Salt-marsh Amphipod, Orchestia palustris. ibid., III, Pp. 2I, pls. 2. I905.

Smith, S. I. (rustatea of the liresh Viaters of the United States. Rept. U. S. Com. Fish. for I872-3, pp. 637-665. I874.

Occurrence of Chelura terebrans, a Crustacean Destructive to Timber of Submarine Structures, on the Coast of the United States. Proc. U. S. Nat. Mus, vol. 2, pp. 232-235. I879.

On the Amphipodous Genera Cerapus, Unciola, and Lepidactylis. Trans. Conn. Acad. Arts and Sci., vol. 4, pp. 268-284, pl. $2^{\text {a }}$, I88o.

Snith, S. I. and Verrill, A. E. Notice of the Invertebrata Dredged in Lake Superior in $187 \mathrm{I}$ by the U. S. Lake Survey. Amer. Jour. Sci., ser. 3, vol. 2 , Pp. 448-454. I87I.

Simith, S I. and Harger, O. Kenert on the Dredgings in the Region of St. Georges Banks in I872. 'Trans. Conn. Acad. Arts and Sci., vol. 3, pp. I-57, pls. I-S. I 874 .

Spencer, W. B. The I rinary ()ratns of the Amphipola. Quart. Jour. Micro. Sci, ser. 2, vol. 25, pp. I83-I9I, pl. I3. IS85.

Stebbing, T. R. R. The Imphipoda. "Challenger" Reports, vol. 29, pp. I737, pls. 210. I888.

A History of Crustacea. Recent Malacostraca. D. Appleton \& Co., New York, Pp. 466. I 893 .

Amphipoda from Costa Rica. Proc. U. S. Nat. Mus., vol. 26, pp. 925-93I, pls. 6о, бі. 1903 .

Das Tierreich, Lief. '2I, Amphipoda, I Gammaridea, pp. So6. I 906.

Stimpson, Wm. Sympis of the Marine Invertebrata of Grand Manan. Smithson. Contrib. Knowledge, VI., pP. 39-58. I 853 . 
Sumner, F. B., Osburn R. C. and Cole, L. J. A IBiological Survey of the Waters of Woods Hole and Vicinity, Bull. Bur. Fish., vol. 31, pp. 860, 274 charts. I9I3.

Verrill, A. E. Explorations of Casco Bay by the U. S. Fish Commission in I873. Proc. Amer. Asso. Advancement Sci., 1873, pp. 340-395, pls., I-6.

Verrill, A. E., Smith, S. I. and Harger, O. Catalogue of the Animals of Vineyard Sound and the Adjacent Waters. Rept. U. S. Com. Fish. for I87I-2, pp. 295-778, pls. I-38. I874.

Weckel, Ada L. The Freshwater Amphipoda of North America. Proc. U. S. Nat. Mus., vol. 32, pp. 25-58. 1907. 



















ant

101

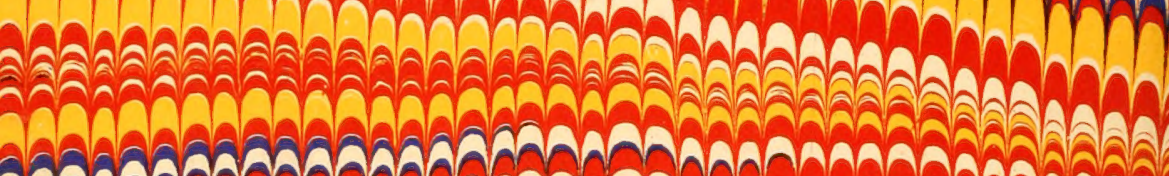

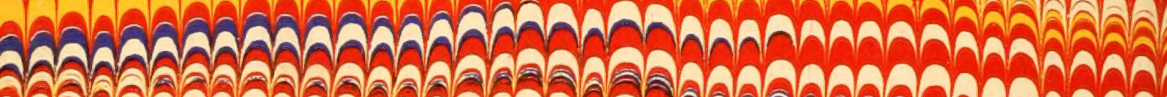

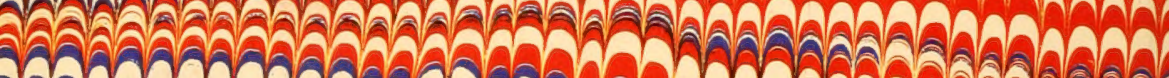

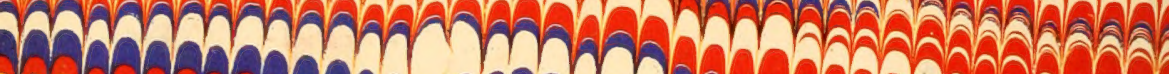

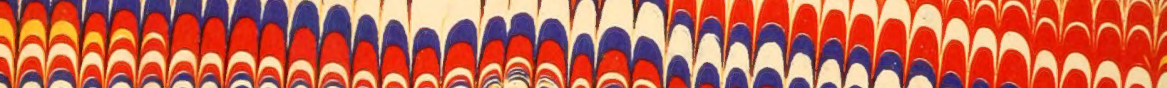

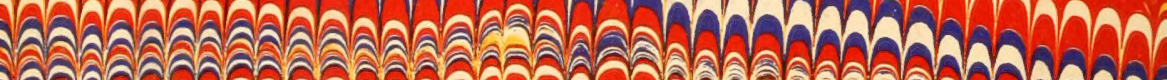

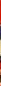
m.mommmma

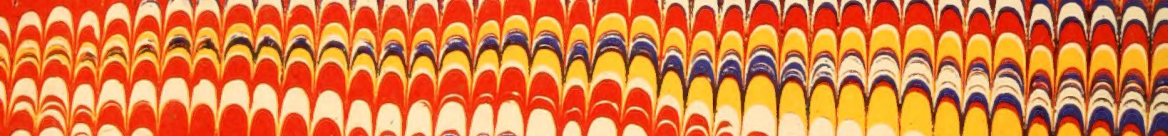

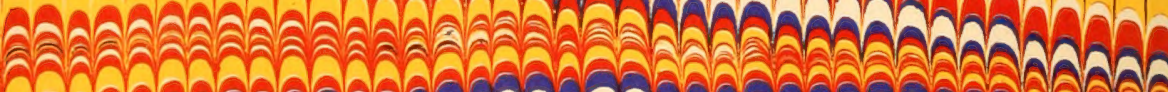

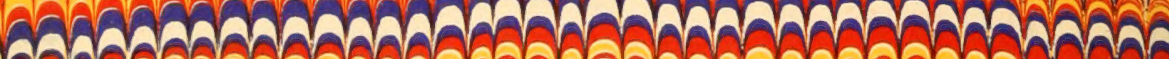

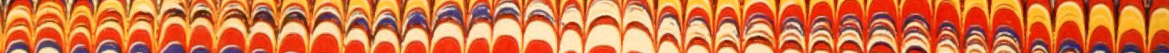

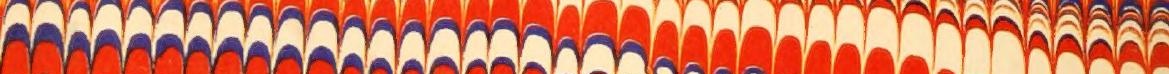
An - -

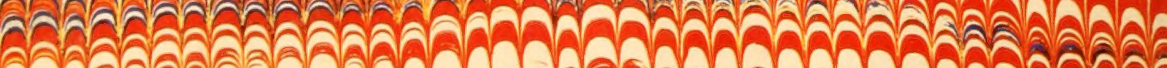
ลลคลคคน

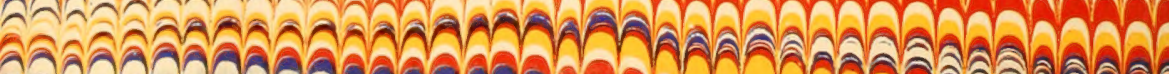

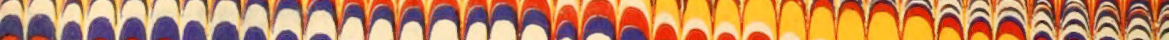


ล. 1.

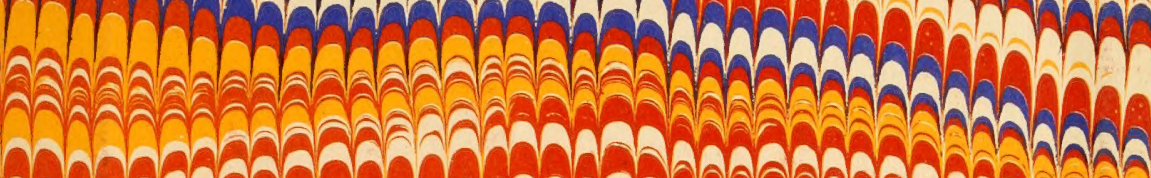

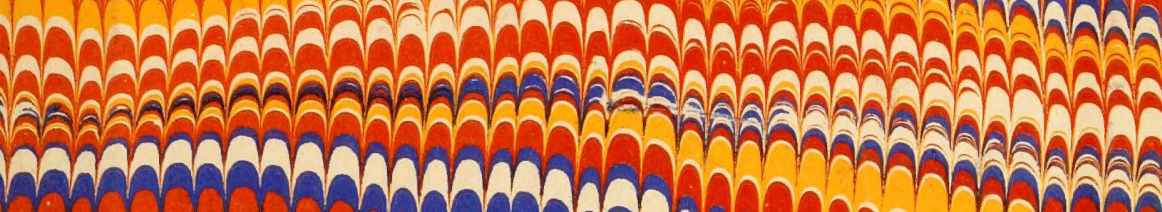

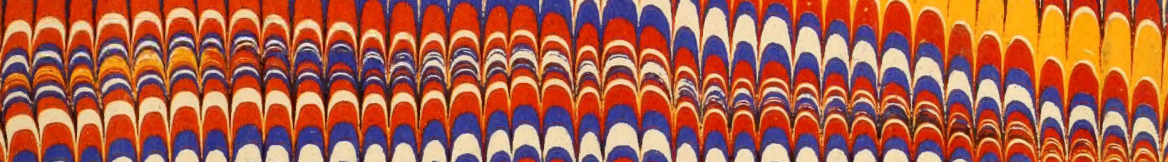
- aล ล2. ล月

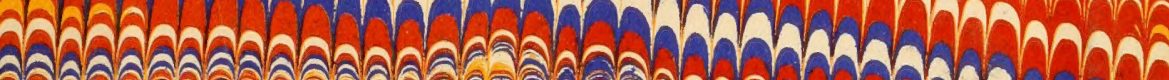

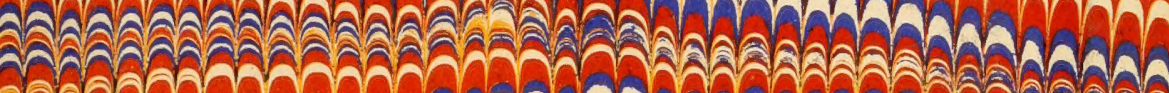
1

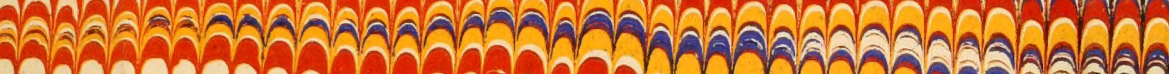
ละล Than

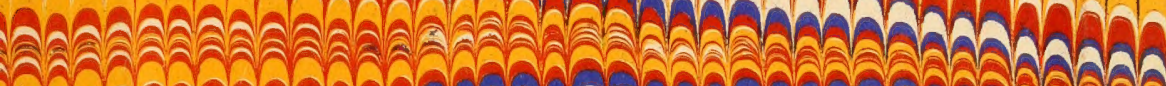

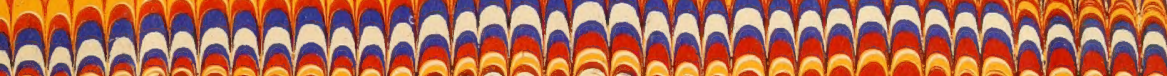

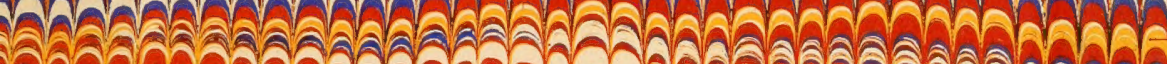

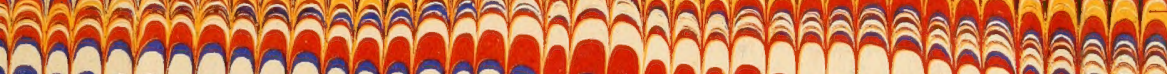

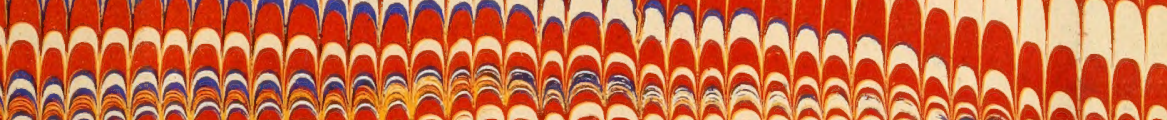

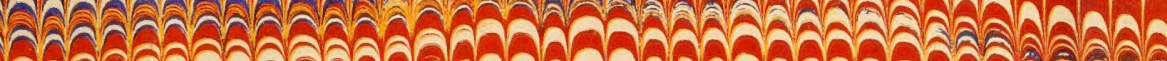

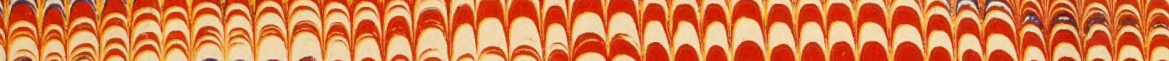


